\title{
SELECTED READING IN AGRICULTURAL APPLICATIONS OF SMALL-FORMAT AERIAL PHOTOGRAPHY
}
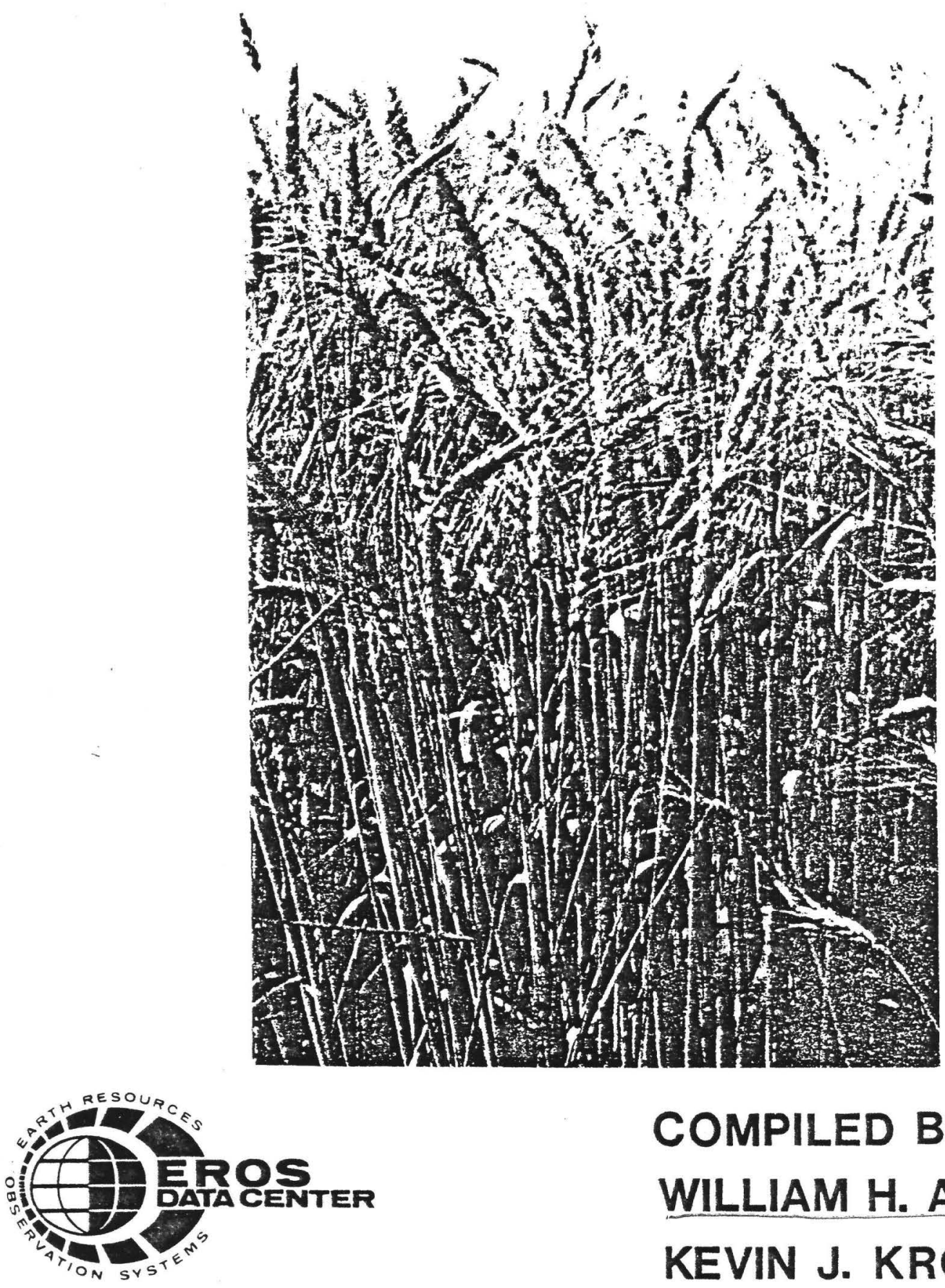

COMPILED BY

WILLIAM H. ANDERSON KEVIN J. KROEGER 


\section{TABLE OF CONTENTS}

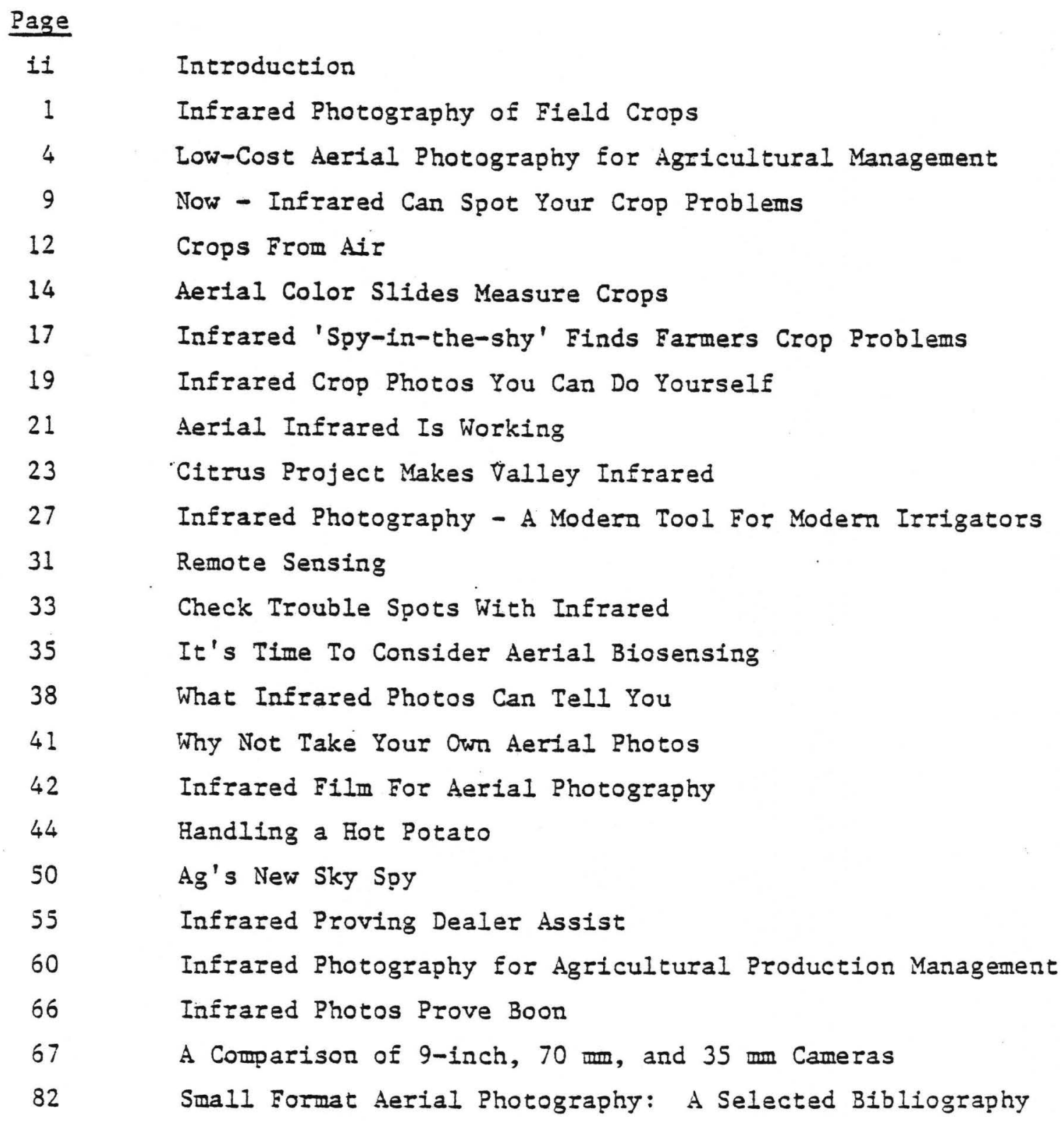

Note: Photographs found in the original articles did not reproduce well in this document due to limitations of the xerox process. They in no way are indicative of the quality of the original illustrations. 


\section{Introduction}

This collection of material has been assembled in response to a growing interest in the use of low-cost, sma11format aerial photography in the management of agricultural resources. Together, these articles serve to document the prevailing level of interest in the subject and provide an insight as to what can reasonably be expected from the use of this powerful agricultural management tool.

William H. Anderson

Applications Scientist, Agriculture EROS Data Center

Sioux Falls, SD 57198

May 25, 1980 


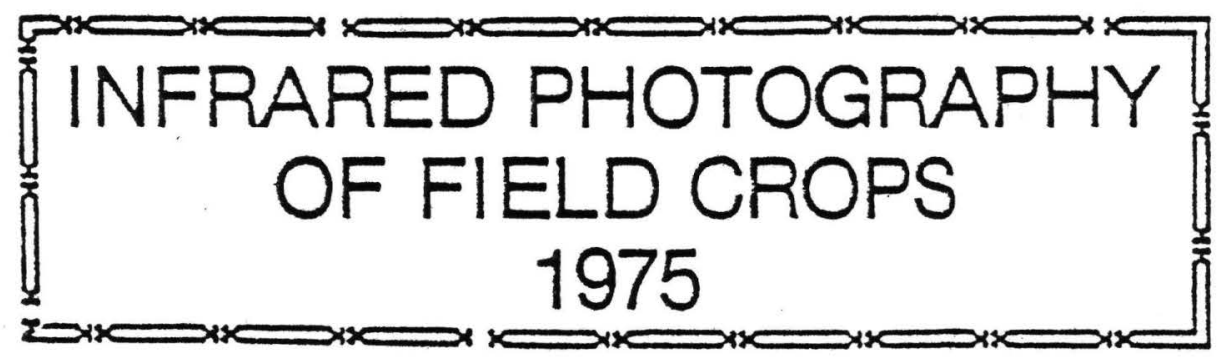

INITIAL PROJECT:

5,000 acres of potato fields

done on weekly basis

PHOTOGRAPHY AND PROJECT CONTROL

Jack C. McKinnon

of

Mckinnon Photo Services

Glenboro, Manitoba Phone 294 


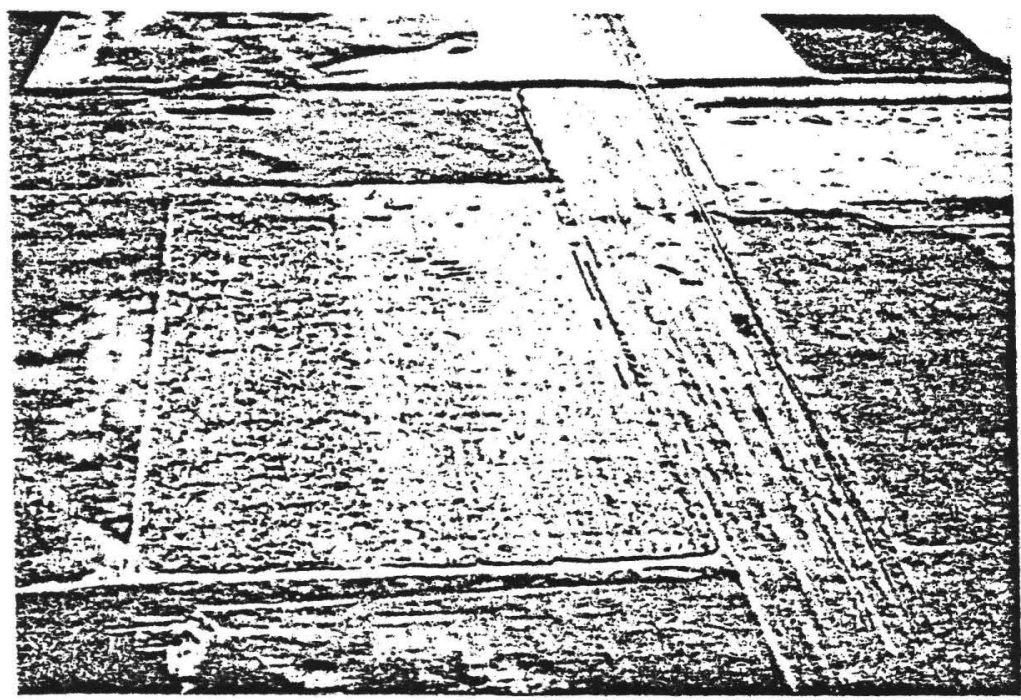

Fig. 5 - Sunflower field. Left half shows heavy stress from Scleratina Wilt. Dark spots illustrate mechanical damage or seeding misses.

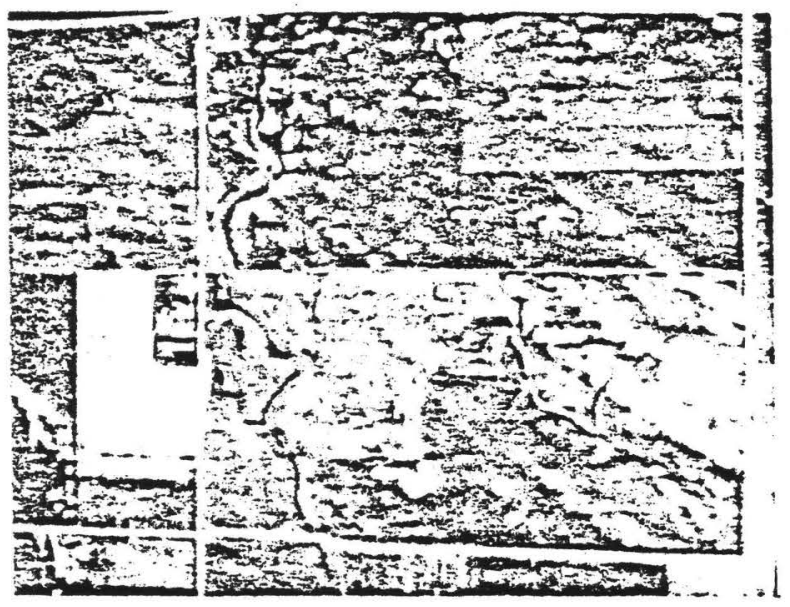

Fig. 6 - A bird's eye view from $\$ 600$ feet, taking in one square mile. Lighter spots indicate shallow top soil.

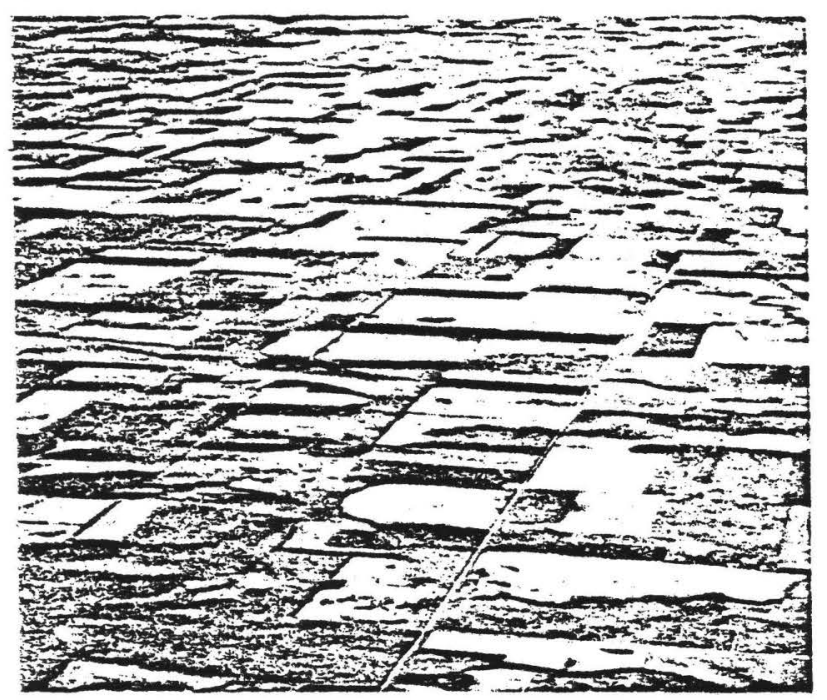

Fig. 7 - Oblique angle from 10,000 feet, taking in several square miles. Shows path of hailstorm in Bruxelles, Manitoda, area.
Processing: The present E.4 system with tanks in a controlled water bath is quite adequate since it will accommodate 200 pictures in one batch. It is absolutely essential that the process be done immediately after the flight. This enables the crop producer to have a very up-to-date service.

Response of Producers: These observations are based on the resuits of a survey and following lengthly discussions with potato growers: That pictures of potato fields should be done every 10 days during growing season. On a normal year June 30th should be the time to begin photography carrying on the 10 day cycle until harvest season which would be early September. This would mean 6.8 separate sessions of photography during the season.

Picture Angle: It was the opinion that more detail was shown from a picture taken straight down as well as more consistant exposure. However, an oblique picture can often encompass more area as well as enabling the viewer to identify the parricular field.

Scale of Photography: Provided that the field was not too elongated it was felt that up to 80 acres in one view would show sufficient detail in the picture. Naturally this scale, approx. $(1: 250,000)$, would not show individual plants but does show areas of discoloration. In order to study seeding misses \& germination var. iation an area of about $j$ acres or less should be included in.one frame.

Late Blight Identification: Since there was no late blight reported in Manitoba during 1975 we have no conclussive evidence. However, we were able to show definite variations within small areas of several fields. The majority of producers have indicated on their surveys that this tecinnique would have illustrated the occurance of late blight.

Commercial Service: Most of the growers involved with the service have indicated that they would like to have this service offered at a commercial level in 1976.

Other benefits to Potato Growers: Again many of these ideas originate with the producer after they studied the photographs.

Soil variations: Due to the difference in reflectance shallow topsoil is clearly indicated. This is due to the fact that clay or sand is often mixed with the loam due to deep tillage practises. Having this knowledge the producer may alter the type or quantiry of fertilizer or he may choose another variety of crop.

Drainage Parems: Since moist soil shows differently the low lying areas can be easily illustrated. This could be invaluable information if one wers investing in an irrigation system. 
The technique of using color infrared aerial photography to detect disease and stress in agricultural crops has been known for some time. In 1967 Frankin E. Manzen of University of Maine clearty illustrated how both color and black and white infrared photography could be used to derect late blight in potato fields. While attending the 1975 annual meeting of Plant Pathologists held in Houston, I was surprised to discover that only a handful of people are actively pursuing this technique. Most of the present efforts of developing this technique for practical use are still based with University research. Consequently, private industry has not yet arisen to the challenge of providing a commercial crop surveillance service using infrared aerial photography.

Our technical research program of 1975 was intended to develop an aerial crop surveillance service in Manitoba. As well as developing the service to a very dependable level it was also necessary to acquaint the producers with the benefits of this program. This often required taking sample views of his fields and helping him to determine the results.

Throughout Manitoba, from Winkler to Porrage to Carberry we undertook to photograph 5.000 acres of potato fields on a weekly basis. The producers who joined the program were required to contribute $\$ 1.00 /$ acre. The rest of the expense was born by a Federal government grant from Energy, Mines and Resources, as well as the business involved, McKinnon Photo, Glenboro, Manitoba.

Following is an outline of some of the technical requirements and data of the pro. gram.

Technical Requirements:

Total Fight Time - 135 hours.

- Aircrart - 140 Cessna

* Pilot - Glen Walleyn (2800 hrs. experience)

*Camera System - Nikon, $35 \mathrm{~mm}$.

*Lenses $-28 \mathrm{~mm}$. $135 \mathrm{~mm}$.

*Film - IE.135-20 Ektachrome Infrared EX.135 Extachrome Color

*Filters - Wratten \#12. Wratten \#15.

* Camera Mount - none - handheid

- Processing - E4 process after flight

Angle of view - vertical, oblique

-Altitude - $300 \mathrm{ft}$. $9600 \mathrm{ft}$.

The aircraft was quite adequate but plans are being made to install a camera mouns to shoot through the bottom of the aircraft. Probabiy a 172 Cessna will be used. The Nikon camera system is quite adequare since it has a motor-driven system; however at times it would be an advantage to have a $70 \mathrm{~mm}$., format. Much more worx needs to be done or film filter combinations.

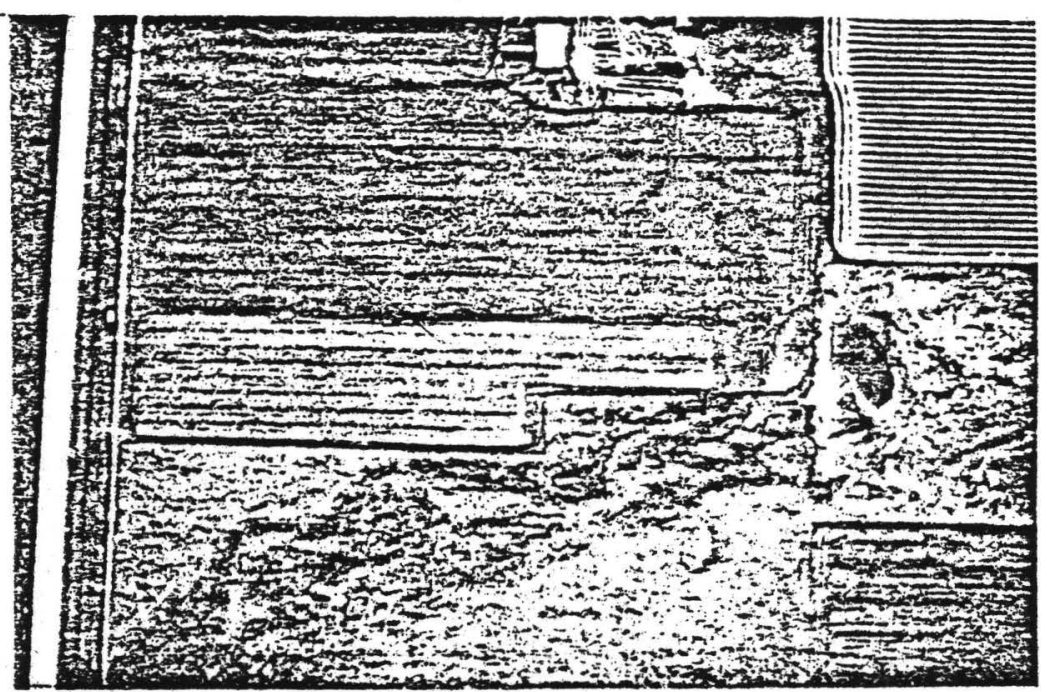

Fig. 2 - Potato fields in Winkler area. Color variation due to different variety. No evidence of stress in either field.

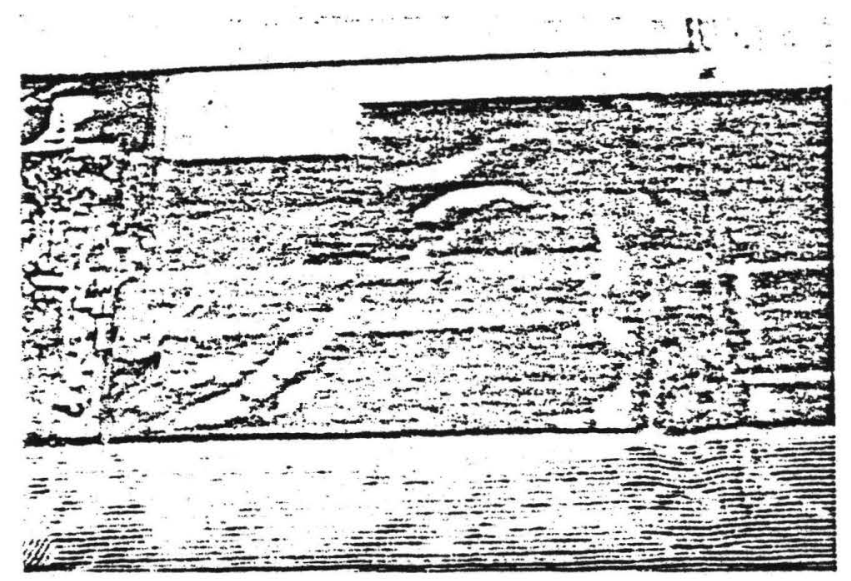

Fig. 3 - Another vertical view of potato fields. Approximately 5000 feet altitude. Notice the 1000 of the ancient river bed resulting in soil variations.

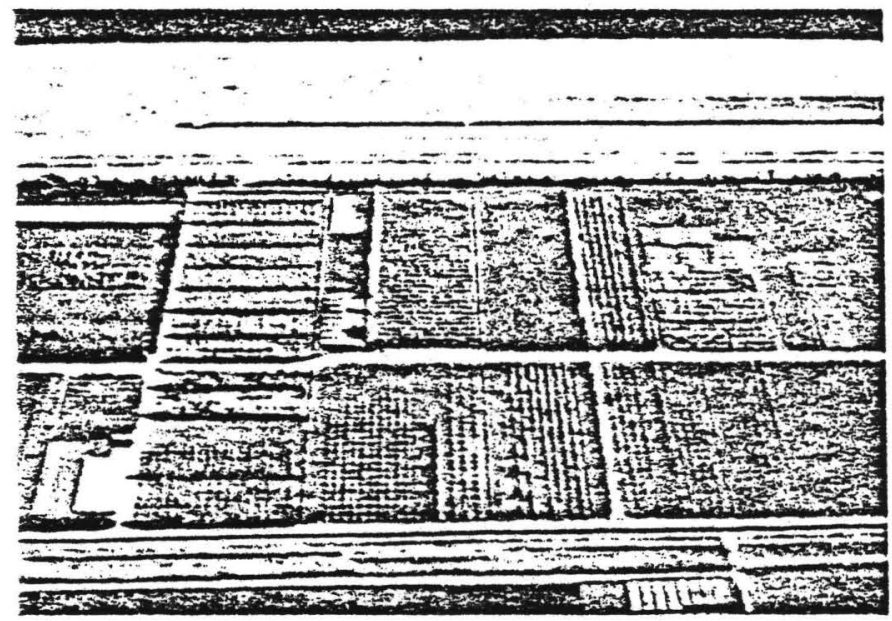

Fig. 4 - Experimental plots at Morden Research Station. An excellent place to try a variety of infrared trials. 
Fig. 1

\section{ACREAGE MEASUREMENT:}

At and altitude of 10,000 feet, using a wide angle lens, one square mile can be included in one frame. Since this material is usually in the form of transparency, it can easily be projected on a chart as shown in Fig. 1. Then one simply counts the number of squares since each one represents one acre. This can greatly add to accuracy in calculating annual yields as well as providing timely information with regard to newly cleared land or amount of a field under water during a flood.

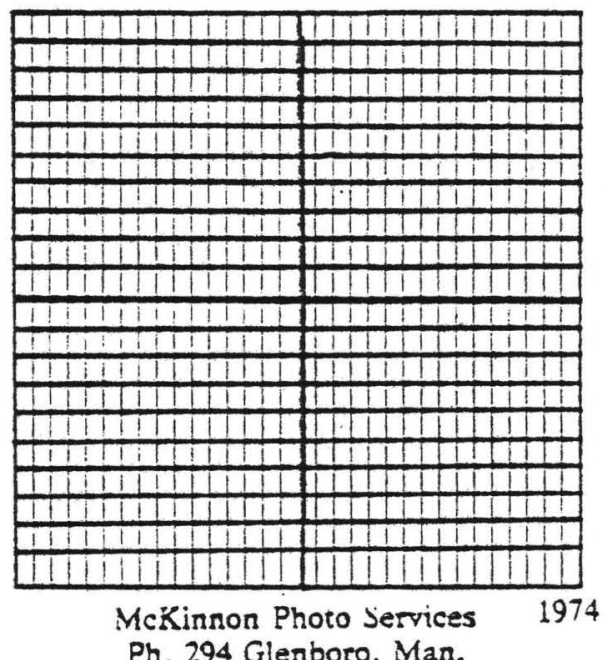

\section{MECHANICAL ERROR WTIH EQULPMENT:}

Since this style of photography provides a clear bird's eye view of all of the fieids it becomes a valuable management tool. Double application of Treflan or Atrazine or missed application of a herbicide stand out very clearly. Uneven seeding practises or damage due to cultivation show quite cleariy. (See Fig. 5). Irregular growth of crops will often indicate soil variations or different practises of land management in the past.

\section{SOURCE OF FARM RECORDS:}

After these pictures have been done regularly, they become an excellent source of accurate records, enabling the manager to compare one year's performance to the next. If used to the fullest extent, this service could prove to be a valuable tool to assist management decisions in this day of more sophisticated methods of agriculture.

\section{FUTURE OF THE SERVICE:}

Anyone today working in this field of Remote Sensing cannot avoid the excitement of the potential in this field of agricultural photography. It is exciting to realize that this technique will become a necessary part of crop management as our agriculture becomes more intensified. It is also fascinating to realize that through these effors, the worid will be better equipped for the critical, increasing demands to feed the growing world population by helping crop production to become more efficient.

However, change does not come easily. It will be many years before the majority of farmers will request this service. In only one narrow field of crop production ie. potatoes, bave we almost reached the level of commercial service. In the numerous other applications which have been suggested 3 lot of furcher experimenting will be required, as well as developing credibility with the potential user. The overall program of 1975 has been moderately successful as far as it has gone. Hopefully, in the years to come, others will join in the effors to develop this very useful tool to be effective in many ocher fieids.

Financially, it would not have been possible to devote the necessary time and energy to this project without the mentioned grant. The Deparment of lndustry and Commerce of the Province of Manitoba have been most encouraging with offers of financial assistance as weil as a considerable amount of technical assistance. Encouragemeat and technical heip were freely given from the many universities, Deparment of Remote Sensing. Ottawa and Manitoba, and many members of Deparments of Agriculture. 


\title{
Low-Cost Aerial Photography For Agricultural Management
}

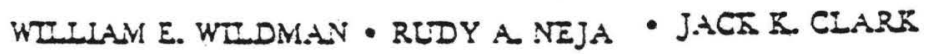

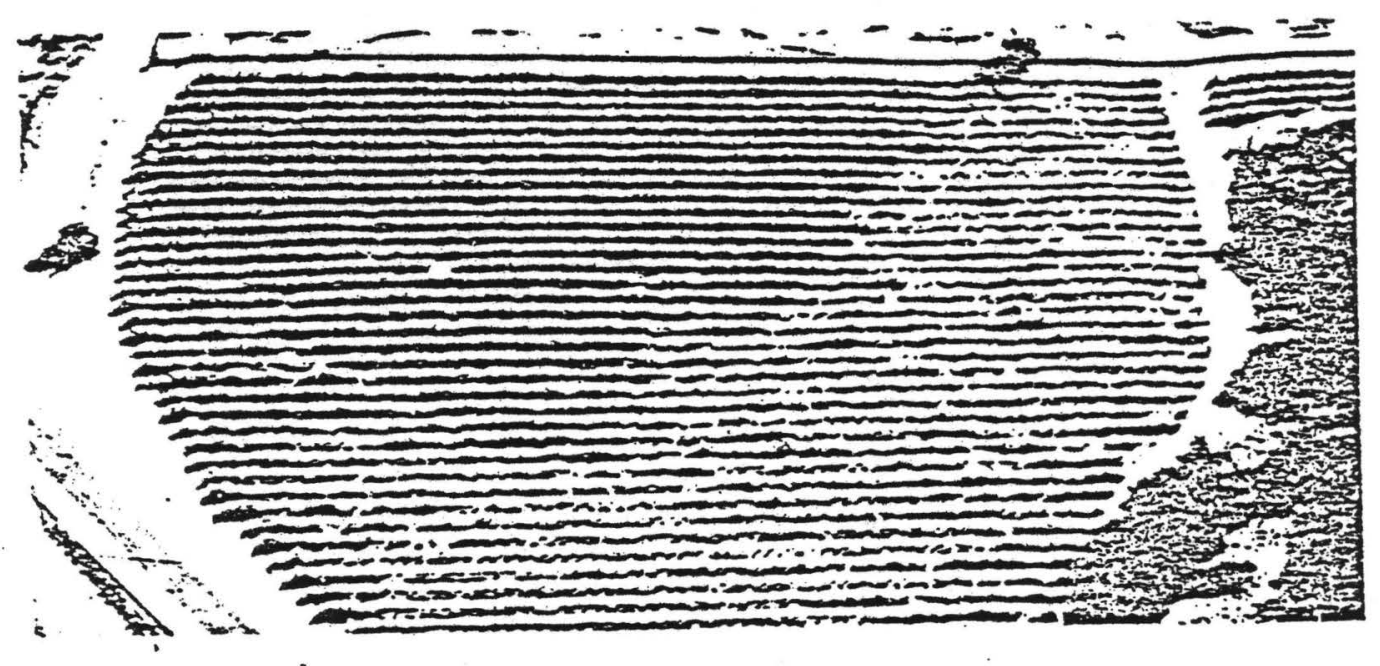

Fig. 1. Uniform irrigation on nonuniform soils guses wide masurity variations. An acditional main line would allow irrigation to maten soii oroperties and procues a more uniform procuce

A ny agricularisi viewiag Califoraia altride must be inopressed by the broad view be gets. Entre Elelds, frorn 10 to $640.2 c r e$ blocks, way be seen in one giance. Reiative thritiness of plants in vatous pars of the Ileid are easily ob served Patterss of rop variation caused oy zouuaifors ierdization, irigation, drinage, saits, soil textre, soil deptb. disease, and insect damage are often more evideat from the air than they are at elose range or the ground. The esonomic sever. iry of the condisons, bowever, must sill be de:erained on the ground by mezsuring sucb factors as plane growet, erop yield, product quairg, and, uldrately, De: resirom

We besame interested in the poten. ia of low-est aecial photograpiny-using reiarively inexpeasive planes and handbeic $35 \mathrm{man}$ easnera-wines it appeared that we could use bis nethod to illusirate radical difierences in zraperise growe eaused by varying joil deptes is vineyards.
After about five years experience, we conclude that aerial photography can be $a$ useful tool in at least the following areas: 1. educatin-; 2. evaiuating land for furste vineyares or orchards; 3. corppining eop histories; 4. monitoring sxperiment. al plots; and j. dizgrosing plant problems.

\section{Educational uses}

Aerial photos of coastal valley vise. yards have been roost usetil in Extension edueational progrars to Illustrate soll and cop variation wittin the sase viseyard block Nonuniform vine growet often eorresponds with varying soli depth or iexure. Aezal phoros emphasize the aOduniformiry, convinang the grower that 2 change in masagenent pracsices in exist. ing risevares stould iaprove vieid and oualisy, and thas soils of future vineyards strould be thoroughty invessigated befor:

Pbotos aixen during the barves: period sinow the greasest contras beeause plandigg. vises that are drying and defolizeing in siallow sol (cover photo) or coarse textured soils (5ig. 1) difier greaty from vises thas saill bave lusin grees folinge growing on deep- of mediurn-iextured soils. Since these contrasting soil deptis or texires can oceur side by side along permaneas sọrniver irrigation rass, large differences in vieid and ousiity otrea result. To optrize producrion ard qual. ify in such viseyards, 3 exange in irigaion management way be sufficient-for sermple, irigzing lighty and frequenty, varying sprinkler nozzle size, or, in exzome eases, plugging the nozzles in arezs of deep soil. Howeve:, is some vineyards, redesigring ine spriakie: systern ray be reapuired to allow blocks of soil to be irigzted separateiy from gready contzst. ing arezs aezriby.

Too often, a grower may have resogrized a probiern from ground obse:vations but let it remain uscorrected beeause be thougint the ares affeered was riagveiy stazil. terial photos of:ea sinow zradations in growith that incieste the problese is more ex:ensive than the growe resilzed. 


\section{Evaluating land for future crops}

A grower considering a permanent crop should carefully examine the poiential site before planting. Aerial photos of bare soil or previous crop growth can show soil variations that should be investigated on the ground by such means as digging backhoe pits. With detailed information on variations in soil depth and texture, the grower is better prepared to plan the layout of blocks of trees or vines to match the most uniform soil areas. He can design irrigation systems to provide the appropriate water application rate and frequency for each individual block. If the soil profile contains shallow compaction or deep restricting layers, he can apply deep tillage or modification treatments before planting that would be difficult or impossible to do after the permanent crop is in. (See tig. 2.)

\section{Crop history}

Growers of certain crops would benefit by having aerial photos taken at least twice annually. The Eirst photos should be taken in early midseason when rop growth is normally vigorous and uni. form. Corrective measures can then be taken if crop nonuniformity is due to variations in irrigation, soil fertility, or pest control.

A second set of photos taken when part of the crop plants are drying up while others remain green usually gives the most informacion about differences in soil waterholding capacity or root damage by soil pachogens. These photos are most useful in determining whether any major operations (deep tillage, fumigation, or changes in management such as irrigation design or scheduling) will significanty im. prove growth in the following years.

Aerial photos taken each year provide a record of crop performance and an be used as a means of improving management practices and justifying their costs. Wistakes made in crop management are often painfully obvious from the air (fig. 3). If the phoros result in improved management, their relatively small cost should be returned many times.

\section{Monitoring experimental plocs}

It is useful to photograph experimental plots from the air periodicaily during the growing season. Our photos of vineyard experiments have provided visual proof that vine growth in plots given a light, frequent irrigation based on tensiometer readings is better controlled than growth in plots given heavy, infrequent irrigations with an early cutoff based on a calendar schedule.

By analyzing infrared photos of experimental plots with sophisticated optical instruments, correlations of plant health with color tone might be developed and used as standards for prediction of commercial crop performance. However, many phorographic and plant growth variables would have to be con. sidered if workable standards were to be developed. (See figs. $43,4 b$, and $4 c$.)

\section{Diagnosing plant problems}

Because most of our photos ivere of known plant problems, we seldon diagnosed the causes solely from the photos. However, as aerial photography comes. into more common use for crop manage. ment, we expect that boch the diagnosing of plant problems and monitoring effects of corrective measures will be increasingly important benefits. Fig. $j$ shows one example in which the photos did pinpoint the cause of irregular vine growth.

The differences between ordinary color and color infrared film are not as dramatic as first expected. But color infrared film often shows visible differences in crops or soils more plainly than color film, and gives clearer pictures because of its greater inherent contrast and haze penetration (because of filtering out of the haze-scattered blue light). If we didn't have the color infrared, we might miss some differences which, though visible, are obscure on color photos.

\section{Taking the photos}

Useful aerial photos can be made using relatively inexpensive cameras and aircraft that are readily available to growers, agribusinesses, and researchers.

We used two $35 \mathrm{~mm}$ single lens reflex cameras, mounted on a singte frame with a pistol grip handle and a double cable release activated by a single plunger. One was loaded with color film, the other with color infrared. They were placed as close together as practicable and were aligned to frame exactly the same scenes. A No. 15 (Wratzen or Tiffen) Eilter on the camera containing the color infrared film Eltered out blue light for a proper color balance. Standard 50 to $5 j \mathrm{~mm}$ lenses were used most often, and the aircraft $w$ as tlown at che altirude required to frame the picture desired; however, for very large ileids and on hazy days, $29 \mathrm{~mm}$ lenses reduced the altitude required for the picture.
At very low altitudes, the apparent speed of the ground can cause bluring, so fast shutter speeds (1/500 or faster) are necessary. On the other hand, very imall Eelds may be more conveniently photographed using a telephoto lens at a higher alitude. Care must be iaken, since any motion of the carrers will be magnified by a relephoto lens.

Exposures for color infrared film are not readily obtained using ordinary light meters. However, a light meter set at ASA $=100 \mathrm{can}$ give a first approximation. Several exposures should be taken at haif and full stop intervals above and below the light meter reading, until one has had some experience with the film and cam. era. Decreases in radiation due to low sun angles or cloudiness make it difficult to estimate the exposure, requiring more than normal bracketing.

Color infrared film does not record heat differences, but is nevertheless subject to damage by high temperatures. Even at normal room temperature, the film dyes change with time. To maintain the most consistent results, the film should be kept frozen until just before use, and then allowed to warm to room temperature before removing from the cannister to avoid condensation of mois. ture. Color infrared film should be exposed within a short period of time, removed from the camera, and refrozen before sending to the processor, if possi. ble, in a styrofoam chest containing cold pactis.

Various light aircraft may be used but some are more convenient thian others. For occasional photograhy where no modification of the aircraft is desired, we ind high.wing planes in which a window can be open wide to be the most versatile.

The procedures outlined will enable almost any agriculturist to take useful photos for crop management. However, commercial or research photographers who require high resolution aerial phocog. raphy should install specially designed aerial camerz equipment in planes modiined for the purpose.

We have just scratched the suriace of possible applications of low-cost aerial photography to asricultural and environmental management. Wuch more research is needed to match the responses of different crops and native joecies with different environmental conditions, and with the resuling characieristic "tone signarures" on color and color inrirared Eims. 
CALIFORNIA AGRICULTURE

APRIL 1975

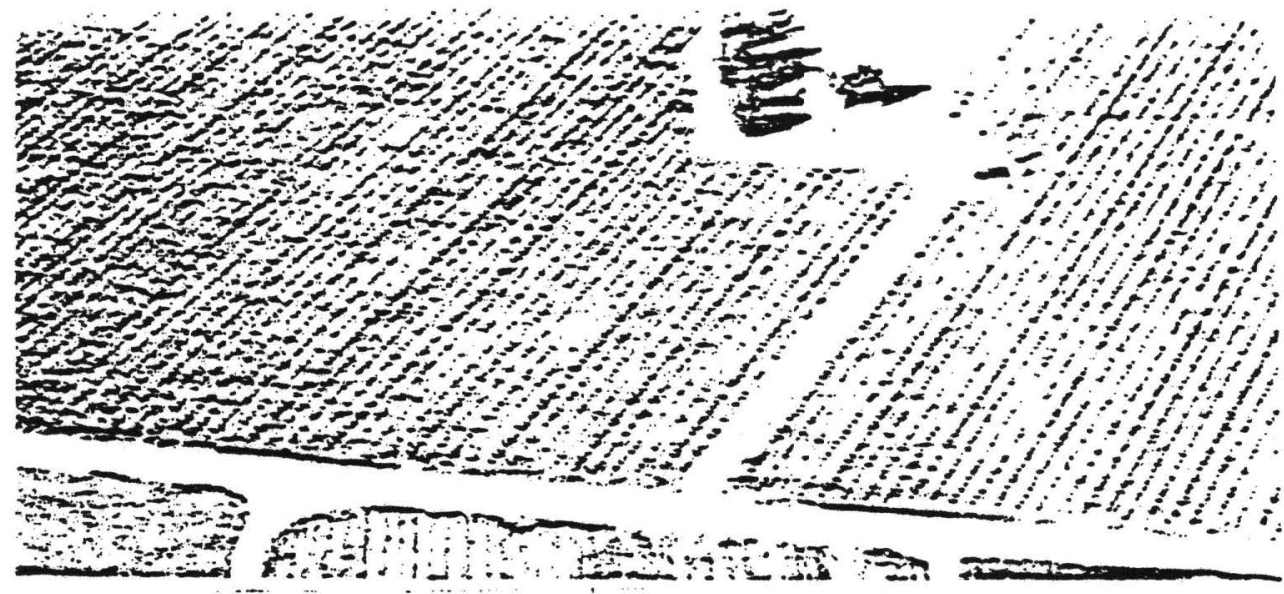

Fig. 2. Trenehing every fourth vine row to placs irrigation pipelines loosened. severely com. pacted soil and produced an unexpected benefit in young vine growth.

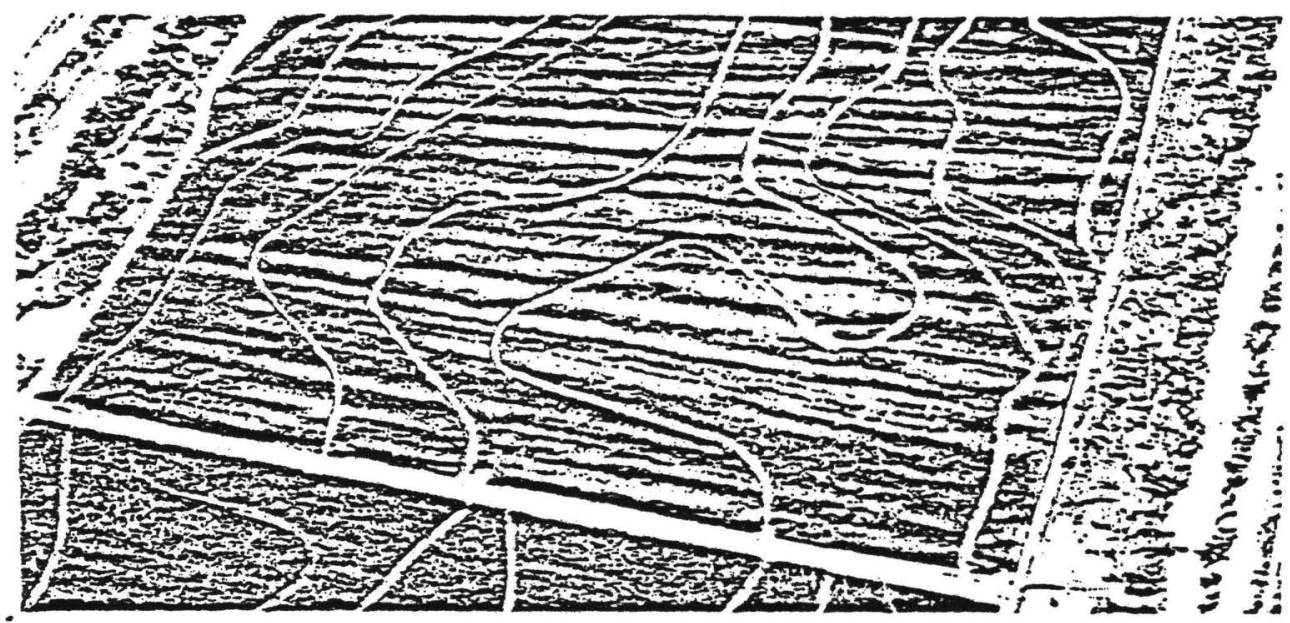

Fig 3. Uneven aoplieation of nitrogen fertilize? on pies is very evident from the air.

We greatly aooreciats suboor of the gerial shoso program by Monteray County Grope Growers Assoc., Saiinas Valley Vinevares. Wence Broiners, Mirassou Vineyarts. Paul Masson Vineyares. Oesidental Chemieal Co., Dow Chemieal Ce., d. G. Boswell Go., and Faather River Mi. Lassen Ciristmas iroe Assoc. Thanks are also due Dr. Philio Langley of Earth Sacellite Cors. for preasing the electronic image ennancement.

Whiam E. Wileman is Extersion Soiis Soecial. 5.. Davis: Ruoy A. Neja is Fim Aovisor for Monterey County: Jack $K$. Clapk is horograenep, Visual Aios. Davis.

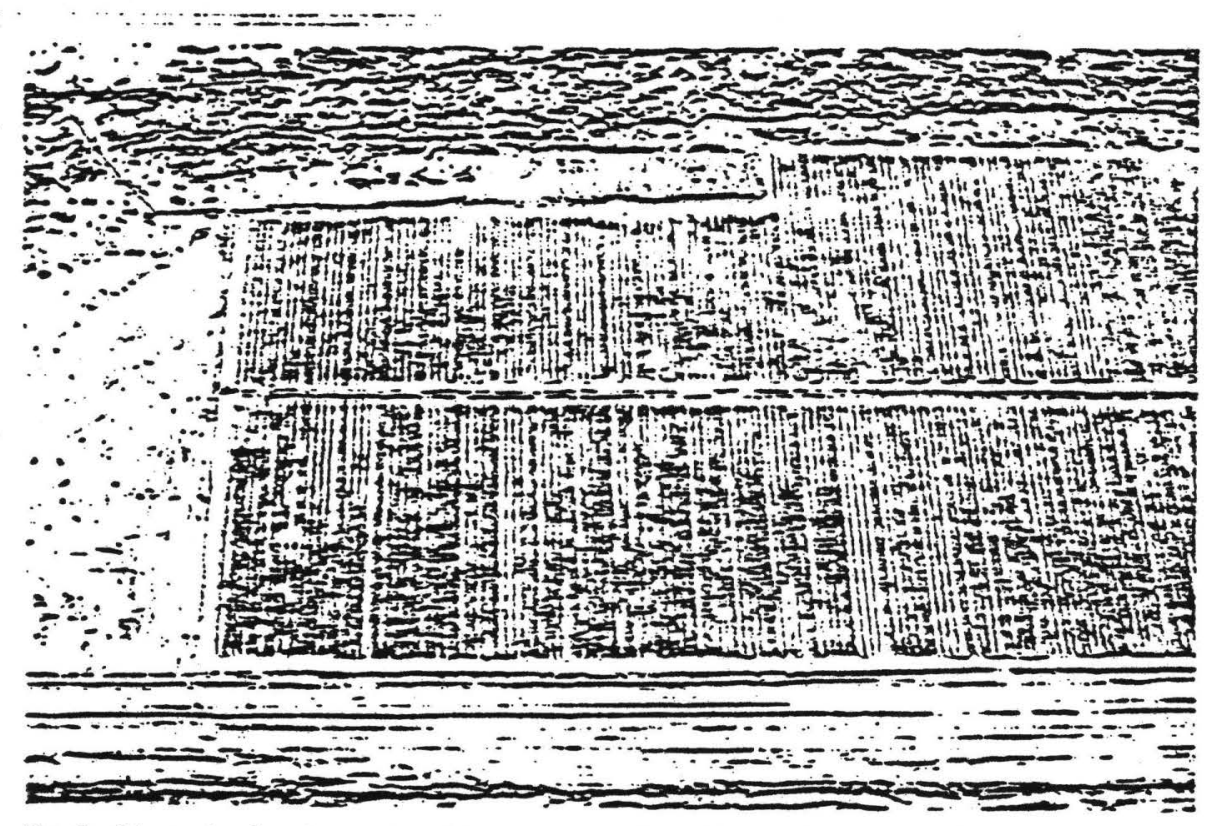

Fig. $\Xi$. Diagnesis of aineyard problem was mace by iakine serial snores a few eavs atrer 11000 irrigation. Smail vines at the ends of the pows correisted with en suriace soils, whice large vines at the centers eortelated with soil inat was still moist at the surtace. Adoarently imoroper leveling allowed most of the water :o inilitrate the centers. 

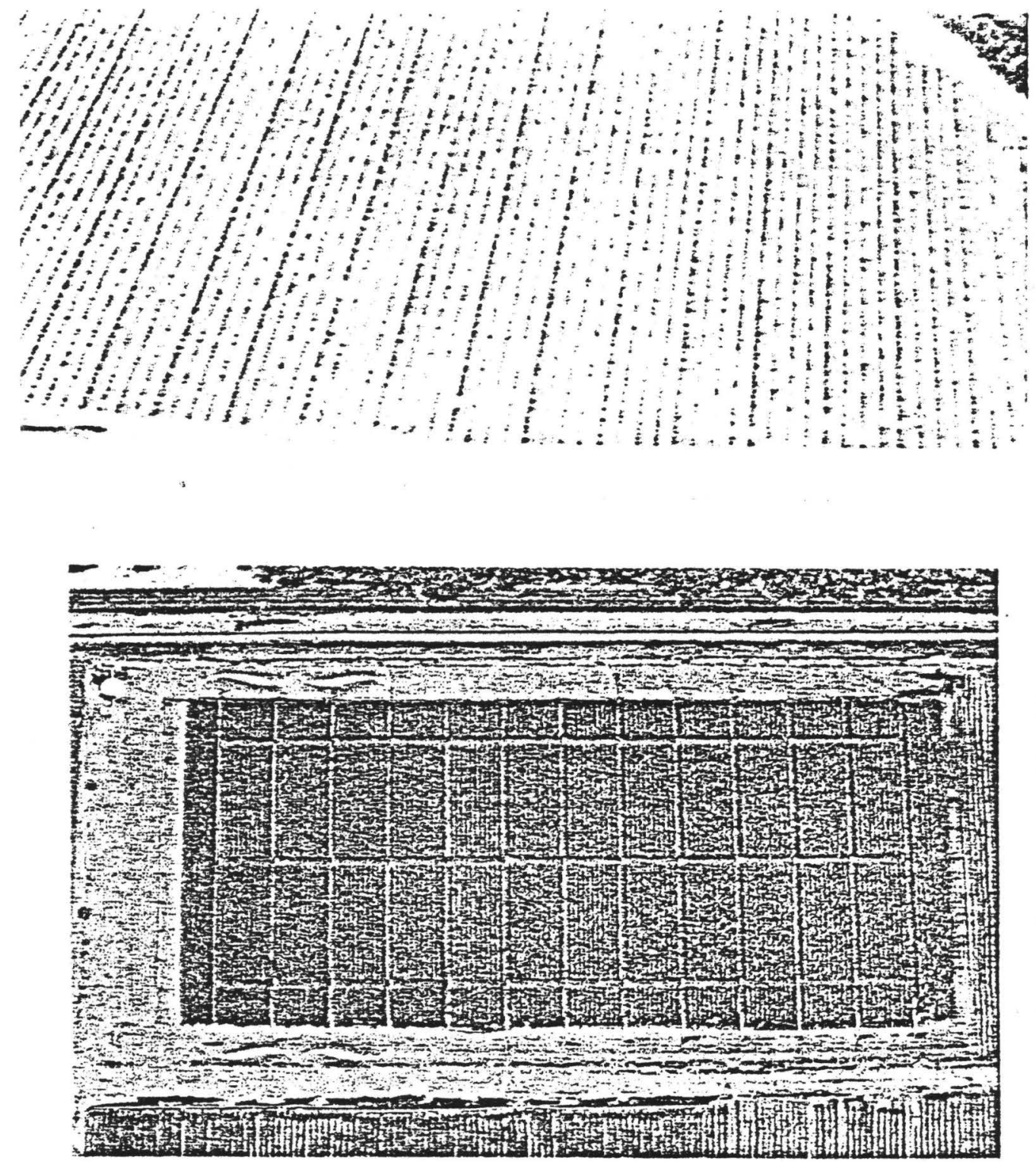

Figs. 4a and 4b. Color infrared photos (leir and righe) of corn experimental plots at the Kearney Horticultural Field Station are superior to ordinary color phocos in differentiating six different leveis of nitrogen fartilization. By analyzing infrared photos with soohisticated instruments, it may

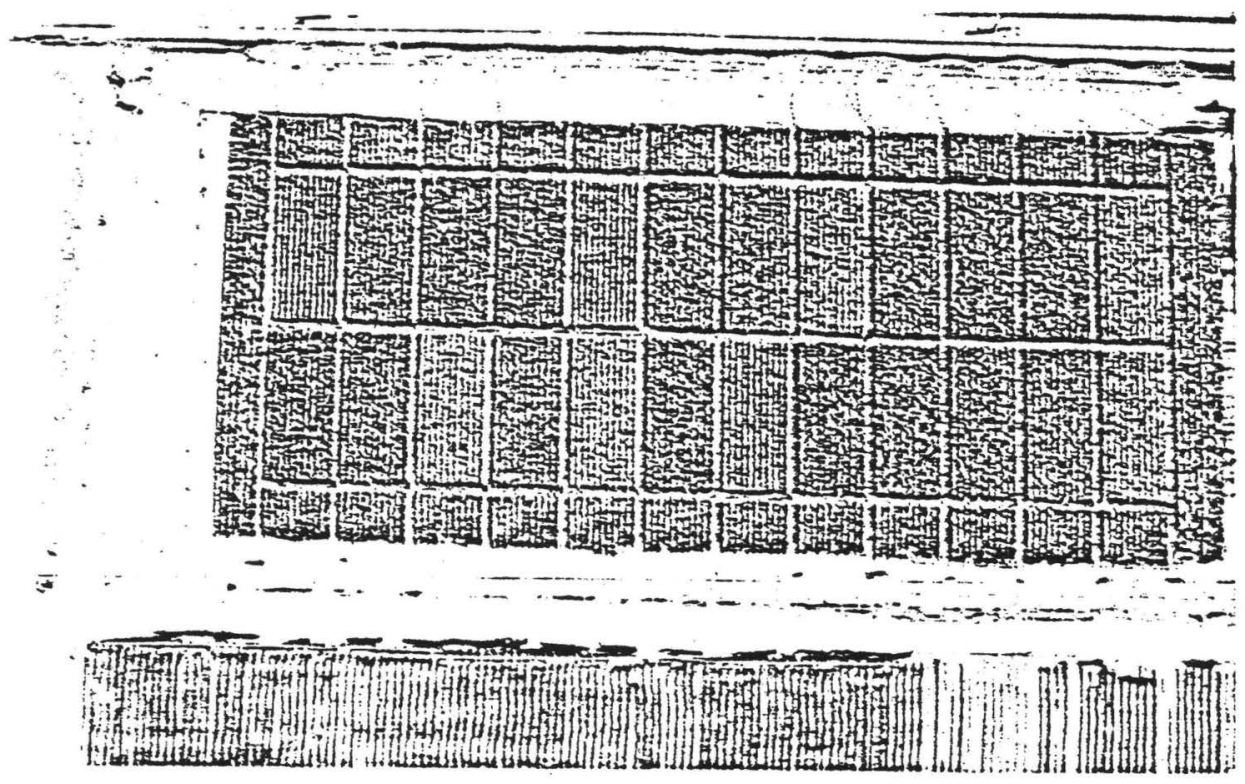

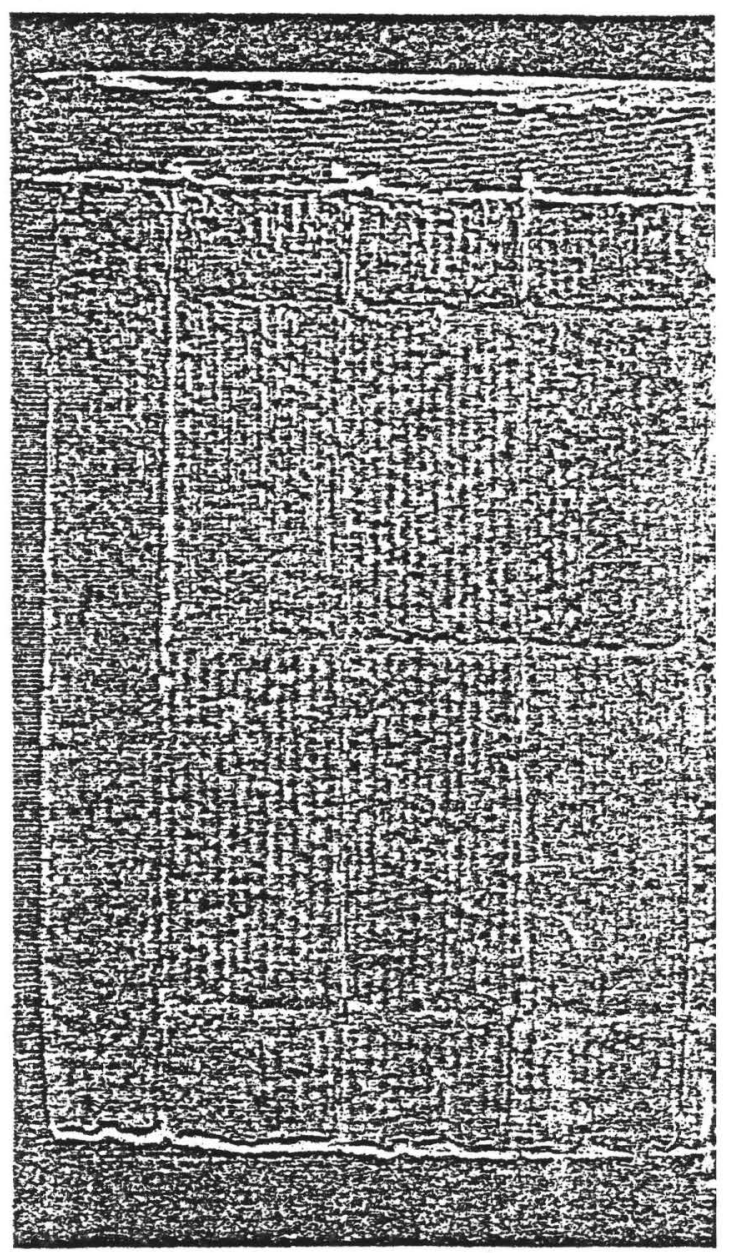

Fig. $4 c$. Slight differences that are undetectabie to the eye may be made visible by electronic image enhancement. Afier electronic image enhancement of iig. $4 a$, all six $N$ levels ara ciearty differentiated.

ce possible so match a particular coior with a certain nitrogen levgl-ootentially a very useful management devica. However, many other variables that affect the color tone would have to be keot constant. 
Crop problems can't hide when airborne photographer captures them on infrared film. Gene Santo (left), fertilizer specialist with High Plains Co-op in Grant, Neb., interprets infrared photos he has taken of uneven millet fields for member Dale Softly (right).

"The stand looked good until we saw it on infrared, " says Rod Fuller (right) of an alfalfa field photographed by Santo (left) "We had some real problems just couldn't see on the ground." Santo's slides help Fuller stay ahead of trouble during the growing season.
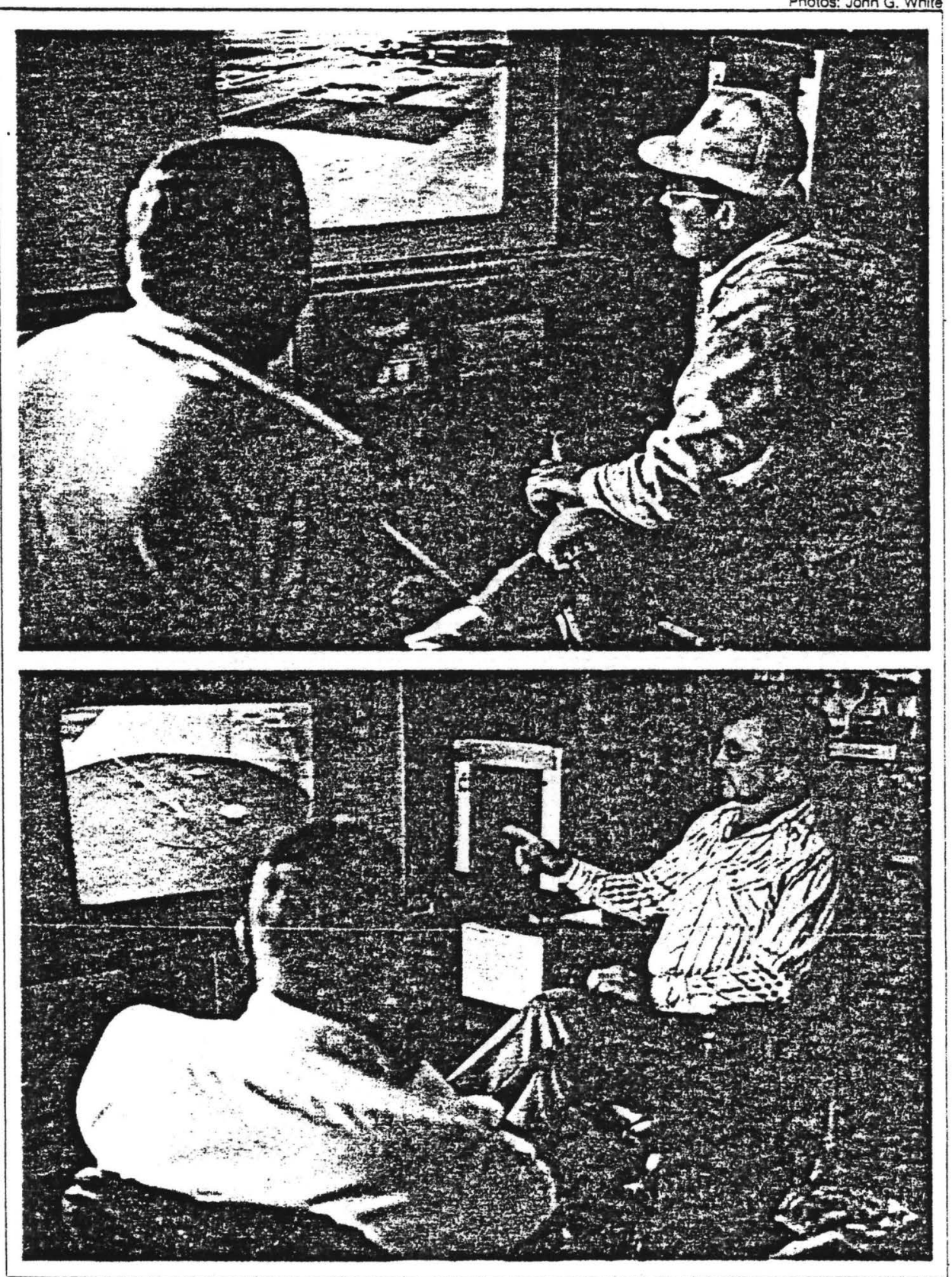

\section{NOW--Infrared can spot your crop problems}

Nitrogen deficiency, drouth damage, weeds-you may think you see everything that's happening to your crop.

But these farmers found out otherwise

BY JOHN G. WHITE

Taken from : The Farm Journal, December, 1976 
G ene Santo reached for the projector switch, and a maze of reds, magentas, pinks and off-greens flashed onto the screen.

"You're getting an uneven distribution of water with this pivot." Santo tells the farmer beside him. "Can you see it? The sprinklers closer to the pivot and the ones out toward the end are putting out a more even supply of water. It's the ones in the middle."

Santo leans toward the screen and points to the affected rows. Now the difference between the lighter and darker reds becomes plain.

"What about the bright pinks?" the farmer asks.

"Those are weeds, but not real serious," Santo says. "It looks like a place the cultivator missed."

Weeds and water are just two of the crop problems which agronomists in the Great Plains are spotting for farmers through the use of infrared photography. They can also detect fertilizer deficiencies, estimate yields, spot disease and insect damage or soil compaction problems. Even the density of Johnsongrass rhizomes lurking beneath the soil surface can be identified with infrared film.

Don't confuse infrared with remote-sensing, heatsensing or other high-altitude survey ideas that have resulted from military and space research. You don't need to put up a satellite for infrared. With a little training, you can learn how to take and interpret the pictures yourself-with a regular $35-\mathrm{mm}$. camera.

When FarM JOURNal looked into it, we found a surprising number of farmers either using or benefiting from infrared photography.

Take Dude Leslie, a Yuma County, Colo., farmer and land developer. Leslie is now flying some 10,000 acres regularly, snapping pictures to learn how to squeeze more production out of every acre.

One of the first things he discovered after comparing normal and infrared pictures of the same center pivot system was the poor distribution he was getting with both water and fertilizer. "We put on threefourths of our $\mathrm{N}$ through the center pivot." he explains. "yet the end gun on one of our old systems was running at $40 \mathrm{lbs}$. pressure while the rest were at the recommended 50 lbs. Not only did this mean poor utilization of our water and fertilizer, but it increased soil compaction," he says.

With another of the 32 center pivots he monitors from the sky, Leslie's films led him to some severely worn nozzles that were putting out 200 more gallons of water per revolution than necessary. His pictures are also helping him learn how to farm some sandy knobs which he was grazing too heavily, disking and planting too deeply but watering too lightly. "There's probably no other area of the U.S. where you can go from a 150-bu. corn field into a 20-bu. field just by crossing the road," Leslie says.

For the farmer with fewer acres, the best bet is to find a custom photographer/interpreter like George Bavless, co-owner of B\&B Aircraft at Sherman, Tex. You'd need to go in with other farmers in your area to get the cost down to manageable size. Bayless charges around $\$ 100$ an hour for a twin-engine Cessna and labor plus $\$ 10$ per photo. But one shot normally covers about 107 acres.

Better yet, see if your co-op or a local dealer in fertilizer or irrigation equipment might be able to provide the service.

That's how Santo, fertilizer specialist for High Plains Co-op in Grant. Neb., got into it. A damage claim against his firm led him to begin reading up on it. He found infrared uses a "false-color" reversal film developed during the war to detect aerial camouflage.

In the case of crops. healthy plant foliage has a high infrared reflectance and appears a bright purplish red on the film. Unhealthy foliage has very little reflectance and shows up a bluish green, almost gray. Badly stressed foliage is more yellow. This loss of reflectance is one of the first detectable changes on stressed foliage. That's why it can be

(Continued on page 37)

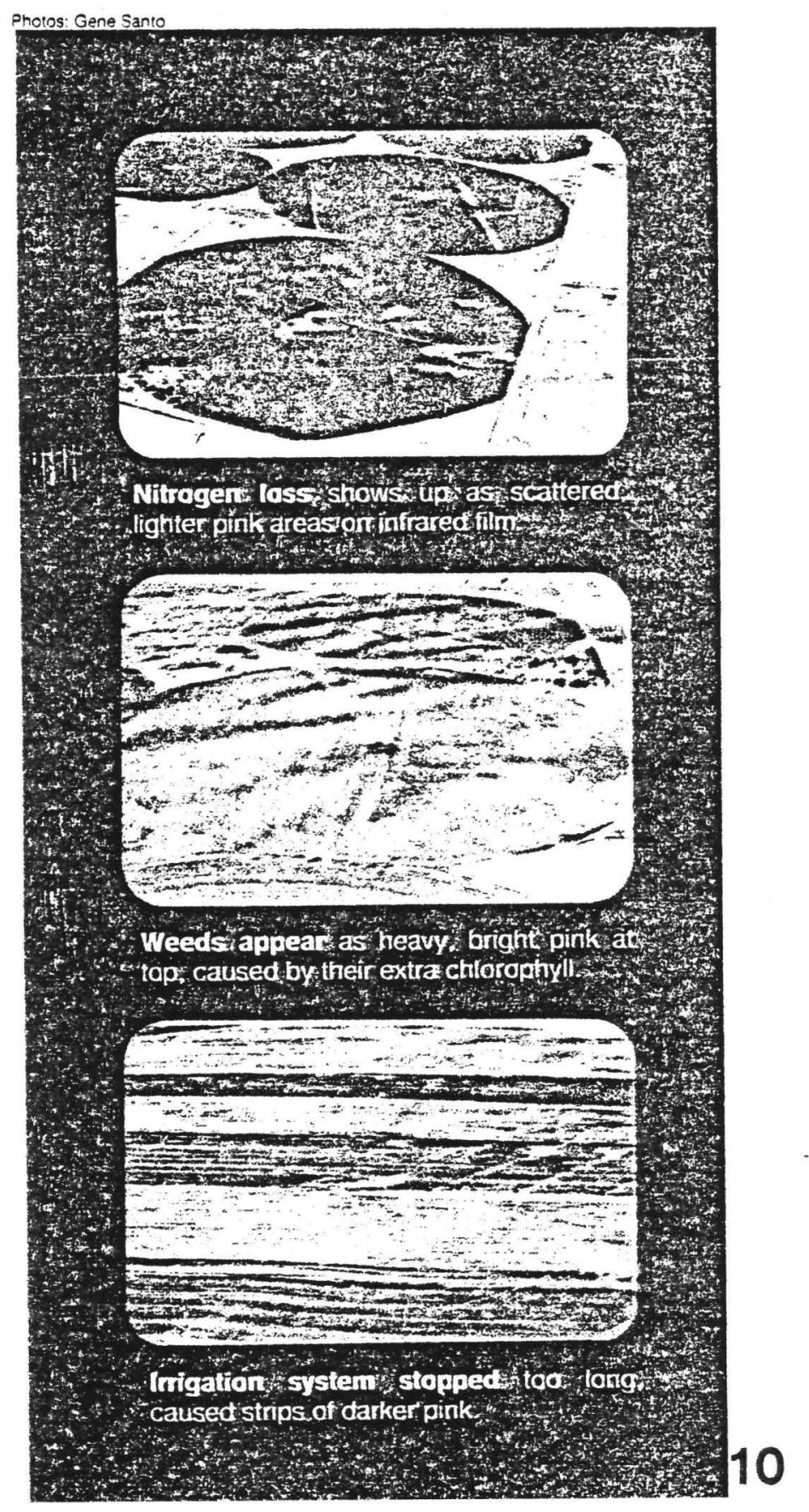




\section{- Nôw ... infrared \\ (Continued from page 19)}

spotted in an infrared photo long be. fore it becomes visible to the eye.

But as Farm Journal reported in February 1974, agronomists are still learning how to "read" the photos. Santo called Kodak in Rochester, N.Y., and the University of Nebras$k a$, but they couldn't offer the help he needed. Their studies had centered mainly around house plants.

"What I needed was an expert from the Vietnam War," S anto says, smiling. Infrared photography was used extensively there to study crop damage from bombing.

So Santo began a careful study of the fields he had photographed. He took his slides, the farmer and the fertilization pian to the field and began piecing the puzzle together. In all, he took 600 soil samples for more than 100 farmers.

He still isn't satisfied-is still try. ing to learn how to detect shortages of other nutrients such as potash. phosphate and sulfur. But he now knows enough that he can look at a slide and give the farmer an idea of his problems.
His customers like the idea even though it's difficult to put an exact dollar figure on its value.

Jim Salsman, who grows 900 acres of com under seven pivot systems, recalls when Santo came to him a year ago with a slide that showed spottiness in a field that had been in sod the previous year. Although the corn was a uniform six" in height, the infrared showed a difference in the nitrogen levels in various parts of the field.

After investigating, Santo and Salsman found where the fertilizer trucks had missed several $25^{\prime}$ to $30^{\circ}$ strips in the field.

"It didn't show when the com came up," Salsman says. "But you could sure see a difference on the infrared film."

Salsman says the field yielded 155 bu. per acre, and he figured that without the correction the yield would have been about 40 bu. per acre less in the untreated areas.

Some farmers like to joln Santo on his flights. "Sometimes I can see something I might be able to correct at once," says Rod Fuller. "Then when the film comes back, I can verify it. The first time I saw one of
Gene's slides of one of my new alfalfa fields, I just couldn't believe it. The stand looked pretty good over all, but we had some problems I just couldn't see on the ground."

It won't cost you much to try the idea out. If you have a cropduster in your area, maybe you can get him to make a couple of sweeps over your place while he's up, with you and your camera aboard.

Santo uses a regular $35-\mathrm{mm}$. camera with a normal $55-\mathrm{mm}$. lens. The film is Kodak Ektachrome infrared film, 80 asa, which should be used with a Wratten 12 filter.

Eariy in the season, Santo concentrates on a tight 60-acre shor, gradually putting more acreage into the picture as the season wears on. S anto recommends Kodak's Applied Infrared Photography Manual (M-29) as a beginning guide.

"With a camera, film and a little footwork on the ground, a farmer can use infrared to real advantage," Santo sums up. "Once you learn to read the results on the film, you can catch some major problems before it is too late. And you won't have to catch many before you've more than paid the expense." 


\section{Lamb County is Using Aerial Photos to Verify Acreage}

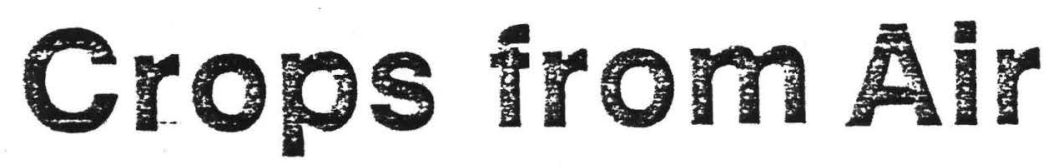

\section{By Nilah Rodgers}

THE ASCS office in Lamb county, on the High Plains, is now using color aerial photographs to measure crop acreages-tirst in the state to move to the new technique.

Practice llights and preliminary work started last September.

Normally, a farmer gays get one crop measured. "Now we chargesIr ror de tris aenatcoion transparency laken anck 3 foreach subsequent picture," said Bil Farris, county ASCS executive director. "The averaze farm requires about five minutes llying time and two pictures. These photos cover every crop on the tarm, too."

"Producer interest is high. We're hoping for 1,000 applications. We tigure it saves at least 50 percent for the farmer. And it represents an 80 percent saving of our time in the office," he said.

"Each photo covers a gunnter sectror a labor of land. Some times, if the fields are laid out right, the obotos cover and xhaltior a labor and a nalf.

"If we can get a quarter-section and another haif, or ail the producer's plots in one photo, we refund the money we charge for a second photo. Say, if a tarmer has three or four crops growing on one labor, where he would pay a $\$ 40$ measurement fee for each different crop, with the aerial photos he'd only pay $\$ 11$ for one photo," Farris said.

The Lamb county ASCS office pays a commercial pilot Aying time and plane rental for the aerial photo lying service. Two ASCS aerial photographers from the Parmer County ASCS office alternate on the photography measurement mis. sions.

Lamb County ASCS compliance supervisor Jake Moreland accompanies the photographers on each of the trips as an observer. He points out the exact location of the place to be photographed for the measurement service.

"We can do a much better job measuring by observing the photos," Farris said. "The exact amount of land for turnrows, low lying areas, terraces, and different crops are readily identifiable."

The plane flies 3500 . w Daxe ground Level Photos are made with a 35 min contor transparencies are put in an over. head projector and the aerial shors are projected below onto the original aerial photograph of that tarm. Adjustments are made until the boundaries on the transparency match up with the farm boundaries on the photograph.

When the slide image matches the scale of the plotted farm map, different crops are drawa off. The office part of the crop measurements work follows the same procedures that bave been used in the past.

"We've just done away with all that time consuming driving and walking around fields, and staking and measuring with chain tapes. The result is more accuracy with tar greater efficiency, yet with a big reduction in time and money," Farris said.

He said there is a vast difference in colors of crops - even related crops like cotton, soybeans and peanuts - which makes it easy to see the crop lines.

"We found out last fall that cotton photographed from 3,500 ft. shows up in hues from bright green to brown to violet," Farris said. The tones change from day to day because of differences in crop maturity and soil conditions.

"This can make it difficult to identify crops from the transparencies. This is the reason we have to have an observer from the office along to certify crop identification. We can do the identification by actual observation.

"Alter three or four hours of practice, the crops in this area can be easily identipied from the air. Last fall we took some photos that showed cotton absolutely lavender. The purplish color was due to the trost changing the leaves and to some of the bolls beginning to open.

"There is a big difference in the retlection of light in plants. Some crops absorb and hold all the light and show up dark. Others radiate light.

"There is quite a contrast, say, between peanuts, cotton and soybeans. And for other crops, even if Ne're not sure what they look ike, we know what they never look like."

Taken from: The Farmer - Stockman, May, 1977 


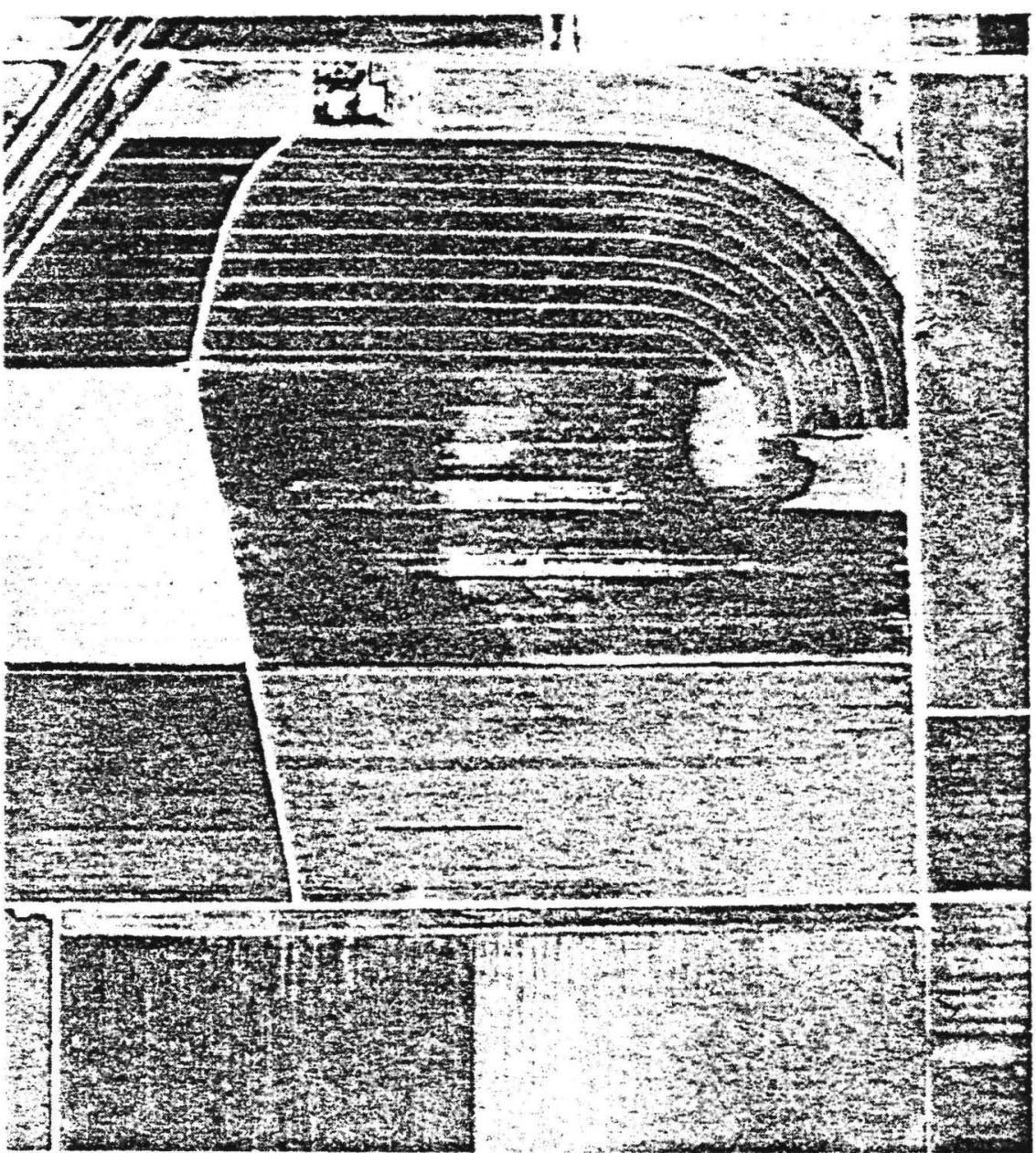

Corn, grain sorghum, wheat and freshly plowed ground can all be picked out from the original color photo of the Scrubb Messamore farm in Lamb county. The unusual pattern near the farmstead is due to certified grain, grown 22 rows in and two rows out for a pollinator.
One of the big pluses for the farmer is that aerial measurements are all guaranteed acreages.

"We stand behind every measurement," Farris said. "So the producer can't get into trouble if an erroneous measurement is made. Our acreage measurements are used for certification."

Farris said they no longer need to guess at the acreage in lakes and terraces. "We can draw them out exactly from the aerial photos, and tell the exact acreage. We can even tell who is farming on whose land.

"In the past we have made three or four measuréments of terraces that might take two and a half or three days. And then we might still be off getting the right measurement.

"Now we can fly it and have everything right in just a few minutes. Even though we are fairly new at this, we can trace a terrace in 15 minutes or less."

Since the aerial measurements are new, Farris said they haven't determined just how long they will keep the photos on file and what other benelits they may be to the producers.

"You can tell many things from the photos," he said. "And they may serve many purposes besides just certifying measurements.

"Last year, in one cotton field we could tell to the row exactly where the farmer had planted grain sorghum the year before. Skips in planting, poor land, heavy rates of fertilizer and other factors show."

Aerial measurements are not new. California has been measuring by air for tour years.

"Before long, all the ASCS offices will be using aerial measurements," Farris said. "Several counties are experimenting with the method now. We just happen to be the first county to go operational.

"Aerial measurements are not something you learn from a text book. It is something ASCS offices have worked out in the interest of accuracy, efficiency, and better service for tarmers," he said.

THE FARMER-STOCKMAN 


\title{
Aerial Color Slides Measure Crops
}

\section{In Coastal Bend Counties-}

\author{
By Keith Guthrie
}

SINTON, Tez. - Aerial color slides, first used in California several years ago and in Lamb County on the High Plains this year, are now being used by the ASCS office in San Patricio County in a crop measuring program that takes in 15 counties in the Coastal Bend.

"We have our aerial mapping program running smooth after getting organized in April of this year," Glenn Drachenberg, executive director of the San Patricio County office said. "Martin Chandler, Parmer County ASCS director, helped us set up our initial program and since that time we have refined the process to our conditions and are now getting excellent results."

The aerial pictures are shot from an altitude of 6,500 to 6,800 feet from ground level with a Cannon $35 \mathrm{~mm}$ camera using a wide angle lens. From this altitude each picture covers a little in excess of one section of land.

\section{Photos Matched}

Aiter the slides have been processed they are projected in the office onto a standard black and white aerial map of the same location, and by the use of a zoom lens on the projector, and by using prominent land marks such as ponds, crossroads, etc., the two photographs are matched up exactly.

Cotton and grain, the two crops being checked in the Coastal Bend area, appear in different

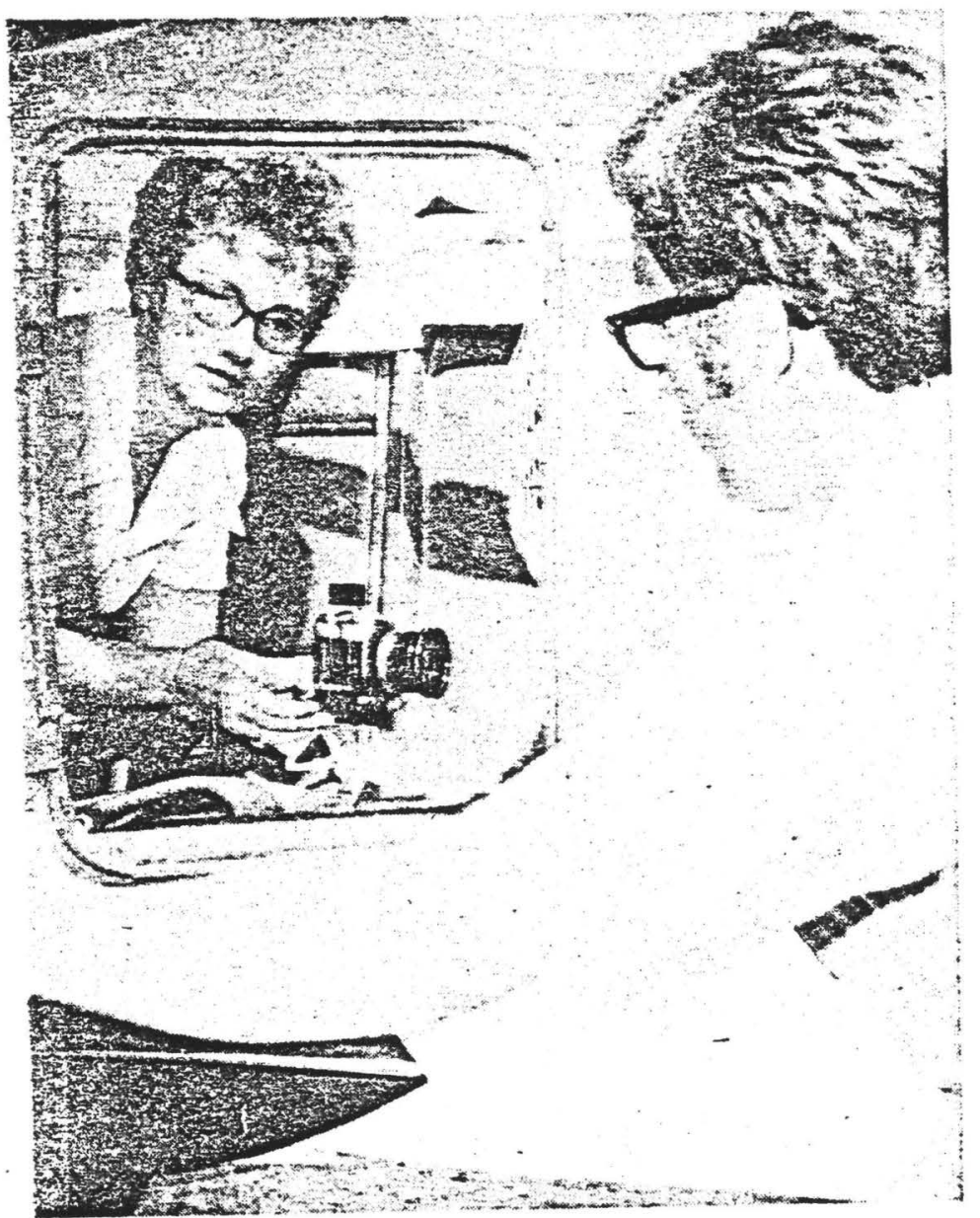

EQUIPMENT CHECX is made by Glenn Drachenberg, San Patricio County ASCS director, through the rear hatch of the plane as Mrs. Hattie Fojtik readies the camera in preparation for a flight to take color slides to be used in acreage checks of cotton and grain in the Coastal Bend region. 
colors on the slides so that an accurate check on the exact acreage planted by each farmer can be determined in a few minutes by the trained technicians in the office.

Hattie Fojtik, a veteran of 18 years in plotting acreages from field notes and aerial maps, heads up the office crew which works up the flight plan from requests, goes along on the flight to help identify the farms and then snaps the photos.

"I have a photo copy of each farm to be photographed along with us on the light," Mrs. Fojtils details, "and as soon as the pilot starts making his run on a selected farm I check for known land marks on the photo copy and then find these in the camera's viewtinder. A second before I snap the picture I check the spirit level on the back of the camera to make sure it is level and then take the picture."

\section{Careful Planning}

The careful planning of the flights in the office before take off has enabled the crew to shoot up to 20 to 25 farms in one flight.

"We are able to do the mapping in one morning that used to take a crew of men on the ground two weeks to accomplish," director Drachenberg said.

At the present time Coastal Bend famens are required to list the acreage that they have planted to grain and cotton. As these reports are filed by the farmers a list is made, and using a preset method of selection they सill photograph approximatel10 percent of the farms in a give: county for checking purposes.

"Ground checking is employed," the director said, "if any question arises." He went on to say that so far the program is being well received by the farmers in San Patricio County.

\section{'Spying' Charged}

"At first the farmers came in to complain that we were 'spying on them' but when we brought them back into the office and showed them our system, and how accurate it was, they usually ended up by asking us to photograph their farms saying: "This is easier than measuring it ourselves'."

A farmer can request that his farm be photographed and it will be put on the list and ran just as soon as enough farms are scheduled to make the llight feasible.

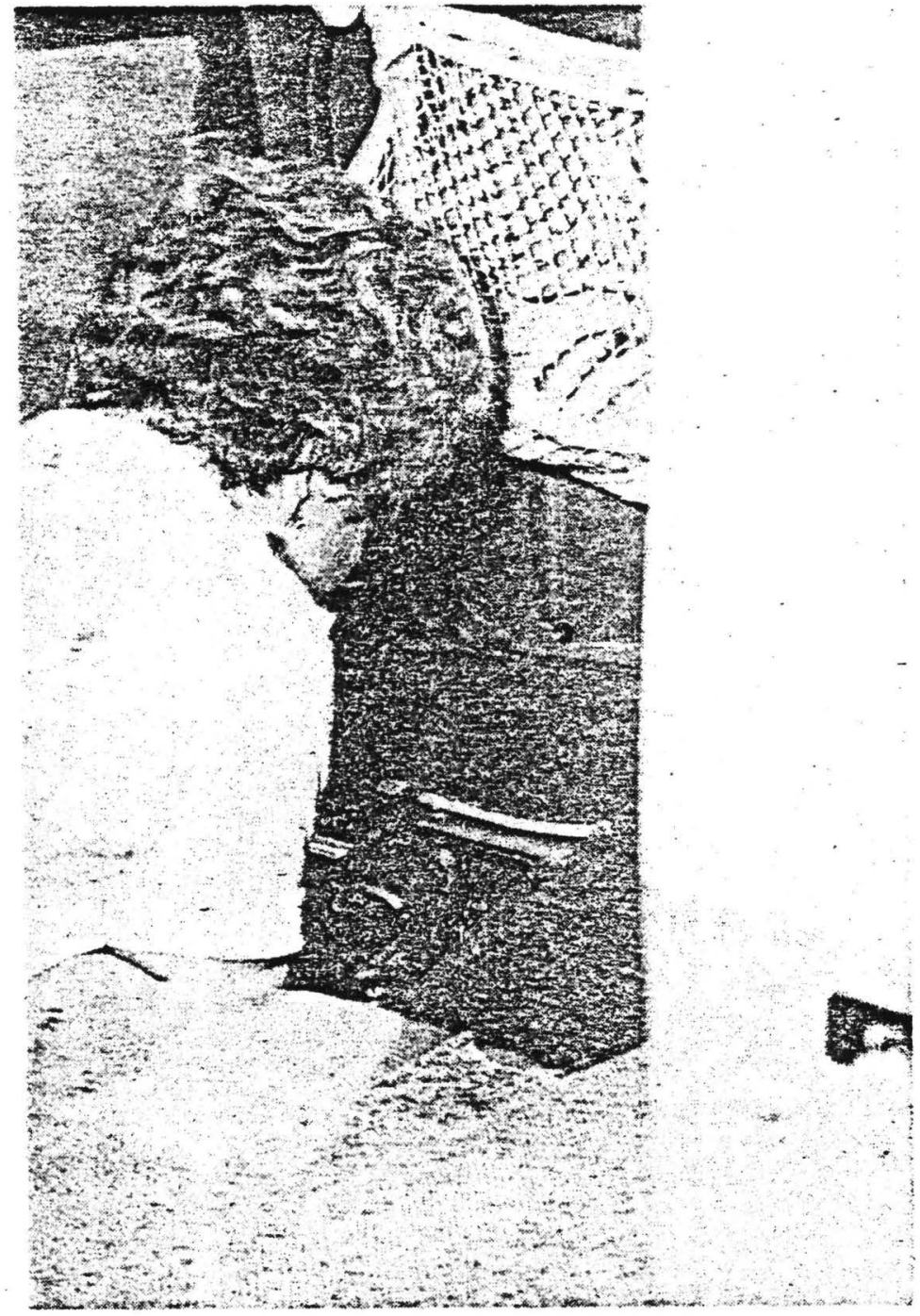

CROWDED, but Mrs. Fojtik manages enough room to take the pictures by lying over the observer's seat. After she snaps the picture she returns to her seat to assist in the location of the next farm to be photographed.

At the present time a flat charge of $\$ 10$ is being made for each aerial photo requested. For this fee the farmer gets guaranteed acreage measurement that ASCS will stand behind. He also gets a copy of the color slide for his own use.

Previously the charge for ground measuring a section of land would be a flat $\$ 8$ plus 10 cents per acre, or $\$ 14.40$ for the job. A commercial pilot is hired for the job, being paid $\$ 45$ per hour for the plane and his services. 
Savings Outilined

"We do not have figures in our office yet as to the possible savings being effected by this procedure," Drachenberg explained, "but in other areas a 79 percent saving in time and a 36 percent saving in actual costs has been realized."

Workers have found that it is much easier to accurately plot the exact acreage of crops from the aerial photographs as opposed to the field measurements, especially if terraces, ponds or odd shaped fields are involved. While it is possible to determine what crop is planted from the air, and from the photographs, the flight crew sometimes drops down to low levels to check and make sure that they are right on the cotton and grain determinations. These notations are made on the photo copy map and taken back to the office for reference.

"We can even spot grain fields that have heavy infestations of johnsongrass," Mrs. Fojtik confided, "but we don't make any record of that."

\section{Slide Catalog}

Elroy Fretag, one of the men who has measured land on the ground for 20 years, is also closely identified with the program and goes along on the tlights to assist in farm identification. He and Mrs. Fojtik have set up a system of cataloging and filing their slides so that the pictures that have been shot this spring are instantly available.

ASCS officials from the 15 counties included in this pilot program in South Texas have all visited the San Patricio County office and have been briefed on the operation. When any county gets enough farms on their ilst to justify a flight they send in a request and the plane and crew out of San Patricio County flies in, picks up the list of farms and an observer to identify the farms, and makes the mapping flight.

Other groups of counties for aerial mapping programs are now in the process of being implemented at the state level.

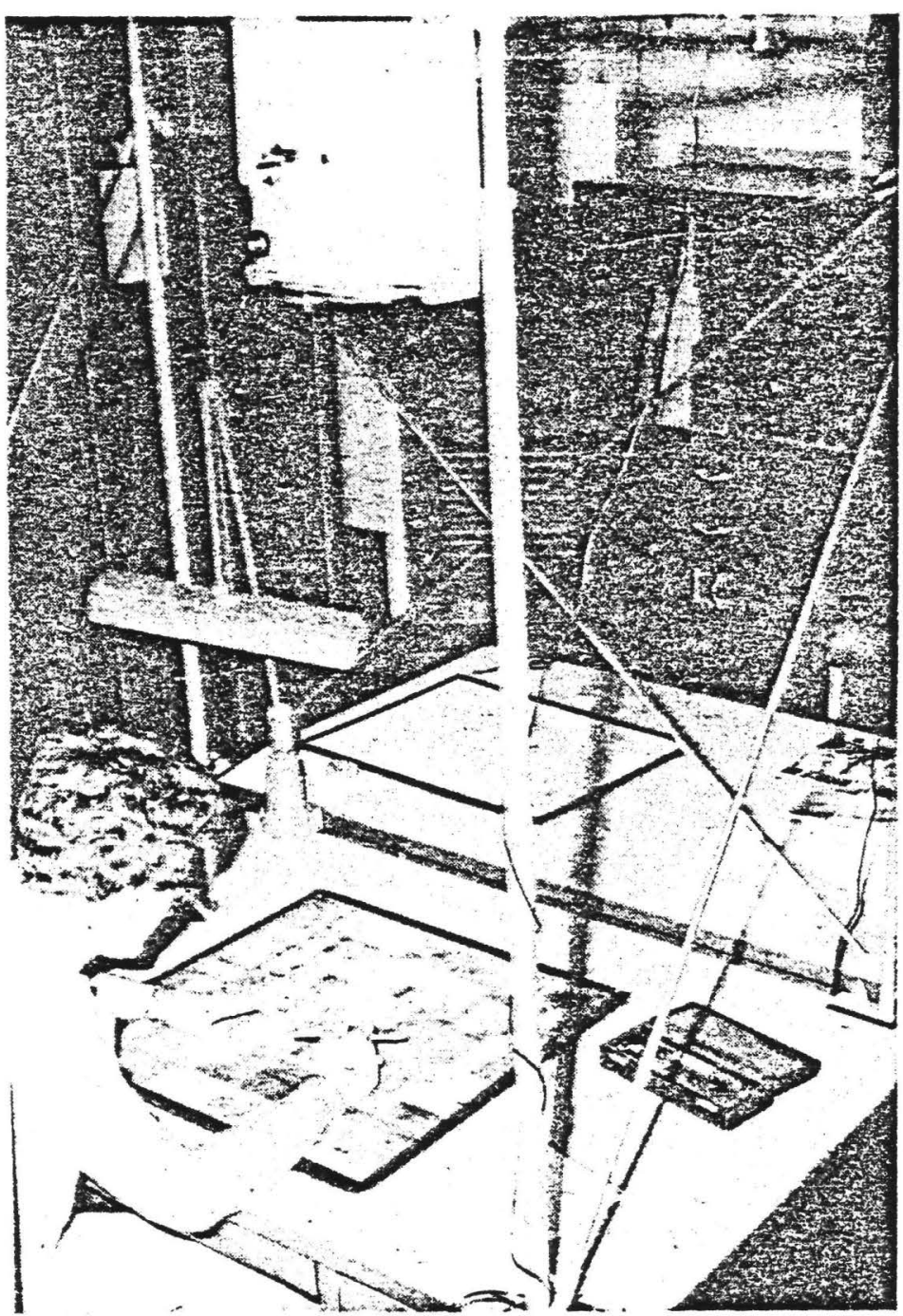

A FRAME has been built over an office desk to hold the projector equipped with a $z 00 \mathrm{~m}$ lens. The slide is projected onto a black and white map of the same area and the acreage is checked, as shown by Mrs. Fojtik. 


\section{Infrared 'spy-in-the-sky' finds farmers' crop problems}

\section{Aerial photos provide new tool to improve crop yields}

BELOW lay the sweeping B expanse of eastern Colorado farmland. While Doug Washburn, Hornick, la. jockeyed the single engine plane for position, his partner Jerry Bindner, Sterling, carefully photographed selected tracts of knee-high com.

"That field looks good to me," Doug observed, glancing down on the irrigated crop.

"Yeah, but let's see what the infrared photographs show," Jerry replied between clicks of the shutter.

Like many others around the nation. Bindner and Washburn have discovered that aerial in. frared photography is a potent management tool which can improve crop yields.

Since last March, the two partners have sandwiched a budding infrared photo service in-between farming full time in eastern Colorado and Iowa. They have photographed over 70,000 acres in seven states since they began. Bindner says.

"In short, infrared enables farmers to locate and identify many problems in their fields before serious crop losses are sustained," Washburn adds. "Although infrared can't pinpoint every problem, the practice can alert farmers to water distribution weed and insect pests, fertilizer deficiencies, erosion darnage, stand uniformity and soil compaction, to name a few of the benefits."

Essentially, infrared film records infrared radiacion which normally is invisible to the human eye. The tilm is par-

ticulariy sensitive to rays re flected by water, heat and chlorophyll-all of which show up in distinct shades of red, magenta, blue, green and brown

Because every plant either bas different amounts of chlorophyll or transpires at a different rate, various plants can be singled out and identified by a specitic color on the infrared film. Grass, for example, shows up as a different color than corn foliage. And because stress on a plant alters the chlorophyll in the foliage, stress caused by hail, drouth, insect or disease damage or nutrient deficiencies also can be detected by the camera's eye, the two Iowa State University agronomy Traduates explain

Their Sterling-based company, called Aerial Infrared Monitoring, works closely with farmers and in cooperation with commercial ag-chemical dealers and sprayers. They offer a full. service program for $\$ 3$ per acre which consists of shooting three infrared phocos of a farmer's crops during the course of a growing season, interpreting the photos and making sugges. tions to improve problem areas in the field.

If, for instance, they conracted to photograph a farmer's irrigated circles of corm. the first photo would be taken when the crop was about knee-high. Weeds, poor water distribution, nutriene defi. . ciencies, etc., can be very accurately located at this time, Bindner claims. A large color /continued on page 16

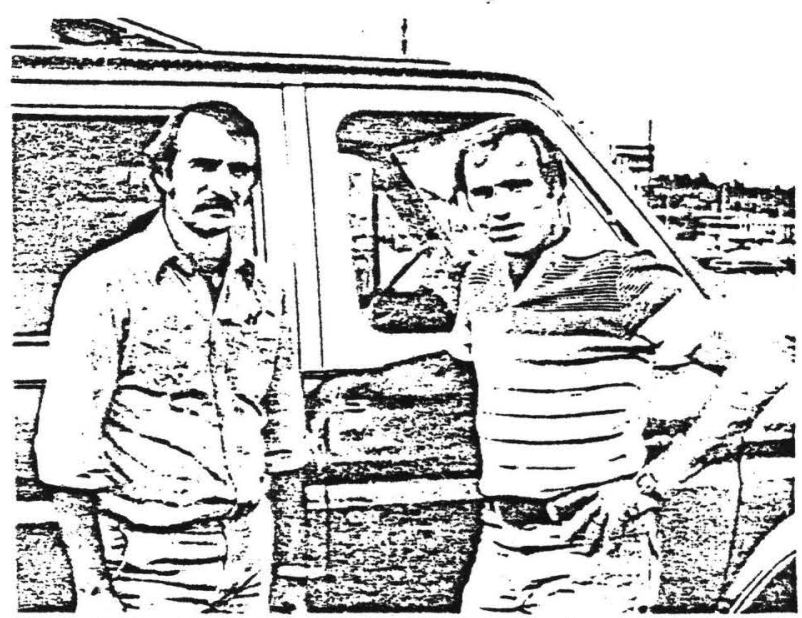

Roger Asniey. Akron, lett. and Jerry Bindner, Sterling, predict aeriat intrared pnotograony will be in wicesoread use in Coiorado within a tew years.

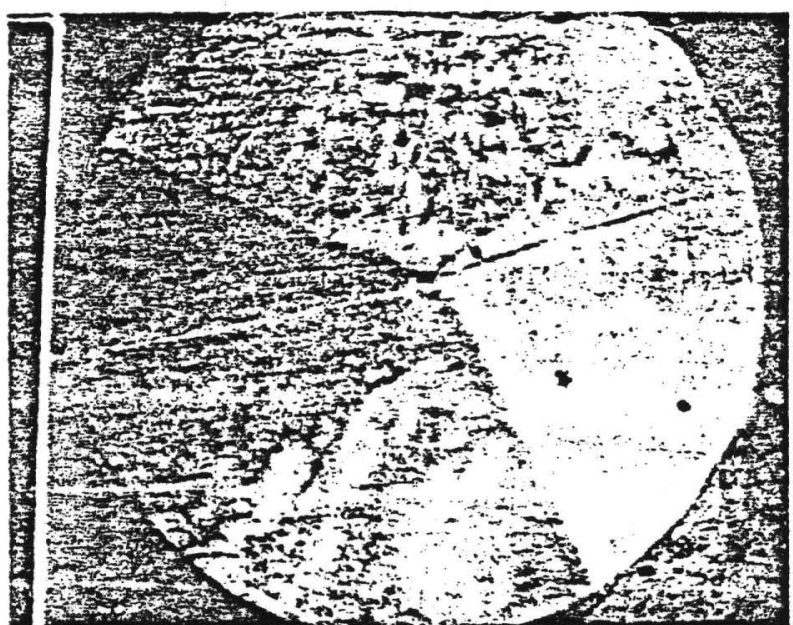

New circle of no-till com shows excellent water distribution (cark shaded area). Black spots and mottled arsas, however, reveal where nerbicide failed to burn off existing vegetation completely and halt weed infestations.

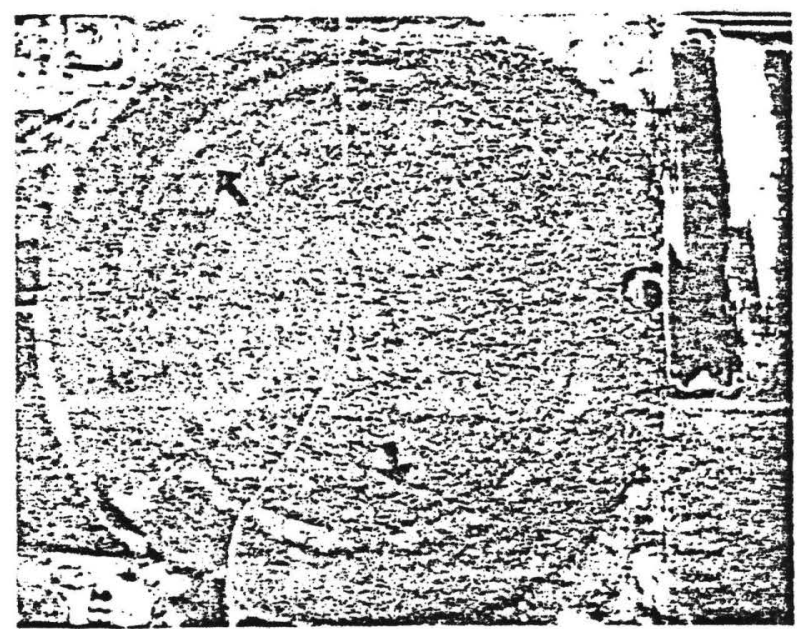

Uneven water distribution shows uo on this aifalfa circle as a light band circling around field (see arrows). Farmer avoided serious production losses by correcting center pivot's nozzjing.

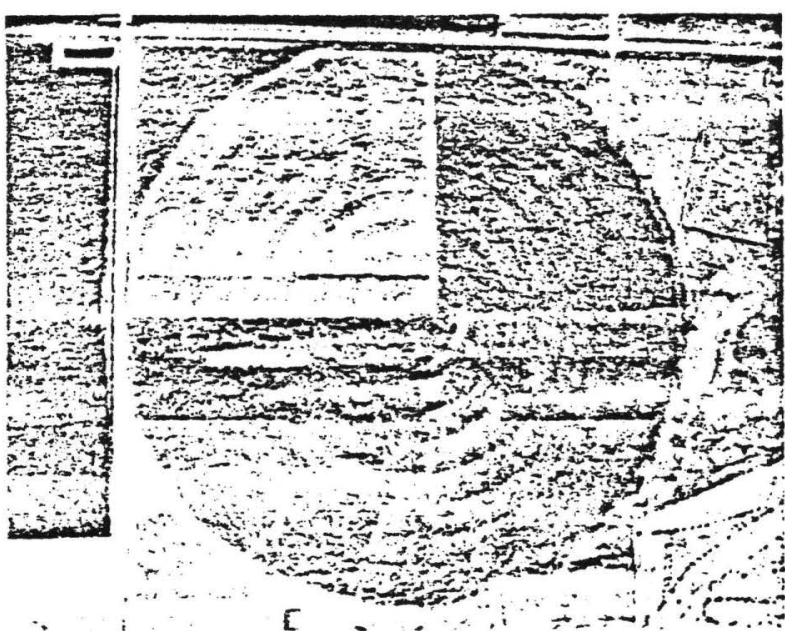

Five vareties of corn and one variety of ointo beans (light quarter) can be seen as contrasting sirios on this circle. Sottom edge of pinto beans aiso shows where field is beginning to be cuitivated. 


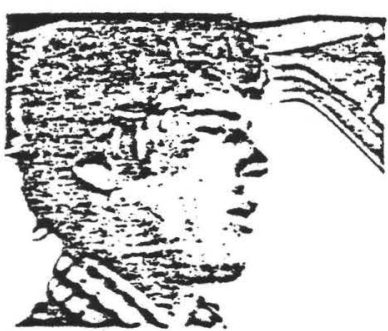

"Aenal intrared pnolography is a new looi management lool now available to Coloracto larmers." says Doug Washoum, Hornicx, la.

reproduction of the intiared slide also is made and serve as a map for the farmer to locate troubie spots in his fieid. Map in hand, the farmer lor custom spraver) can treat specific proolem areas racher than covering the entire field.

The second photograph, taken before polliation, re yeals additional weed infestations or nutrient desciencies in time to make corrections, if necessar;, frior to seed filling.

The third photograph, taken aster tasseling, not only checks to see if the proper corrections were made in the growing program, but also serves as a valuable planning guide for next year's field preparacion. Areas of compaction, for instance, can be pin-pointed and treaced with sulfir to relieve isolated problems, they say.

Bindner adds that intrared photography can be particu. lariy betpril to famers trying to maike accurace soil tests. Inlike Midivest soils where fe-til. ity has been built up over gea. erations of tarming, Westerm soils often have variable soil conditions (e.g., alkainity) even within a small area.

He says that many of the soil tests periormed in the siace are inaccurate since they often are taken in the wrong areas of a Eeid "Random testing is a very poor way to derermine a farmer's true soil situation, yes that's bow most of the soil tests are rade"

Bindne: says an aerial intrared photograph taken after a crop has been harvested provides a yery accurace composite of the soil type on a farmer's feld. It shows area distinctions of moisture holding capacity, oH and copograohy. "A prop eriy iaken infrared photo is an exceilent guide to indicate where the most representarive soil is locaced."

I rould neyer buy a piece of sround unless I had an aerial intrared phocograph caken of the aren." Wasnburn adds. "Infrared doen't replace soil test. ?as

Colorado Rancher \& Farmer ung ground crews - it aids them. Il's an example of how the pho cographic cechnique can be used very efifectively as a man. agement tool."

Although phocos can be raken on mose beid and orchard crops, a iull service program may noc be economically fes. sible on some small grains, Bindner notes. However, a single shot of an open wheat Geid, for instance, can be very beneticial in locating potential low vielding trouble spocs.

Wastiburn adds that the in. frared technique sometimes in. dicares a problem in a farmer's feid that can't be incerpreed just by viewing the slide projected on a screen. "In those cases, we jump in the pickup, 30 directly to the rieid and discuss with the farmer what the prob lem might be."

Although some say that ae rial infrared photography can predict crop yields, Bindner dis. agrees. "Sure, we can iell a farmer if his crop is going to be good or bad, bus 'we're not yes to the point of prediceing accus. rate bushel counts. It may come in time."

Bindner and Washbum generally cover about a quarer section or a single center pivoc circle with each pisotograph they take. "I suppose we could take a series of more detailed phocos, each covering fewer acres, but this would be very costly. We feel the amount of area we cover provides good detail of the field and is reasonably priced."

Washburn says that if their service can correct a minor problem on a quareer section of ground, the farmer should re coup his costs for the service while increasing overall outpur of the land. "From feedback 'ye've received from jamers and ag-chemical deaiers lase year, we'll be doing a lot more work next year," he predict3.

Roger Ashley, owner of a cus. tom spraving and agricuitural service at Akron, enlisted the services of Bindner and $\mathrm{W}$ asiaburn last vear on irrigated corn and sugarbeet ajeids in easterm Washington and western Yums counties.

He uses their service in locating areas to make accurate soil cests, correcting problems in water distribution through sprinklers or flood irigation systems improving weed conirol detecting herbicide injury and improving nitrogen apoication. both through spriskler a systems and ground apolicacions.

In addition, Ashley belieyes ibe intrared phocos will serve to make his empioyee vigilant in cheir hield work. "We pride our. selves on providing a thorough. even application of chemicals on a tieid. We have co do a zood job. All we have to zell is our service, and our business is no better than the service we pro vide.

"When I send a man out to appiy $\$ 7,000$ worth of fertilizer on a farmer's Eeid, he'd becter do a brst-class job. I coulda't zec around to check eyery joo in che pase, but the spy-in-ine sky' now will show any errors very cleaply."

In the incure, Bindner and W ashburn hope to cake more phocographs and do less consulting and interpreting of the photographs. "Interpreeing the ohotos is not the most diffecult part about intrared. With a

list!e practice, a farmer can do it himself. The hardest part of the business is getting consiscencly good quality pictures which really show where and what the problems in a fieid are.

"We made about every error that could be made before we began getting quality photograpins. Handling and processing of the Elon combined with making the proper esposure is a sixill to be developed. It cook us a loe of time and money."

The two enterprising farmeragronomises foresee infrared in use on most farns within the nex: 10 years, and perhaps sooner in the West. "A Western farmer either do scientiñc job of farming or he dosa't farm at all. We bave many soil problems to overcome to obtain maximum yields," Bindner says. "Management through the use of infrared can have siznificant affect on crop yields."

"A famer can'c decend on in. frared to show every problem in his fields and crops. But it sure will pick out a lot of things he never knew were there," Wasnburn concludes. = 


\section{Infra-Red Crop Photos You}

\section{Can Do Yourself}

IF ARIZONA farmers are willing to spend less than Sc an acre, Pinal County agent Jim Little is willing to see that they lcarn how to use a camera with infra-red film and get a good took at the health of their grains and cotton.

No, the bearded Cása Grande resident is not talking about an expensive camera set-up and sophisticated high altitude flying. He's talking about loading a simple, everyday camera with film that photographs heat waves rather than light waves and sticking that camera out of either a rented or a personal aircraft.

"Infra-red photography," said Little. "can be as simple as aiming any camera out of a Cessna 150. That's why I maintain that any grower can do it and that's why 1 think the 3 or 4 s he spends per acre will be returned many times in the improved practices he'll gt: from actually sceing what's in his field."

Color and Cost

According to Litlle, a pilot himself, infra-red pholography points out to a grower the symptoms of an unhealthy field and then allows him to diagnose and correct those symptoms.

"Among the things that infra-red can do," Little added, "is to actually see what is in a grower's field; things which may not be visible from the road.

"For instance, the infra-red system can really be invaluable when a cotton grower is trying to determine optimum conditions for defoliation. A simple fly-over with a camera carrying infra-red film can show him if the cotton has been defoliated property. If such a fly-over is made, and an examination of a slide points out that the cotton is bright red in color, you can detcrmine that the film has picked up lots of heat from the dry leaves still on the plant; leaves that would cause dockage at the gin if the cotton was harvested at that time.

"However," Little added, "if a grower looked at the slide and the slide showed cotton appearing as a brown, then the grower could be assured that proper defoliation was done."

Little added that both cotton and wheat producers might find infra-red "field snooping" invaluable because it let's one see everything from gopher mounds to competative weeds, and from harvester ant nests to destructive insects.

"Because those who use infra-red photography believe in the theory that a cooler plant is a healthicr plant, they are able to look at a cotton or wheat field and quickly tcll if the field is in good condition. Then, anything that looks suspicious or of a different color will be suspect by the grower after careful examination of the field himself."

Little gave as an illustration, which will show up on an id of course. there's nothing wrong with a little green in the fields, but when a grower. is pre-irrigating and he notices from a slide that therre are green, healthy patches of growth all over his fields, then he can be sure that he's gone into the weed production business and he'd better do something before it's too late.

\section{Measure Soil Types}

Little gets even more enthusiastic about the benefits of infra-red photography for those putting in new land. For instance; he says, such a system can be especially useful when a grower is interested in finding soil types and hot spots in his fields.
Because water will show up dark on an infra-red slide, a grower can irrigate new land, fly-nver that land - with an infra-red camera and then determine if some acreage is warming too-much. due to little water penetration. or is getting cooler due to better application.

"The theory behind this:" said Little, "is that heavy soils will photograph cooler on an infra-red slide and those lighter soils will photograph warmer and dryer. Thus, if bare soil is being irrigated, the slides will show a mottled effect due to uneven water penetration. A grower can then mix his soils to. get rid of this effect or he:can determine that if there is only an eighth of his parcel with sandy or hot spots, that small piece of land might not be worth saving, or changing irrigation practices for."

\section{Tax Write Off}

According to Little, a grower interested in infra-red photography. can get started with about as much trouble and money as a trip to a Fotomat.

"The procedure I use," said Little, "is to secure a dependable photo processor such as Kodak, etc., and then figure out a way for you to send or take your photographs in at different intervals. For instance, I use a processing house in Phoenix and wheriever I have film to be processed; I secure it with a cushion material and then put it in the mail.

"Others might. like to find a processor much closer to bome and ihat's fine. At that processor, you wiil also be able to purchase a roll of 20 exposure film for roughy $\$ 8$ a role. And because each exposure can allow you to see 40 acres, you should be able to take a look at 80 n acres on that one roll. And what is eight

Taken from: Arizona Farmer - Rancher, December, 1977 
hundred pennys divided by eight hundred acres? That is I 4 an acre for the cost."

Little added that the film must be kept very cool to protect the heatseeking characteristics. If film is purchased, and ther thrown into a glove compartmeat rather than an ice chest or a refrigerator, thea that infra-red film will measure the heat of that glove box and will show. it to you after you develop it.

And don't forget, he said, the tota' cost of using an infra-red system including the cost of borrowing or renting an aircraft, can be written off of a grower's income tax as a business experise.

\section{Making Your Deeisions}

A few things that should be kept in mind by the grower if he decides to use infra-red is to not make decisions simply by looking at a slide and don't fail to back up your "sky-watching" with good observation on the ground.

"In other words," said Little "good infra-red photograpiny can only be regarded as another helpful tool for management. It must not be eonstrued as a replacernent for good management. A grower should spend some time with the slides soon after they come back from the processor and then determine what it is he's seeing in the fields. But before decisions are made, the grower must take a good look at the ground level.

-Another thing to remember is that it's better to let someone else do the flying due to the fact that one of: the best altitudes is 1500 feet and that's too low an altitude for quick recovery if you're trying to fly and photograph at the same time:

"It's also better to open the wirdows of the aircraft rather than suffer the distortion that many aircraft windows produce: Also, don't tio the aircraft-tip the camera.

"Of course," Littie concluded, "the main benefit of the infra-red system is to coax a grower back into his wheat or cotton fields. I've long noticed that in Arizona, growers will look and feel of their cotton untiI they're blue in the face. But those same growers will plant either wheat or alfalfa and never look at it again after a couple of weeks. Thus, it's my belief that growers will be well served by just using the infra-red system in February for their wheat and in September for their cotton defoliation. This will not make them millions of dollars necessarily, but it will ensure that the growers pay more attention to their grain and cotton and that's about as good a crop insurance as you can get." K.L. 


\section{Aerial infrared is working}

Farmers are beginning to use aerial infrared photography as a profitable management helper

Aerial infrared (IR) photos of your farm may show you that management errors you know you've been making are adding up to a lot more yield loss than you realize. They might also reveal previously undetected problems.

Going through infrared photos in the office of Jack McKinnon's Prairie Agri Photo, Carman, Man., shows that many problems in seeding, fertilizing, or weed spraying stand out like a black eye on an $\mathbb{R}$ photo. What may be judged from the ground as a few bad patches may plainly show up as 20 to 40 percent of the field when viewed in an IR photo.

MeKinnon explains that in IR photos, the deeper red color indicates healthy growing plants. A pinkish color indicates stressed plants and sometimes weeds. A greenish tint represents soil showing through in sparse or seedling crops. Other shades have meaning to an eye experienced at reading IR photos.

With two years of experience now, McKinnon and his fulltime agrologist, M. Gupta, who has a Ph.D. in agronomy from the University of Nebraska, can diagnose almost any crop problem that shows up in their $I R$ photos. However, identifying problems on film is only the beginning of the process. When problems show up-and most farms have some-Gupta goes to the farm, points out the problem area, and the farmer and he go to the field to check it out. "In all cases," Gupta says, "farmers already know or can determine what the problem is and what went wrong before we get to the field."

McKinnon charges about $\$ 40$ to take an $\mathbb{R}$ photo of one square mile of land and $\$ 6$ for a print from the IR film.

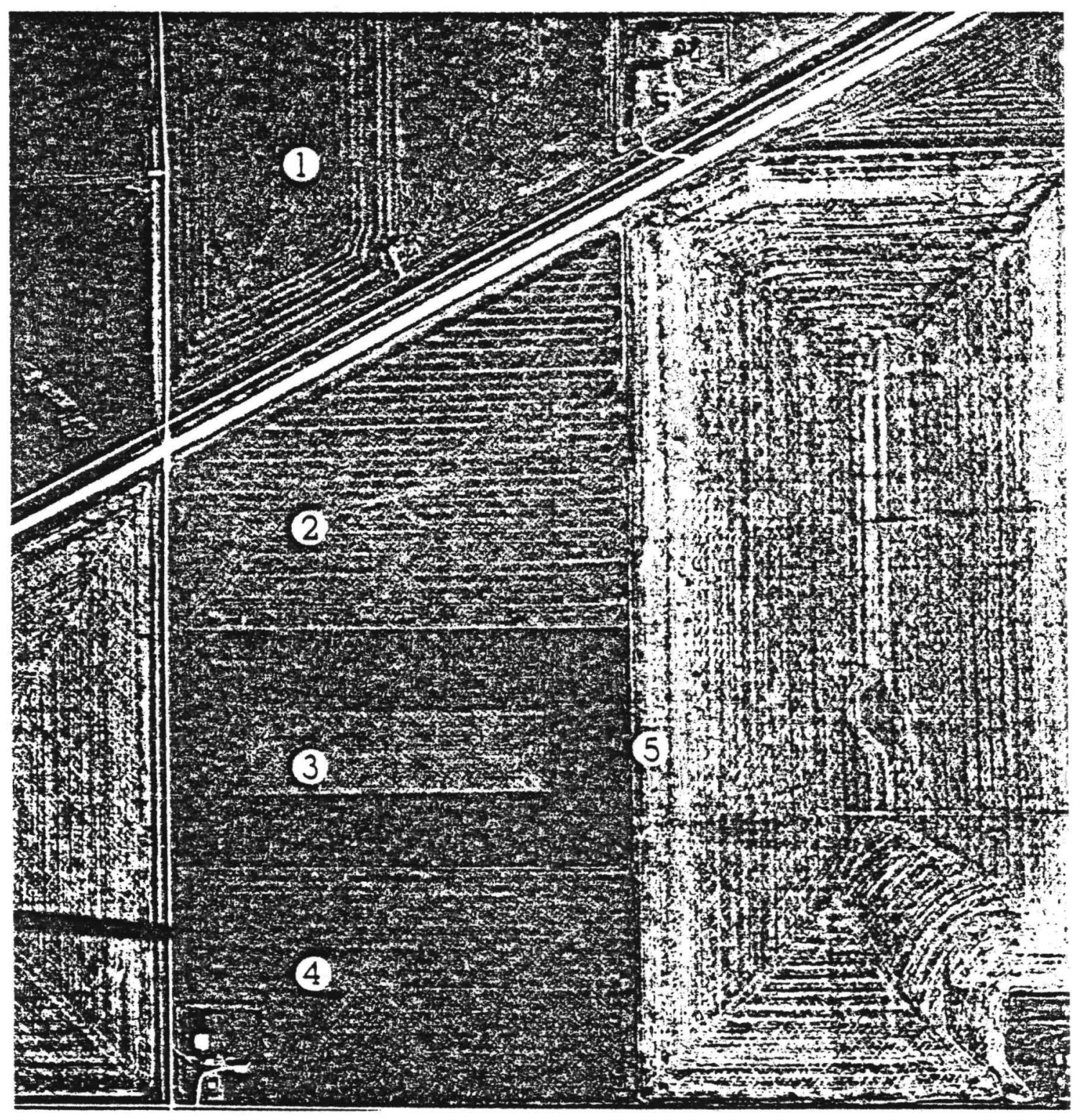

The deeper red color indicates healthy plant growth. A pinkish coior indicates stressed plants. The greenish tint represents soil showing through a seedling crop or sparse plant growth.

Granular fertilizer sporeading problem

Lquid fertilizer misses

Nitrogen ran out in a wheat field 3

Drainage problem in a flax field 4

Phosphate ran out in a bartey fieid $\mathbf{6}$

(continued) 


\section{Aerial infrared}

lcontinued

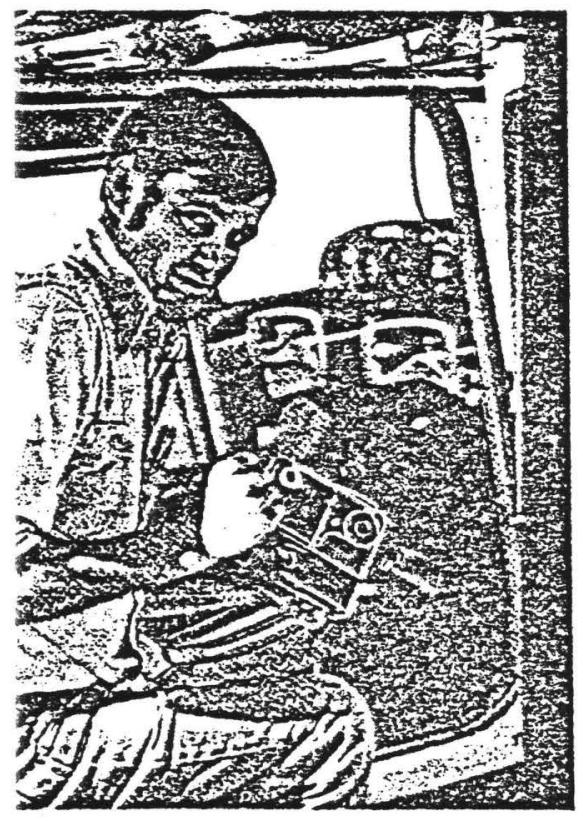

When IR photos are taken early in the growing season, there's sometimes still time to take corrective action or try an altemative cop. Some examples from last spring: Severe crop damage showed up in part of a sugarbeet field. The problem tumed out to be wireworms. The farmer still had time to control the insects and replant the damaged area. Similar corrective acton was taken on another farm where a seedling coo was attacked by flea beetles. And still another tarmer found his oat field was heavily iniested with thistles. He plowed it up for summertallow.

During his busy saason, Jack McKinnon leases iwo planes to get phoros.

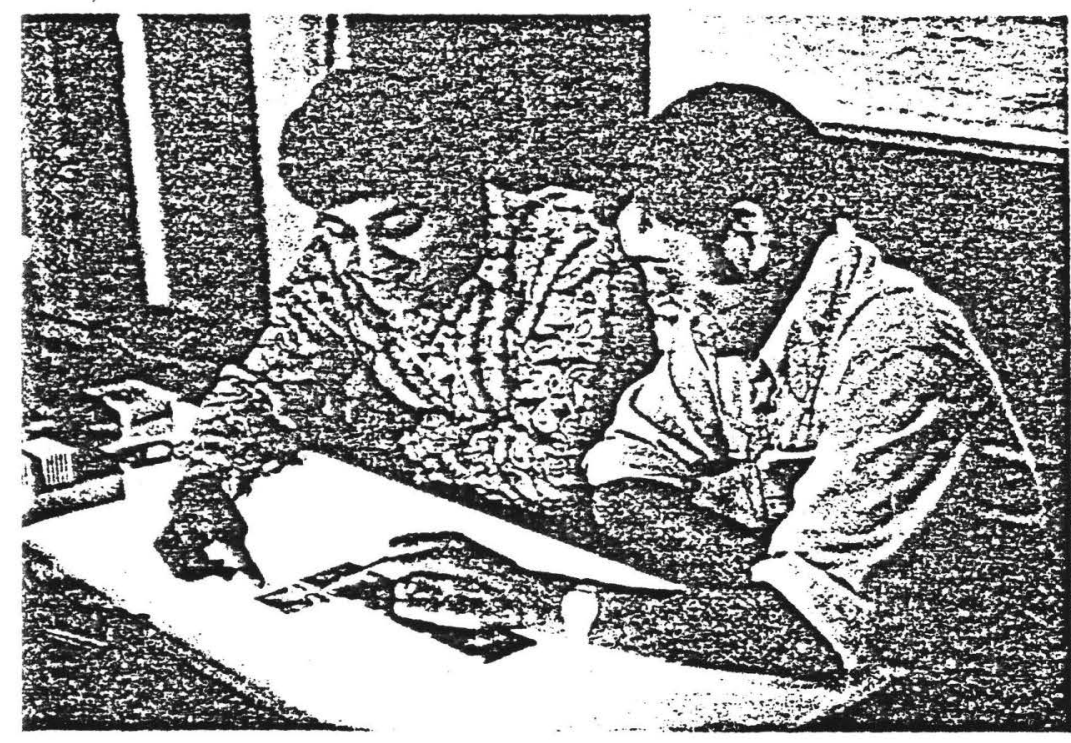

MeKinnon and agrologist $M$. Guota examin IR film irom

recent anoto-shooung session.
IR photos can spotlight problems that aren't readily apparent from a pickup. For instance, Gupta says $I R$ photos can also be heipful for determining drainage problems, soil types within a field, and where to take soil samples in a field.

When $\mathbb{R}$ photos are taken in the middle of the growing season, it's usually too late to take corrective action on obvious problems. Howeyer, the photos can be used to help plan a better management approach for the next year. And a lot of problems do show up in midseason $\mathbb{R}$ photos. Wild oats, wild mustard, wild buckwheat, thistles, and some other weeds show up especially well at the head stage in almost any cop.

Last year, an especially frequent problem was uneven fertilizer spreading, whether it was custom-applied or applied by the farmer. Weed-spray misses were frequent, too. One tarmer, who seeded wheat with seed boxes on a three-disk hookup, discovered too late that the middle disk wasn't penetrating deep enough. The result? Extremely poor wheat gemination on a third of his seeded acreage.

Bill Craddock, who farms 14,000 aces in central Manitoba, has McKinnon photograph all his fields and says the inves:ment is quite worthwhile. "It takes a lot of time to scout every field for problems," he says, "and you can miss comers that you should have checked. Recent IR photos of a field of suntlowers showed we have a severe wild-oat problem in a comer of the field. I didn't know it was that bad. IR photos also help me verify which emplovees are doing a good job in the field. Some of the men I had last year aren't with me this year. I'm also negotiating with a commercial applicator for a better price on the job he did. It helps to have photographic evidence along when you have to go into something like that."

McKinnon is tinding a widening market for his aerial IR service. Several custom apolicators now hire Prairie Agri Photos to photograph their customer's farms to show them they did a good job. Wildlife groups, conservation organizations, and real estate agents are also finding uses for aerial IR photos.

In Ontario, Agriculture Canada researchers are using aerial IR to keep track of bacterial bean blight in the province. In conjunction with this, CDA's cop protection division started what it calls a "select seed pro. gram" for white beans. This involves bringing in disease-free seed from the westem U.S., inrreasing it in Canada, and then using this seed for planting in Ontario. Aerial IR photos show that not all bean growers go along with the program, although most do. In fact, the program has been quite successful. In 1968, aerial surveys showed that 6 percent of the white bean aop in Ontario had been intected with bacterial blighr. With the clean-seed program in effect, this has dropped to less than one-tenth of one percent.

McKinnon says most farmers who have had $\mathbb{R}$ photos made of their felds plan to keep using the service. They realize, of course. that IR photos have to be supplemented with field inspections. But it helps, they say, to have the ivhole farm in tront of you when you're planning your copping program. 


\title{
Cirrus Project Makes Valley Infrared
}

\author{
Page 6 Rio Grande Valley Edition - Southwest Farm Press • \\ Fet 23.1978
}

\author{
By Calvin Pigg, Editor
}

WESLACO, Tex...Smile Rlo Grande Valley, you're on candid camera, and in infrared living color to boot!

It goes without saying that considering its diversified agriculture .. and large numbers of sophisticated ag research outfits based here .. the Valley could become one of the most frequently photographed places within the United States.

Fact is, it's probably "shot" by cameras mounted in flying aircraft and circling spacecraft more today than any other place in the country.

The Rio Grande Valley, it turns out, has become a proving-ground for what scientists call "remote sensing." Evaluate Surface Characteristics

Remote sensing, they define, is the ability to "evaluate the characteristics of a surface without being in direct contact with that surface."

From flying aircraft and higher-flying Skylab, ERTS and Landsat 11 space vehicles, the Valley has been analyzed by remote sensing methods for everything from its soll and water resources, disease problems on its crops, to the growth of its expanding cities.

The latest "shot," expected to be made this month, is another "citrus census." It is being flown under the auspices and sponsorship of the. Texas Citrus Mutual of McAllen.

The special flights and picture taking in color infrared (IR) are to be made from Edinburg westward, where 75 percent of the Valley's citrus crop is located, according to TCM general manager Mike Wallace.

Flights are to be made by private flying service. Seek Practical Applications

While the majority of remote sensing activity falls within the realm of research, concept promoters are anxious to help find practical ways for private industry to use the relatively new tool.

Earlier citrus census flights across the Valley have been flown, shot and film developed and analyzed for less than a

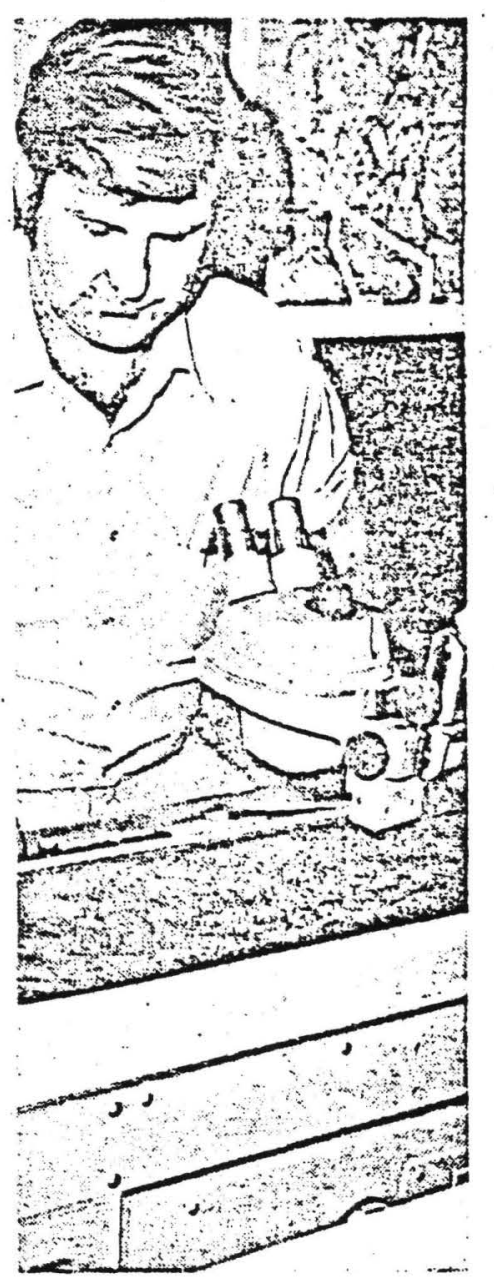

SAM ENGLE, USDA.ARS entomologist, presides over a light table studying color transparencies made by aer. ial photography of Valley cit. rus groves. 
"They've taught Wallace and his staff how to analyze the $I R$ photos so proper information can be drawn and made available to any TCM member."

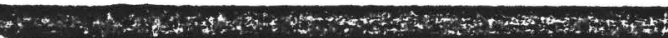

penny per acre .- four-tenths of a cent to be exact, they report.

Counting grapefruit trees with a camera beats doing it on hoof by a "long shot," says Wallace who is concerned about such things as shoe leather and costs.

Teaming up with Dr. William G. Hart of Weslaco, USDA. ARS research entomologist and remote sensing authority, Wallace believes TCM's one of the first organizations in the nation .. certainly within the citrus industry .. to use the technique to improve and promote the industry.

For one thing, says Wallace; a non-resident owner of five acres of Hidalgo County grapefruit who lives at Des Moines, lowa, would like a pretty framed picture of his "estate" to brag about to his snowed-in neighbors.

Grove Care Shows Clearly

But more Important he can tell from such a photo what kind of care his grove is getting down in the Valley.

In addition to aesthetic value, an aerlal photo of a specific citrus property can be helpful in analyzing a grove's care, overall management and any needs it may have, contends Wallace. The application goes beyond the fact that 70 percent of the citrus is owned by non-residents.

Some of the larger grove care firms are screening the aerial shots with a number of objectives in mind.

Dr. Hart and his associates, saying any object as big as a tree reflects well on the special kind of. film used, have developed certain methods of reading the photos and pinpolnting maladies such as brown soft scale or mealybug damage.

Projects To Refine Methods

Dr. Hart and assistants, Rene Davis, pllot and photographer, and Sam Engle, entomologist, have a variety of projects ongoing which they hope will further refine their methods.

They've taught Wallace and his TCM staff how to analyze the I $R$ photos so proper information can be drawn and made avallable to any TCM member both in the Valley and beyond who may want it:

With 12 years experience with remote sensing, including early work in forestry, Or. Hart says low-level IR photography taken at approximately 10.000 feet with a 12 . inch focal lenath lens has far more immediate application to agricultural needs than do those highly.touted shots from space.

He suggests that needed plcture resolution isn't to be found via satellite orbiting cameras, and the lag time required to obtain pictures from the National Aeronautics and Space Administration .. two to three wesks after they're flown .. is too lang to be usefut in most cases.

Scientists are attempting to harness space photos to in. ventory all sorts of earth resources, even with computer analysis.

These high-flying shots don's help Valley farmers much with their mealyougs, Illustrated the entomologist.

"Anything really practical to come from space pictures, in necessary detail, is perhaps 10 to 20 years away, if then."

Nonetheless, technology now on-stream for both low-level and soace for photography, such as the citrus census, is fascinating and no question about that!

The entire Valley has been flown at least four times now, maybe more.
Interest Started Years Ago

Wallace says he became interested in ARS remote sensing endeavors years ago when the need arose to gather a firm figure on exact number of citrus trees in the Valley. He pondered whether certain insect and disease problems might, also be better spotted from the air.

The initial citrus inventory flight was made in 1973.

"We thought we had 85,000 trees at that plme, but the pictures revealed the figure was closer to 74,400 . Obviously we were wrong in our first belief."

That first "grapefruit flight" was flown by a souped-up NASA aircraft flying at 20,000 feet. All the red tape it took to arrange the over-flight was staggering. "We decided after that first time we'd try another approach if we did it again." confided Wallace.

The flight was made on the basis of pesearch strictly. Distinguish Types of Trees

"But we not only discovered that we could get an accurate tree count," said Wallace, "to our surprise we could distinguish between. orange, grapefruit and tangerine trees."

The analysis technique has been later developed to the point that even the age and the variety of fruit could be determined. The color IR film is highly reflective of the chlorophyll content of leaves on a tree.

Dr. Hart says now that methods are reflned even better, he belleves a single overflight and eye-analysis can show up to 95 percent of all the trees within the region. With lighttable screening which takes a little more time the other 5 percent, usually smallest trees in newly planted groves, can be documented on the photos.

"By careful analysis we think we can find them all now." Vegetation Color Differences

Vegetative and ground color differences show up best with flights timed two weeks after an irrigation.

"We soon saw the possibility of gathering all kinds of information from the photos," said Wallace, who is supervising the planned February upper Valley overflight.

One day he hit upon the idea of sending the red-tinted photos to grove owners through his organization as a way of showing member-owners a visual report of precise management their groves were getting from the tending citrus grove care firms.

That's what he's intending to do this spring. Offers Seven-Point Analysis

Not only will owners and caretakers be offered a choice of either an eight-by-10 inch aerlal print or a $35 \mathrm{~mm}$ slide transparency for a nominal fee, but TCM, entering the management assistance arena, will offer clients a seven. point analysis based upon an expert review of the picture itself.

The evaluation form accompanying the photo. Wallace pointed out, will cover such items as the presence on trees of sooty mold or leaf defollating insects. Sooty mold is caused by brown soft scale, whitefly, citrus mealybug, citrus blackfly or aphids.

Second category on the checklist are diseases .. foot rot, gummosis and psorosis.

Major problems with drainage or Irrigation show up nicely in the infrared photos, said Wallace, the third category to be evaluated for clients .. elther wet or dry spots in fields or actual standing water highlighted. 
Show Tree Nutrient Imbalances

Fourthly, certain tree nutrient Imbalances snow up to the

"We're seeing our groves from an angle we've never seen them before. We're happy with the program and the potential it offers grove operators and owners in a practical way."

trained photo analyzer. The presence of iron chlorosis, or nitrogen, phosphorous or potassium deficient trees in the groves will be pinpointed for the owner.

Based on enlorophyll content of ground cover .. or lack of ground cover .. ground weeds or vines will be noted for the. owner or caretaker.

The sixth check for citrus people involves the very presence or absence of trees. Missing, dead or defollated trees are scheduled to be rated on the evaluation form.

Wallace and his staff save the best for last... the seventh classification llsted as "no visible problems."

\section{Regular Feature of TCM}

Unique as it is, he hopes the grove photo analysis can become a regular part of the TCM program. "We're seeing our groves from an angle we've never seen them before," sald Wallace.

"We're happy with the program and the potentlal it offers grove operators and owners in a practical way."

He said ideally the Valley, for eltrus inventory purposes, should be flown twice a year .. once in February and again in September after general rains.

Certainly not hoping It'll happen. Wallace and Dr. Hart will be on their toes seeking an opportunity to evaluate tree freeze damage via remote sensing for the very first time... anywhere within the industry.

Spray Only Where Needed

Remote sensing pioneer Dr. Hart said that in addition to locating varlous tree problems, he sees the real value in photography analysis of groves .. over the usual ride and windshield method - as allowing managers to spray only certain parts of a eitrus grove. The colored photos will dellneate even a single tree that needs attention, again if the analysis is correctly made.

The benefit in.being able to treat only a portion of a grove is rather obvious. It can cut chemical control costs and not interfere with beneficlal Insects in the rest of the fleld.

In addition to agrieultural uses, the aerial $\mid R$ sensing also has many other potential uses sueh as taxing agencies, eity planning units and water distrlets. By sever al organizations utllizing the same maps for their varying purposes, said Dr. $\mathrm{Hart}$, the eost to any one user would eome down considerably.

Work by ARS selentists on solls, water and ettrus resources is continuing.

As one example, Dr. Hart and Davis are. engaged in continuing studles with one well.known grove care operator in the Valley, Gil Ellis of Mission.

Overflights of Ellis' groves are being made regularly this winter in hopes of discovering things they may have missed before.

To take the procedure to the ultimate, noted Dr. Hart, Ellis is being trained to analyze the red-tinted photographs himself as part of his grove management decisions.

Why infrared color over straight color or black and white aerial photography? Explains the ARS researcher: "A tremendous amount of added information ean be gotten from an I $R$ shot over normal blacx and white. The reason is that muen greater color contrasts are deteciable with IR."

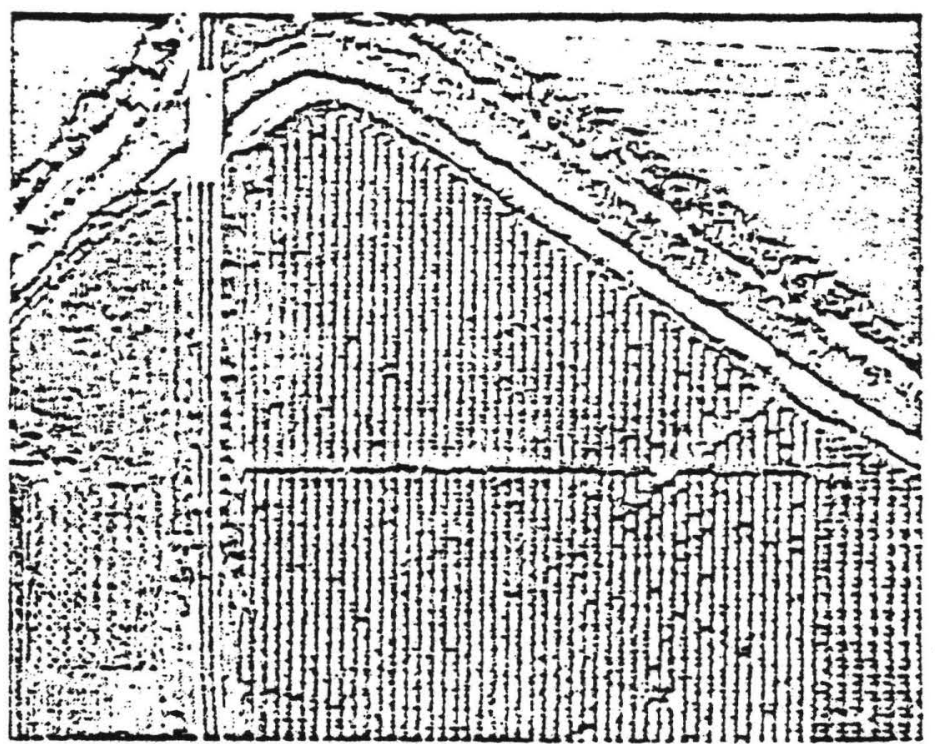

USING COLOR IR fllm, aerial photography gives un. precedented detail of ground area below, eitrus trees in Hidalgo County.

"After a few years on the light table a dark pink bloteh on the map shows up in your mind as the prettiest green grapefruit tree you've ever seen."

As for Wallace, the opportunity for a commodity organization to be of specifie sepvice to its members is obvious - particularly when many paying members live 1,000 miles away.

"Really, we're equally encouraged by the response of our big Valley grove owners and grove care operators to our idea as we have been from the five-acre guy who llves in Des Moines." 


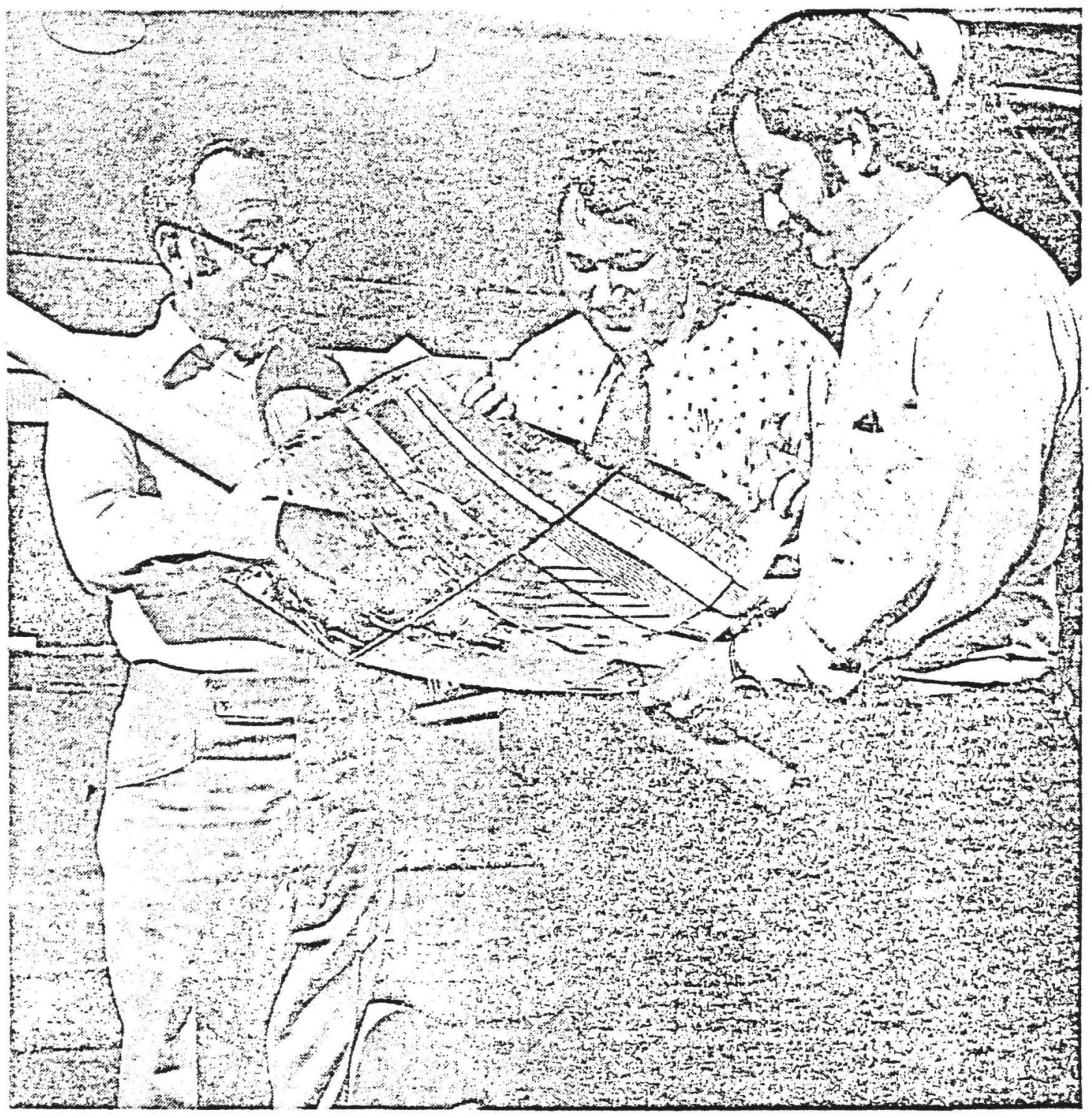

IF YOU NEEDED TO count the Valley's eitrus trees you'd head for the groves, note pad in hand. Right? Wrong. You'd take to the air with camera and special film. Another eitrus inventory is underway, and with some speclal .. and practical - applications. Dr. BIII Hart, USDA.ARS project leader and remote sensing buff, on left, Mike Wallace, general manager of Texas Citrus Mutual, and Rene Davis, pilot-photographer for USDA-ARS, make plans. 


\section{A MODERN TOOL FOR}

\section{THE MODERN IRRIGATOR}

by Dave Aeilts

AT least one day each week during the summer-without fail-Geraid Smith, Fargo, N.D., takes to the air in a small, single-engine plane. The landscape from $1, ; 00$ feet is breath. taking and, as he wings his way over the countryside, he snaps several pictures of the cropland below him.

Aerial photography is hardly a hobby for Smith, who is a management consultant to several farming operations in the Dakotas and Minnesota. Rather, he takes these photographs as a routine part of the consulting service he offers to area irrigators who have hired him.

The pictures he takes are no ordi. nary snapshots. They are "infrared" color slides taken with a special heatsensitive film that records a radia. tion invisible to the human eye. In. frared differs from: standard color film in that it records the lush green of a growing crop in deep, dark red colors.

As a troubleshooter, Smith relies on infrared to help him spot poter. tial problems in fields under irrigation. "I got started taking infrared photos about tive years ago," he explains. "T found that it was a way that I could pick up irregularities in a field that I couldn't see from ground level."

The "irregularities" Smith speaks of are variations in the color of the irrigated crops as seen from the air. These variations are more vivid when photographed with infrared film than with standard color film. Some of the variations in coior are caused by natural phezomeza-like a dirference in soils within a beld-and are of little immediate concen to the farmer.

Other yariations in the color of a field are more ominous because they indicate the presence of an economic

\section{7}

Taken from: Dakota Farmer, April, 1978

\section{INFRARED}
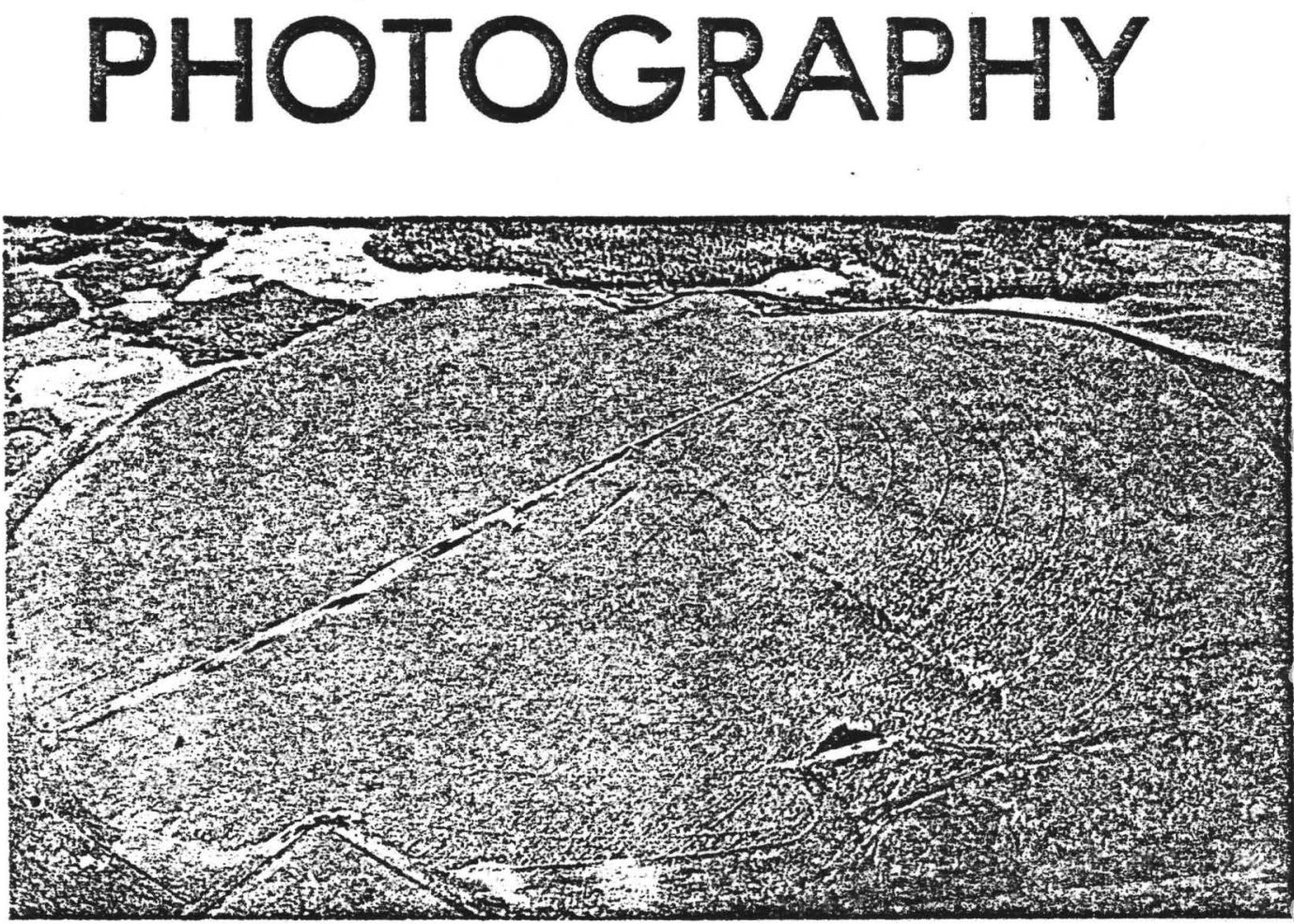

A healthy field, with a properly functioning irrigation rig at work.

hardship-such as an insect or weed infestation, poor soil fertility or a malfunctioning irrigation system. It is to these variations that Smith turns his attention.

Of course, notes the management consultant, it's not always possible to diagnose the exact nature of the variation from the infrared slides. Further investigation on foot is often required in order to identify the cause of the irregularity spotted from the air.

Infrared photography is simply a tool that helps Smith pinpoint difficulties in a growing crop before they become too large and too costly to handle. "It's just a red flag," he states, "a warning that there is something wrong and that it should be investigated."

For example, Smith recalls one field of irrigated potatoes which looked fine from the ground but yieided poorly at harvest time. "We went back and looked at the infrared slides and we could see quite obviously that the irrigation system wasn t putting on water in a uniform fashion." he explains.

As a result. Smith ran a thorough check on the irrigation system and discovered that it had been fitted with the wrong size nozzles. "We aiso checked the well and found that it wasn't putting out as much water as it was supposed to be putting out," adds the consultant.

In an infrared slide of another field-irrigated durum wheatSmith observed that one-quarter of the circle was deeper red than the rest. Consequently, he took soil sam. ples in both areas and found that the area with the deeper red color had more organic matter in the soilmore water and nutrient holding capacity.

"The nitrogen in that quarter was up around 30 to 40 pounds," he states, "while the amount of nitrogen available to the crop in the rest of the circle was negligible-even to a depth of four feet." As it turned out, the quarter with more organic matter had been in soil bank the pre. vious year.

The shortage of nitrogen avail- 
able to the crop in the rest of the circle was confirmed at harvest when it yielded considerably less than the quarter with the high organic levels. Although Smith's discovery was made too late to benefit the durum crop that year, it will help in subse. quent years.

"We know now that, when we raise small grains on that circle in the future, we will have to do a much better job of getting the nitrogen on at the right time-during the peak growth period of the crop," he expiains. "And I think we will find the same to be true with corn."

The West Fargo consultant notes that infrared is also helpful in spotting potential "profit robbers" like weed and insect infestations. Insects like grasshoppers which infest the edges of a field first can be detected early and stopped early, saving the cost of treating the whole field.

Other damaging insects like wireworms, which tend to be pocketed in a field, can be located and treated on a spot-by-spot basis. Likewise, patches of noxious weeds can be pinpointed with the help of infrared slides and their locations noted for spot treatment the following season.

Smith recalls a patch of wild oats which he spotted on an infrared slide one summer. "We had no trouble locating the patch next spring," states the consultant, who often carries a portable slide vicwer with him to the field. "We went in and applied some Avadex just in that part of the field."

Smith points out that infrared photography has other important benefits besides its value as a "trou. bleshooter." Because infrared film assigns different color shades to different soil types, it is also instrumen. tal in determining the major soils and their boundaries within a field.

Based on his knowledge of the soil boundaries on his land, an irrigator can tailor fertilizer and water applications to fit the requirements of these soils. Infrared can also help identify specific problem areas in fieids-like areas with high alkalinity or poor drainage.

How large does the irrigator have to be before it's economical for him to use infrared aerial photography in his farming operation?

"Any irrigator can make use of infrared whether he's got one system or 100 systems," comments Smith. "If he's got 100 systems, perhaps he'll want to hire a pilot and a professional photographer to handle the job for him."
If the irrigator has just one system, Smith suggests that he get together with his neighbors on a cooperative basis to hire a pilot and a photographer. He points out that, in some areas, the Soil Conservation Service has purchased equipment and film and is doing infrared photography for growers for a fee.

Or you may want to hire a pilot and take the infrared photographs yourself. "If you have a $35 . \mathrm{mm}$ camera, access to infrared film, buy yourself a filter to put on the end of the lens and have a pilot friend or someone who will take you up and fly you around," states Smith, "it's a simple thing to do."

Smith estimates that it would cost as little as $\$ 15$ to $\$ 20$ per hour to hire a pilot and an airplane. But he notes that there is often a flying farmer in the area who will take you up just for the fun of it-fly you around and maybe even take some infrared photographs of his own land.

The cost of the infrared film isn't that high either, according to Smith. It runs around $\$ 5$ a roll with developing prices ranging from $\$ 5$ to $\$ 8$ per roll. He warns, however, that you may have to hunt for a source of infrared film because not every store has the facilities to handle it.

Since the film is sensitive to heat, it has to be shipped in dry ice and stored in a freezer when it arrives. "I get my infrared filp through a camera store here in Fargo and sonetimes I have to wait awhile for it," states the farm consultant, who special orders his film in large quantities.

Learning to take infrared photographs isn't particularly difficult. For best results, Smith suggests taking them after $10 \mathrm{a} . \mathrm{m}$. and no later than 3 p.m. "I've taken them as late as 5 p.m.," he adds, "but it's so much darker then and the film picks up a lot of these very deep colors which are hard to separate out."

Smith also advises the amateur photographer to keep the sun at his back when shooting infrared photos from a plane. "If you shoot with the sun opposite, you're going to get a lot of glare on the end of the camera lens," he explains. This will result in a bleached-out picture with poor color resolution.

As for altitude, Smith has found that flying at about 1,500 feet allows him to shoot an entire quarter section of land per frame of film. "But that's something you can experiment with," he advises. "Just tell the pilot to go higher or lower so you can fit whatever field you're shooting into that frame.

The nearer the camera is to the field, the better the color resolution of the photographs will be. So Smith advises using a wide-angle lens rather than a standard camera lens when shooting infrared. "You can get down much closer with a wideangle lens," he notes.

How does the irrigator go about spotting and identifying a potential problem in his fields once he has taken the infrared photographs and had them processed into slides? Perhaps the best way to go about it is to set up a slide projector in his home that can blow these slides up to a workable size.

Then Smith advises checking the slides over carefully for any irregularities in color-like a dark spot instead of the normal red coloration that infrared film assigns to nice green foliage. A dark area in the field could be an indication of exces. sive water application or weed growth.

"If it's a real light spot," Smith notes, "it could be an indication that there isn't much foliage there." A light spot in an irrigated tield could be a sandy knoll where the crop isn't doing as well. It might also represent a difference in soil type or an accu. mulation of salts in the soil.

A lighter colored area in the middle of the field could also indicate the presence of insects at work on the roots of the plants. "It would be an indication to me that wireworms or cutworms or an insect of that nature was causing the problem," states Smith.

The shape of the discoloration on an infrared slide can also lend the irrigator a clue as to what caused it, according to Smith. If the shape is irregular or has.little uniformity, it is most likely due to natural causes such as difference in soil types, insects, weeds or disease.

On the other hand, if the dis. coloration is. straight-lined and would follow the pattern of a pesticide application, a planter, a cultivator or a center pivot irrigation system, it is probably caused by something mechanical. "The shape of the irregularity will at least give you an idea where to look," Smith notes. 
Of course, the final step in locating and identifying a problem which shows up on an infrared aerial slide will involve checking the field on foot. Smith suggests that the farmer take a small. hand-held slide viewer with him to the field to help him pinpoint its exact location.

Infrared photography is a valuable management tool for the farmer. contends Smith. particularly if he ir. rigates. "The irrigator has more money invested in his crop and, because of that. he's. willing to spend more time and effor on managing his investment to make sure he gets the maximum. return on it," he states.

But Smith notes, too, that this new ma .zement tool can benefit any fant.er. whether he irtigates or noc. "If you're a dryland farmer and can stand flying," the farm consultant advises, "get up in the air and take a look at those crops because there's a lot of things you don't see from the ground level."

"Once you get up in the air and take a picture of a field," he continues, "all the sins that you have committed in managing that crop are exposed on film." And the sooner you take advantage of this tool, Smith concludes. the sooner you can begin to correct management errors. either now or in the future.

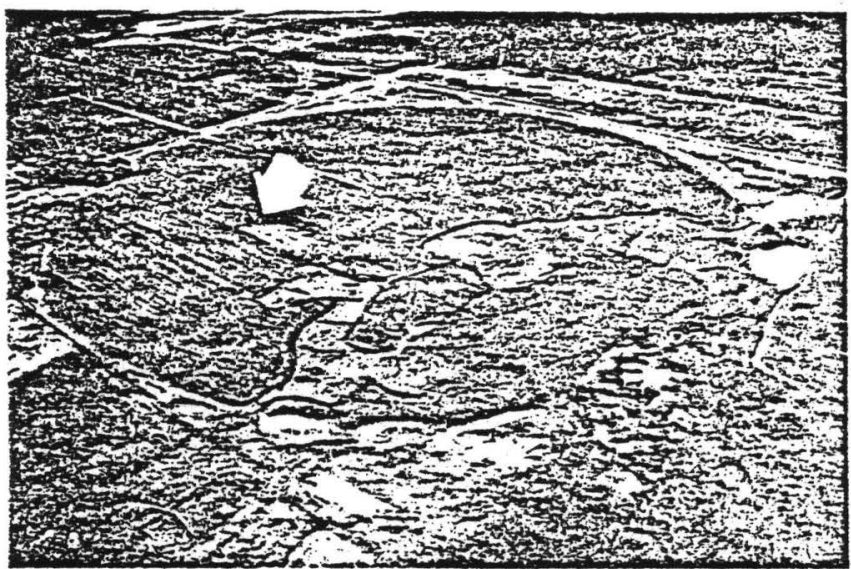

Gray area shaped like a pieslice on this circle of irrigated potatoes was found to be infested with wild oots. The infrared stide was used the following year to locate this weed infestation so that it could be treated with a siemical.

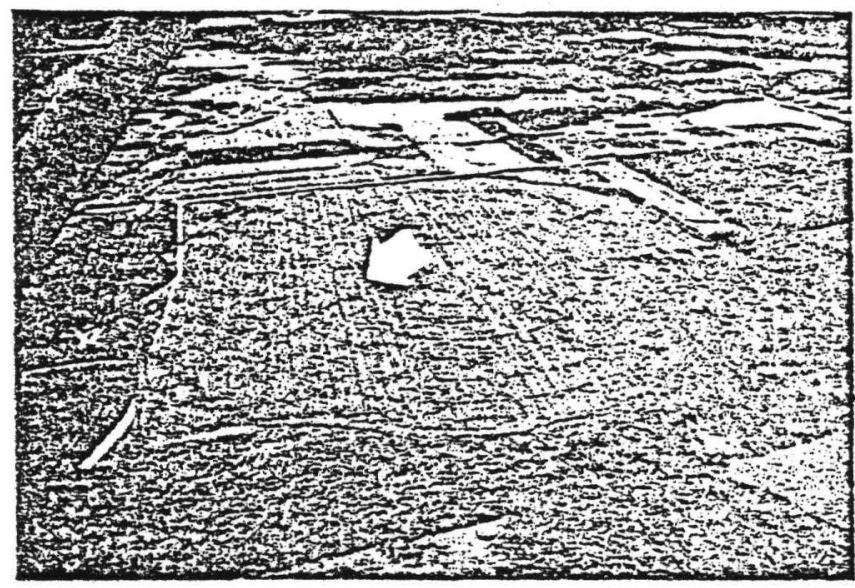

The streaking effect in this sunflower field was caused by a planter maifunction-one of the outside units on a 12.row planter wasn't working properly. Indicstes the need for some type of monitoring device on the planter.

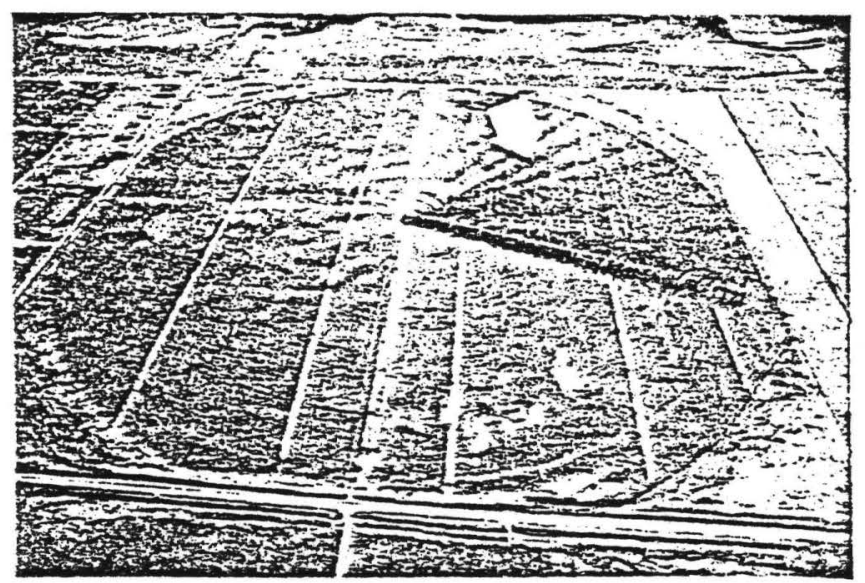

Darker lines radiating out from the center of this irrigated circte indicote that some areas passed over by the sprinkier are werter than others. Uoon closer investigation, it was determined that the irrigation unit was not moving a a uniform spead. 


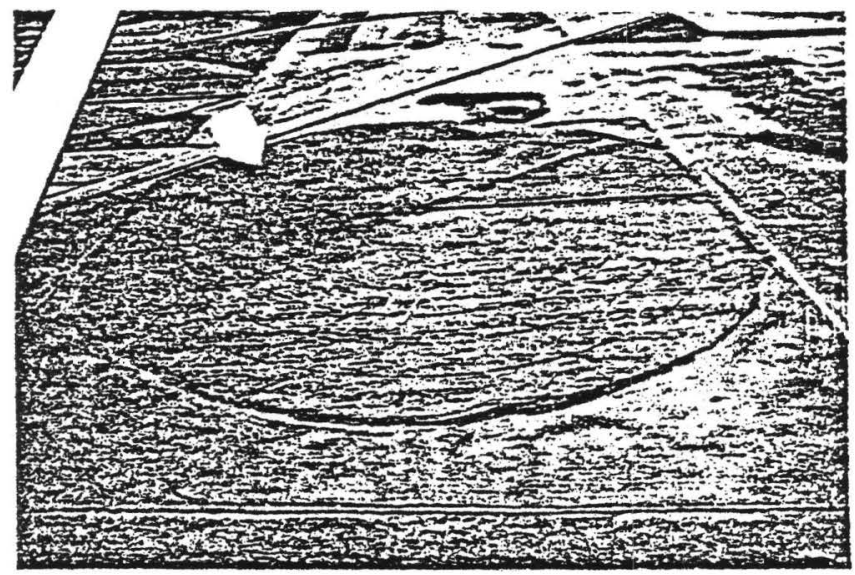

The darker red area on this irrigated eirele was investigated from the ground and was determined to be on excess application of ni. trogen. The irrigation rig, in applying the nitrogen, hod not distributed it uniformly ocross the entire cirete.

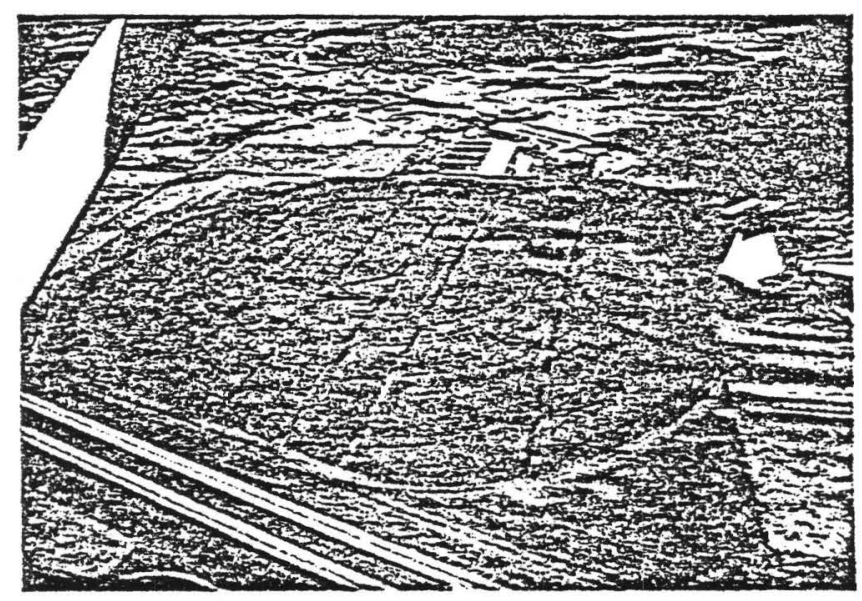

The dark ring just inside the perimeter of this circle of irrigated pototoes indicates a sprinkler malfunction. Upon claser investigation from the ground it was discovered that one nozzie was putting on less water then the rest, creating the ringed effect on the inirored stide. 


\section{A new twist sends old technique soaring}

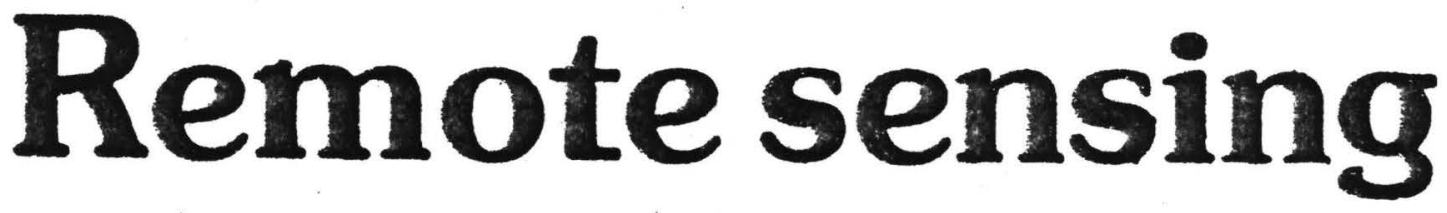

$S^{s}$ everal cowps and a tew larmers are yoing to the air to monitor their crops and rangeland using the rechnique known as remote sensing.

Acrually, it's an old technique with a new twist. A farmer may not think of it this way, but anytime he checks his crops or pastures by slowly driving past them on a summer aftemoon, he's doing remore sensing. To the experienced eye, there's lots to see-insect damage or ferrility problems may be showing, a weed parch may of getting out of hand, or the pasture overgrazed.

The same thing is being done from the air, with cameras loaded with or dinary black and white and solor films, or the special infrared and thermal films. Black and white photos have been used for years for mapping. The Soil Conservation Service likes to use phocos taken in the spring when the ground is bare and soil types show up well. The ASCS generally uses phocos aker. during the height of the growing season when fields stand out best.

On color infrared film heaichy crots show up a brighe red while less healthy crops are lighter. The advartage of color infrared is that crops under stress can be seen on the color infrared film much sooner than by the eye or regular color tilm.

A few farmers near Gettysburg, South Dakota, yot a look at their iri. gated croos last summer on infrared Film when the Potrer County Grain Co-op in Gerrysburg experimented with the technique.

The plane covered the tieids oniy once, but Mike Stewar, tertilizemanager at the co-vo, said the tarmers all tound the picrures informative.

"I can't say we came up with any remendous problems, but we did change some management prac. rices," Stewart said.

"But you gor to have the guy 'with. you who knows the field," Stewar added. "He can take one look and say-hat's where he forgor to turn on the anhydrous applicator, or where they mixed too much water in with the chemical.

This summer they'll try it again at Gettysourg, flying the fields twice-once in the soring shortly after the com germinates and again in August when heas and moisture stress should be at its worst.

One of the problems in using color infrared photography as an eariy de. tection technique is that although it's fairiy easy to get good pictures, it may take one to two weeks to get the film developed-10 late to do much help if the situation is critical.

Lute Amstrong at Full Circle, lac., in American Falls, Idaho, has solved that probiem by expanding on his photography hoboy and developing his own film.

Last summer the co-op took aerial infrared photos of 13 grower's center pivots every Monday morning. Armstrong developed the slides that. artemoon and by the next moming the prints were in the hands of the Full Circle field men.

"There were 2,300 acres that we covered in any hour that would have akken two weeks to cover with a fieldman walking them," Armstrong said. He figured it cost soout 12 cents per acre per'picture, alchough the co-op did not charge the farmers inyolved since it was par oi an experment. He added, though, that it would be nigher if the film was processed commerciaily.

Like everycody who works with inirared film, Armstrong emphasized that you can't iell exactly what's wrong by looking at the stides-but you can see that there's some sor of problem out there that has put the crops under stress. With the photo in hand, you should be able to waik directly to that spot and investigate the problems.

Armstrong said most growers were interested in their water management, particularly because of last year's water shortage. They also found ocher uses. Potato growers were able to spot early potato blight. "If we can treat the blight when it stars," Armstrong exolained, "'we can get two more weeks growing time on the pocaloes. The difference berween when the inirared picks up the stress and the naked eye is that two weeks."

Other uses of aerial photography for agriculture are being developed. There are places in Mlontana, for instance, where the terrain is so rough that large areas are totally isolated. Ranchers in Cascade County were having problems with leaiy spurge - a waist high weed with a presty yellow flower that has a nasty habit of taking over grassland.

The ranchers were spraying the weed, but had little success since weed seeds ware coming downriver from the isolated upper Smith River.

Cascade County oificials hired a consuiting service to get aerial color infrared photos of the isolated area and make a map of the weed parches. Je if Ryan, remote sensing speciaiist with the Ecological Consulting Service, of Helena, Montana, said the leary spurge showed up bright pink on the infrared film. They shecked their photography by tlying into the area with a helicopter.

It's believed about 80 percent of the leary spurge sites were located, Ryan said. Maos were rumed over to the county and this summer, county workers will soray the noxious weed. "The weed conurol people now have an idea where the probiem is and the size of it," Ryan said. 


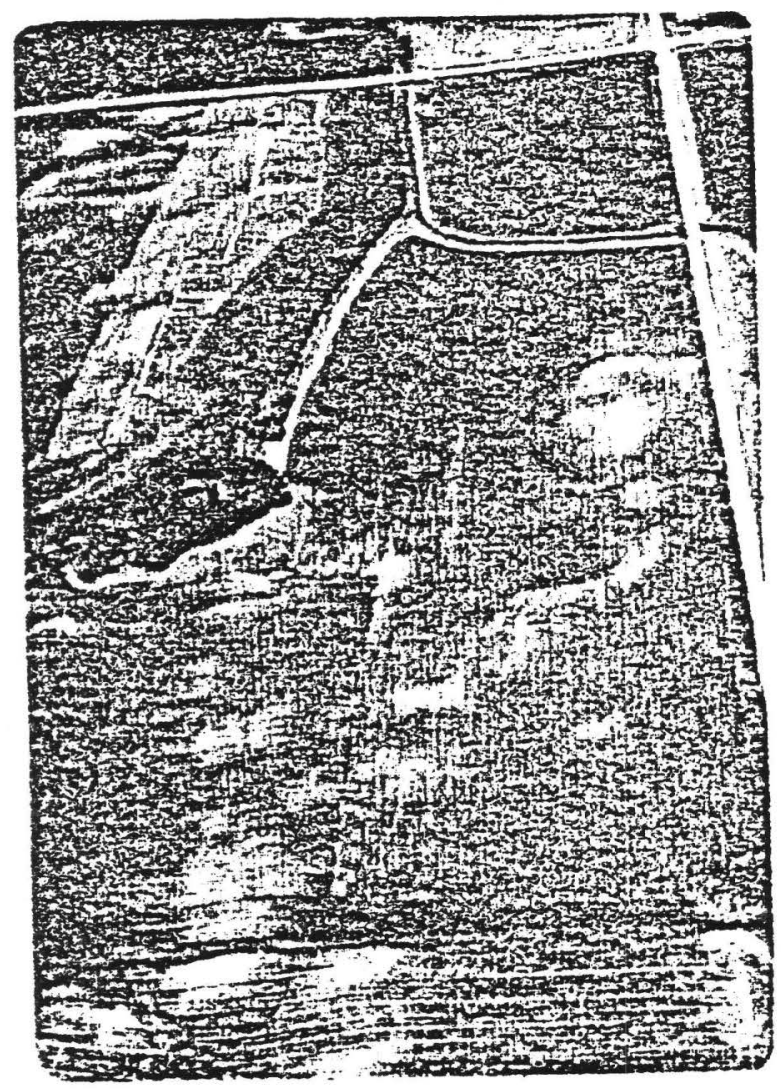

In the Red River Valley along Minnesora and North Dakoca's border, remote sensing is saving the sugar beet comps about $\$ 1.75$ million by reducing spoilage losses according to Don Moore, director of the South Dakota State University's Remote Sensing Instirute.

"We can use thermal scanning techniques tlying over sugar beet piles at night to detect where spoilage is occuring," Mtoore explained. "Then workers go out and section out those parts oi the piles."

Thermal scanning is also being used in experiments to derest the formation of saline seeps. "We're looking at the thermal spectrum because soils that are high in moisture content have grearer evaporation and are cooler," Voore explained. Next year, the joint project annong North and South Dakota and Wyoming will take a look at the microwave spectrum.

In Montana, Ecological Consulting Service has done experiments in using color inirared to detect saline seeps for the Montana Deparment of State Lands.
"Eighty percent of the time we cuuld see the entire seep mechanism at the high altitude of $\$ 0,000$ leet," said Bob Carroll. of the consulting service. Yet, he added that although the technique appeared to be successtul. he doubred it would ever be used on a starewide basis because of the cost. "It would cost probabily 55 million to Dly the entire stare of Montana and interpret the photos."

While remote sensing works well in some situations, Vferte Meyer, director of Minnesota's Ag Remote Sensing Instirute, cautioned that it won't always work. "A lot of times people think if they've got color intrared photos they can see everything, but a lot of times you can':."

Researchers at Minnesoca have been unsuccesstul in finding a system to spot Dutch eim disease that is etonomically teasible. They ve also tried detecring leari soot disease in sugar beets with linle success. By the time it showed up on color infrared film," Meyer said, "it was all over but the shouting."
An infrared aerial view showing how soil types affect crop vigor - the fields to the bottom and right are soybeans. The bright red strip is corn. Left of the corn is an oats field. Photo by Steve Sodeman, field agronomist for the Trimont (Minn.) Co-op As. sociation.
Uses of remole sensing in agriculture are just staring. Except in the ares of soil surveys, Mleyer said, "not that much has been done in applied agriculture. There's plenty of green fields for developing practical uses, and I would undertine practical. A Ior of these applications have to be worked out rather carerully, and you've gor to be tough on the dollar end. It's a prenty jazIy way to go, but if it doesn't pay-iorget it." 
Check

trouble

spots

with

inirared

\author{
by Gerald H. Smith
}

Consultant, Farm Management and Agricuttural Researeh. West Fargo. N. Dak.

During the fowizg season a crop is subject to many elements that can cause abnormal growrth of a piant in a beid. Intrared phocographs of fields can be used as an effective tool to identify that abnormal growith in small or large areas in the field.

The photograpis can be taken by anyone using a $35-m m$. camers with Ektachrome infrared film and a deep yellow $=15$ fiter. The airplane should fly at an altricude suftecient for the pho. tographer to cover the envire seid in quession. If the photographer's storaci can wolerate the motion, the piane can be tilted on its sice as it goes over the area to be shot. This technique gives a picture of the field that puts all areas of the fieid in proper perspective.

incerpretation of what is sen on the sibde becomes easier with experience; boweve:, the main object of taling the picture is to identify a problem winich shows up difierently on a slide than the normal dark red color seen in soure 1. Viewing a stide, it is diffeuit to identify a specinc disease or insect problem by looking at the slide alone, but the unbealthy plants will show a different color than the healthy plant, which is the inforsation a grower is seeicing. He can then pinpoint the lacation of the problem and insoect it in the neld and identify the cause of the poor growrh.

In figure 1 the red coior is uniform througiout tise seld with only minor ijorit spors toward the lower portion. The ligint spots are a result of coarser tercured soil or sandy ridges that are usable to hold the moisture and nu. vients to sustain the vigorous piant coorit seen throughout the remainder of the field.
Figure 2 has a uniform red color with the exception of planter skips (A) made from one end to the other. On the bot. rom side of the field the color of the plants changes to a lighter gray which didn't receive as much water and nitrogen as the remainder of the beld. This condition could be caused from over-planting the field boundaries, improper discrioution of the end gun or the influence of a prevailing wind. The large dark spots to the left of the center pivot are shadows from elouds. It's preferabie to take pictures from about 10 a.m. to 3 p.m. for good color develop. ment; however, that is aiso the same time when clouds form quite trequently durirg the growing season.

Cropping history has a deânite efiect on crops growing unde: irrigation on sandy soils and is more inporant with shallow rooted crops. The strips seen in froure 3 were com and alfalia the prior year. The residue from it bad a greater water and nutrient holding capacisy than soil around it.

The straight lines on the rigint system in figure 4 are oid roads and un. derground gas lines. The population is much poore: on the right system as compared to the left. Obcaining a good population is a paramount key to optring crop production under dryland or irrigation, but more so under iriga. tion because of increased production costs. A grower should evaluace every porrion of his planting operzicon, par. ticulariy concitions sutousding ger. rinstion and emergence to maximize the populacion in the field.

Irigation is the apolicarion of wate on a fieid in a unirom manner. A power purchesing a new systers or acpuiring land with an irrigation system on it should check the imoust and unifor. mity of water applied to the soil. New systems can have components installed incorrectly and old systerns develop problerns of wear and breakage trat can seriously affec: water distriburion. In figre 5, a ring can be seen about balf way to the center which goes around the fields in a circular manner. This ringing effect is commonly seen in fieids where the system was izmproperty nozzied. The result is roore water being appiled in one ares of a field than another. On the lower system, a saw-toothed edge can be seen on the lower lest side, which is the resule of an end gun malfunctioning.

In figure 6 , wasering lines can be seen radiating from the center pivot. Wacer. ing should be uniform as seen in the lower left portion of the eircle. The radiasing lines are a result of irregular zoverment of the system.

Intared photos are a good tool for an ingrator to get an aerial viex of the developmest of his crop. If a program is developed and followed, it forces the irsizatos to spend a given arrouss of irne on inspecting his roo roore trequeitly thas he may do if a definite program in't develooed. Each growe? inspects bis own fields in a different marner. Some do it at 5o mph from the picing, and some do it on the "tomorrow when I get riene" schedule. Needless to say, many problems can be deveioping in a field that borb of these metbods wouldn't disciose.

Walking through a field on a regular basis is a good babir to follow; however, aerial photos can reveal many more of the overall feld probiems thar grousd. leve! views don't. $\mathbf{T}$ 
Figure 2

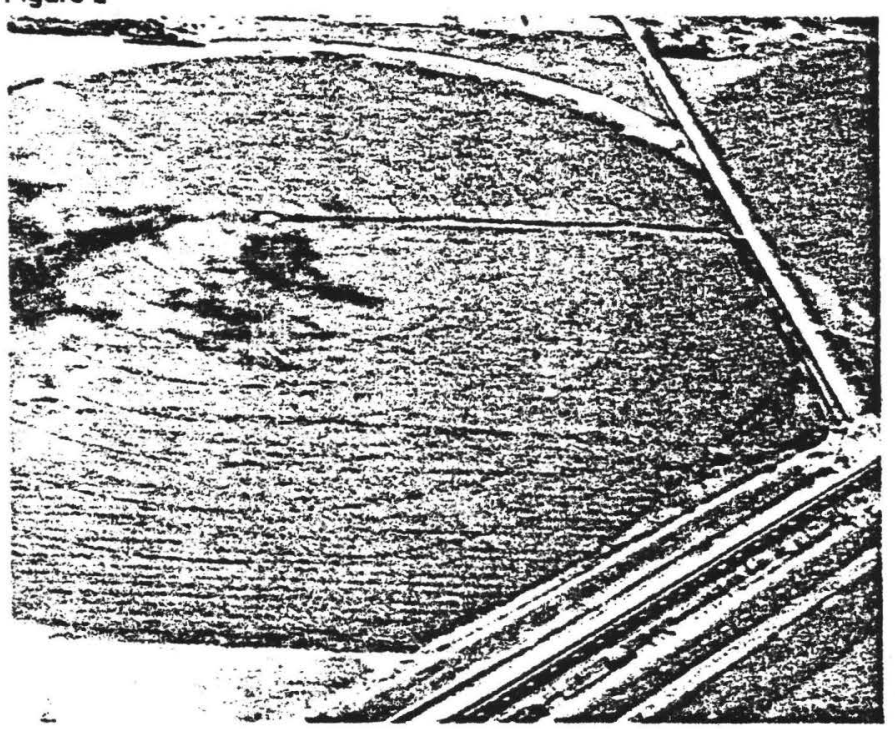

Figure 4

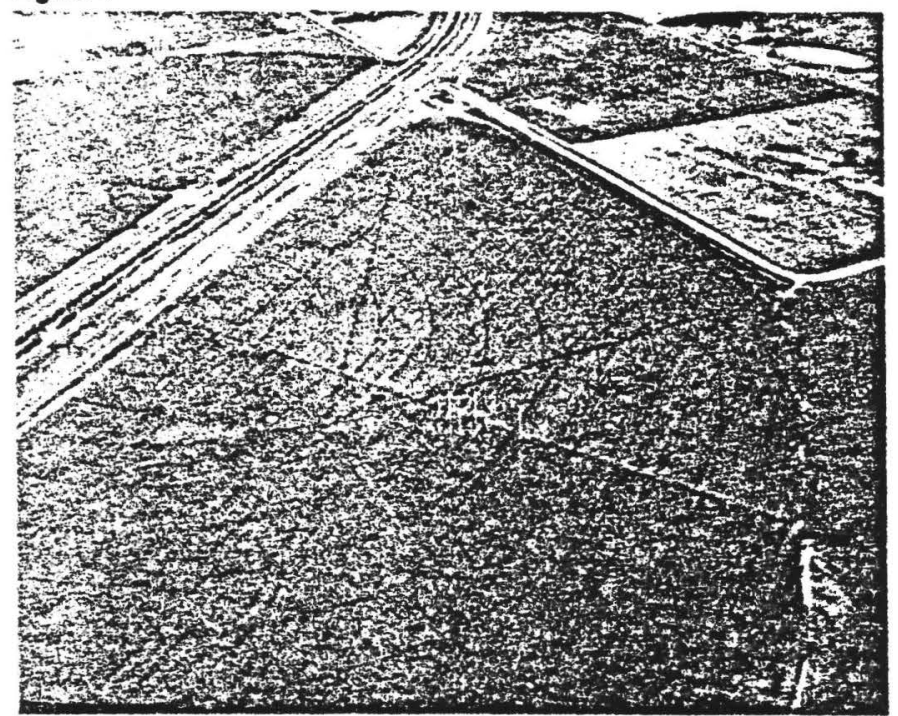

Figure 6

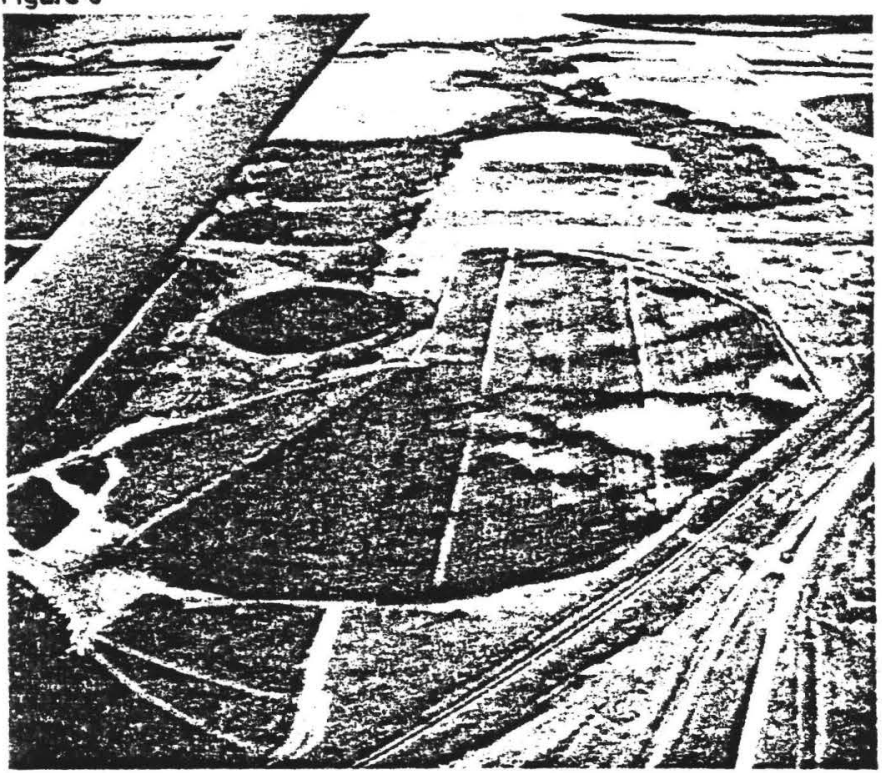

Figure 3

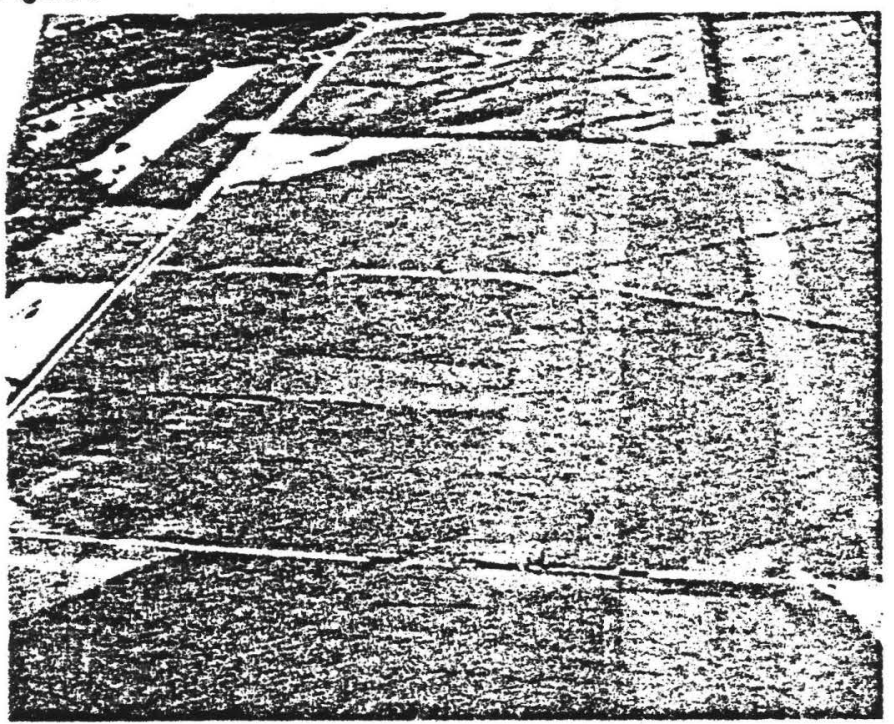

Figure 5

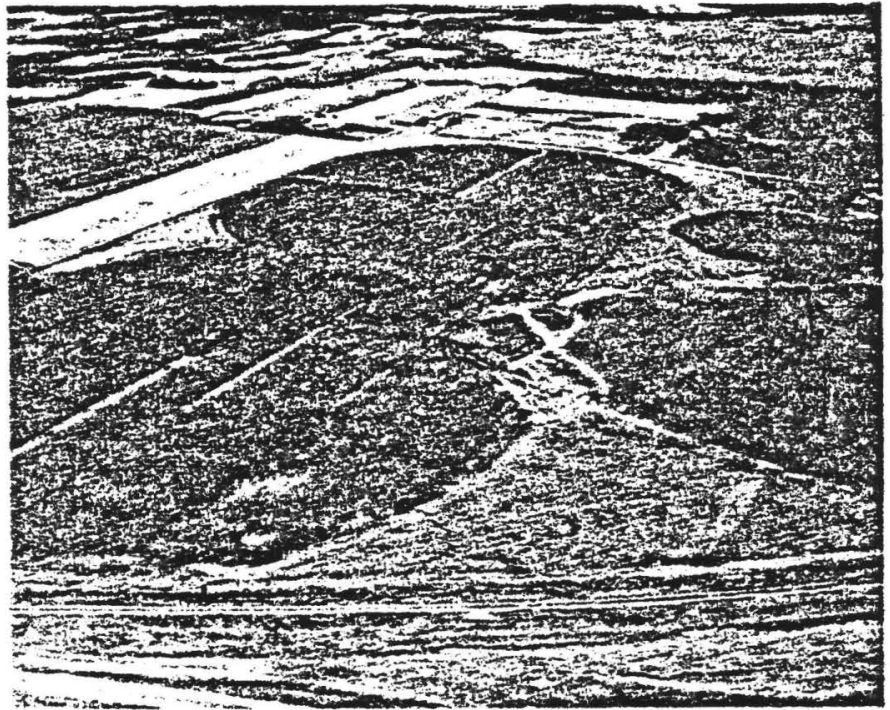

These six intrared photos illustrate a relatively new management tool that more farmers could be using. Farm management consultant Gerry Smith explains each abnormal area in the story on the facing page. A good aerial detectlve can see many problems that you can't see from ear height viewing.

Editor's note: Producers attempting to do their own aerial inspection of fields will find it increasingly difficult to use the ordinary $35-\mathrm{mm}$. camera as suggested in the article. Ektachrome infrared film in $35 . \mathrm{mm}$. size has not been upgraded for Kodak's new E-6 processing. So producers in certain areas may not be able to find the film or a processing plant to handle it. Infrared film will remain available in $70-\mathrm{mm}$. size, used in aerial cameras and specially processed. 


\title{
It's Time to Consider Aerial Biosensing
}

\author{
This new management tool using color infrared photography \\ offers a way to save time and money with quick and accurate \\ identification of crop problems.
}

D ETECTING a crop in stress by taking its X-Ray from a plane? It may sound like magic, but aerial biosensing, or color infrared photography, is definitely scientific and backed by believable results. Offering this accurate technique as a service can give you a space-age edge on identifying and solving many crop problems not seen on the ground.

Although an innovation going back to the days of astronaut Wally Schirra. color infrared photography has only rather recently been applied as an ag- ricultural management tool. It is now being used to monitor pest attacks, fertilizer applications, growth patterns, water distribution, even to check for soil variations and equipment failures.

As one photographer illustrates. "Typically a farmer growing field corn will have us shoot the field three times a season. The first shot is when the corn is in the 6-8 leaf stage-to get an idea of what his stand is like."

$\mathrm{He}$ added that this first shot would show germination problems, irriga. tion patterns, and herbicide and fertilizer uniformity. The second shot would be taken during the critical state of silking and tasseling to detect crop stress. "If you put a crop into stress then at silking and tasseling, you can have a loss of $40.60 \%$, so we are very interested in moisture stress at that time. We make sure he's getting his water on right and that sort of thing."

The third shot would be taken at crop maturity - this is what helps the grower make some decisions about

Contrast normal color print (at right) with photo taken using color inirared photography. Note the greater detail available in the photo below.

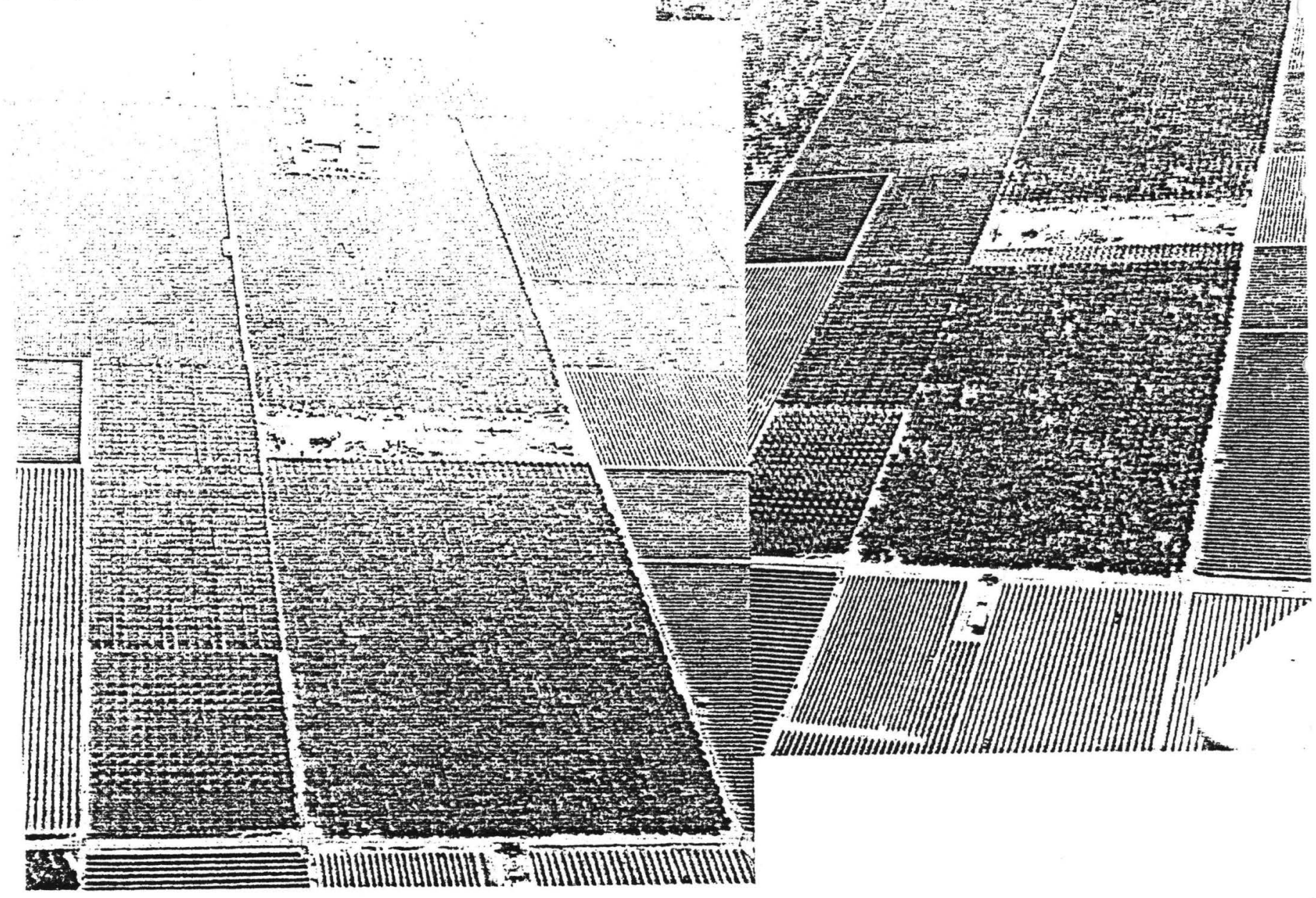


which fields to pick first and how much moisture can be tolerated.

Color infrared film (not to be confused with thermal infrared) is a false color film that shows living healthy vegetation in red. The aerial view gives a perspective, obviously, not possible from the ground-showing actual shapes and patterns which can be scientifically interpreted as being caused by specific events such as pest attacks, faulty equipment, sloppy application, etc. It reveals things that the naked eye cannot see.

\section{How It Works}

According to Omax Biosensing, Omaha, NE, what the method does is to catch the reflective light from a green leaf above and beyond what can be done with natural color photogra. phy. Plants reflect over $40 \%$ of the infrared light that strikes them as com. pared to only $8 \%$ of the visible light striking them as seen by the eyes or natural color photography.

There is a better chance that even the smallest changes in a crop will show up with infrared, compared with normal vision and photography. Practitioner Richard Bigler of Richard Bigler \& Associates, Del Ray, CA, who began working with infrared at its earliest stages explains that infrared "helps you to see problems before you can see them with your normal eyes. It allows us to look into the plant, and see a problem, and correct it before it becomes disastrous."

The method is not some sort of modern day quackery. The practitioners take their efforts seriously and discourage any lack of professionalism. In 12 years of photographing, Bigler has personally invested "tens-ofthousands of dollars" on research and equipment which enables him to confidently claim "no one gets the color resolution I get." His \$8000 Hasselblad, $70 \mathrm{~mm}$ camera was especially modified at Zeiss, Germany for infrared with his own design specifications. He has also designed his own filters and lenses and has been known to spend $\$ 3000$ on just one lens.

Using a Cessna designed with a special mount for the infrared cameras, Bigler operates up to three cameras at one time. He has the pilot first climb to 10,000 feet, then descend to 3500 feet. Using $21 / 4$ film he shoots about 70 photos and has them processed in Los Angeles according to his own specifications.

Another photographer, Jim Baber of Omax Biosensing in Omaha, NE, points out that infrared is a specialty business. He flies in a Cessna 210 with a camera mounted in the belly and takes only vertical photography for interpretation purposes. Although Baber says some people shoot out the side window, he emphasizes that this is not the way to go for good results.

Baber, though contemplating in- vesting in a $70 \mathrm{~mm}$ Hulcher, uses a $35 \mathrm{~mm}$ single lens reflex Nikon with motor drive that automatically prints the date on the slide. He admits that any good photographer could research the infrared technique and shoot his own pictures, but notes there are some important technical aspects that must be observed: "We can only shoot from about 10 in the morning to about 3 in the afternoon. We have to shoot when the sun is about $20^{\circ}$ either side of the zenith. If it gets any lower than that in the afternoon or higher than that in the morning, there would be too many shadows and you don't get the right kind of reflections off the crops.

"This film is very heat sensitive," he adds, "so we take it out in the field in a deep freeze, very close to $30-32^{\circ}$ inside, on the morning we are going to fly. As soon as we load the camera we shoot it and as soon as it is shot, the film goes back in the ice chest." Baber stresses that the photographs he has seen by those who haven't taken special precautions have been very disappointing and distorted in color.

\section{Service Made For the Dealer}

Infrared offers the dealer a unique way to help his growers scientifically manage their crops. By lining up a good photographer who is a good film interpreter (or who has one working with him), the dealer can save time and money for his customers-and improve his own professional reputation.

There's no need to be involved with the flying, photography, or interpretation. Infrared can be offered as any other service would be-as a tool to help the grower do his job.

Chemical dealer Marvin Meyer, Fer. tilizer Service Co., Inc., Sidney, NE feels that -Infrared in my opinion is one of the best management tools to come along. I think probably one of the biggest helps that I've found from it is that we can use this in soil sampling. With the infrared photos we can narrow down the problem areas in the field... and of course those are the areas that actually cut our yields any. way.

"We use the infrared photos as field maps and can save an awful lot of time by pinpointing the problem areas, sampling them, and finding out why they're different from the rest of the soil in the field. We can work on those spots and if we get the soil built up to produce like the other ground why then it is really worth the expenditure the farmer puts out."

Fertilizer Service Co., Inc. has been offering infrared for just one year, but already Meyer can see the demand for the service is increasing substantially. Much of this acceptance is due to word-of-mouth grower approval.

Hollis Miller, Miller Seed and Sup- ply Co., York, NE indicated that infrared more or less sells itself-when people see the results they go ahead with the program.

Miller also points out that on the whole, this service is profitable. "It is a benefit to the grower, and anything that benefits him is bound to benefit a dealer."

Developing a feasible and afford. able program for the grower can be approached in several ways. Richard Bigler notes that the cost is related to acreage-the larger the acreage, the better. He's been able to photograph 10,000 acres for as little as $15-20$ cents an acre. For the typical grower of 1000 acres or less, he has provided service for $\$ 500$.

Bigler says that "Under ideal farm conditions with a good grower, we might oniy have to look at a field once a year; twice a year at tops." There are some crops, however, that demand a closer watch. These crops may be checked from the air up to three times. Of course, any extra problems-such as an unexpected pest attack - might require extra runs. Bigler says that although the time needed to shoot the film, process it, and send out the written report to the client usually takes about a week, in serious conditions where time is crucial, reports can be completed in two days.

In working with dealers, Jim Baber requires a minimum of 1000 acres to be photographed. "The cost is not justified for anything smaller," he ad. mits. The dealers line up either a good sized grower or many small farmers. He has had the most success with the second alternative.

If the dealer can line up 10,000 to 15,000 acres he gets a price break. Baber explains. "We have situations going now that range from $\$ 1.25$ an acre down to 22 cents - it just depends on how many acres are involved.'

After the dealer has lined up the acres, then Baber takes a mobile unit and technician to the area. About three times during the day, he will drop off film at the mobile unit for processing. There is a one-day turn around for viewing the film. Returning home with duplicate photos, Baber leaves them with agronomist Dr. Dale Flowerday, University of Nebraska, Lincoln NE, who gives a tape report of what he sees. The cassettes are mailed to the dealer within $4-5$ days.

Although many dealers get $20-25 \%$ for promoting the service and lining up the fields, there are other approaches. Marvin Meyer offers a complete package-takes soil samples, sends them to an independent lab, gets the results and programs fertiiizer applications, herbicides, insecticides, and sets up the infrared photography-all as part of his consulting program. He pays the infrared 
In California's Imperial Valley, citrus trees near water pond show salt damage created by plugged leach lines.

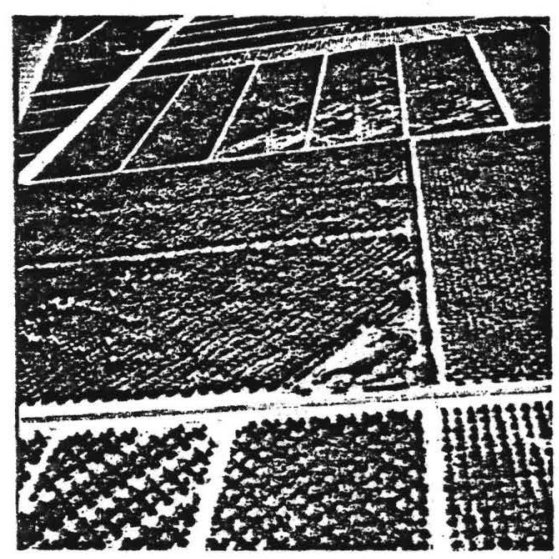

photographer to take the pictures and passes the cost onto the grower as part of the consulting service.

Mever illustrates, "Say their fee is $\$ 2.00$ an acre. I figure my fee is $\$ 2.50$ an acre. That gives me 50 cents an acre for my time, the cost of the soil samples, and everything like this. It really isn't a money making operation-it is just providing a service. ... The main thing is to work directly with your growers. I feel with a program like this we can provide them with a good service.

"Now, not everyone takes us up on it. And they don't have to. If a person came in and didn't want any infrared photos, I would still do all the programming and everything."

Not all dealers, according to Jim Baber, are charging for the infrared service. "We have some chemical dealers who are doing that just to in. sure their place in the market; to show they have leadership in the area," he said.

\section{Room for Innovation}

Promoted in the usual mannerthrough radio and newspaper adver. tisements, grower meetings, and word-of-mouth-it is a service that is so new that there is a lot of room for innovative marketing.

There are some limitations that must be considered. Confusion stemming from a basic lack of understand. ing of the techniques involved has sometimes made growers and farm advisors skeptical of its worth. This confusion combined with some irresponsible and overzealous statements as to what it can do, has given infrared a slow start-in spite of the fact that dramatic and accurate value is often realistically possible.

One example of irresponsibility on the part of an over-enthusiastic photographer was reported to Meyer. A grower told him how a photographer monitored his corn and advised him

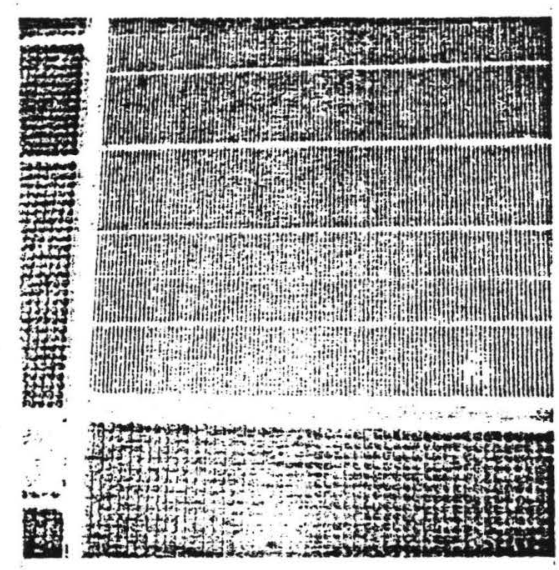

Note the aimost immadiate radiant red color change in grapes that have aiready received isrigation water.

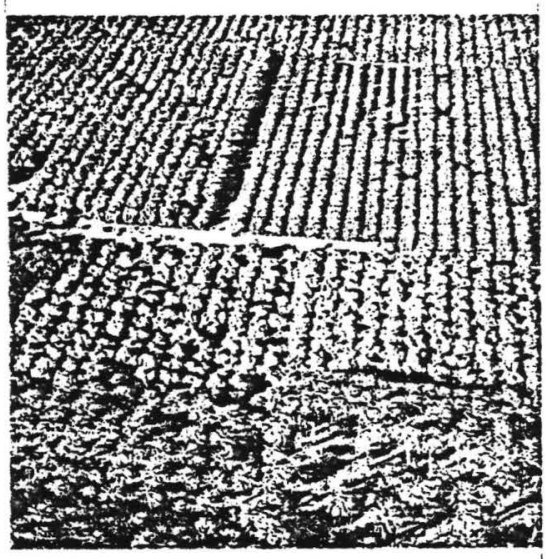

Variance in growth in orchard from age of trees and orchard management are caught on film. The dead block of trees resulted from applica. tion of incorrect pesticide.

\section{All photos courtesy Richard Bigler}

that one particular hybrid was worthless and two other varieties were going to really out yield it. "It happened to be in an area," continues Meyer, "where there was a bad infestation of a bacterial wilt. The one that the photographer said was a failure was the only hybrid left standing in the field.

"This is why I say-don't make statements unless you know what you are talking about and can back it up!'

One infrared specialist has found a reluctance on the part of some to accept the concept because it is too accurate-it shows up sloppy and careless applications. He em. phasized, "A guy that's farming for an absentee landlord-when they see that film. they darn near freak out, be cause it shows every mistake that they've made."

\section{Where It Can Go From Here}

Most of the true believers in infrared. however, are convinced it will eventually get off the ground.

Hollis Miller explains. "The people
Center field shows poorer plant growth caused by changes in the soil protile.

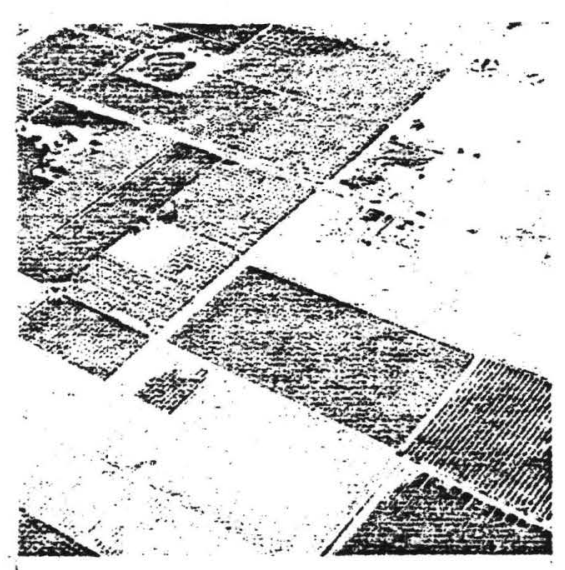

who are using pest management are continuing to stay with it because they feel like it's paying them. The same thing is happening with infrared-we are having people staying with it too."

"I see an enormous future for it," says Richard Bigler. "If you're just one person running around the field try. ing to find out what's going on. and you've got 2000-3000 acres-how long is it going to take for you to find out? With infrared, you can find out and have an accurate, scientific answer in two days."

As Marvin Meyer points out, "I think probably that infrared monitor. ing might be just the start! A lot of things might come up in the next few years.'

Some of these advancements have already begun to take shape according to Jim Baber. "The future really lies in new technology. Line scanners, for example, have a lot more capability. Instead of recording a field photographically, you record electronically, on magnetic tape."

"Right now the only people working with these things are research organizations like NASA," he adds. "But, I feel that at some point in the future-who knows how fast technology is going these days-maybe $j$ years, maybe 10 years, we'll have line scanners and we will be able to measure fields electronically."

Infrared isn't the panacea for everything, but used as a management tool it can be effective. Like all tools, get. ting the most from it depends on what you put into it.

By contacting Aerial Biosensing Association $(A B A)$, a new organization to encourage professionalism in photographing with infrared, the dealer may get a good idea of what to expect from photographers and interpreters before he gets involved with them. Vice-president Cal Kuska can be reached at Aerial Biosensing Association, 1300 City National Bank, Omaha. NE. 
What

infared

photos

can tell

you

by Joe Isakson

NEED A crop management tool that will let you look at a lot of things in your fields in a hurry?

If so, consider infrared photography, or aerial biosensing. It lets you see the total picture of your fields and crops from the air in a single image. Aerial photographs may be used as follows to aid in crop management.

- Preplanting-to determine field surface conditions and cover. Good also for obtaining soil pattern information.

- Emergence-to check germination and possible problems with insects, disease, weeds, or equipment failure. Photos can help make replanting decisions.

- Mid-growing season-to check stand growth and development and plant loss from adverse moisture, disease, etc. Also, to monitor forage availability in rangelands and water distribution by irrigation systems.

- Preharvest-to check for lodging, weed infestation, uniformity of ripening.

- Post-harvest-to check field cover in harvested areas for weed and volunteer regrowth patterns.

- As required otherwise-to document special situations, such as floods, tornadoes, hail, drouth or other damage.

This added crop management tool is not a pie-in-the-sky idea. Nor is it anything new. But the past year it found greater use in the Midwest and more producers now are saying they want pictures of their crops this year.

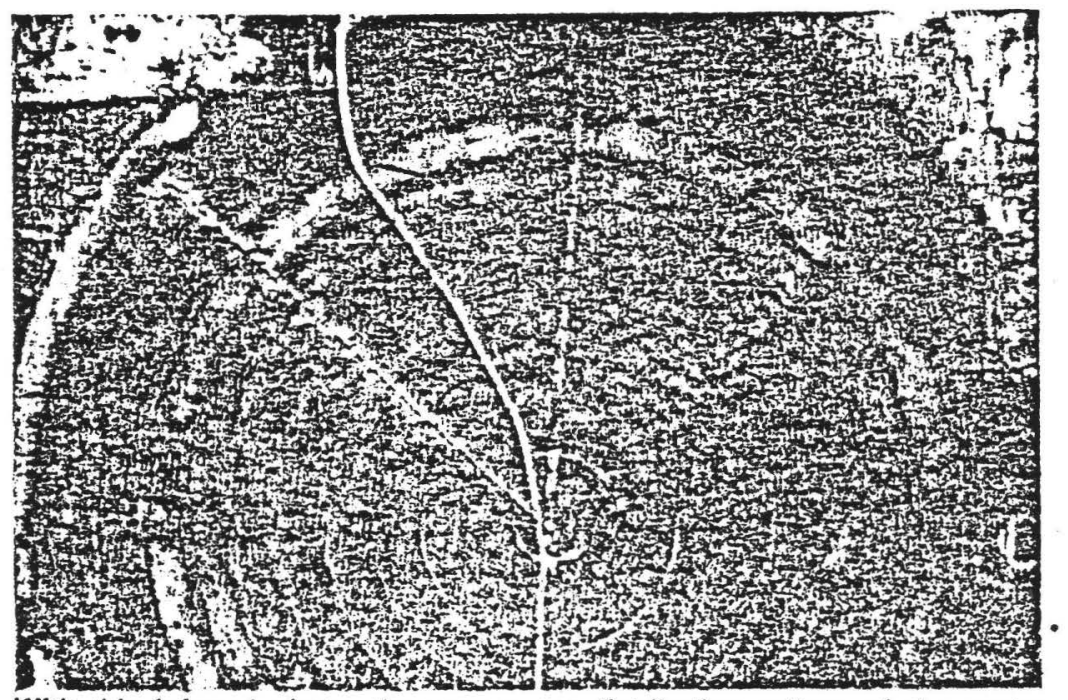

With this infrared photo, the poor water distribution pattern of the centerpivot system was detected and the malfunction of the system corrected.

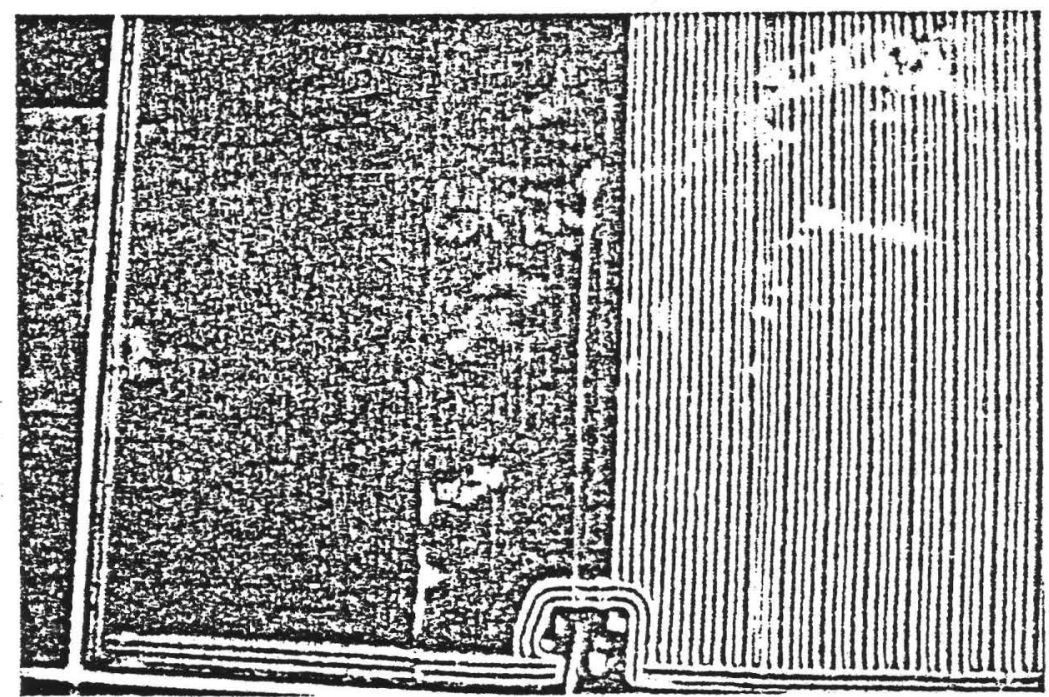

Drainage problems and soil-type variances are highlighted in this photo of

a non-irrigated field. Photo was valuable in making tile drainage decisions.

Infrared monitoring works because it's like $\mathrm{x}$-raying a plant, explains a spokesman for Omax Biosensing, Omaha, NE, a company formed to provide aerial infrared crop monitoring service to producers through chemical and irrigation dealers. Infrared is reflected from the leaf's interior and the slightest difference in crop reflectance indicates that a change is taking place in the plant.

If you can spot this change quickly enough, you may be able to save a crop, report officials of Aerial Biosensing Assn., Omaha, a group formed to promote this method of management.
With some of the bugs being worked out of the procedure, so that producers can see results of field photos more quickly, along with expert interpretation, infrared photography will have real possibilities within the next three years or so, a University of $\mathrm{Ne}$ braska agronomist believes. Dr. Dale Flowerday adds, however, that it will not replace soil testing or field monitoring.

And, within a few years, believes Flowerday, producers may be going more to heat sensing, rather than infrared, to detect crop conditions. "Today, heat sensing requires a $\$ 50,000$ machine, a television screen and a 
tape to run it from," he explains. "But, someday, a simpler system may be developed."

An important benefit of infrared photos is that they can show that management errors you've been making in your fields are adding up to a lot more yield loss than you may realize.

A Canadian photographer, Mack McKinnon, who runs Prairie AgriPhoto, Carman, Man., says that what may be judged from the ground as a few bad patches may show up as 20 to $40 \%$ of a field when viewed in an infrared photo.

McKinnon charges abour $\$ 40$ to take an infrared photo of one square mile of land and $\$ 6$ for a print from the film. One spring, he found that severe crop damage in part of a sugarbeet field turned out to be caused by wireworms. The farmer still had time to control the insects. and replant the damaged area. Another farmer discovered early that his oats field was heavily infested with thistles. He decided it was best to plow it up for summerfallow.

Photos taken in the middle of the growing season usually are too late for corrective action that year, but they can be useful in planning a better management approach the next year.

\section{Verifying the work}

Another advantage of photography is to verify work quality of farm employees: One large operator let some of his farm help go after studying photos of his fields. And, thanks to photographic evidence, he also is negotiating with a commercial chemical applicator for a lower price on a job performed.

You can turn that evidence around, too, and use it to show a customer how good a job an applicator did.

Dr. Vernyi Pederson, plant pathologist at North Dakota State University, advises farmers to get acquainted with their fields and know what they look like from the air. Then they can look at photos and be better able to. pick out anything different or unusual.

"But, as far as picking out a disease early, just from photo-

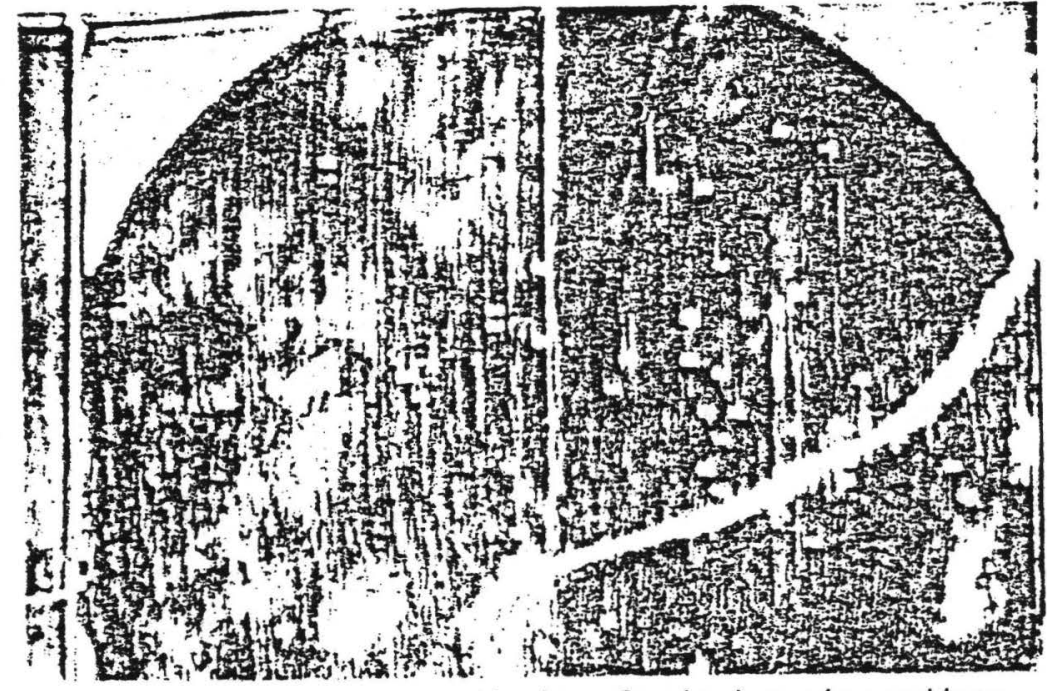

Planter problems were evident in this photo. Streaks show minor problems. while white spots indicate where entire planter was inoperative.

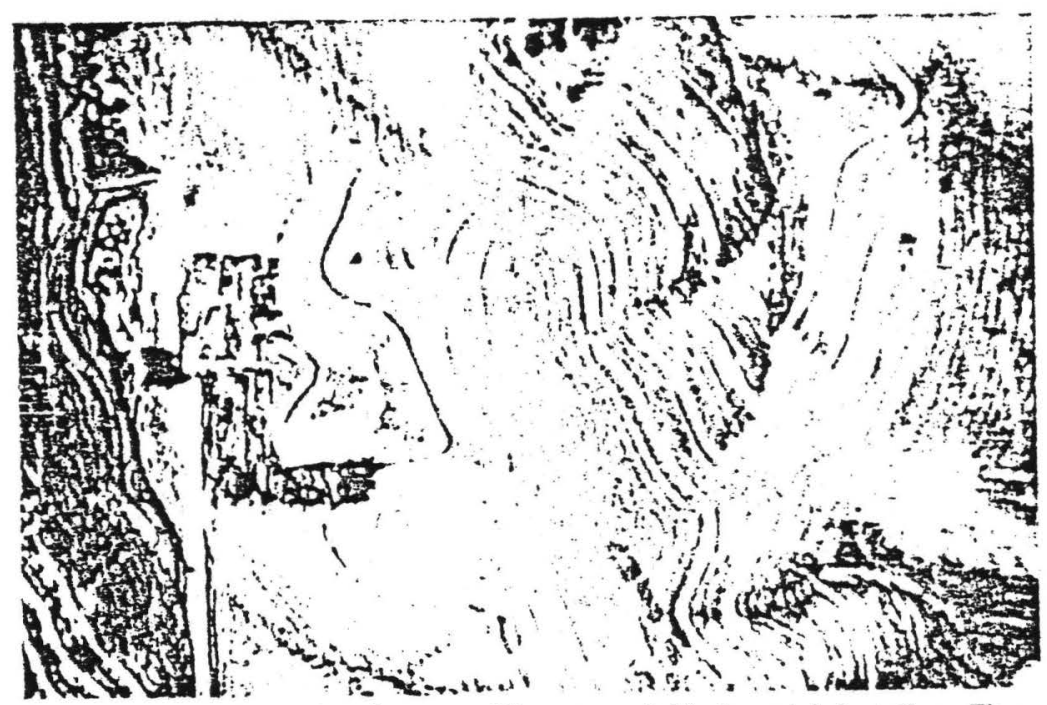

This late-May photo pinpoints specific areas of bindweed infestation. The farmer was able to spot-treat the areas, thus saving herbicide costs.

graphs, a producer would really have to know the history of his fields," states Pederson. "Knowing that, he could say, 'That's a draw that runs through there, or that's a high-alkaline area, and that's the way it always looks:' The key is to really get acquainted with your land."

What do crop consultants think about infrared?

Ed Lloyd, founder of Agyise, Inc., a Northwood, ND consulting firm, sees it as simply a tool with some pitfalls attached. "I guess that's why I don't hoorah it," he states. "It looks so good in color in a magazine that it almost looks too good to be true. It's a matter of interpreting it, and you have to know how to interpret infiures.
Lloyd feels that using color film, along with infrared, would be ideal. But this also would be twice as expensive. He advises farmers to work with someone who knows how to interpret the film.

Lyle Ross of Ross Farm Business Service, Alexandria, MN, who has just gotten into using infrared with a few area farmers, sees it as a growing management tool. "The farmer's sins are right out there in front of him. If he wants to make a profit on fields, he will look at his sins (with infrared) and try to correct them," he comments.

"Infrared has been lying there, ready for us.", hut only now has 
the time come to use it, as producers are looking for finer points. to increase and maintain production," adds Ross.

A farmer-inventor from Pope County, MN, Clint. Welti, owner of Welti Enterprises, which builds center-pivot irrigation systems, has modified his airplane and photographed some 200 pieces of land in his area in preparation for anticipated contract work with area irrigation farmers.

$\mathrm{He}$ feels that, with the aid of an agronomist, he could photograph up to 200 farms next summer and make "for the farmers a pile of money, because there's a lot of information that could be learned-from it." 


\section{Why not take}

your own aerial photos?

\section{by Hal Werner}

University of Minnesota Extension Irrigation Engineer, Staples, MN

IT'S POSSIBLE to take your own infrared photographs. About all the equipment needed is a camera and a small aircraft.

If you're lucky enough to own your own aircraft, or you can

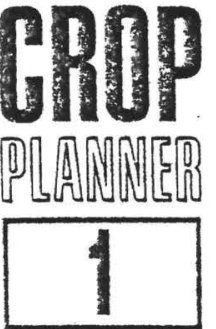

utilize your neighbor's, only a minimum investment is required for the remaining equipment. However, if you don't own an airplane, the cost of flying service is likely to be the largest part of the total cost.

A $35 \mathrm{~mm}$ camera commonly is used to take aerial photos. A single-lens reflex (SLR) type with an internal light meter is best. Desirable shutter speed settings are from $1 / 125$ to $1 / 500$ of a second.

The camera lens must accept a tilter. A Wratten \#12 (yellow) filter is recommended by Kodak for use with their Ektachrome color infrared film.

Even though black and white infrared films are available, solor infrared is recommended for uses discussed in this article. The Kodak film is similar to Ektachrome slide film. Sensitivity of the film has to be controlled to photograph reflected infrared sunlight (represented by red colors on the iilm).

Careful storage of infrared film is necessary to maintain quality. Don't use outdated film. Storing in a refrigerator until use is a good practice.

\section{Film processing}

Film processing should be done as soon after exposure as possible. If the photos are used for dynamic analyses, such as for weekly interpretation of crop problems, a processing lab that offers fast service (one day) is needed to insure timely information. Some commercial labs may not process infrared, so arrange to take corrective action in time for processing before taking the photos. Home processing also is possible.

If infrared film and processing are not available, standard color slide film offers a good alternative. Since infrared is not magic. the discerning eye may be able to see as much using standard color.

Aerial photos need not be taken vertically but should include coverage of the entire area desired. With standard $35 \mathrm{~mm}$ camera lenses, aircraft altitude will be about $3,000^{\prime}$ to obtain coverage of a quarter-section of land.

Exposure settings can be determined by experimenting or by using the camera light meter (as prescribed in film directions). Avoid taking photos through aircraft windows or with other obstructions in the field of view.

Best time of day to photograph is between 10 am and $2 \mathrm{pm}$ on cloud-free days. Cloud shadows make photos useless for interpretation.

In viewing the color slides, as a number of farmers in Minnesota and the Dakotas have done in recent years, a panoramic look at an entire field is possible. Subtle differences that may not be visible from the ground will appear on the photos.

In general, healthy-growing crops appear red on color infrared film. Each crop may be different. For example, alfalfa normally has a brighter red appearance than row crops such as corn or sunflowers.
Variations in color and tones on the slide indicate differences within the crop. These differences could result from one or more of the following:

- Crop itself. The crop type, va= riety and maturity generally contrast on the infrared slides.

- Souls. Differences in soil types and slope, along with drainage or lack of it, are evident, especially at certain times of the year.

- Cultural practices. Old field boundaries, row spacing and tillage practices will show on photographs. Equipment problems. such as planter and sprayer skips, also are easily detected.

- Fertility. Differences in fertilizer treatments or application problems can be identified.

- Pest problems. Spotting weed, insect and disease infestations before they become uncontrollable is a valuable use for infrared.

- Soil moisture. Using aerial photos to assist with irrigation can be helpful. Moisture stress or irrigation equipment problems can be identified.

Learning to interpret the photos is the key to success. Some interpretations are easy to make. But an experienced interpreter may be needed to determine some of the causes of differences on photos.

Many things influence how a crop appears on a photo. And, without experience, you may conclude only that there is a problem. Field checking on the ground is essential in pinpointing the actual problem.

Remember, too. infrared photography is only a tool, not the solution to a problem.

THE FARMER, January 20, 1979 


\section{Infrared film for aerial photography}

by William $\mathrm{H}$. Anderson

Applications Scientist, EROS Data

Center

Considerable interest has developed recently in the use of aerial photographs for agricultural management.

Even the simplest hand-held aerial photographs, especially those taken with color-intrared film, often provide information not ordinarily available through routine ground observation. When fields are viewed from above, patterns and variations become more apparent, often allowing problems to be spotted which may otherwise go undetected.

Once a potential problem has been discovered through airphoto interpretation, the site can be visited on the ground where an exace diagnosis of the problem can be made and appropriate management action decided. (Some examples of the use of aerial photographs in agricultural management are summarized in the accompanying table.)

Practical experience has shown that color-infrared film is usually best for agricultural aerial photography. Al. though color-intrared film has been available since World War II when it was known as "camouflage detection film," many people are unfamiliar with its somewhat unique characteristics.

Mose of us naturally tend to associate the term "infrared" with heat or temperature. This leads to the misconception that color-infrared film records the temperature of objects in the scene.

Technically speaking, the term "infra. red" can be used to describe a large portion of the energy spectrum including boch heat and nonheat portions; but photographs caken with coior-infrared film essentially have nothing to do with heat or cemperacure measurement. Ac. tually, color-infrared film is very similar to normal color film except that its sensitivity to light has been extended slightly beyond the visible portion of the spectrum and inco the infrared region.

Both normal color film and color. infrared nim consist of three separate layers of photographic emulsion on a clear film base. In normal color film, one emuision layer has been made sensitive to blue light. one to green light. and one to red light. The images recorded on the three emulsion layers of normal color film combine in the final image to form colors which closely macci those of the original subject.

Color-infrared filn, somerimes re-

Figure 1
NORMAL COLOR FILM COMPARISON
\begin{tabular}{|c||c|c|c|}
\hline $\begin{array}{c}\text { Film Sensitivity } \\
\text { In Emulsion } \\
\text { Layers }\end{array}$ & $\begin{array}{c}\text { Color On Photo } \\
\text { After } \\
\text { Processing }\end{array}$ & $\begin{array}{c}\text { Film Sensitivity } \\
\text { In Emulsion } \\
\text { Layers }\end{array}$ & $\begin{array}{c}\text { Color On Photo } \\
\text { After } \\
\text { Processing }\end{array}$ \\
\hline BLUE & BLUE & $\begin{array}{c}\text { BLUE LIGHT } \\
\text { Blocked by Filter }\end{array}$ & BLUE \\
\hline GREEN & GREEN & GREEN & GREEN \\
\hline RED & RED & RED & RED \\
\hline
\end{tabular}

Figure 1-Film sensitivities and final image color of normal color and color-inirared film. Notice that color-intrared film is aiways used with a filter (yeliow) over the lens to prevent unwanted blue light from reaching the film.

Figure 2-Low-altitude 35- $\mathrm{mm}$ color-intrared aerial photograph taken in mid-July 1969 of a field of recently emerged corn in southem Wisconsin. Heavy pains had fallen a few days betore this photegraph was taken, and standing water can be seen at $C$. The better drained portions of the field (A) appear in light tones. The somewhat poorly drained portions of the field (B) appear as dark tones. Test auger borings in the light toned areas (A) indicated four feet of silt over sand and gravel as compared to an average of eight feet of silt over sand and gravel in the dark loned areas (B). As can be seen, a timely aerial photograph can be used to heip determine the soil moisture capacity patterns of individual hietds. Compare this onotograph to figure 3 which was laken of the same fleld later in the growing season. It shows very dramatically the effect of soil moisture capacity variations on crop growth and development.

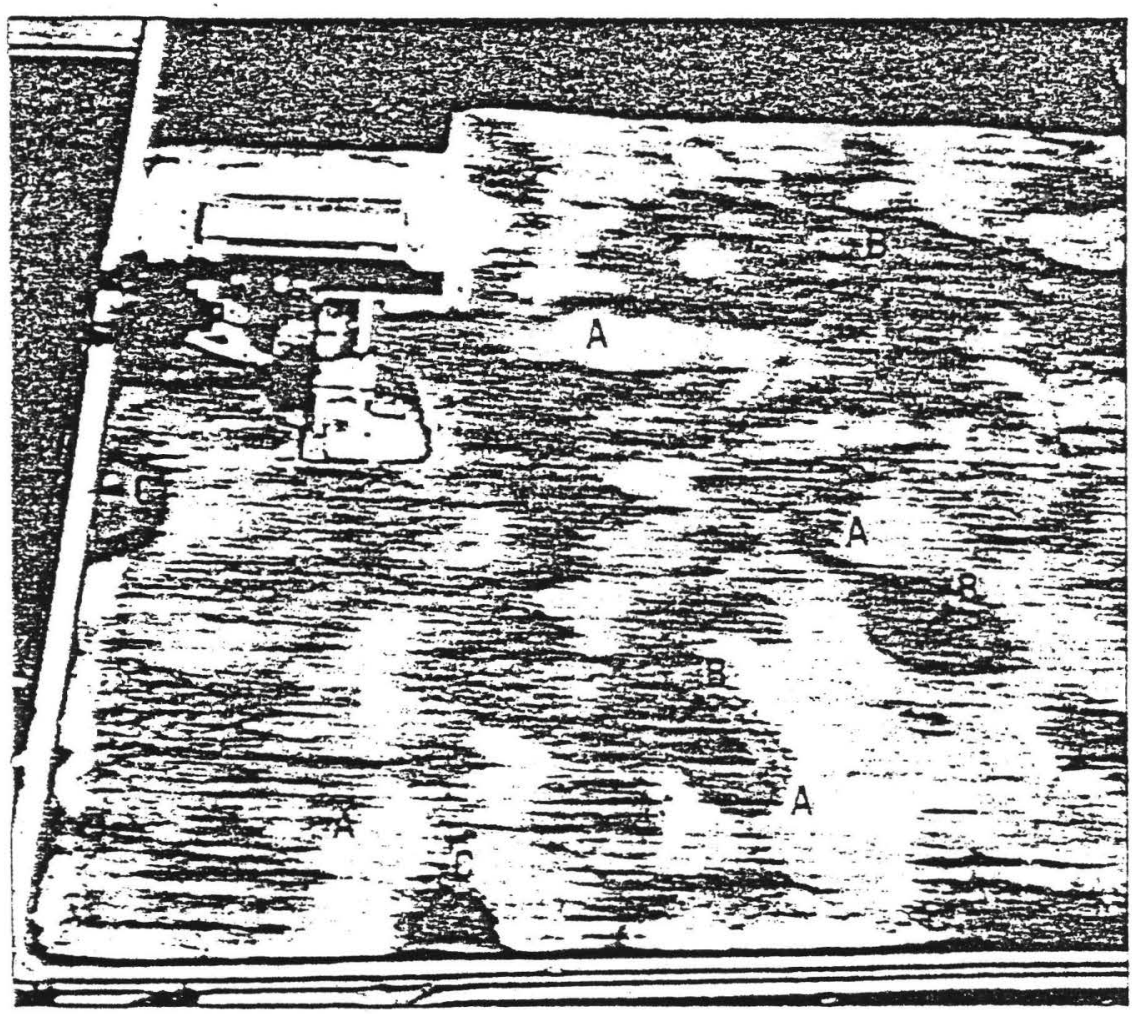


ferred to as "false-color tilm" also produces combinations of blue, green, and red in the tinal image; but the blue color results from exposure by froen light. the green color trom exposure by red light. and red color by exposure of the infrared sensitive laver by rellected infrared energy, noc heac. (Figure I illustrates the difference between nor. mal color and color infrared film.)

Healthy living plancs appear red on color infrared photographs because they have relacively high reflectance in the infrared region coupied with low retlectance in the green and red portions of the spectrum. Because of the unique renlectance characteristics of living vegetation. (high in the intrared and low in the visible), the film was originally used by the military to differentiate between real vegecation and painted camounlage material.

Color-intrared phocograohs are not at all difficult to use. A correct interprecation can usually be made by reiying on one's agricultural experience and familiarity with the area shown in the photographs. With a-little incerpreca. tion experience, it is possible to extract a great deal of information of direct use in agricultura! management.

The best way to gain this interpreta. tion experience is to walk the field, photograph in hand, observing the rela. tionship between ground conditions and their corresponding appearance on the color infrared phocograph. A great deal can be learned very rapidly in this manner.

Perhaps, this article will generace an incerest in considering this powerful tool which has the potential of making good managers even becter by helping supply additional valuable information to be used in the decision making process. $\boldsymbol{T}$

\section{Typical applications for infrared film}

Pre-planting: Decermine ield suriace conditions and cover (residue, standing water, etc.). Check condition of cerrac. ing, sod waterways, and other land sur. face features.

Emergence: Check germination success and stand establishment, looking for indications of environmental problems (insects, disease or weather), equipment failure (malfunctioning seeder) or perhaps human error (missed portions of the field). Check effectiveness of pre-emergence herbicides.

Mid-growing season: Check on stand growth and development through the growing season, looking for evidence of plant loss or damage due to adverse moisture conditions, misapplication of ag chemicals, insects, diseases, or other causes. Monitor effectiveness of herbicide creacmenc and drainage. Monitor forage availability in pastures. Monitor water distribution by irrigation systems. Pre-harvest: Check stand condition and acreage to be harvested, looking for lodging, heavy weed infestations or other potential problems for harvesting operations. Check for uniformity of ripening.

Post-harvest: Determine cotal area harvested. Check field cover in harvest. ed areas for weed and volunteer regrowth patterns.

As required: Document special situations such as tloods, cornado, hail, drought, or other types of damage. Check condition of shelterte!ts. $\boldsymbol{T}$

Figure 3-Color-intrared aerial photograph laken in mid-Seotember 1969, of the same fiald as shown in figure 1. The soil surtace is no longer visible, but striking patterns appear in the stand of corn. Although there were heavy rains eariy in the growing season, very little pain had fallen during the month preceding this photograph. Com in the well-drained portions of the field (A) has prematurely matured due to moisture stress. Notice the correspondence with the light-toned areas in figure 2. Corn in the less weil-drained areas ( 3 ) apparently had access to enough moisture to remain green and to continue normal development. Yield sampling determined average yieid in the stressed area to be 75 bushels pep acre. Portions of the stand with more available moisture (the poorty drained areas) yielded 1 to bushels per acre. (Figures 2 and 3 courtesy of Dr. Ralph Kiefer, University of Wisconsin, Madison.)

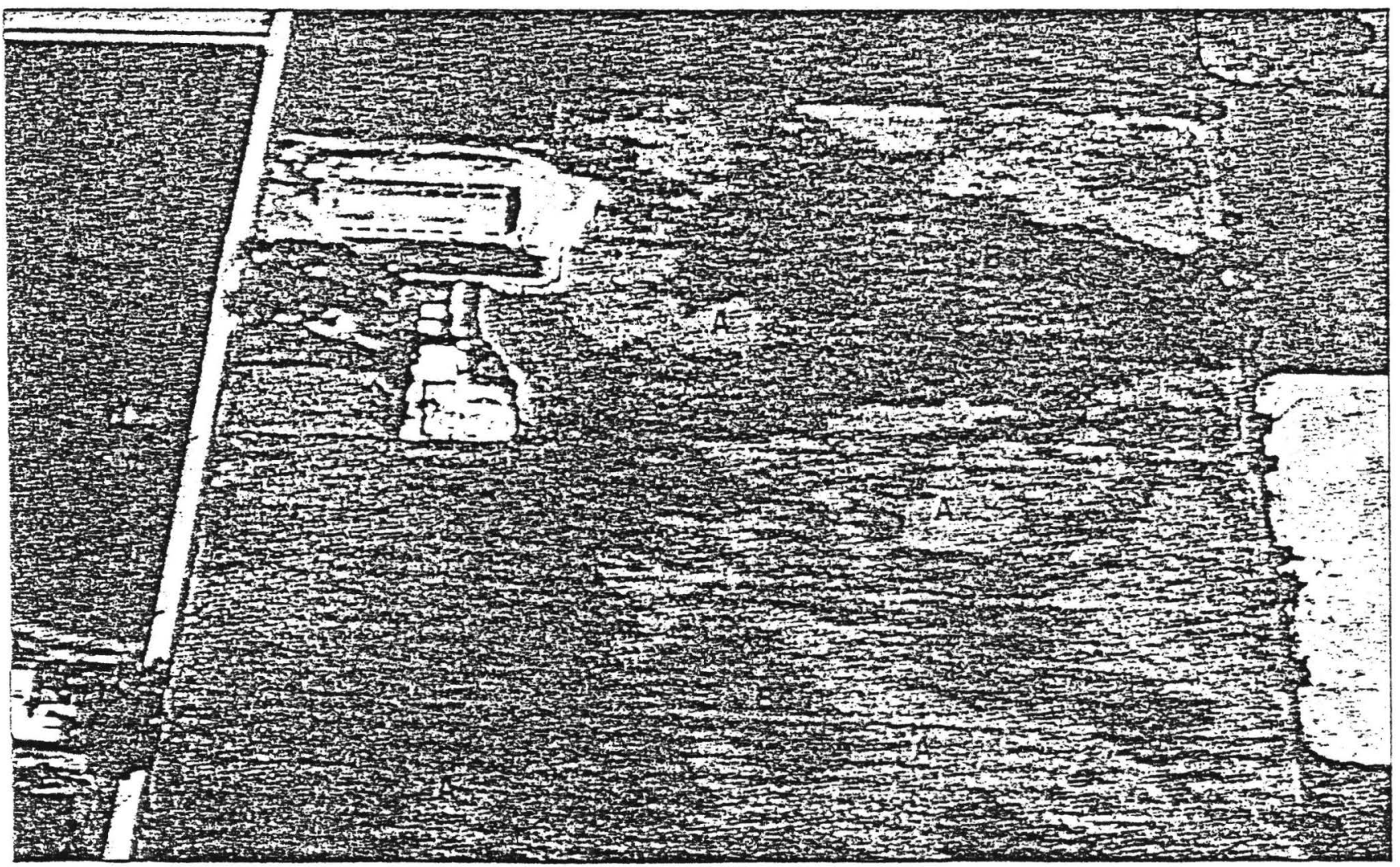




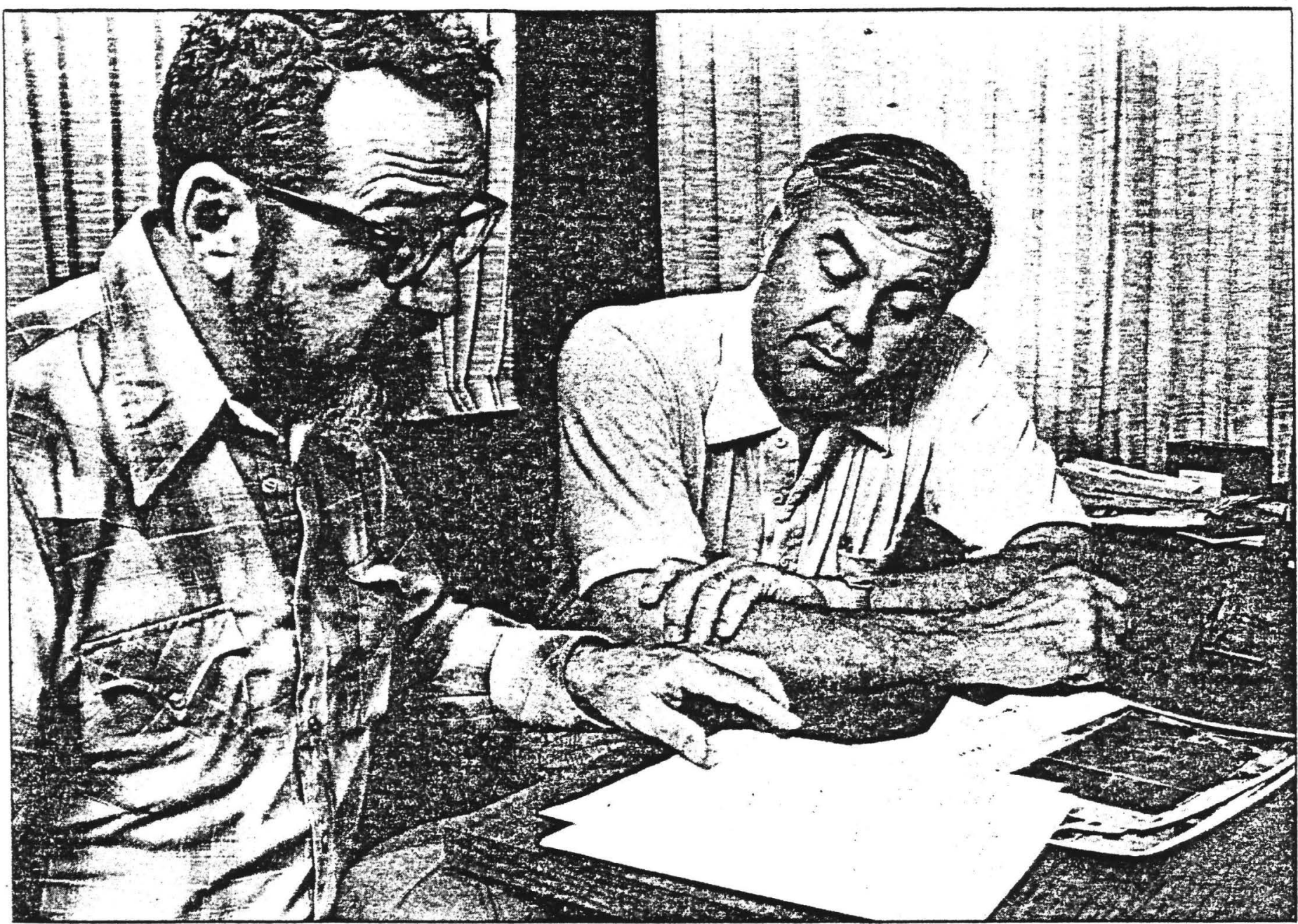

Using stides, color photographs, and graphs, Lynn Disbrow (left) briefs clients on a weekly basis. Here, he is pointing out some early-season growing problems to Otto Geisert, general manager of Baicom and Moe, Inc.
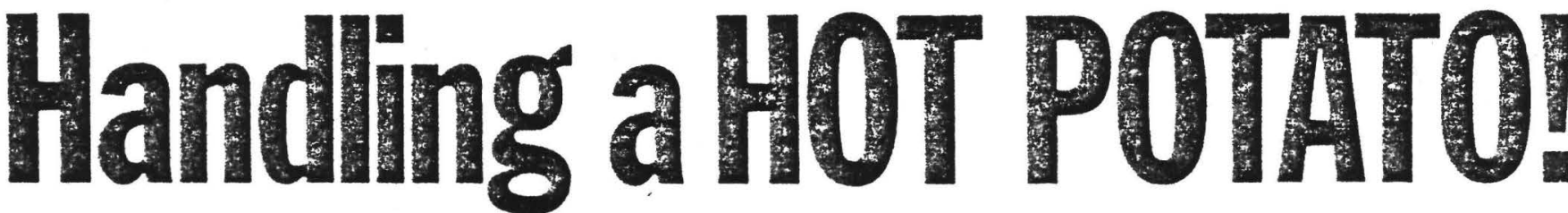

\section{How infrared aerial photography is helping to prevent blight in potato crops.}

In 1975 Oregon potato growers lost $\$ 3$ million when a potato blight wasn't spotted early and it had spread to thousands of acres in surrounding fields. Now infrared color aerial photography is being used by farmers in the Northwest to monitor whole field conditions and help prevent similar tragedies in the future.

"Modern scientific farming methods have made agriculture far less labor-intensive than it was in the past," reports Lynnford E. Disbrow, president of Infrared for Agriculture, Inc., of Pasco, Wash. "but the useful, constant, firsthand monitoring of crops by field hands has also been eliminated."

Disbrow, a retired Air Force lieutenant colonel, has been transfer ring expertise he developed flying photo missions in Viet Nam to the interpretation of aerial infrared color photograohs of eastern Washington and Oregon circle farms.

An arid semi-desert, the PascoKennewick-Richland "tri-cities" area depends heavily on irrigation for agriculture. Circle farming is the most practical from a labor standpoint. Circular fields uo to 125 acres are watered with rotating irrigation arms that can extend 1,300 feet from the centrai pivot. Giant machines are used to prepare the soil, plant seeds, and harvest.

Where a farmer once might have needed 40 men to work 640 acres, he can now easily take care of 3,500 acres with six," Disbrow explains. "But with people no longer walking through every field on a daily basis, it's become more difficult for the farmer to monitor whole field conditions accurately.'

Many eastern Washington and Oregon farms are made up of 100 or more circles, and have the services of a full-time agronomist. But even the most sophisticated random sample testing can miss important problems, Disbrow points out.

"Infrared color pictures can oinpoint problems that can't be spotted at all from ground level, no matter how closely a field is examined," he says. "Remote sensing from an airplane provides this data at an extremely low cost. For a few hundred dollars, a farmer can get weekly reports on a field in which 

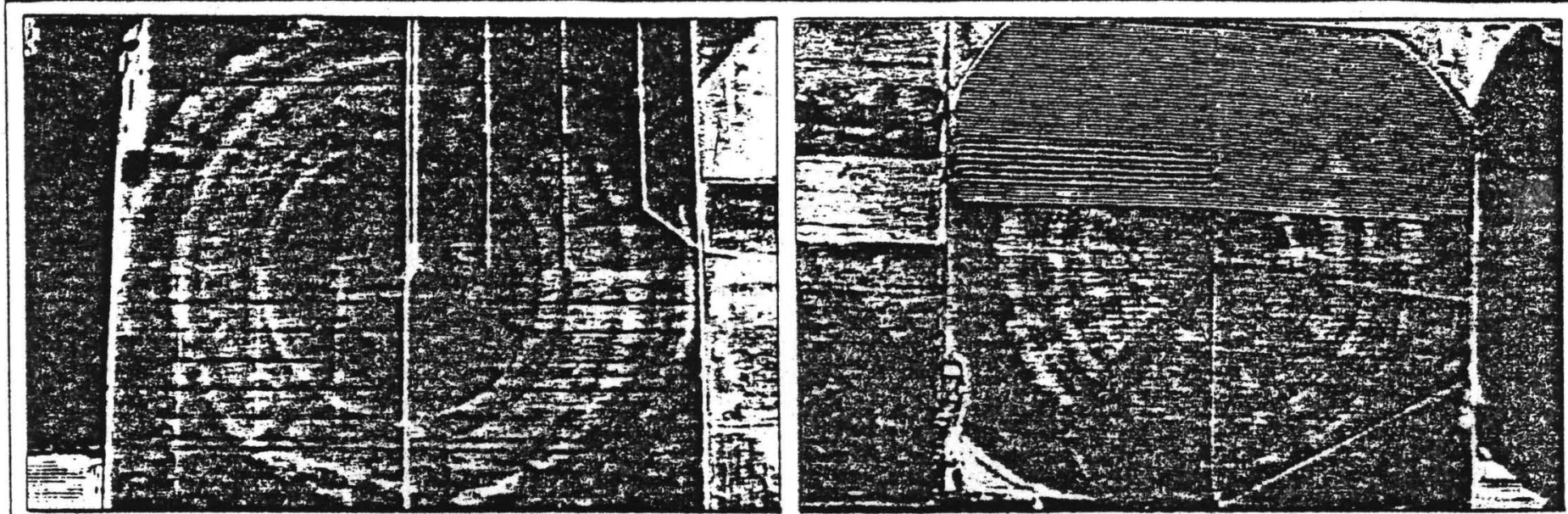

Poor watering is evident in this photograph of an asparagus crop. The center portion of the circle shows better irrigation

Often problems take several years to correct. Poor watering the previous season affected this alfalfa crop the following year, than the spotty, outer portions. The vertical, parallel lines in the even though the irrigation system had been repaired. Top half of upper right show old irrigation lines dug out when the pivot sys- the circle shows the rows of alfalfa prior to baling. tem was installed.

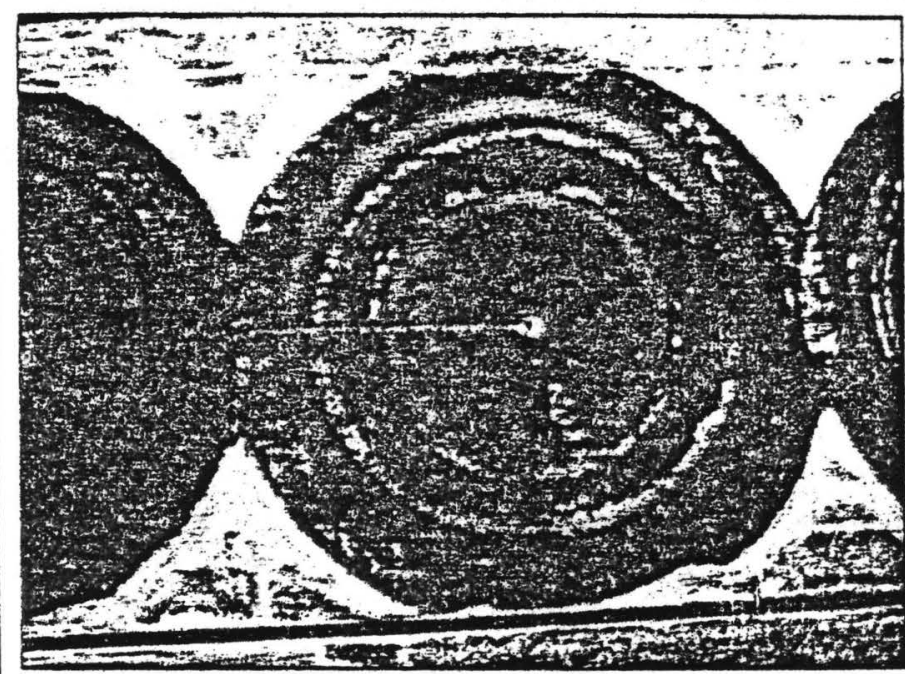

June wheat crop. Light brown areas are underwatered wheat. Light magenta areas show wheat that was overwatered, producing tall, weak stems that break. Photographed too late for corrective measures, this field yielded only one-quarter the normal crop.

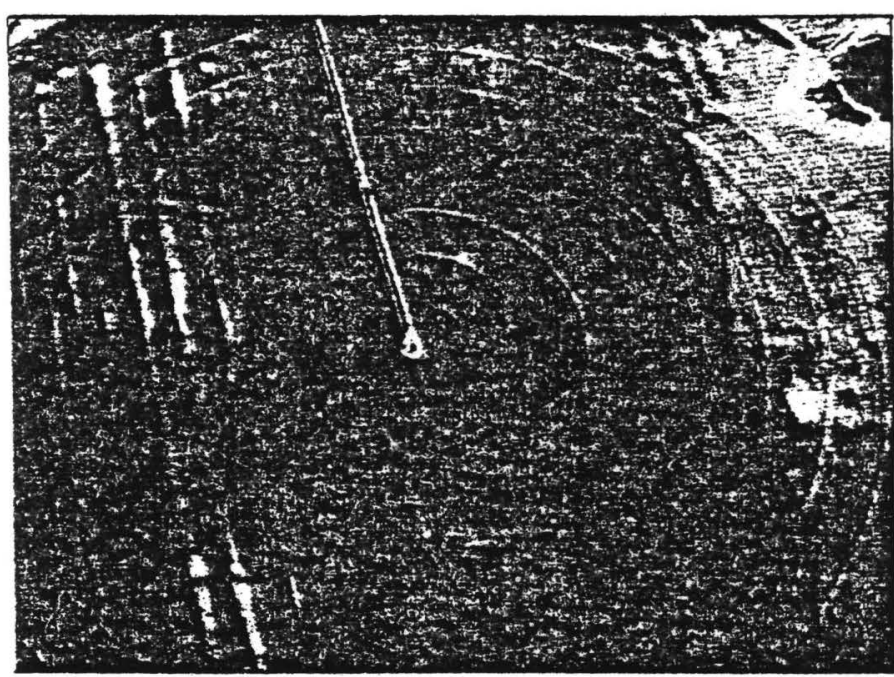

Wheat planted as a cover crop - potatoes were planted in the field two weeks later. Fertilizer skips show as light blue vertical lines at the left side. The farmer was able to correct this before the potatoes were planted. Light blue on right side shows sand blown onto field from an adjoining pond.
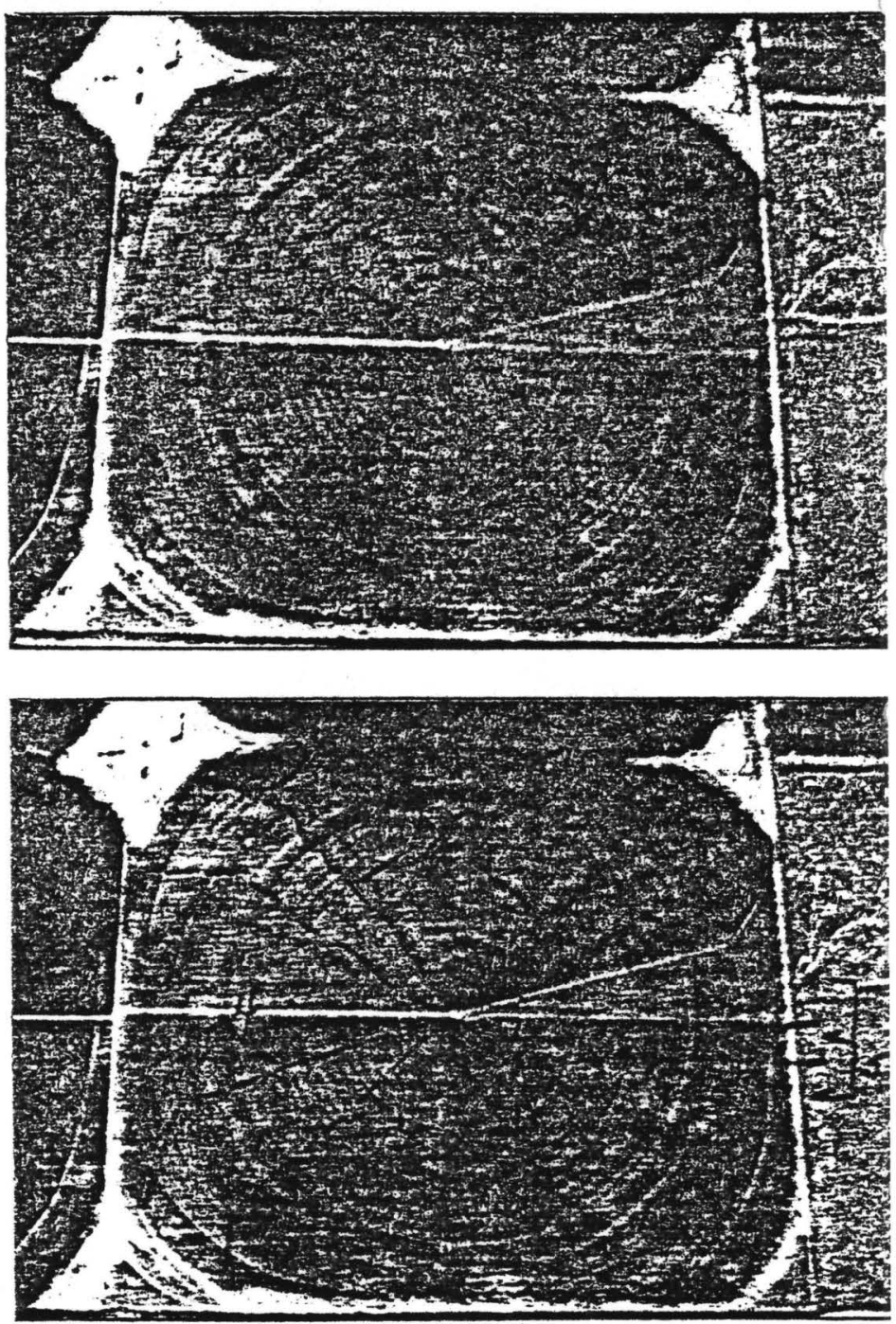

These pictures reveal a number of corn crop problems: 1 . Overwatering from three sprinkler heads. 2 and 3. Drier areas caused by failure of small switch at elbow of pivot not slowing irrigation arm while watering these areas of the field. 4. Swing arm did not shut off water, as designed, in this area, producing óverwatering. 5. Bands extending across field show experiment with different types of fertilizer. The darker, middle band did not produce the best resuits. Although early vegetation was better, the ears formed were smaller. 


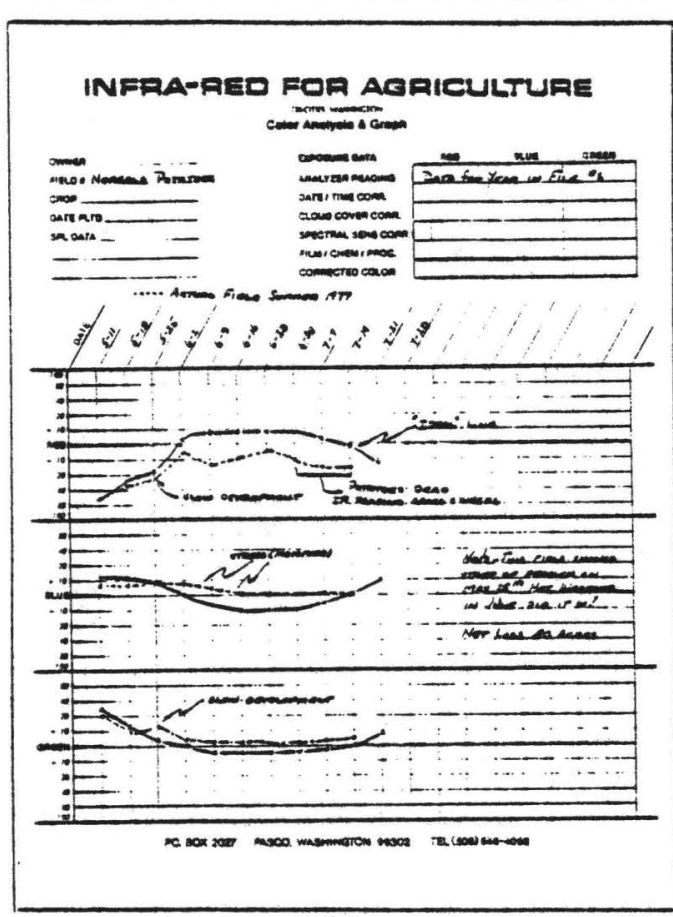

(Graph) Lynn Disbrow provides farmers with a graph showing spectral data over the growing season. The "ideal" line can be compared with actual re sults to spot trends.

he might have invested $\$ 100,000$ or more."

Kodak Ektachrome infrared film is used for the aerial photography. After processing, the film is copied onto Kodacolor II film, a color negative film. All negatives are kept on file for producing color prints. In addition, slides are also made for projection in customer briefings.

Disbrow has developed a sophisticated infrared interpretation technique that eliminates most of the human factor through the use of a color analyzer. But some interpretation of the film takes only a trained eye.

"There may be obvious dark and light bands in the aerial photograph," Disbrow says. "These most often indicate over- or underwatering caused by sprinkler head malfunction. It's possible to count sprinklers in the ohotograph and tell the farmer exactly which one isn't working properly."

Yet such diagnosis is often difficult or impossible on the ground. When viewed through binoculars, the afflicted sprinkler may appear to be functioning properly. But in fact, a seed or small stone may be cutting water delivery by 50 percent. The crops themselves may look healthy, but still produce a lower yield come harvest time.

"A single sprinkler located 1,000 feet from the pivot will be irrigating an area 20 feet wide and 6,000 feet

\section{DATA BASE: Factor}

"Collecting infrared aerial data of crop condition is relatively easy," says Lynnford E. Disbrow, president of Infrared for Agriculture, Inc., Pasco, Wash. "Interpreting the information takes a comprehensive data base that must be built up, as well as some means for eliminating variables and human error.'"

A data base built up over three seasons of overflights, ground truth checks, and consultation with plant disease experts forms the core of Disbrow's infrared aerial color photo interpretation procedure. A color analyzer - "zeroed" to eliminate film, processing, and sunlight variables - provides a sophisticated means of extracting information from the film that might not be apparent to the unaided eye.

Gathering the data is surprisingly simple, Disbrow says. He uses an automatic exposure $35 \mathrm{~mm}$ SLR camera fitted with $50 \mathrm{~mm}$ and $35 \mathrm{~mm}$ lenses. Both are used with Kodak Wratten gelatin filters \#12 deep yellow.

Auto exposure and motor-driven film transport make the actual picturetaking a point-and-shoot operation. Disbrow has equipped his camera with a databack that imprints date, frame number, and roll number in one corner of the picture area.

"This heips match frames later," he explains. "As we fly over fields, I record frame numbers of each exposure on a map I keep next to me.'

Most overflights are at 6,000 feet, with Disbrow shooting vertical perspective pictures through a removable panet in the floor of the plane.

Kodak Ektachrome infrared film, stored in a freezer before use, is carried in an insulated container between exposure and processing. From 60 to 200 fields may be photographed in a single flight.

After processing, the film is copied onto Kodacolor II film, a color negative film. All negatives are kept on file for producing color prints. In addition, slides can also be made for projection in customer briefings.

The key to consistent, accurate interpretation of aerial infrared color pictures, according to Disbrow, is the elimination of variables, so that a change on the film can be correlated to a change in field condition.

He exposes a control frame at the end of each roll, using a standardized target and light source. The control frame is then examined under a color analyzer which can then be "zeroed" to the control target's known values. This step eliminates changes caused by variations in the film or processing.

Cloud cover also alters spectral characteristics of the exposures to a certain extent. Disbrow has worked out a table that provides a factor for any given percentage of cloud cover.

"When these variables have been accounted for," he says, "the magenta, yellow and cyan layers of the film are examined separately, and the figures the color analyzer produces entered on a graph. The graph's lines show the amount of light reffected by a given field by each film layer over the full 15 critical weeks of the growing season." Laid over these plottings are "ideal" target curves developed by Disbrow by examining many thousands of frames of material of similar crops at similar times of the year.

"A small, but steady decrease in the blue spectrum could signal a slight increase in the yellow reflected by the field," Disbrow says. "This change might not be discernible to the eye at ground level, and may not even be apparent in the infrared color picture. However, the analyzer will read these small changes."

He continues, "By comparing the curves of a field's graph with known field conditions in his data base, it's often possible to spot overwatering, underwatering, improper fertilization, or the beginnings of a plant disease.

"Too much nitrogen fertilizer causes leaves to turn a dark green," he says, "which shows up on film as an increase in blue - with no change in the red. Moisture stress, or disease can also cause a darker leaf, but the increase in blue is accompanied by a decrease in red as well.

"The analyzer makes it possible to detect very small changes accurately," he notes.

Disbrow has a patent pending on his procedure, which he feels could be widely used by farmers all over the country. 

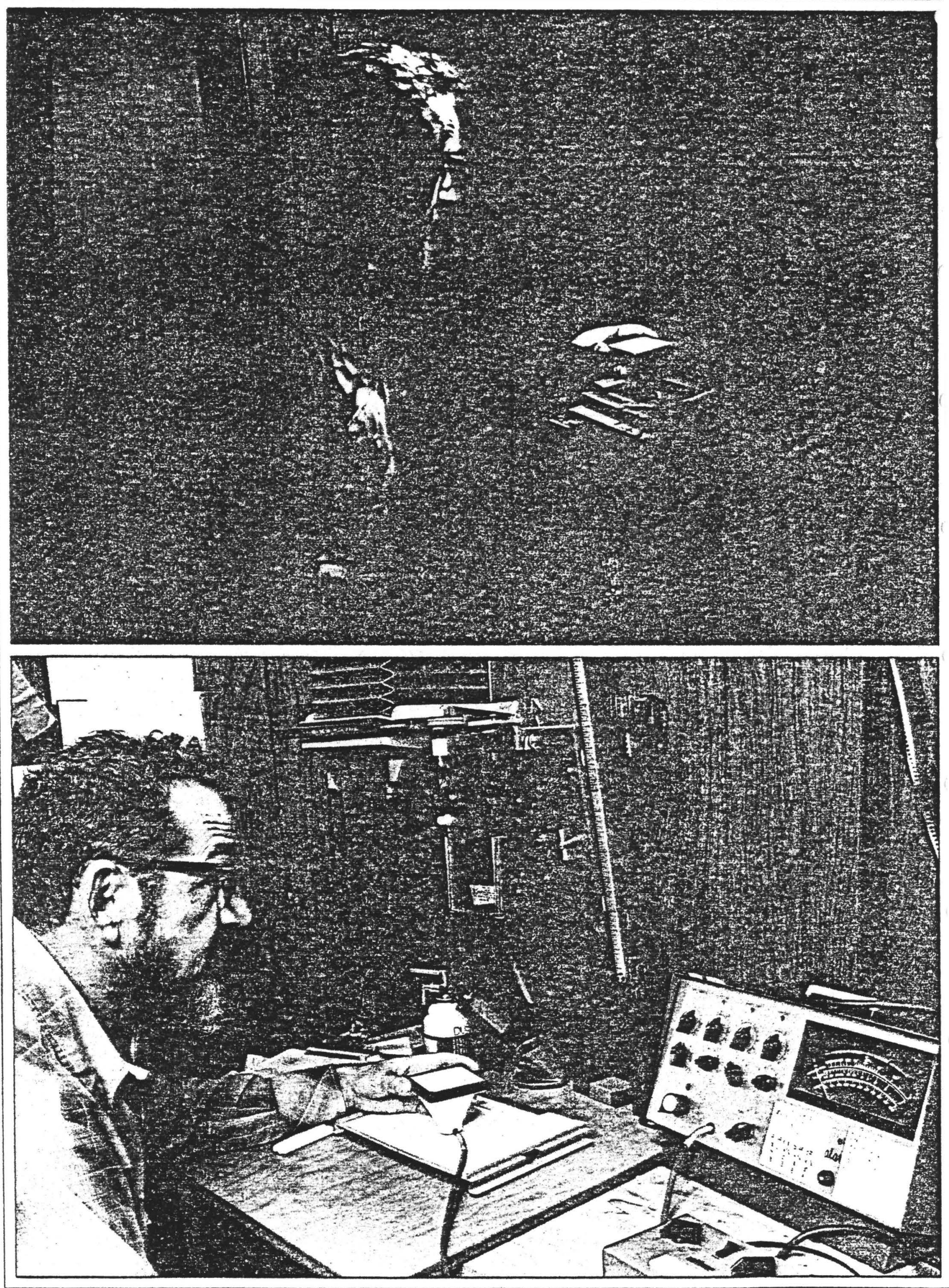


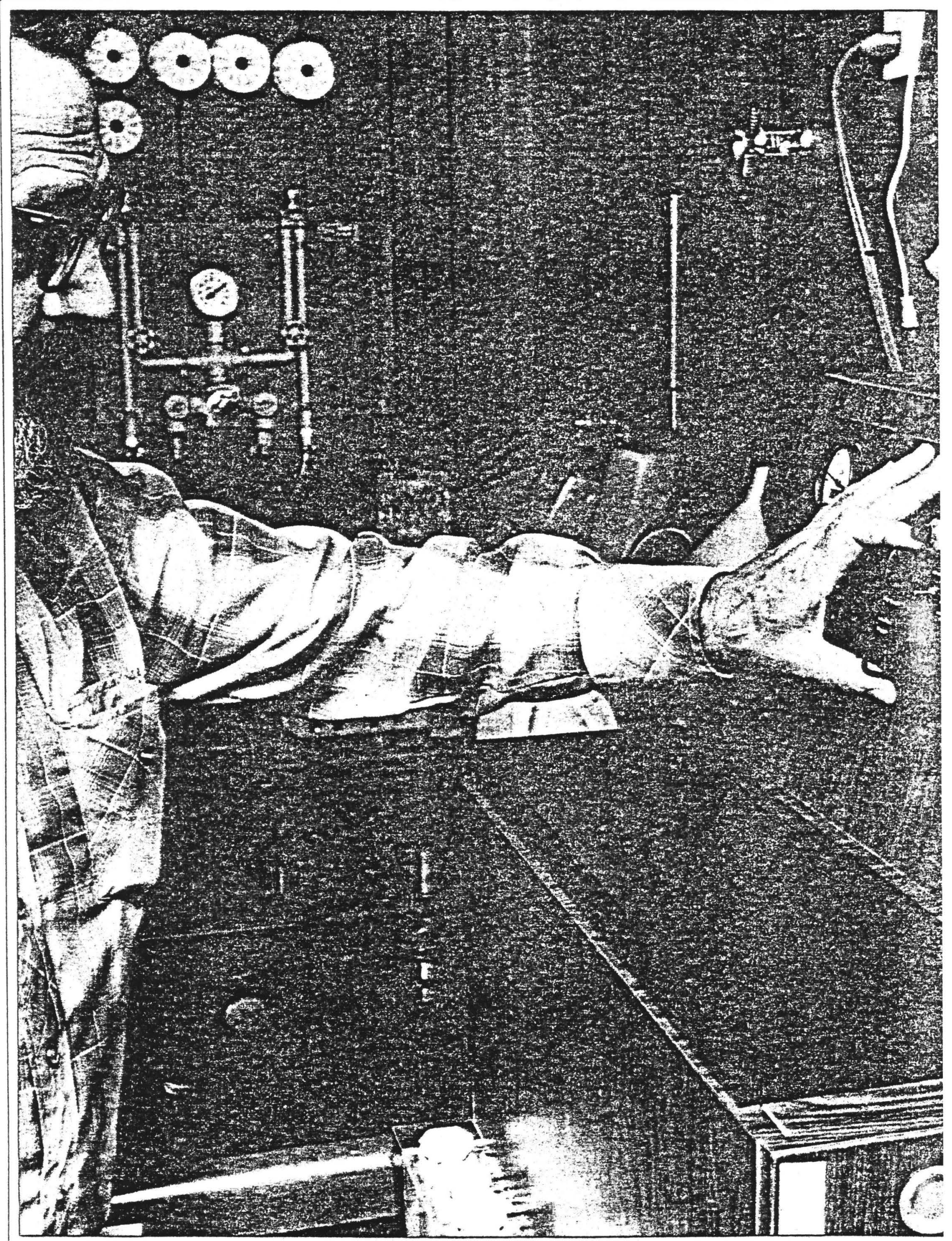

Process E-4 chemicais are used to process the infrared film. 
Eight-second exposure under darkroom conditions.

long. That's three acres of crop, valued at possibly $\$ 3,600$, that could be lost because of a bad $\$ 20$ sprinkler," Disbrow says.

He often finds that the first overflight of the season will locate potential problems that save the farmer enough money to pay for all that season's photography and interpretation.

One farmer wasn't aware that a nitrogen fertilizer pump had broken down in one field. The dealer who supplied fertilizer noticed that the tank never seemed to require topping up - but assumed the farmer had shut the pump off. Not until Disbrow spotted the Blue shift on the IR aerial photograph was the pump problem diagnosed.
Other symotoms are often captured by the aerial photographs, but require more sophisticated interpretive techniques. Disbrow has developed a system using a color analyzer to detect small changes in the color quality of the light reflected by crops as the season progresses. These changes are compared with "ideal" charts he has prepared to measure field progress, or diagnose problems.

'The key to successfully evaluating field condition is to build up a mass of data to use as a base," Disbrow says. "I worked with farmers, county extension agents, and agricultural disease experts to determine how what I was seeing in my aerial photographs correlated with what was happening on the ground. It takes a lot of wading around in mud at ground level, soil tests, and tissue tests to do that."

He has found, for example, that too much nitrogen - as well as several diseases - cause plant foliage to turn a darker green. But each condition produces a distinctive change in the other colors recorded by the infrared film which Disbrow can spot in time for the proper corrective action to be taken.

"That's the key point I always impress on the farmers I work with," Disbrow says. "All the infrared photography in the world won't make a better crop. My customers have to take what l've found, and use it to improve their yields."

Disbrow checks a removable plate before taking his airplane up.

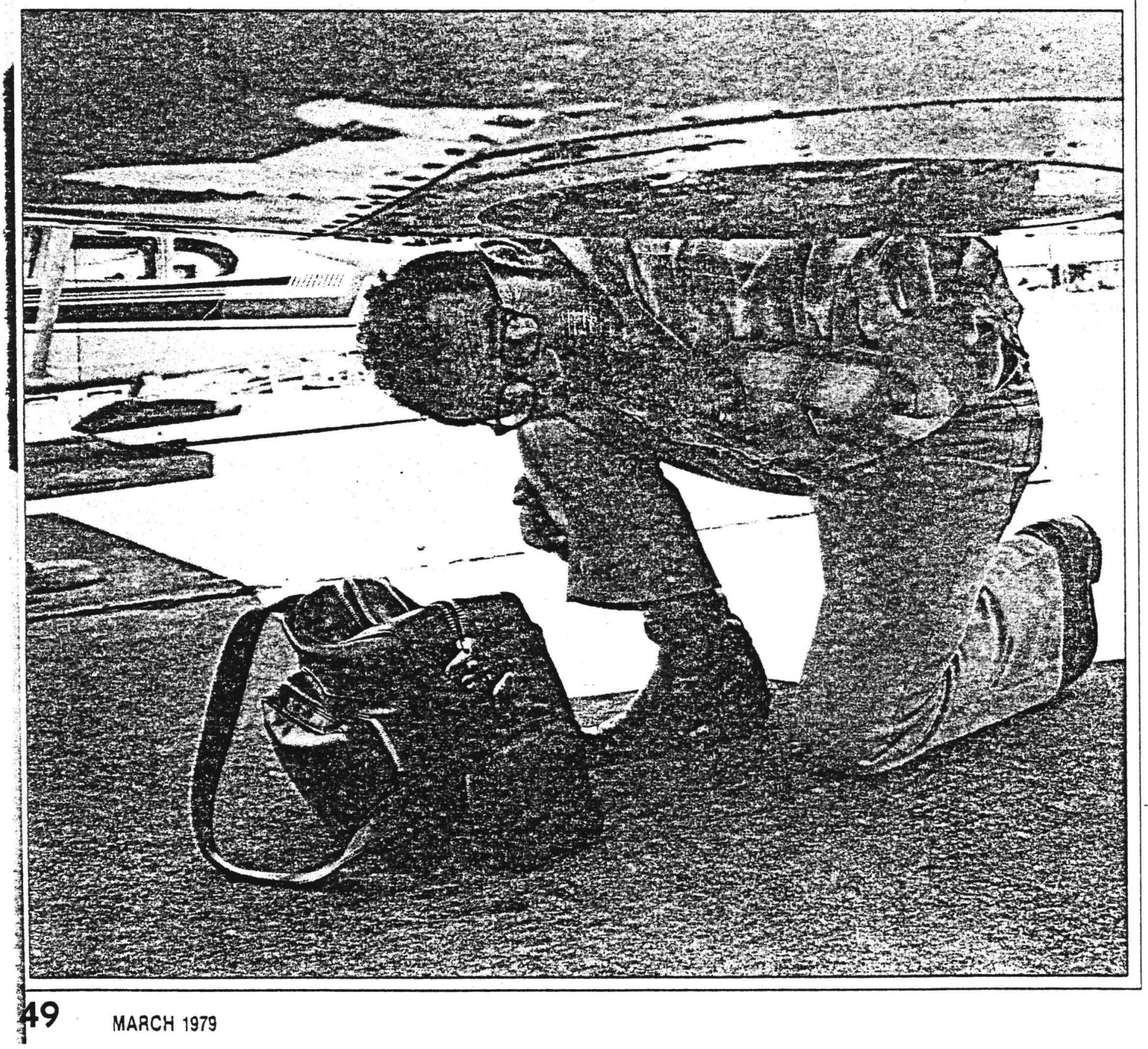



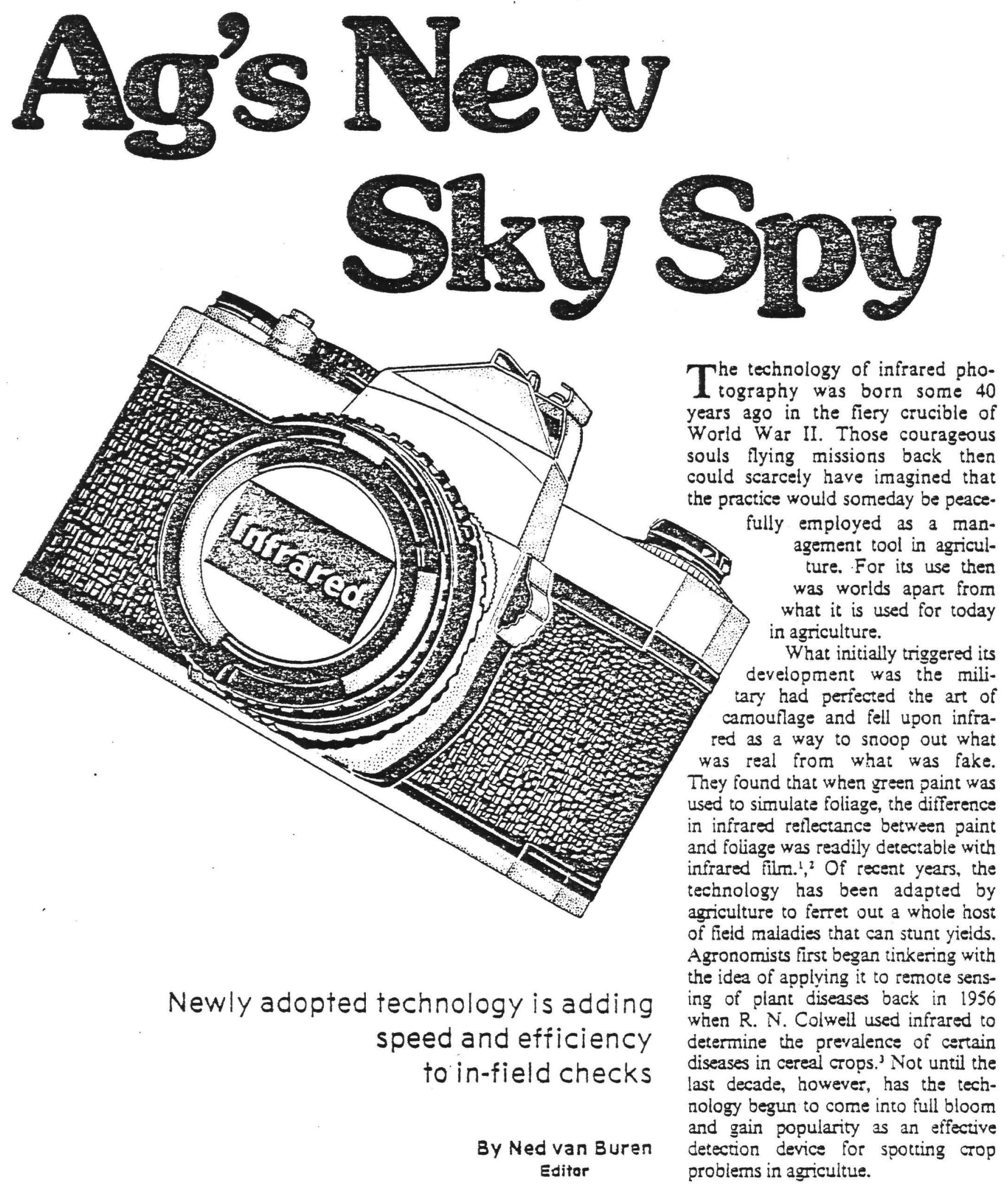

How it Works

There often has been the misconception that color inirared film records the temperature of objects in the scene. What actually occurs is the film reads beyond the normal visible portion of the light spectrum into the infrared region, owing to its emulsion's high sensitivity. "Healthy living plants thus appear red on color 


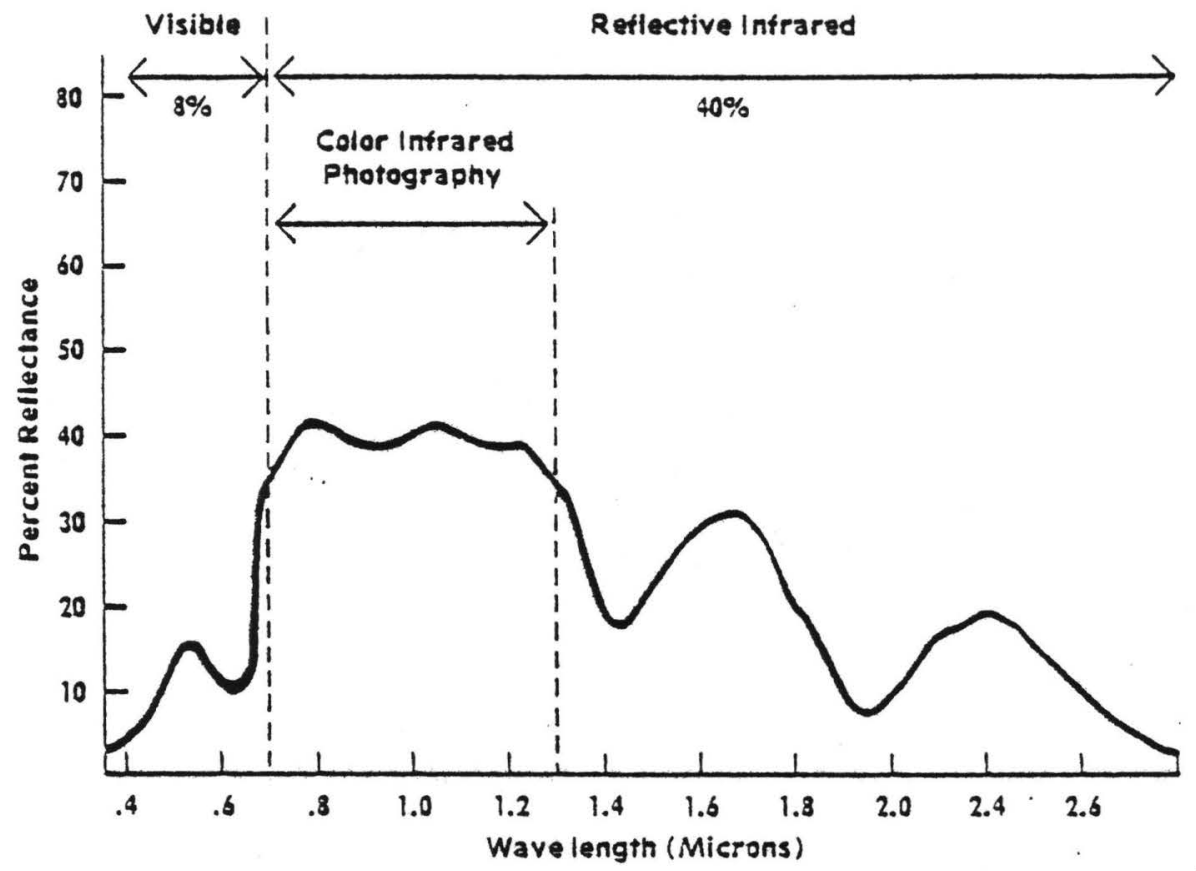

Figure 1. Visible/invisible light spectrum as it relates to intrared.

\section{Infrared ...Continued}

infrared photographs because they have relatively high reflectance in the infrared region, coupled with low reflectance in the green and red light portions of the light spectrum.

Figure 1 shows the unique qualities of the invisible or infrared spectrum and explains why you can tell more about the condition of a plant. The visible spectrum, which can be seen by the naked eye or natural color photography, records about only 8 percent of the total light reflected from a green leaf. The infrared spectrum, on the other hand, views slightly over 40 percent.' This means that the slightest changes in crop reflectance will be enhanced and have greater chance of showing up on infrared with its wider range of visibility (Figure 2).
Unhealthy plants may take a brown cast on infrared or show up light pink to an almost white bluish cast-distinctly not healthy red and highly discernible on the photograph. Water holes or poorly drained areas with sitting water appear as dark areas or spots and weeds appear in a distinct purplish color. The best way to gain interpretative experience, however, is to walk the field, photograph in hand, observing the relationship between ground conditions and their corresponding appearance on the color infrared photograph.

\section{Why it Pays}

The spiraling infiation of the last decade makes it more imperative than ever that farm operations become increasingly efficient. With sagging commodity markets and cost pinches, agriculturists must find tools with which to fight back and

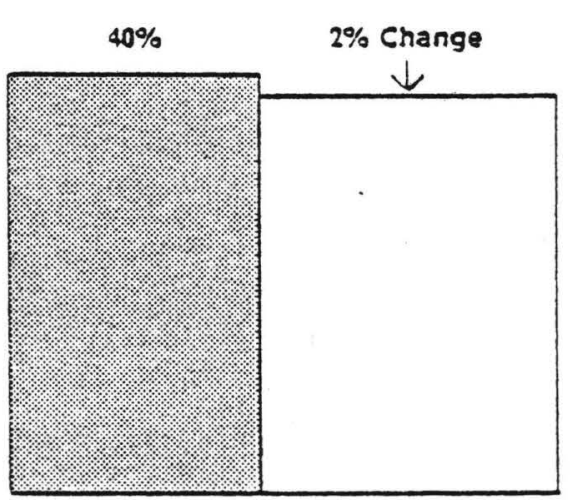

Infrared Reflection
Visible Reflection

$2 \%$ Crange

$\downarrow$

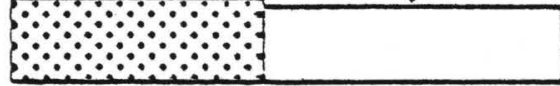

Reflective Range Comparison the practice of infrared photography is proving one of them. It dovetails perfectly with diagnostic or in-field check programs which are gaining. more and more prevalence.

Where field scouting traditionally has been a time-consuming task of walking vast areas, and usually only partially at that, we are now witnessing a sharp change of complexion that is adding new dimensions both in terms of time and amount or thoroughness of coverage. Infrared has introduced a detection system that can sweep in a field or series of fields in one shoc, vastly cutting the scouting time. By studying the aerial photos, field scouts can now pinpoint problem areas in fields and walk right to them, obviating the timeconsuming ground hunts of the past. In a comparison with its former method of ground surveying, one division of the USDA estimates that aerial infrared surveillance has reduced its scouting costs by 63 percent.' A Nebraska dealer notes he has been able to photograph his customers' fields for as low as 20 cents an acre. Still another comparison study by the USDA in Weslaco, Texas, shows that it reduced scouting costs 43 percent when it switched to infrared photography to survey citrus groves.'

Impressive as these figures may be, the practice of infrared photography has many other attending advantages. Because it is more accurate and thorough it has become highly supportive of good manage. ment practices. It has broad capabilities for detecting crop and lield problems: It can pinpoint plant areas in fields which are beginning to show signs of stress before stress signs can be seen with the naked eye. ${ }^{3}$ It can chart parched crop areas and tell growers when they're in need of irrigation. It can detect weeds, changes in soil type, low and high areas, fertilizer deficiencies and the presence and spread of diseases. ${ }^{7}$ It can increase farming efficiency in terms of fuel/energy, seed, fertilizer, pesticide and water requirements. ${ }^{\circ}$ And finally, it can spot poor water and fertilizer patterns and equipment failure.'

Thus, speed, reduced costs, dexterity and diversity have combined to make infrared the potent tool it is and are responsible for its rapidly accelerating acceptance in the ag community today. 


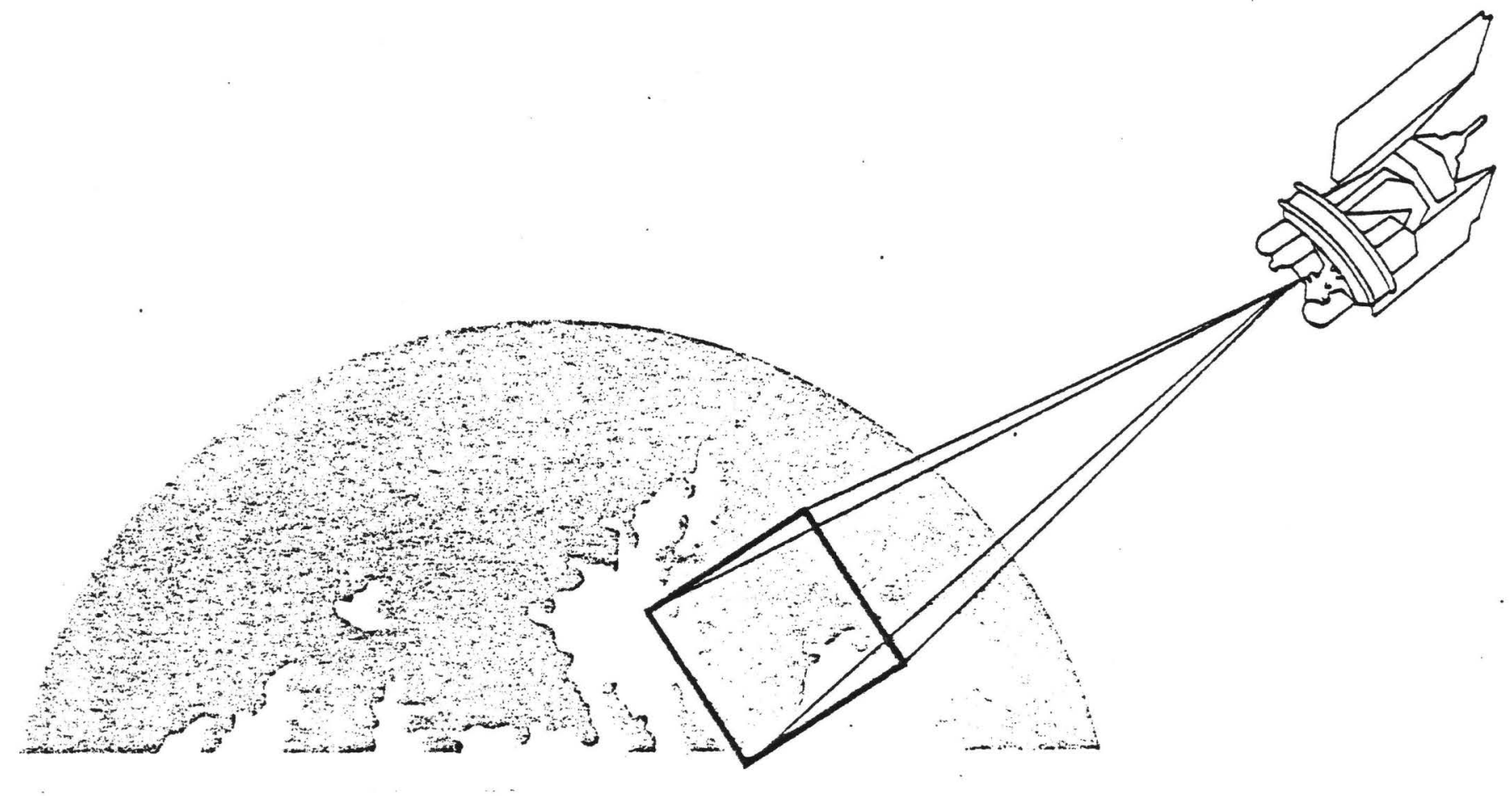

Equipment

The equipment available for infrared photos runs the gamutfrom the inexpensive to the very expensive. It can range from the small dealer who uses a $35 \mathrm{~mm}$ camera to a multispectral scanner that rides aboard a Landsat satellite. All are performing the same task but on vastly different scales.

For the fluid fertilizer dealer or members of the scholastic community that must operate on limited budgets, a typical high-quality amateur $35 \mathrm{~mm}$ camera will do the job. A representative survey conducted by SOLUTIONS has shown that the camera equipment used can range from a lower-priced Minolta SRT 101 to the higher-priced professional-caliber Hasselblad $70 \mathrm{~mm}$. Many of those surveyed indicate they use only those camera modeis available with a motor drive for the purpose of quick film advance. One of the most frequently mentioned or appearing infrared films is Kodak 8443. Other accessories required are proper filters and shutter trip cords.

The big hurdle for the small operator is to find a way to economically make the overflights, properly mount his equipment and still make it pay. The options are two: ouy his own aircraft (at considerable expense) or rent. And the rental rate for aircraft can vary considerably. Among those surveyed, it runs from $\$ 26 /$ hour to $\$ 100 /$ hour, depending upon type of aircraft and locale.

On a larger scale, such organiza. tions as NASA are using 11-channel spectral analyzers aboard aircraft they fly at 1,500 feet." The reflectance intensity data from the sensors of the multispectral analyzer are recorded on a FM magnetic tape recorder and read directly into a multispectral image analyzer which digitizes the data. The process has been used successfully in detecting disease stress in trees.

The ultimate in equipment can be found riding aboard a satellite such as Landsat that is in a sun-synchronous orbit some 500 miles above the earth, allowing the earth to pass below it in the same level of light every day.: In Landsat, a multispectral scanner scans back and forth along lines perpendicular to the satellite's path. At any instant, it captures reflective light from an area one acre in diameter, called "instantaneous field-of-view" (IFOV). Over $7 \frac{1}{2}$ million IFOVs make up each Landsat scerie of about 13,000 square miles. Landsat has been used to identify soil characteristics, the extent and severity of stresses related to plant disease and drought, as well as to predict crop yields. Some agronomists involved in the program even predict the day a dealer or grower will be aole to tap into a computer terminal and pinpoint where he is having plant itress or other problems in his fields-all courtesy of satellite sensors. ${ }^{13}$

There can be little doubt that such equipment options and/or services available to members of the ag community, as those just described, will continue to multiply as the future unfolds.

\section{Surveillance}

Timing and altitude are two primary considerations in airctaft surveillance for which no set rules have been established.

Time of day has varied from llight increments of between 9 and 10 in the morning and 3 and 5 in the afternoon to single stretches of between 10 in the morning to 4 in the afternoon. One group of researchers opts to fly two hours either side of maximum sun angle (noon) because it feels it minimizes the effects of shadows that tend to interfere with reflectance characteristics of surrounding vegetation. ${ }^{4}$ 
Observation Periods

Pre-planting

Emergence

Mid-Growing Season

Pre-Harvest

Post-Harvest

As Required

\section{Typical Applications}

Determine field surface conditions and cover (residue, standing water, etc.). Check condi. tion of perracing, sod waterways, and other land surface feafures.

Check germination suecess and stand establishment, looking for indications of environmental problems (insects, disease or weather), equipment failure (malfunction. ing seeder) or perhaps human error (missed portions of the field). Check effectiveness of pre-emergent herbicides.

Check on stand growth and development through the growing season, looking for evidence of plant loss or damage due to adverse moisture conditions, misapolication of ag chemicals, insects, diseases, or other causes. Monitor effectiveness of herbicide preatment and drainage. Monitor forage availability in pastures. Monitor water dis. pribution by irrigation systems.

Check stand condition and acreage to be harvested, looking for lodging, heavy weed infestations or other potential problems for harvesting operations. Check for uniformity of ripening.

Determine total area harvested. Check field cover in harvested areas for weed and volunteer regrowth patterns.

Document special situations such as floods, pornado, hail, drought, or other types of damage. Check condition of shelterbelts.
Comments

Aerial photograohs paken during this observation period are good for obtaining soil pattern information because the field surface is not obseured by vegeta. tion. Soil type and moisture content have a strong intiluence on apparent pattern.

These photos are particularly valuable for making peplanting decisions in fields of Fall-sown small grains. Can usually be taken and interpreted in time to take corrective action such as reapplication of herbicide in problem areas.

Problems noted during the growing season such as persistent wet spots or soil blowouts can be scheduled for cor. rection. Spot applications of agricultural chemicals can be made. Uneven aerial apolications usually apparent. Apparent crop damage cannot always be unambiguously related to exact cause. Many stress conditions appear similar from aerial perspective and require field check for precise diagnosis.

If severe limitations to harvesting are found, then photos become especially valuable in planning salvage harvest operation. Suspected vapiations in yield within the field can be identified for ground checking.

Acreage not harvested can be deter. mined for later harvest or possible insurance claim documentation.

Photo documentation extremely valuable in litigation and insurance cases. Shelterbelt imorovements can be planned as required.
Flight altitude has shown equal variance. Depending upon the objectives of each mission, overflights have been made as low as 500 feet to highs of 10,000 feet. It also has been noted that altitude-particularly at lower distances-will have a yery definite effect upon shutter speed of the camera.:

Attitude of the camera is another consideration and it is generally agreed that vertical angles $\left(90^{\circ}\right.$ to the ground) offer the most accurate perspectives of the fields being studied. One report indicates that photographs taken at oblique angles show a loss of dimensional perspec. tive with increasing altitude. " Details were present on these high-altitude obliques but were not as apparent as on low-altitude obliques.

While seasonal effects governing photographic timing show variance by crop and geographic region of the country, there is general agreement on pre-season, post-emergence, midseason, pre-harvest and post-harvest schedules to follow in making infrared checks on fieids. Table 1 offers a representative schedule.

\section{Precautions}

According to the experiences of one soil chemist from Texas, there are certain precautions or procedures that should be observed in assuring optimum results when taking infrared photographs. ${ }^{15}$

- Transport film to field in ice chest

- Allow film to thaw two hours before use

- Do not use automatic setting on camera

- Over-expose one shot and underexpose one shot for best results

- Know your pilot

- Use soil test and tissue analysis to identify probiems

- Remember: a red color in a crop does not necessarily mean a profit; it could be delayed maturity or younger tissues. 


\section{Future}

The advancing technology of aerial infrared photography as reviewed in this article is literally putting the agricultural world under a microscope. As a diagnostic tool it might be compared to and make as much sense as the X-ray used by the physician.

How well the future bodes for this technology may be best expressed by Dr. C. H. Blazquez of the Institute of Food and Agricultural Services and assigned to the Kennedy Space Center in Florida. "The biggest thing we have to do is show growers it will work," he says. "It's one thing to tell them, but we know they'll have to see it working to believe in it."

\section{References Cited}

1. Hart, W. G. and V. I. Myers; "Intrared Aerial Color Photography for Detection of Populations of Brown Sott Scale in Citrus Groves, "Journal of Economic Entomology, pp. 617.624, June 1968.

2. Seevers, Paul M. and Velma Wiegand; "Continuation of Evaluation of Color Infrared Photography for Monitoring Cropping Problems," University of Nebraska report, March 1979.

3. Blazquez, C. H.; "Remote Sensing of Foliar Diseases of Vegetable Croos With Intrared Color Photography," Florida State Horticultural Society Proceedings, November 1972.

4. Anderson, William $\mathrm{H}$.; "Infrared film for aerial photography," Irrigation Age, February 1979.

5. Omax Biosensing, Omaha NE; "Aerial Biosensing Increases Your Management Eificiency," 1978.

6. Hart W. G., S. J. Ingle, M. F. Davis and C. Mangum; "Aerial Photography with Infrared Color Film as a Method of Surveying for Citrus Blackfly," Journal of Economic Entomology, February 1973.
7. Har. W. G.; "Intrared Aerial Color Photography for Detection of Citrus Pests," Fourteenth Southern Forest Insect Work Conference, 1969.

8. "Space Age System for Fighting Diseases." Progressive Farmer, April 1977.

9. Hannon, Ron; "Remote Sensing." Florida Grower and Rancher, 1973.

10. Harris/Omax Infrared Crop Man. agement Data Sheet, 1979.

11. Edwards, George J., Tom Davis and Carlos H. Blazquez; "Image Analysis of Multispectral Sensing Data of Young Tree Decline in Citrus," Proc. Fia. State Hort. Soc. 89:26-28, 1976.

12. "Remote Sensing of Agriculture, Earth Resources and Man's Environment," Purdue University, 1977.

13. Keckler, D. A.; "Resource Macping Satellites," The Grower, December 1978.

14. Green, L. R., J. K. Olson, W. G. Hart and M. R. Davis; "Aerial Photographic Detection of Imported Fire Ant Mounds," Photogrammetric Engineering and Remote Sensing, po. 1051-1057, August 1977.

15. Pennington, Dale; "Outline for Intrared Slides," Texas Agricultural Extension Service, 1979. 


\section{Infrared Proving}

B assett, Nebraska, is a diminutive community of 1,000 that sits in the middle of irrigation country. A mere blink of the eye when overfly. ing these north central flatlands of Nebraska will sweep in millions of dollars worth of center pivots that dot the landscape below. It is an awesome sight and so are the investments. Protect. ing these investments is one of the primary functions of luid fertilizer dealers serving farmers in this area.

Fulfilling this role in grand style is one of the area's more dominant and aggressive dealers known as Coash, Inc. Founded by Harold Coash in 1954 and headquartered near the center of Bas. sett, the company is employing the practice of infrared photog. raphy to assist in diagnostic work on field crops. "It's an ideal tool that lends itself well to our size of operation," explains Don Coash, son of the company's founder, who has spearheaded the development of this technology since he graduated from the University of Nebras$k a$ in 1974. "We operate out of satellite plants in Bartlett and Albion also, so we're talking about 100,000 acres we've got to oversee. The infrared gives us the speed and vast coverage we need to efficiently and effectiveiy serve this amount of acreage."

The burgeoning company sells almost exclusively to irrigation customers within a 30 -mile radius that slices the four-county area of Holt, Kenya Paha, Brown and Rock in north central Nebraska. Its products and services are diversified, taking in fertilizers, ag chemicals, propane, trucking and an equipment distributorshio in Lincoln, Nebras-

ka. Coash also owns and operates a

\section{Dealer} Assist

fully complemented lleet of highflotation applicators, delivery trucks and semi rigs.

\section{Immediate Success}

Perusing magazine articles is what brought the youthful and venturesome Don Coash upon the idea of experimenting with infrared photography as a farming tool. "I read where they had been using it successfully on potatoes to detect early blight," Coash recalls. "They were detecting it early enough so they could use shemicals to control the blight. I was fresh out of college at the time."

Intrigued by the idea and that it might prove a valuable diagnostic tool, Coash wasted little time in beginning his search. "I started calling photography peoplejust plain ole photography stores," Coash explains. "I'd been working with a pocket camera up to this point and didn't even know what a $35 \mathrm{~mm}$ was. I also asked them about infrared film-what is was and how it was used."

About this time, Coash was attending

LEGEND: A. old field (needs soil sam. ple); B. sandy ridge (planter stressplanting too deep); C. Planter problems (planter sxipping); $D$. Water hole (low spot with settled water); E. Weeds (along pivot park position).

Nebraska dealer using practice to cut field scouting time during summer months an alumni meeting at the University of Nebraska and happened upon infrared again. "I discovered that the university had been doing some work when they showed us slides at this meeting," Coash relates. "So I checked into it further. They put me on to which filters to use, equipment to buy and the rest. The one change I knew I had to make was I'd have to work from the air-ihey were working from elevated ground platforms. When you're working with 130-acre center pivots you're going to have to fly over them." 


\section{Reverse Selling}

What has evolved at Coash, Inc. is a somewhat unique system for selling infrared by not reaily selling it at all. the core of our fertility program and pest management service. The infrared complements their efforts beautifully-serves as their intelligence reconnaissance, you might say.

"We can fit the-infrared into our

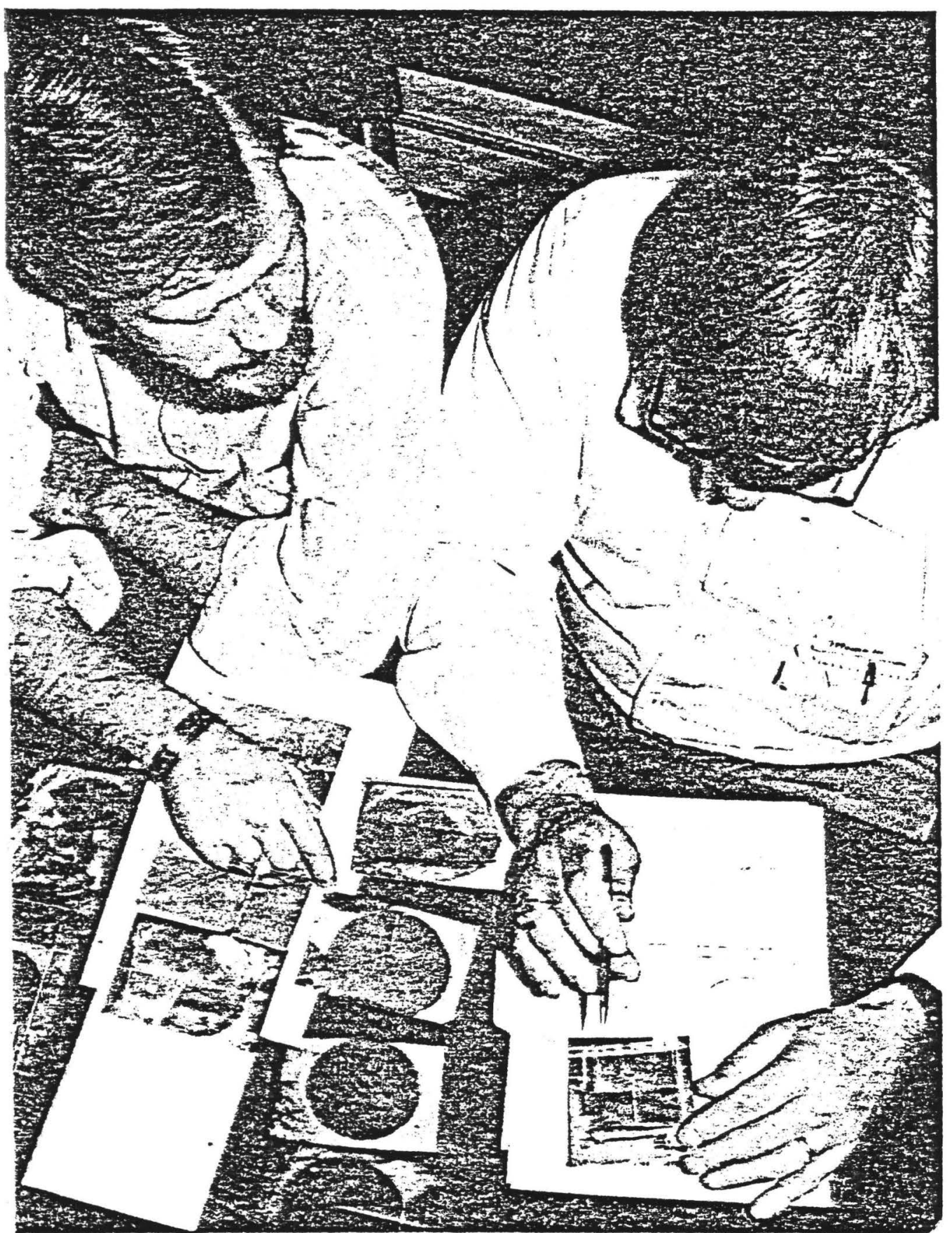

PROPER INTERPRETATION of intrared aerial photographs is ticklish art as well as key that spells difference between success or failure of the practice and pecom. mendations given. Sludying and diseyssing prints are Don Coash (left) and Dr. David Stamp, in charge of agronomy services.

It is included as a part of the cumpany's agronomic service to its customers. "We charge for our agronomic services, of course," explains Coash. "We have fuil-time agronomists and entomologists employed on our staff and they form agronomic programs without charging because, basically, it's not an expensive process. We've got our own piane, the film is inexpensive. We were initially convinced it was going to be an expensive service and that is one reason we explained there would be a charge for the service. But then we found it wasn't all that expensive. Basically, we're using it now as an in-house tool to assist olr scouts and we've found it has paid for itself-given us more business and helped us to do a better job in soil sampling and scouting."

According to Coash, turnaround time is one of the make-or-break considerations if infrared is to be made a selling tool. "We have our photos processed about 160 miles south of here in Grand Island," Coash says. "We usually have them back in two days and this is critical. This is especially true in July when that corn plant is changing so fast out there. Without this fast tumaround the photo isn't going to do you much good.

"Basically, you might say we're selling the technology through the back door by using it as an in-house tool for our scouts. The farmerour customer-sees the results and knows it [infrared] works." Does Coash foresee the day when they'll sell it directly again? "Somedaymaybe. If we do, we'll go back to the dual system of photography. The conventional color helps the farmer recognize his own field. It also gives him a comparison to see what the infrared is doing."

\section{Timing}

Most of the infrared photography is taken by Coash, Inc. during the months of June, July and August. On a typical day the company Cessna will deoart its runway with its pilot Larry Ebert and Don Coash aboard at 10 a.m. and make its final landing approach of the day at somewhere around 4 in the afternoon. "Of course, the weather has to be clear," Coash says. "We'll cruise at around 4,200 feet and I'll point out to Larry the fields we want to shoot. As I've said, we've hit over 100 fields on a good day."

What is looked for will vary by month, as Coash explains it. "In June we're looking for water patterns and weeds. It's easiest to spot them [the weeds] at this time because the corn plants haven't grown enough to obscure them. The water patterns are also critical at this stage because moisture stress can greatly affect yields later on. In July, we're again looking at water patterns-it can get awful hot and dry in stretches-and by August 
"The cost-excluding the aircraft," which brings a smile across the face of Coash, "is not prohibitive

Coash jerrybuilt a platform for two $35 \mathrm{~mm}$ cameras and talked a friend of his into using his Super Cub to make the overflights. "I set the
Though pleased with his early results, Don Coash soon discovered there was ample room for improvement. "You learn by doing," remarks Coash. "It was not long be- for getting into this. I'd estimate we have somewhere in the vicinity of $\$ 900$ wrapped up in cameras and filters, excluding the film we have to

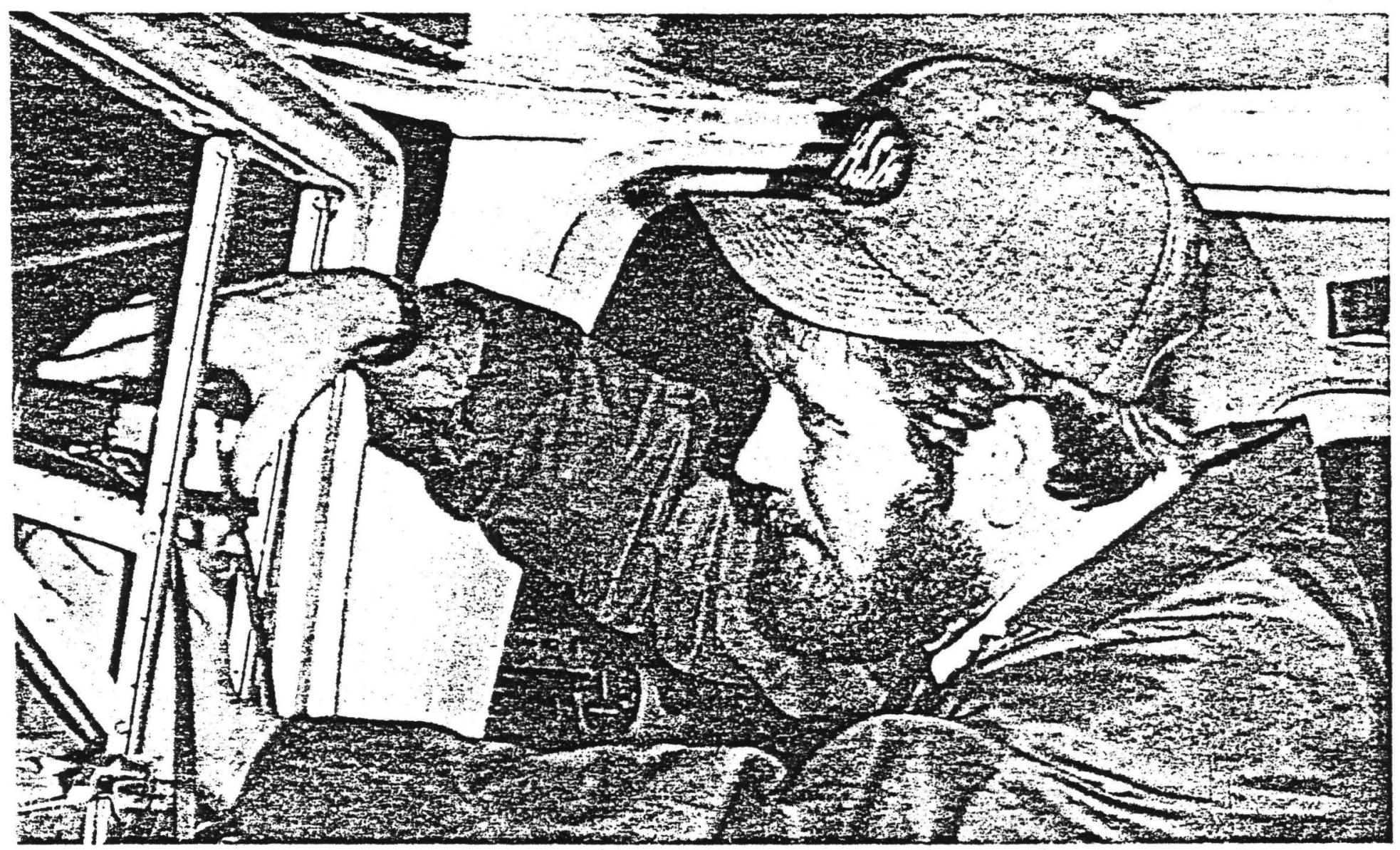

CUSTOM-MADE DOOR MOUNT ON Cessna 182 owned by Coash, Ine. locks $35 \mathrm{~mm}$ camera into vertical, $90^{\circ}$. po-ground posifion for intrared photography of customer's fields. Positioning eamera is Don Coash who has spearheaded project for the company.

cameras up so I could trip them both at the same time," explains Coash. "They were lined up to shoot at the same thing. One camera had infrared and the other had standard color. We removed the back window and I literally hung out the window to make the shots. The results really got us excited. They showed up things that we had suspected for a long time. Water patterns jumped out like a sore thumb. In the areas where we didn't have the deeper red-these are the healthy plants-we knew the farmer had poor water patterns and that his crop was under stress. You see, our sandy soils up here can only hold an inch of water in the top 18 inches, so if you don't get that inch of water when you need it you've got a yietd loss. It's important that you spot this eariy and this is where infrared heiped." fore I discovered the infrared was picking up heat trails from the air. craft's engine when I hung out the window to take the shots. Of course, this is going to distort the picture you get." The solution came along about the time Coash, Inc. decided to invest in a Cessna 182. "The aircraft has a high wing and we decided to use a more professional type of mount for the camera-we'rs using just one camera now," Coash continues. "We bought a custom door for the aircraft and had it fitted with a special bubble window and fixture in which to mount the camera. It points straight down and is fitted with a sport finder viewer for the pilot, along with a trigger extension for the shutter. This got rid of the heat trails problem, plus made it a lot easier to control and manipulate the camera to get what we want. buy. If you don't haye your own aircraft, you can figure-at least around here-to pay something like 555 an hour to rent one. To give some idea of the potential for payback, I can remember one fivehour day when we photographed over 100 fields."

While Coash, Inc. charged initially for its phorography services, it dropped the practice after the first year. "I'm not going to elaborate on this other than to say we overextended ourselves-and I'd caution anyone thinking of getting into this in that regard," says Coash. "We were growing at such a clip we simply didn't have the time to produce the three sets of photos we promisedthis can happen to anyone. So we decided not to charge our customers." 


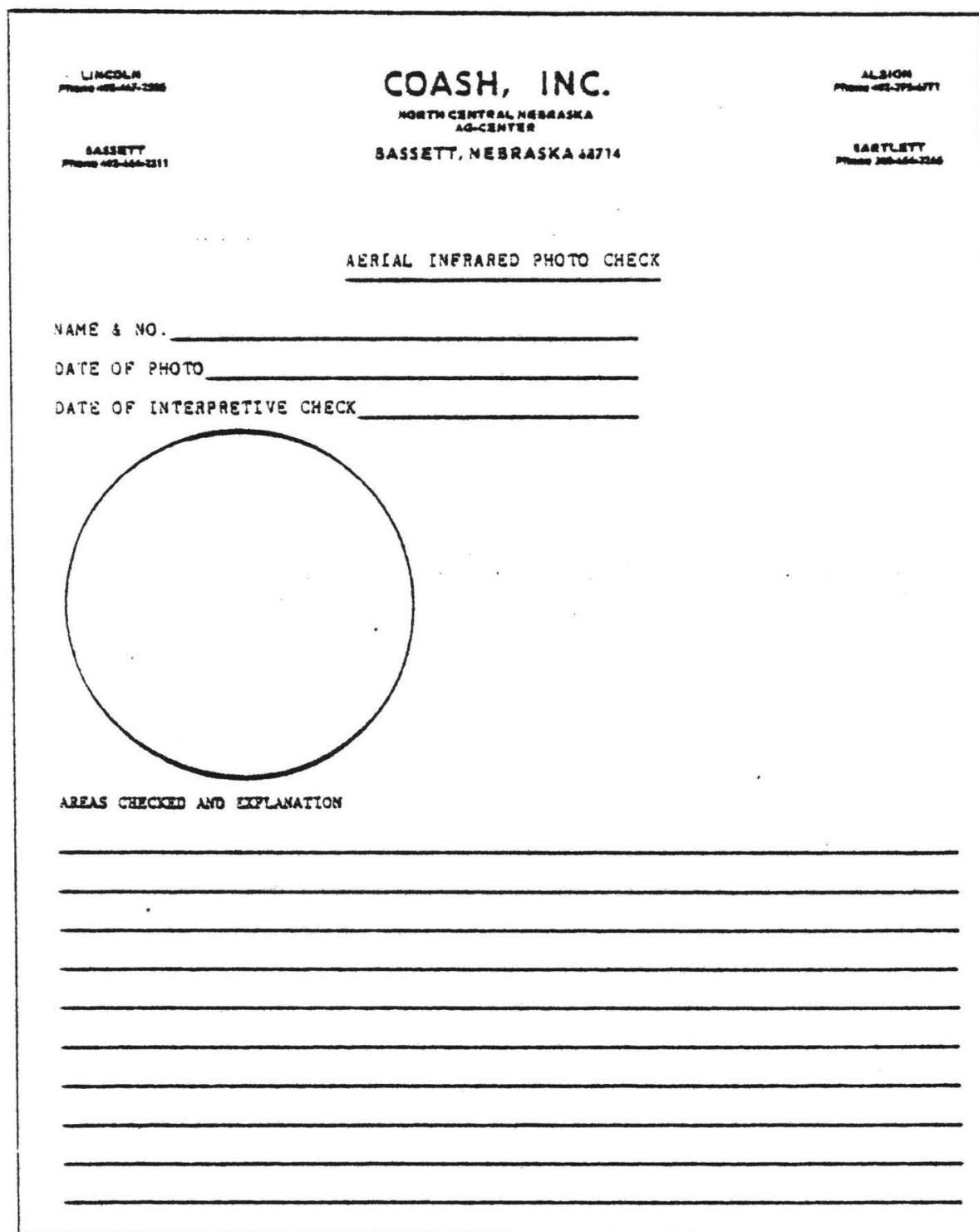

PHOTO CHECK FORM is used at Coash, Ine. in maintaining thorough record check and history on each of its customer's fieids.

we're looking at water patterns as well as for plant disease and insects. This dovetails beautifully with the irrigation systems out here because with the pivots we can adjust our fertility program throughout the season."

\section{Interprating}

The process of infrared is about as good as the interpretation put on it, Coash pointedly observes. "I'll give you an example. We had a customer whose field showed poor water patterns on the infrared. Well, he had been going along doing the obvious-fixing broken push bars or cracked pipes. Still, we knew the infrared was right. Sure, his sorinklers were all working but he didn't take the time to take a closer look at them. What we found was that traces etse was wrong. We went back into the field and found colonies of army worms. We llew on an insecticide and that was the end of them.

"Generally, I'd say the deep red areas are where you have your healthy crops, the purplisin areas are where the weeds are, the black spots are water holes and the lighter areas can be a combination of thingseverything from planter problems to moisture stress or disease. You've got to go into the field to pinpoint the problem."

\section{Biggest Advantage}

There is one benefit that stands above all others in the mind of Don Coash whenever he discusses the salieat points of infrared photog. raphy. "Soil identification would bave to be our number one advantage," Coash states. "Patches of soil or old fields readily show on the infrared film. If we had a fairly fertile soil to start with - with plenty of everything in it-it wouldn't be so critical. But where we've got to apply about everything we use you've got to identify these soil types so you don't end up over-fertirizing one soil and under-fertilizing another.

"So the infrared tells us where we need to be soil sampling. Where the soil type is different, it needs to be treated differently and this we can identify with infrared. It makes these photographs a very effective tool in our heiping the farmer to property manage his farm."

\section{Biggest Disappointment}

If there's one flaw or disappointment Don Coash has experienced with infrared it lies in the area of spotting nutrient deficiencies. "We originally thought we could pick out nitrogen deficiencies or phosphate deficiencies, but I don't think with the quality of film we use we can pick it up," Coash says. "I've heard others say they can, but that simply basn't been the case with us. It's such a delicate art that even a little haze later in the day will change colors enough to make readings impossible. Admittedly, with a densitometer that measures the density of negatives we might very well be able to read nutrient deficiencies. But the equipment is very expensive."

\section{No Panacaa}

When drawn out, you'll find Don Coash holds some very definite and strong opinions about the place infrared has in agriculture. "I think 
it should be used as a management tool, not as a panacea," he'll state crisply. "If there's anything that puts a black mark on this practice it is to sell it as a panacea-and it tears me up when I see it happen.

"But by using it as a management tool, a farmer can become as well acquainted with his field-drainage areas, soil types, infestations-as the back of his hand. That is how the practice should be viewed-as a device to control potential problems. It's not going to eliminate them all."

Coash also has advice for any new. comers who may adopt the practice of infrared. "This practice is not hard to get into but," he warns, "whoever does better be prepared to spend a lot of time on it. As I've said, it can be a tricky business and if you don't develop the proper skills, handle it on a professional basis, you can lead a lot of people astray.

"The real bottom line is this has been making us money, however indirectly that may be. It makes those ground troops a lot more effec. tive, vastly cuts their time. They can spot a problem on the photo and walk right to the problem area." (4.
EDITOR'S NOTE: Sources of further information on high- and low-altitude biosensing include:

EROS

(Earth Resources Observation Systems) Sioux Falls, South Dakota j7198, USA.

Products processed at the EROS Dasa Center include aerial pholographs (inirared and other types) obcained for:

- the United States zovernment

- NASA research aircraft

- Skylab, Apollo, and Gemini spacecraft

- Landsat

All products are available for purchase.

Aerial Biosensing Association City National Bank Building

Omana, Nebraska 68102, USA

The group provides training courses for photographers and interpreters and will serve as a forum for exchange oi concepts, techniques, and know-how.

Dr. A. D. Flowerday

University of Neobraska

Department of Agronomy

Lincoin, Nebraska 68508. USA

Dr. Flowerday is a trained agronomist and experienced interpreter. 


\section{Infrared photography for agrioultural production management \\ by Calvin Kuska}

Visual inspection of crops does not always yield information about growth conditions. By using a technique involving aerial infrared photography, agricultural managers can detect special problems, such as poor irrigation or uneven fertilization.

TURING WORLD WAR II a Special film was developed by the United States Army that was used to distinguish camouflage from natural vegetation. The same film was used during an Apollo IX manned spacecraft light in 1969 to analyze vegetation and drainage in the Imperial Valley in Califomia, USA, and Mexico. The film, false color infrared, can also be used today to provide an overview of the entire vegetative growth process.

Unlike normal color film, false

Mr. Kuska is an industrial marketing consultant with the firm Markon Associates in Nebraska, USA, and executive secretary of the Aerial Biosensing Association. color infrared is sensitive to a portion of the electromagnetic spec. trum that is invisible radiated energy. This energy encompasses a large baind of wavelengths longer than the most extreme visible red (figure 1), from 700 nanometers (nm) to 1 million or more $\mathrm{nm}$ (a nanometer is one billionth of a meter). The longest wavelength of infrared radiation recorded on film is about $1350 \mathrm{~nm}$, however, the most common applications of infrared photography are in the region between 700 and $900 \mathrm{~nm}$ (figure 2).

The three emulsion layers of infrared film are sensitized to green, red, and infrared wavelengths, rather than to blue, green, and red wavelengths. A yellow filter (Wratten No. 12 or No. 15) withholds the blue rays, to which these layers are also sensitive. Of course, the visible spectrum aiso becomes a part of the infrared record. When processed, a yellow positive image records in the green-sensitive layer, a positive magenta image appears in the red-sensitive layer, and a cyan positive image appears in the infrared-sensitive layer.

The infrared record

All objects either reflect or radiate infrared energy. Healthy plant foliage, for example, reflects a

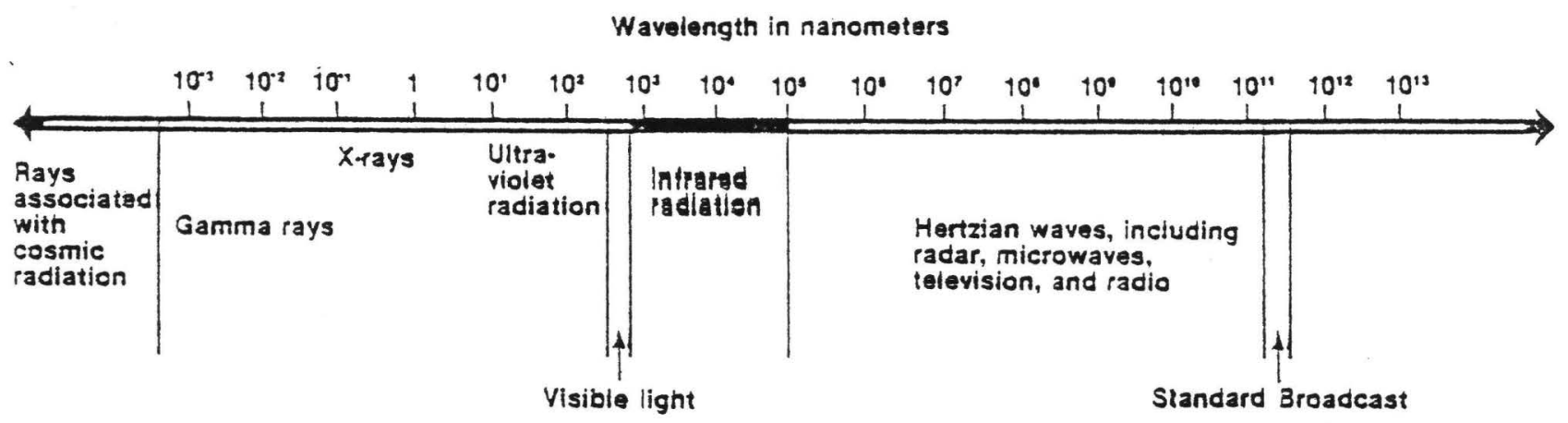

Figure 1. The electromagnetic spectrum. 

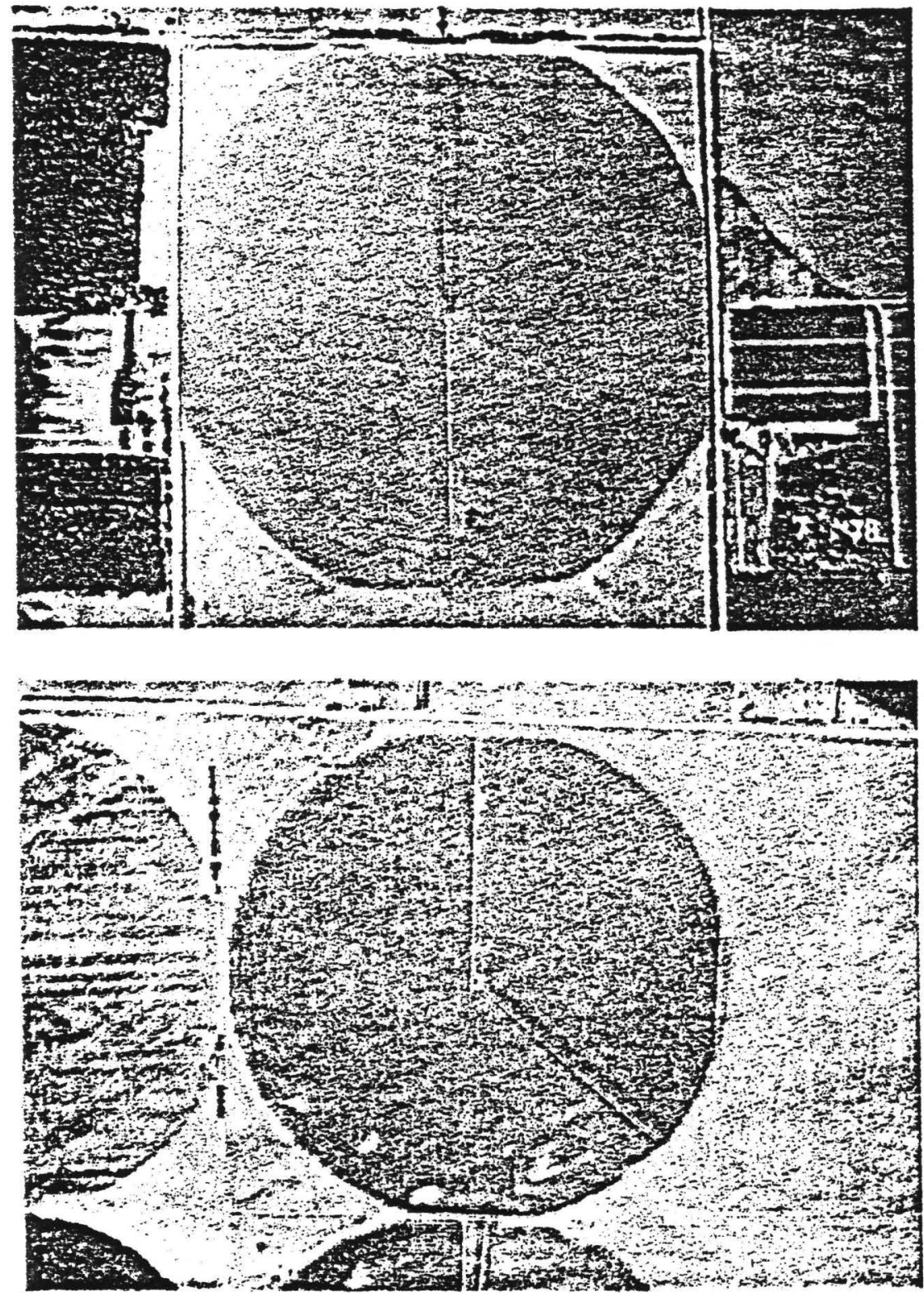

tation to sense the heat radiation coming from it. The radiation is then transiated to a temperature reading. Evaporation from plant leaves cools the air at the lear's sur. face. When soil moisture is low, this evaporation is reduced because less moisture moves through the plant, and consequentiy, temperature rises at the lear's surface. This same technique can and probably will be adapted to large scale aerial work, because in all types of crop monitoring, often the closer you get the less you see.

Other advances in the field that are still in the experimental stage include the use of automatic digitiing systems for analysis, remote television cameras and monitors to eliminate the need for a photographer in the airplane, and remote mount camera pods that will fasten to the underside of a small plane without affecting the flight characteristics or certification requirements.

\section{Aerial biosensing applications}

A commercial firm in the USA with several years of experience in infrared application has photographed such crops as maize, alfalfa, sugar beets, potatoes, sorghum, and ormamental trees. The firm provided the sarvice to nearly $20 \%$ of the potato crops in one
Water application and drainage in this field are excellent. However, the dark spots in the field in the upper right indicate that there has been an application of 100 much water and as a result, yields will suffer.

\begin{abstract}
If everything goos well, the circle of center givot irrigated maize will oroduce a yiald above 375 bushelsihec. iare. The loft-hand halt-circle of maize is saveral days later in germination, so the crop covering is not so complete. However, it does show some serious streaking, which is caused by improper application and compaction from a dry fertilizer soreader. When measured at harvest time, the loss in the light areas was approximately 50 bushels/hectare.
\end{abstract}

Color phorograons courtesy of OMAX Biesensing. Omana, Neoraska, USA. state with outstanding results. Initially, they started photographing the crop eyery 14 days, but at the end, the potato growers wanted these infrared photographs every seven days of the season. The data infrared photographs provide are especially beseficial with crops that have short growing seasons such as potatoes.

An additional use of low-altitude infrared filming is to determine what undeveloped lands are suitable for food production. By taking photographs of uncultivated areas, the type of natural vegetation it supports can be determined. This will enable the interpreter to predict the kinds of crops 


\section{USES OF INFRARED PHOTOGRAPHS}

\section{During the growing season}

\section{Mid.growing season}

\section{Pre-harvest}

\author{
Post-haryest \\ Throughout the \\ season
}

\author{
To determine field surface conditions and cover \\ To obtain soil type and pattern information \\ To check condition of terracing, grassed waterways, and drainage needs \\ To find or identify tile drainage lines and check their function \\ To check germination success and stand establishment \\ To check effectiveness of pre-emergence herbicides \\ To see indications of environmental problems (insects, disease, or weather) \\ To detect equipment failure or human error
}

To check on stand growth and develooment

To detect evidence of plant loss or damage due to adverse moisture conditions

To discover misapplication of chemicals

To locate insects and diseases

To monitor the effectiveness of herbicide treatment

To evaluate natural or engineered drainage

To estimate forage availability in pastures

To determine distribution of irrigation water

To check stand condition and maturity

To estimate acreages to be harvested and yields

To locate lodging. heavy weed infestations, or other potential problems for narvesting

To determine uniformity and percentage of ripening

To determine total area harvested

To check field cover in harvested areas for weed and volunteer regrowth pat. terns

To document special situations (flood, tornado, hail, drought, or other types of damage) through the belly of the plane, eliminates distortion of results and provides the best overall view and most interpretable photographs.

The photographic day should not be cloudy; howeyer, uniformly overcast days can yield photographs of interpretative quality. For uniformity from one day's shooting to the next, the photography should be accomplished between 10:00 Aill and 2:00 PM, since the sun's ultraviolet rays can also affect the colors of the photograph.

Infrared film is developed using processes like the Eastman Kodak E 4 or EA-5 process. Directions for processing are usually printed on the film package or included in the box. For best results, the same processing tecinniques and processor should be employed throughout the entire crop monitoring sea. son. It should be noted that no safelight can be used during developing. Unlike regular color film, infrared film is sensitive to the red safelight used in most darkrooms and exposure to it will ruin the film. It is a good practice to process the film immediarely after ex- posure to avoid unwanted changes in the latent image. Another reason for developing the film soon after the shooting session is that the grower needs to know where an abnormality in his crops is occur. ring so corrective action can be taken immediately.

\section{Interpretation}

Since interpretation is more an art than a science, interpreting infrared records requires both exper. ience and a technique known as 
This photograph of a eotato crop shows its center pivot irrigation sys. tem. The water application by the sprinkfer arm is apparent. All of the sprinklers are operating efficiently, and the field looks relatively uniform. There is some vertical streaking, which was caused by lack of uniformity in fer. tilizer application. The dark area at the lower right corner of the photograph, behind the date, shows the effect of cloud cover.

The bluish-gray discoloration in this photograph indicates dead or dying olant tissue. This crop has not reached its physiological maturity, but there is apparently something stressing it. Ground truthing indicated that wilt was spreading through the field. On the neighooring field's aerial spraying was used to stop the spread.
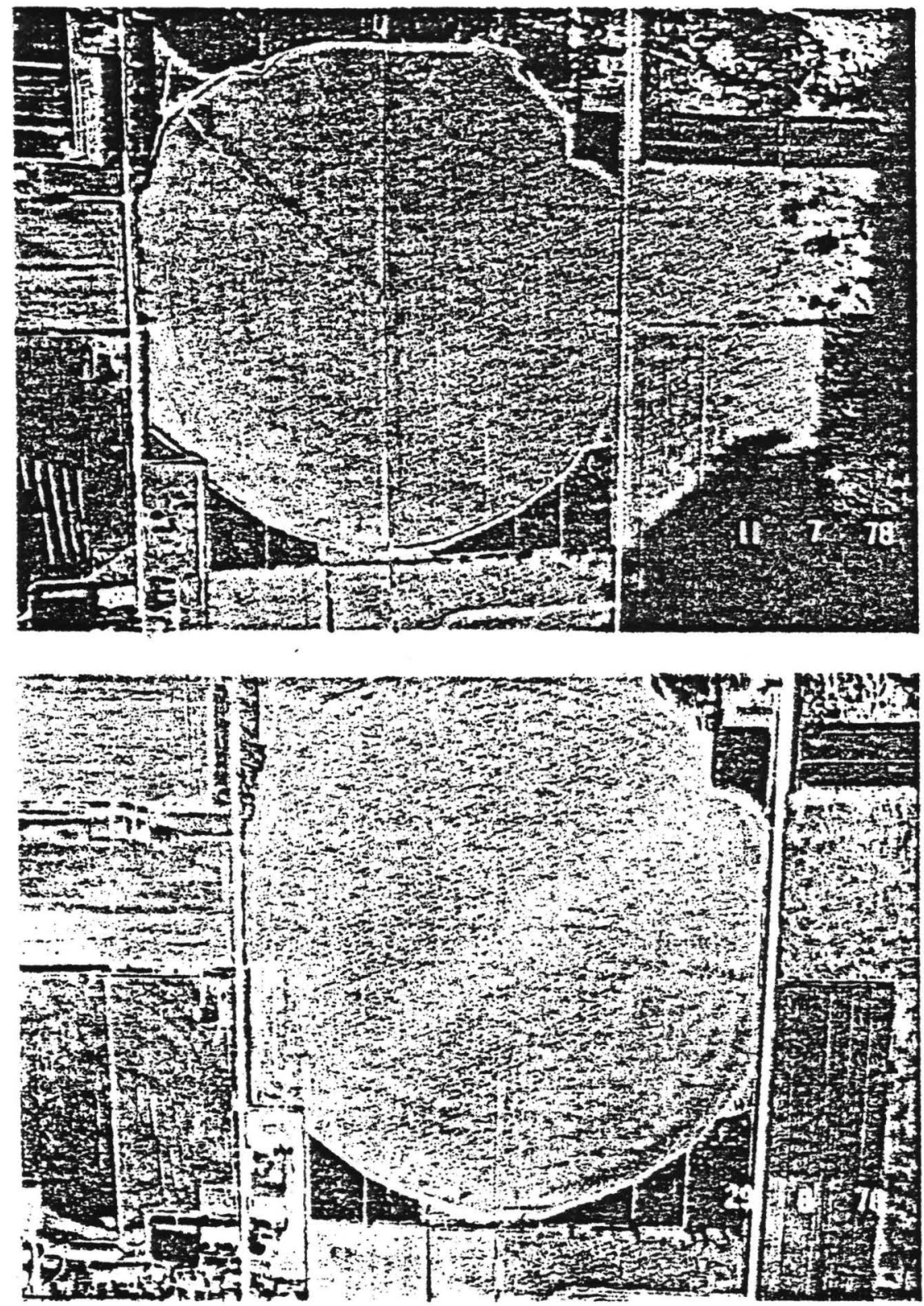

continued from page 102

ground truthing (comparing the photographs to actual field conditions). With some training, the interpreter can easily recognize any plants that are under stress. With some experience in photo interpretation, the scout or technician can also estimate fairly accurately the causes of stress seen in the photographs. Placing a grid over the photographs allows quick calculations of the size of the stressed areas.

All aerial photography requires some ground truthing to verify analysis, but the time needed for such checking can be reduced using the photographs to locate problem areas. The photograph identifies areas of stress, but only after extensive experience and with the help of historical data can the photo interpreter identify the exact cause of the problem. Some stress points are quite obvious as to cause; others are more subtle and may require soil and tissue tests to allow final determinations.

One way to gain interpretation experience is to walk the field or grove with the infrared photograph in hand, observing the relationship between ground conditions and their corresponding appearance on the color infrared photograph. The other is through educational guidance by trained agronomists like Dr. A.D. Flower- day of the University of Nebraska, USA, who has been advising students as well as using the infrared technique to monitor experimental test plots for himseif and colleagues. Flowerday believes that within a few years, producers may lean more towards heat sensing rather than infrared to detect crop conditions, but at present, the heat sensing iechnique requires extremeiy expensive electronic equipment, much of which is very experimental in nature.

Experimental work has been conducied using a hear sensing hand-heid gun that shows absolute temperature reading. This infrared thermomeser is pointed at the vege- 


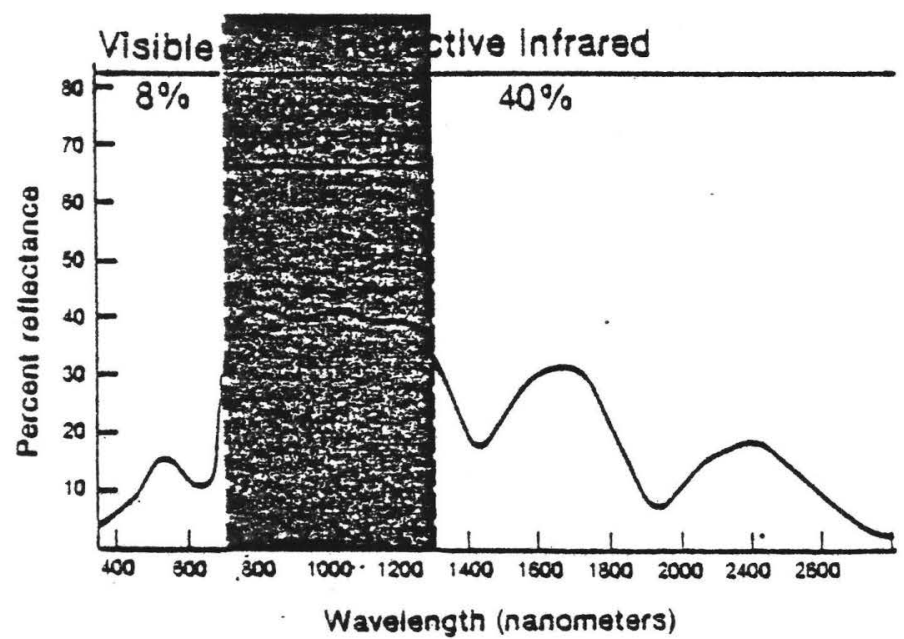

Figure 2 Only about $8 \%$ of the total energy reflected from a green leat is recorded on natural color film. Using color infrared film, nearly $40 \%$ of the reflected energy is recorded.

Figure 3. Intrared monitoring is like taking an x-ray of a olant. Visible light is reflected from the leaf's surtace, while infrared wavelengths are reflected from the leat's interior. This exaggerated cell cross sec. tion shows that about half of the energy goes through the top layer, peflects off the wet cell walls in a random pattern, and bounces back out the top. The other half reflects off the cells and departs out the bottom. About $2 \%$ is absorbed by or rellected off the surface.

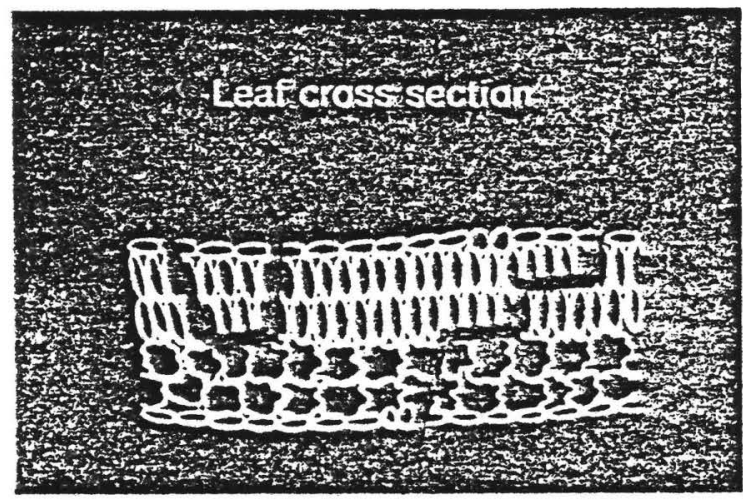

great deal of infrared energy (figure 3). Water, on the other hand, absorbs it. In addition, each living thing displays a unique pattern of radiation (called a signature), so that when photographed, weeds, for example, can be distinguished from a wheat crop.

Since moisture absorbs infrared radiation, certain crop conditions can be discovered from studying an infrared photograph. A leaf that is dying (i.e., has a low moisture content) will appear green to the casual observer. This same leaf will appear brown, or even white in an infrared photograph (depending on the amount of moisture the plant still contains). In addition, because the leaf is stressed in some way (diseased, pest infested, or otherwise in trouble), it begins to curl. This reduces the plant canopy (the coverage of the ground), and also reduces the plant's reflectance. As a result, the film records the reflectance of the ground beneath the plant, revealing an anomaly in that area of the field.

This property of infrared film to record energy reflected from a sub. ject encouraged the development of an entirely new industry-aerial biosensing. Properly applied, the techniques of aerial biosensing can give a farm manager several days notice of a failure in an irrigation system, for example, before he might normally be aware of it. Aerial infrared photography of vegetation can provide agricultural managers with an opportunity to view lands from the air in a single image, enabling them to use a single color photograph to observe an entire area of interest with any amount of detail.

\section{The tools of aerial biosensing}

A smail airplane, much like one used for crop dusting, a $35 \mathrm{~mm}$ camera, and color infrared film are all that is needed to begin employ. ing this technique. Any size field can be accommodated by using various camera lenses and aircraft altitudes. The camera should be capable of providing speeds of $1 / 125$ or $1 / 500$ of a second or faster (any good $35 \mathrm{~mm}$ camera will have faster speeds than these). A metal lens cap, rather than a rubber one, should also be used to prevent infrared leakage that may spoil the film.

Color infrared film is currently ayailable in $35 \mathrm{~mm}, 70 \mathrm{~mm}, 127$ $\mathrm{mm}$ ( 5 inch), and $230 \mathrm{~mm}$ ( 9 inch) sizes. It is affected by heat, so it is important to store any unexposed film either in a freezer or refrigerator to prevent color changes, and to keep it cool after exposure. It should be removed from the freezer and placed in the refrigerator at least eight hours before use, and removed from the refrigerator about an hour before use to prevent condensation of atmospheric moisture on the cold film. When transporting the film, exposed or unexposed, the use of a cooler is advisable. Loading and unloading of the film must be done in total darkness.

The flying altitude should remain the same for the entire season to provide uniformity in the photographs. The photographs can be taken through the side window at an oblique angle; however, for the best results in interpretation, a vertical photograph is recommended. Vertical photography, taken 
that can be planted and grown there successfully.

Aerial remote sensing of crops records an inside view of the growing vegetation, providing a wider range of normal and abnormal differentials than are visible to the human eye. Ground surveillance will not be eliminated, but instead can be more effective with a meaningful photograph that enables interpreters to locate and identify problem areas. This means that more time can be spent taking corrective action before an entire crop failure oceurs. This knowledge can then be passed along to the individual farmers who want to control the pest, disease, moisture, and soil tilth for their crops.

One major benefit of biosensing is the tremendous savings that can be realized in fuel, irrigation water, chemicals, ground compaction, and labor. To date, rellective infrared photography is the most economical method of monitoring crops. 


\section{Infrared Photos Prove Boon}

By RICK LARSON

Of the East Oregonian

$A$ bird's eye view through infrared film is paying off in Columbia Basin farming.

For the past four years personnel from Crop Protection Inc. of Umatilla have provided farmers with a unique service flying over their fields at 6,000 feet and taking infrared photographs to record the condition of their crop.

Martin Pitney, president of the company, ezplained infrared film picks up radiation from the sun which is reflected by plants. The healthier the plant, the more inirared radiation is picked up on film.

A healthy irrigated circle of potatoes will appear bright red once the infrared film is processed, Pitney explained.

However, he said if the plants are stressed at all because of rater problems, soil variation, nutritional deficiencies, disease or pest damage, color variations show up in the photographs. Depending on the cause, the stressed areas will show uo as dull. red, pink, grey or black.

Pitney said it is difficult to leam to correctly inter. pret the different color shades because it requires knowledge of the field and the crop. Uniformity in processing the infrared film aiso is extremely important, Pitney said, and a special film processor is used to guarantee this.
Pitrey's company was one of a few pioneers in use of infrared technology in farm consulting. Prior to that, the main uses of infrared photography were by scientific institutions and the military.

Pitney, 34, went to work for Amfac Corp. in Hawaii after getting his degree in entomology from the University of California at Davis. There he used aerial color photography to observe the company's sugar cane crops, which grow too tall for groundlevel observation.

In 1971 Pitney transfer. red to eastern Oregon where Amfac had bought Columbia River Farms. He had experimented with infrared photography in Hawaii, and in 1975 he decided to start a business based on it.

Now Crop Protection Inc. employs four persons: Pitney, field worker Earl Perkins, darkroom techni-

cian Launne Ankney and secretary Kathy Franks. The company does mork for roughly 30 different firms, photographing about 100,000 acres this season.

Photographs are taken of most crops on a preakly basis. Pitrsey said the cost per acre is about the same as a farmer gets for 50 pounds of potatoes, and he said most find the service 7aluable because of that it can mean to them in sayings.
Water is a prime concern in this region, and the infrared photos show water uniformity problems such as excessiye (standing) water, too little water, im. proper nozzling, plugged sprinklers, spoking and start-up problems.

Pitney points out that with a center pivot irrigation system, one sprinkler covers three to five acres. He said if it is plugged for just one week the grower can lose a lot of that crop.

The infrared photos can reveal plant stress due to insufficient watering seven to ten days before it would be evident by ground in-

spection, Pitney said.

"Aerial photography has a tremeadous amount of uses," Pitney said. "It gives you something that's there.... picture is worth 1,000 words."

Pitney said the infrared photos also help growers detect fertilizer or chemical application problems - sometimes for litigation - and to pinpoint areas where disease or insects have hit. Some growers use the photos to show a soray pilot where to spray.

The infrared photos also give the farmer a reekly record of, his crop. This can be used for field to field comparisons - or to compare areas where different chemicals or seed were used within one field.

$A$ big advantage of using infrared photography which Pitney pointed out is it takes a grower only about an hour a week to evaluate his crop. A 10,000 acre farm can be covered in $50-75$ photos.

Columbia Basin farmers generally haven't been skeptical of the infrared technology, according to Pitney. In fact, he said many were anxious to give it a try.

Others were fairiy easily convinced of the use for the photos by showing them photos of their own fields and pointing out problem areas, Pitney said. He said after they used it a while

they found the service valuable in making management decisions which help them improve their profit marzin. 


\title{
A Comparison of 9-Inch, $70 \mathrm{~mm}$, and $35 \mathrm{~mm}$ Cameras
}

\author{
Small-format cameras can obtain simultaneous color and \\ color-infrared photos more economically than standard \\ mapping cameras and they may be entirely adequate for \\ environmental mapping.
}

\begin{abstract}
Dhotocrapms originally were used only to 1 provide visual pictures of some object or scene. Little effort was given to make the picture metrically correct (the position of points correct) until such cameras were used in making maps. Over the years great effort has been put into manufacturing mapping cameras that can provide as nearly perfect a perspective image as possible in order to determine the position of an object with ac-
\end{abstract}

large, utilizing 9 -inch film formats. Further, they are very expensive, sometimes costing more than the aircraft that carry them. Their large size allows only one camera to be used through a camera port in the floor of the aircraft; if simultaneous photography is needed, another camera port must be cut and another camera obtained.

When color and color-infrared film began to be used for mapping of environmental fac-

\begin{abstract}
Asstract: Successful aetial photography depends on aetial cameras that provide acceptable photographs within the cost restrictions of the job. For topographic mapping where ultimate accuracy is required, only large-format mapping cameras will suffice. For mapping environmental patterns of vegetation, soils, or water pollution, 9 -inch cameras often exceed accuracy and cost requirements, and small formats may be an overall better choice. In choosing the best camera for environmental mapping, relative capabilities and costs must be understood.

This study compares resolution, photo interpretation potential, metric accuracy, and cost of 9 -inch, $70 \mathrm{~mm}$, and $35 \mathrm{~mm}$ cameras for obtaining simultaneous color and color-infrared photography for environmental mapping purposes.
\end{abstract}

curacies approaching $1 / 10,000$ of the Hying height. This means that photography taken 1000 feet above the terrain can be used to measure the correct position of an object on the ground to within 0.1 feet, or approximately one inch. ${ }^{1}$

Such cameras, together with the manner in which error effects have been accounted for, bring credit to the technical expertise of those who develop and manufacture them. However, there is a price to pay for such perfecton. Viodem aerial mapping cameras are tors, it was common to take such photography with the 9-inch cameras which were well established for accurate topographic mapping purposes. However, for mapping of environmental factors such as the aporoximate boundary of a tree or grass type, a soil type, or a water pollution plume, such mapping usually requires accuracy in the tens of feet and does not require the fraction-of-a-foot accuracy necessary in topographic mapping.

For environmental mapping, it is almost always desirable to obtain simuitaneous color

PHotocrammetric ENGinesRing and ReMOTE SENSINC,

Vol. 41. No. 12, December 19i5, pp. 1487.1500 
and color-infrared photos. This requires two cameras. Host mapping aircraft are set up for one camers only and therefore two separate flights are necessary. This introduces a time lag into the monitoring as well as additional cost. Strandberg in 1963 suggested that $35 \mathrm{~mm}$-format cameras could be used for much environmental analysis. ${ }^{2}$. Marlas and Rinker in 1967 indicated the economy and versatility of doing such work by using $70 \mathrm{~mm}$ cameras. $^{3}$ Four cameras were employed in their work through one camera port. Other work has indicated that although nine lenses, four cameras, or three cameras may provide valuable additional data, two cameras utiliz. ing color and color-infrared film adequately cover all wavelengths needed for environ. mental mapping. Color film which combines blue, green, and red images into one composite color photo can be used by interpreters better than the three individual black-andwhite photos taken in the blue, green, and red wavelengths. Finally by projecting this color film through blue, green, and red filters, one can recreate the corresponding three blackand-white bands. A microdensitometer can also be used to obtain the intensity in any band. 4

With color-infrared film, one is in effect creating a composite photo with green, red, and infrared images. These also can be separated by projecting the resulting photo through blue, green, and red filters. Ishaq ${ }^{5}$ has projected $35 \mathrm{~mm}$ film through a $\# 27$ Wratten filter onto a base map and very effectively mapped high-moisture soils which show up as dark on the infrared image which is preserved in the color-infrared film. These pattems were not visible to the interpreter unt the photo was projected through this red filter, which then created in effect a blackand-white infrared photo. This technique also can be used for any other desired wavelength of photographic energy. Infrared energy (image as red on color infrared film) is especially useful in environmental work such as vegetation studies, and also water quality monitoring, because it penetrates very little into the water. ${ }^{3}$ The blue and green images on the color film are especially useful in water quality studies because they do penetrate well into the water. Normal color film is also very valuable for photo interpretation work because it provides a true-to-life image.

The conclusion here is that two cameras, one containing color and one containing color infrared film, give the optimum combination for analysis of the environment by remote sensing. The assumption was therefore made in this study that a two-camera system was the optimum for environmental mapping.

At the University of Wisconsin, two $35 \mathrm{~mm}$ bulk-film motorized cameras have been in use since 19 T0 for environmental monitoringi (see Figure 1). In addition to the economics of such a svstem, the resulting $35 \mathrm{~mm}$ bulk color and color-infrared film is in effect microfilm and a remote sensing library has been set up for cataloging, retrieving, and viewing such film. ${ }^{3}$ Figure 2 shows such bulk $35 \mathrm{~mm}$ color-IR film being projected onto a rear projection screen in order to extract environmental data. This system has been very successful both in research and in teaching of environmental monitoring by remote sensing. Gustafson (1973) has very effectively used this system for mapping of aquatic weeds. ${ }^{9}$ Although cost and data handling advantages of the $35 \mathrm{~mm}$ format are obvious, the question always arises concerning its resolution potential and metric accuracy, especially as compared to $70 \mathrm{~mm}$ film. Some inves. tigators prefer to use the 9 -inch format because they feel much more comfortable with its theoretically better metric accuracy and resolution, and perhaps because of the tradition of use.

of course according to accepted theory,

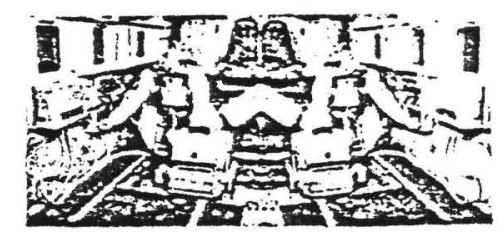

Ineh soreer smess

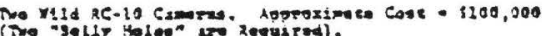

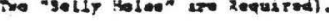

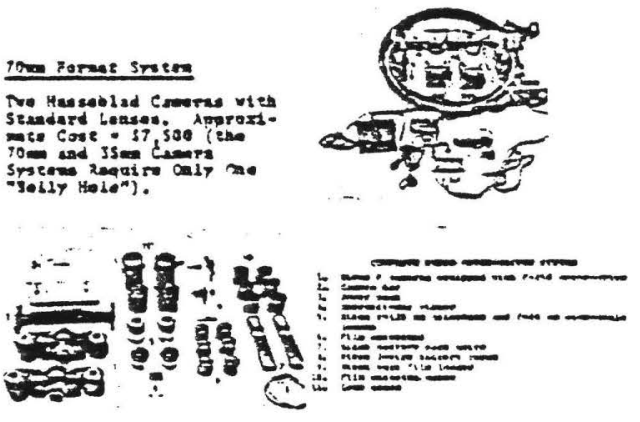

ism paras susten

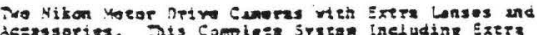

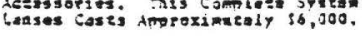

Fic. 1. Comparison of $Q$-inch, $70 \mathrm{~mm}$, and $35 \mathrm{~mm}$ equipment for obtaining simultaneous color and color infrared photography for environmental mapping. 


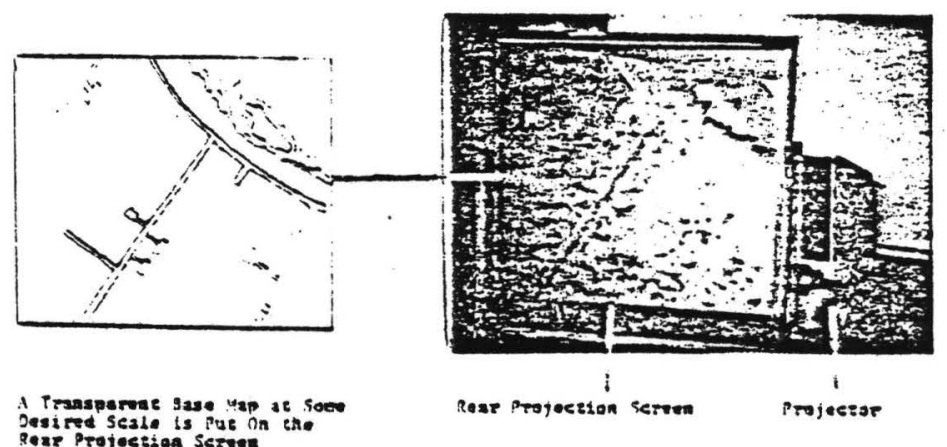
Tesired seale is put on the

Fic. 2. Projecting a $35 \mathrm{~mm}$ image onto a tiltable rear projection screen. The projected image is made to match the base map. Environmental detail on the photo is then traced onto the map. This figure shows bulk $35 \mathrm{~mm}$ film being projected by a Kodak Recordak Motormatic microfilm viewer which has the screen removed. If the $35 \mathrm{~mm}$ film is made into slides, these can be projected by standard slide projectors.

metric accuracy, resolution, and photo interpretation ability should be superior on the Finch format compared to the $70 \mathrm{~mm}$ format, and better on the $70 \mathrm{~mm}$ format than on the $35 \mathrm{~mm}$ format. But the question is "How much better?" Also, are the theoretical differences in resolution, metric accuracy, and interpretation ability really significant when compared to the difference in cost and ease of use?

To answer these questions, an area of environmental interest was photographed with simultaneous $35 \mathrm{~mm}, 70 \mathrm{~mm}$, and $9 . i n c h$ photography taken from various altitudes, and the resulting photography was compared concerning resolution, photo interpretation potential, metric accuracy, and cost. This paper describes the investigation.

The site chosen was near Madison, Wisconsin in a marshy and wooded area where a new highway was proposed. The Wisconsin Department of Iransportation " was interested in testing the University of Wisconsin's bulkfilm $35 \mathrm{~mm}$ and color-infrared photography system in this area as a means of mapping the environment and monitoring its change. They suggested the study to University of Wisconsin personnel and all agreed that it was an ideal site.

The main environmental elements of interest for this study were soils, vegetation, and water. Experts from the state agencies (Wisconsin Department of Transportation and Department of Natural Resources) agreed to analyze the different-sized-fomat photography concerning photo interpretation

- Engineering Services Section of Wisc. Dept. of Transportation (Vem Schule, Director). potential for soils and vegetation mapping. Resolution panels were laid out and photographed with each camera. Engineering Services of the Wisconsin Department of Transportation already had mapped part of this area by conventional photogrammetric mapping techniques, and this map helped provide the base control for metric accuracy studies.

The area was flown with a DC 3 which had the capability of providing $9-i n c h, 70 \mathrm{~mm}$, and $35 \mathrm{~mm}$ photography simultaneously. The focal lengths for the $70 \mathrm{~mm}$ and $35 \mathrm{~mm}$ cameras were chosen so that approximately the same area was covered by each camera (see Figure 3). The resulting photos were then enlarged and rectified in the same enlarger to bring them to a common scale for the metric accuracy comparison (see Figure 4). The photos were viewed stereoscopically for the photo interpretation tests and resolution studies.

Details of these studies and the cost comparisons follow in this paper.

RESEARCH SPECIFICATIONS AND FIELD WORX

The research area selected for this project was the Mud Lake area south of Madison, Wisconsin. The study area extends 4,000 feet in the north-south direction and 14,000 feet in the east-west direction. Most of the area is marsh with swamp vegetation and sandy soils. The topography is predominantly flat with the lake in the center. The westem sec. tor is under cultivation while the eastern sector contains a petroleum tank fam. U.S. Highway $12 / 18$, which is the south Madison beltline, provides the northem border of the study area.

The flight plan included one light line 


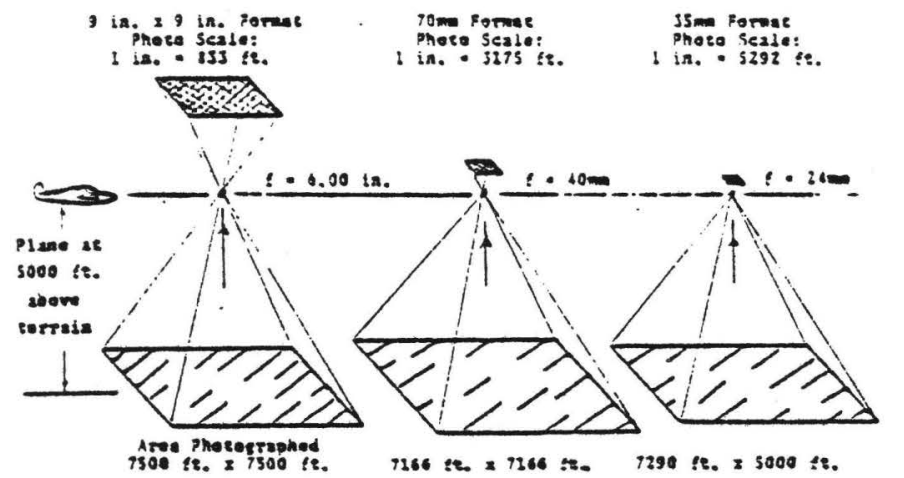

Fic. 3. Acquiring the 9 -inch, $70 \mathrm{~mm}$, and $35 \mathrm{~mm}$ photo graphy for comparison. The above sketch shows the photo scales and the areas covered for a dying height of 5000 feet above terrain. The area of coverage for all three formats is approximately the same due to the proper choice of focal lengths of lenses used on the $70 \mathrm{~mm}$ and $35 \mathrm{~mm}$ camers.

from east to west centered over the research area. These lights were lown at 1000 feet, 3000 feet, and 5000 feet above termin. The speed of the DC3 aircraft was 130 knots. A Nikon $F$ motorized camera with a $24 \mathrm{~mm}$ lens was used to take the $33 \mathrm{~mm}$ photography. A Hasselblad M/EL camera with a $40 \mathrm{~mm}$ wide-angle lens, was used for the $70 \mathrm{~mm}$ photography, and the Fairchild 224 camera with a (Bausch and Lomb Metrogon) E-inch focal length lens was used for the 9 -inch format photography. The films used were Color Infrared 2443 transparency for the $35 \mathrm{~mm}$ imagery, Ektachrome MS transparency for the $70 \mathrm{~mm}$ photographs, and Aerochrome Infrared transparency for the 9 -inch photos. Identical film in all three cameras would have been preferred but was not available at the time of the flight.
With these format and focal length combinations the area coverage on each format is nearly equal as indicated in Figure 3. The scales are therefore markedly different (see Table 1). It was necessary to equalize the scales for the metric accuracy comparison. Figure 4 depicts the rectification-enlarging process used to match the scales of the three formats. For the resolution comparison, resolution panels were placed in the petoleum tank farm area in the easternmost part of the study area (see Figure 5). These white cloth panels were of 15 feet square, 12 feet square, 9 feet square, 6 feet square, 3 feet square, and 1 foot square sizes.

Ground control was required for the metric accuracy comparison. Although the area was mapped at a scale of 1 -inch-equals-50-feet by the Wisconsin Department of Transportation,

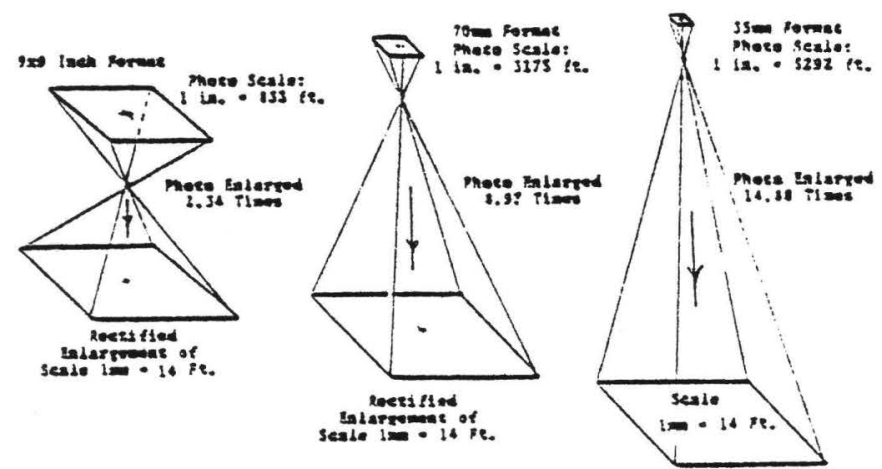

Fig. 4. Rectifying and enlarging the 9 -inch, $70 \mathrm{~mm}$, and $35 \mathrm{~mm}$ photography to a common scale for comparison. Al three format sizes were enlarged in the same rectifierfenlarger to eliminate any differences due to different enlarger lenses. The $35 \mathrm{~mm}$ film was also enlarged with standard slide projectors. 
A COMPARISON OF 9INCH, TOMM, AND 35MM CAMERAS

Table 1. Photocraphic Data for the Thre Formats Flown.

\begin{tabular}{|c|c|c|c|}
\hline & $35 \mathrm{~mm}$ & $70 \mathrm{~mm}$ & Ginch \\
\hline $\begin{array}{l}\text { Camera: } \\
\text { Lens: } \\
\text { Format: } \\
\text { Films: }\end{array}$ & $\begin{array}{l}\text { Nikon } F \\
24 \mathrm{~mm} \\
36 \mathrm{~mm} \times 24 \mathrm{~mm} \\
\text { Color IR } 2443 \\
\text { transparency }\end{array}$ & $\begin{array}{l}\text { Hasselblad .W/EL } \\
\$ 0 \mathrm{~mm} \text { Wide Angie } \\
35 \mathrm{~mm} \times 53 \mathrm{~mm} \\
\text { Ektachrome .MS } \\
\text { transparency }\end{array}$ & $\begin{array}{l}\text { Fairchild } 204 \\
6 \text {-inch } \\
\text { Gin. } \times \text { Gin. } \\
\text { Aerochrome IR } \\
\text { transparency }\end{array}$ \\
\hline $\begin{array}{l}\text { Flying } \\
\text { Heights } \\
1000 \mathrm{ft} \\
3000 \mathrm{ft} \\
3000 \mathrm{ft}\end{array}$ & $\begin{array}{l}\operatorname{lin}_{0}=1064 \mathrm{ft} \\
\operatorname{lin}_{0}=3191 \mathrm{ft} \\
\operatorname{lin}_{0}=5292 \mathrm{ft}\end{array}$ & $\begin{array}{l}\operatorname{lin}_{0}=637 \mathrm{ft} \\
\operatorname{lin}_{0}=1911 \mathrm{ft} \\
\operatorname{lin}_{0}=3175 \mathrm{ft}\end{array}$ & $\begin{array}{l}\operatorname{lin}_{0}=16 T \mathrm{ft} \\
\operatorname{lin}_{0}=500 \mathrm{ft} \\
\operatorname{lin} .=833 \mathrm{ft}\end{array}$ \\
\hline $\begin{array}{l}\text { Flying } \\
\text { Heights } \\
1000 \mathrm{ft} \\
3000 \mathrm{ft} \\
3000 \mathrm{ft}\end{array}$ & $\begin{array}{l}1311 \times 1000 \\
4531 \times 3000 \\
7290 \times 5000\end{array}$ & $\begin{array}{l}1433 \times 1433 \\
4299 \times 4299 \\
1166 \times 1166\end{array}$ & $\begin{array}{l}1503 \times 1503 \\
4500 \times 4500 \\
7500 \times 7500\end{array}$ \\
\hline
\end{tabular}

there was no existing control within the study area other than the plotted features on the map. A field check was conducted to determine the map's reliability. Several points on the map were chosen and the distances between them were measured on the ground with a DiM-60 Cubitape. The distances between these same points wiere then measured on the original Cronaflex map with a glass scale. The map distances were scaled to the ground distance. Discrepancies then were calculated between the known ground distances and distances calculated from the map. The mean discrepancy between the map and the field check was found to be 0.78 feet, well within allowable map compilation error. When compared to the lengths of lines meas. ured this resulted in a mean discrepancy of 0.12 percent (which is a 1.2-foot error in a thousand feet). The accuracy of the map was considered to be sufficient for the metric accuracy comparison. The map was used as a base in the rectification process.

\section{Resolution Comparison}

Resolution, or sharpness, of a photographic image is dependent on the camera lens, the format of the photographs, the type of emulsion, and the shape and contrast of the target. It is of interest to know what size of photographed object can be seen from various flying heights on the different formats. The purpose of this comparison was to show the resolution differences between $35 \mathrm{~mm}, 70 \mathrm{~mm}$, and 9 -inch formats. The shape and contrast of the targets were the same for each format in this study. The flying heights were the same and the format-to-focal-length ratio was as near the same as possible.
An important consideration in comparing the resolution of the different formats is the format-ko-focal-length ratios used to take the photography. The ratio of format-to-focallength can be used to determine whether a lens is normal, wide-angle, or telephoto. These ratios tor the $35 \mathrm{~mm}, 70 \mathrm{~mm}$, and 9 -inch photography must be nearly equal in this study. If the format-to-focal-length ratios are

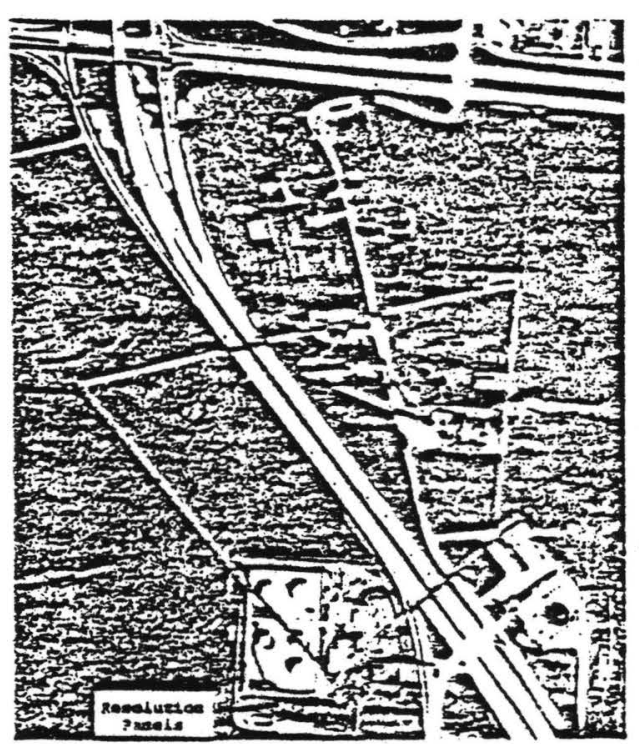

FIC. J. Finch photograph showing the area on which the resolution and metric comparisons were made. The smaller,control triangle demarks the base map controlled area. The quadrilateral shows the controlled area derived from the Q-inch photograph. 
equal, approximately the same area will be covered by each photo.

It was not possible to obtain exactly equal format-to-focal-length ratios for the three camera systems used, but the available equipment provided ratios close enough to make the study acceptable. With the available lenses, the following ratios were established:

$\frac{35 \mathrm{~mm} \text { format }(36 \mathrm{~mm} \text { actual) }}{24 \mathrm{~mm} \text { focal length lens. }}=1.50$ ratio
$\frac{70 \mathrm{~mm} \text { format }(55 \mathrm{~mm} \text { actual) }}{40 \mathrm{~mm} \text { focal length lens }}=1.375$ ratio
$\frac{9 \text {-inch format }}{6 \text { inch focal length lens }}=1.50$ ratio

With these ratios, the object size relationships on the different formats are indicated in Table 2

TABLE 2 OBJECT SIzE DIFFERENCES FOR THE THREX Formats Relative Size to Object on $X$ Format.

\begin{tabular}{crcc}
\hline$X$ Format & $35 \mathrm{~mm}$ & $70 \mathrm{~mm}$ & $9 \mathrm{inch}$ \\
\hline $35 \mathrm{~mm}$ & 1 times & 1.67 times & 6.33 times \\
$70 \mathrm{~mm}$ & .6 times & 1 time & 3.8 times \\
$9 \mathrm{in}$ & .158 times & .263 times & 1 time \\
\hline
\end{tabular}

As indicated, an object on the $35 \mathrm{~mm}$ - and $70 \mathrm{~mm}$-format photos is considerably smaller than on the Ginch photos (if the format-tofocal-length ratios are equal). The question is, to what extent does this difference in size affect the photo interpreters' ability to discem environmental detail when he views the images under magnification and how does this ability vary with the flying height of the aircraft? The resolution study attempts to answer these questions for varying llying heights up to 5000 feet above terrain.

The resolution analysis consisted of merely viewing each image and seeing which panels were visible, and indicating how sharp they appeared on each format for the various flying heights. Each exposure was studied on the University of Wisconsin's Fairchild MultSensor Viewer under six-power magnification. The results are given in Table 3 .

To differentiate resolution of the panels the following descriptive terms were used to establish degrees of clarity (Figure 6 illustrates the appearance of the panels related to these terms).

$S=S H A R P$ - no distortion or fuzziness, comers are acute

$C=C L E+A R$ - fuzziness is minimal, corners are not acute

$B=B L U R R E D$-fuzziness dominates, comers are not acute $\mathrm{NV}=$ NOT VISIBLE-panels can not be seen at all

\section{0-FEET FLYINC HEICHT}

Table 3 shows that at a lying height of 1000 feet there is little difference between the formats with respect to the resolution quality of the panels. On the 9 -inch format the 6 -foot-square panel and the 3-foot-square panels were resolved one degree sharper than on either the $35 \mathrm{~mm}$ or $70 \mathrm{~mm}$ formats.

\section{0-FEET FLYINC HEICHT}

At 3000 feet, the $35 \mathrm{~mm}$ and $70 \mathrm{~mm}$ formats were nearly the same with the $70 \mathrm{~mm}$ format resolving the 15-foot-square panel one degree sharper than on the $35 \mathrm{~mm}$ format. The 9 -inch format was substantially better than both the $35 \mathrm{~mm}$ and $70 \mathrm{~mm}$ formats. It was one degree sharper on 4 of the 6 panels when compared to the $35 \mathrm{~mm}$ format, and better on 3 panels when compared to the $70 \mathrm{~mm}$ format.

\section{0-FEET FLYINC HEIGHT}

At the 5000-foot flying height, the resolution of the panels on the $35 \mathrm{~mm}$ and $70 \mathrm{~mm}$ formats deteriorated and the 9 -inch format

TABle 3. Resolution Comparison for the Thres Formats (APprarance of PaNeI UNDEX 6X Magnitication). Format /FLyine Hisichts (FT).

\begin{tabular}{ccccccccccc}
\hline Panel & \multicolumn{3}{c}{$35 \mathrm{~mm}$ Format } & \multicolumn{3}{c}{$70 \mathrm{~mm}$ Format } & \multicolumn{3}{c}{ Pinch Format } \\
Size & 1000 & 3000 & 5000 & 1000 & 3000 & 5000 & 1000 & 3000 & 5000 \\
\hline 15ftsq & S & C & B & S & S & C & S & S & S \\
12ftsq & S & C & B & S & C & B & S & S & S \\
9ftsq & S & C & B & S & C & B & S & S & C \\
6ftsq & C & B & B & C & B & B & S & C & C \\
3ftsq & B & B & B & B & B & B & C & B & B \\
1ftsq & B & B & VV & B & B & B & B & B & B \\
\hline
\end{tabular}

$S=$ Sharp: $C=$ Clear, $B=$ Blurred: VV = Noe Visible 


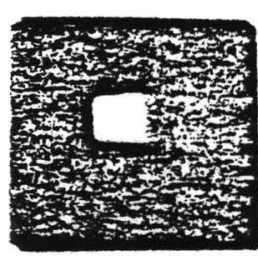

Share

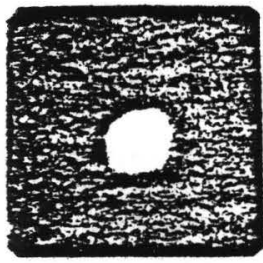

Blupred

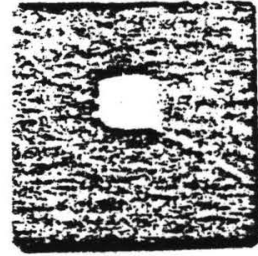

clear

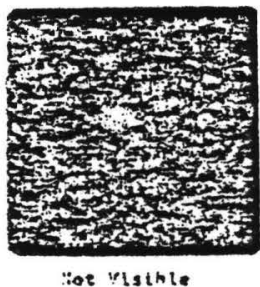

Fic. 6. Illustration of terms used to describe the resolution panels as they appeared to the individual viewing the 9 -inch, $70 \mathrm{~mm}$, and $35 \mathrm{~mm}$ photography.

was far superior to both of the smaller formats. This is illustrated in Figure $i$.

Generally, the smaller formats are adequate with respect to resolution when using flying heights of 3000 feet or less, and there appears to be little difference between the $35 \mathrm{~mm}$ and $70 \mathrm{~mm}$ formats. At flying heights above the 3000-foot level, the finch format is far superior.

\section{AIRPHOTO IVTERPRETATION COMPARISON}

The second parameter to be tested was the ease or convenience of photo interpretation with the three formats. This comparison was geared specifically to vegetation and soils interpretation for mapping purposes. The objective of the comparison was to ascertain whether the smaller formats could provide image quality so that an interpreter can identify objects of interest as weil on the $35 \mathrm{~mm}$ and $70 \mathrm{~mm}$ format as he can on the 9 -inch format.

The aid of three soils experts and fourvegetation experts was solicited. The experts individually viewed one set of stereo pairs of each format of the same general area. The stereo pairs were viewed under 4.5 magnification with the Delft Scanning Stereoscopes and the Fairchild Multi-Sensor Yiewer. A cloth cover was placed over the stereoscopes so that the interpreter could not see which format he was viewing. He then judged each format. A list of criteria related to his particular field of expertise was provided as an aid to look for specific identification features.
9 Ineh Fornat

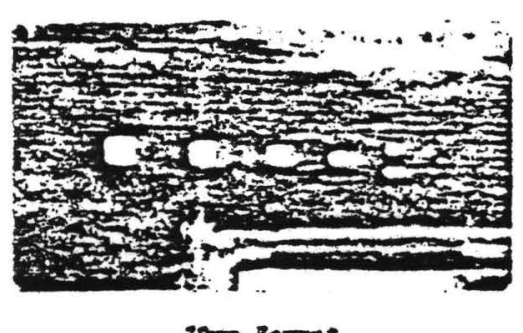

90u Porsene
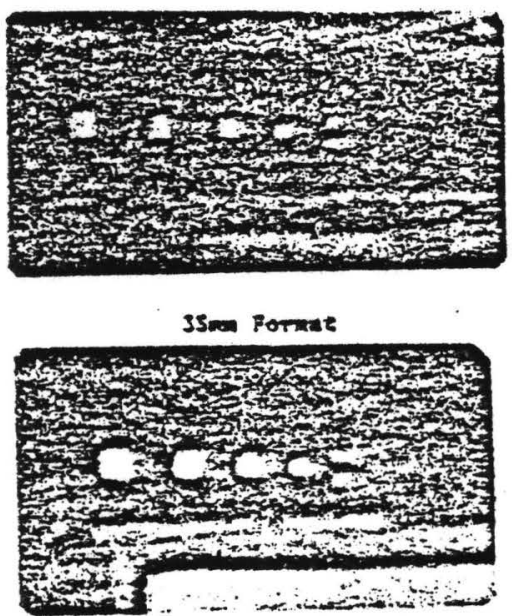

Fic. 7. Resolution panels from the ginch, $70 \mathrm{~mm}$, and $33 \mathrm{~mm}$ formats, enlarged to a common scale of about one millimeter equals five feet. To make these prints, the G-inch, $70 \mathrm{~mm}$, and $35 \mathrm{~mm}$ photos were enlarged approximately 6.6 times, 25 times, and 42 times respectively.

The lying heights of all formats were 3000 feet. Unfortunately, no $70 \mathrm{~mm}$ infrared falsecolor film was available, so normal color was used. Other qualifying aspects of this comparison were that the stereo model did not provide the identical coverage in each format (because all three cameras were not exactly synchronized). Also, two types of stereoscopes were used.

The criteria for soils interpretation included ability to interpret soil moisture, texture, color, vegetation cover, soil patterns, degree of erosion and drainage, the surround. ing terrain, the land-use of the area, and the soil location and boundary. For vegetation interpretation, criteria included vegetation patterns and colors, canopy texture, shadows, branch pattems, vegetation shape and density, crown formation, and vegetation size and texture.

Before the results of the tests were known, 


\section{PHOTOCRAMMETRIC ENGINEERINC \& REMOTE SENSING, 1975}

when the vegetation experts were interviewed and asked their preference of format size, they mentioned that the small area covered per photo with smaller-format photog. raphy was restrictive. This preconceived notion ivas dispelled when the photos were uncovered and the area coverage was shown to be nearly the same on all the formats. It was pointed out that the same area coverage can be obtained by the smaller formats as by the 9 -inch format if the correct format-to-focallength ratio is used. This image can then be enlarged. Only one of the vegetation experts was able to correctly identify the three formats prior to the photos being uncovered. When the results of this test were tabulated, all four experts had picked the $35 \mathrm{~mm}$ format as their first preference. They said that this format provided good color rendition and res. olution. From the opinions of the four knowledgeable individuals who viewed the formats, it appears that the smaller formats can in fact provide acceptable results for vegetation mapping.

The three soils experts, on the other hand, all preferred the 9 -inch format for mapping soil boundary locations. In each case they selected the $\rightarrow$-inch format as superior to the smaller formats for their work. When asked why, they stated that the sharper resolution was the determining factor. Further, they said, that for soils-mapping work the 9 -inch format was much more convenient than the smaller formats, which must be enlarged. The soil boundaries stood out much clearer on the g-inch formats than on the $35 \mathrm{~mm}$ or $70 \mathrm{~mm}$ formats. None of the soils experts correctly identified the concealed formats.

The vegetation experts were-

1. Alan Ek, Professor, Department of Forestry, University of Wisconsin.

2. Arlyn Linde, Vegetation Analysis Staff, Wisconsin Department of Natural Resources.

3. Don Thompson, Vegetation Analysis Staff, Wisconsin Department of Natural Resources.

4. Alan Rusch, Vegetation Aralysis Staff, Wisconsin Department of Natural Resources.

The soils experts included:

1. Ralph Kiefer, Professor, Deparment of Civil and Environmental Engineering, University of Wisconsin.

2. James Elliot, Materials Section, District One, Division of Highways, Wisconsin Department of Transportation.

3. Richard Robinson, Central Office, Soils Unit, Division of Highways, Wisconsin Department of Transportation.
TABle 4. Photo INTERpretation Capabillty of THE THREI Format SIzES

(SUMMarY OF INTERPRETERS EVALUATION) RATINGS (1sT, 2ND, 3RO) ASSIGNED BY THE EXPERTS.

\begin{tabular}{cccccccc}
\hline & \multicolumn{3}{c}{ Vegezation Experts } & \multicolumn{3}{c}{ Soil Experts } \\
\hline Format & 1 & 2 & 3 & 4 & 1 & 2 & 3 \\
\hline Fin & 2nd & 3rd & 3rd & 3rd & 1st & 1st & 1st \\
$70 \mathrm{~mm}$ & 3rd & 2nd & 2nd & 2nd & 2nd & 2nd & 2nd \\
$35 \mathrm{~mm}$ & 1st & 1st & 1st & 1st & 3rd & 3rd & 3rd \\
\hline
\end{tabular}

\section{Metric ACCuracy Comparison}

The objective of the metric accuracy comparison was to determine the relative accuracy of the formats in locating objects of mapping purposes. Four tests were conducted in order to provide a comprehensive analysis between the $35 \mathrm{~mm}, 70 \mathrm{~mm}$, and 9 -inch formats.

The procedure involved obtaining a base map and using it as control in rectifying and enlarging the three formats to the same scale. Measurements were then taken on the rec tified photos. The discrepancies between the measured distances and the base map distances provided the relative accuracy of the three formats. With these accuracy results, one can ascertain which format will meet his mapping accuracy needs.

A base map of the research area was first field checked and the photos then enlarged and rectified to match it. The objective of the rectifying and enlarging process was to remove the tilt error in the photographs and bring them to a desired scale. The process requires at least three control points, but usually at least four control points were used. The base map, with selected control points indicated, was placed on an easel. The negative or transparency was then placed in the rectifier-enlarger projector, and the photographic image was projected onto the base map. The scales of the projected image and map were made to coincide by enlarging or reducing the projected photograph. This was done by changing the distance between the projecting lens and the easel. The easel was then tilted and rotated so as to aligm control points on the base map to their image points on the projedted photograph. Thus, average scale of the enlarged image matched that of the base map. When sharp focus was achieved, an exposure was made resulting in a rectified photograph. This procedure was followed with each of the formats. The work was done by the Wisconsin Deparment of Transportation which has had several years experience in operating the rectifying enlarger. The resulting rectified photos are ap- 
proximately vertical photos and are all of the same scale (see Figure 4). The errors due to relief displacement still exist in the enlarged photo as well as errors due to focal plane Ilatmess and lens distortion and accidental error due to the enlarger operator. ' The original photos used were those taken from a liy. ing height of 3000 feet above terrain. Accidental operator error should be expected in all rectification processes. In this case, the error was 1 percent in the $35 \mathrm{~mm}$ and 9 -inch formats and 1.6 percent in the $70 \mathrm{~mm}$ format. This error was determined by measuring the lengths on the enlargements and the same lengths on the base map for three control points. These three control points created the control triangle shown in Figure 5 . A mean scale factor was thus determined for each photo enlargement.

TEST 1. The purpose of Test I was to determine the discrepancy between about 30 selected distances on the base map and those distances on the rectified enlargements. These 30 lines were all within the control triangle (Figure 5). The measured distances from the enlargements were adjusted by the mean scale factor described above. The adjusted length was then subtracted from the measured length of the lines on the field. checked base map. Table 5 shows the resulting discrepancies for the three formats. Surprisingly, the $35 \mathrm{~mm}$ camera system provided the least error (an error of 1.39 percent).

TEST II. To supplement and attempt to verify the conclusion of Test I, Test II was undertaken. In Test II, a scale factor was es. tablished for each of the 30 lines. An error analysis was then run on these 30 scales. Table 6 shows the results of this test. Again the $35 \mathrm{~mm}$ format provided the least error, this error being 1.49 percent

The test lines used in these first two tests were restricted to only a small portion of the format with all lines within the control
Tabli j. Results of Test l. Detrrmintinc

Discrepancies Betwezn tojusted Pyoto Distances and Base Mis Distances for 30 Lines WITHIN THE CONTROL TRLANCLE.

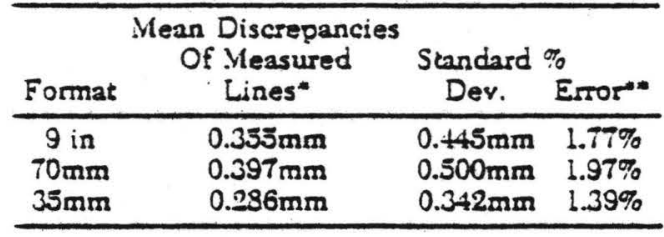

Seale of Eniargement: $\operatorname{lmm}=1+$ it.

- Mean Discrepancy - Meaa Difference in Lengrh of Adjusced Lines oa Eniargemone Compared to Base Mag.

-\% Error $=$ (.Mean Discrepancy/Miene Lengeh of Lines) $\times 100$.

triangle (see Figure 5). Test lines were not located on the perimeters of the format. By comparing enlargements it was obvious that greater error existed on the perimeters of the formats outside of the control triangle. The results of Tests I and II do indicate that within a small area of tight control, spaced within 600 feet, the smaller formats can provide just as good an accuracy in locating points as the G-inch format photography.

TEST III. Because of the obvious error around the perimeters of the rectified photos, Test III was undertaken. In Test III, the g-inch projection was used as base control and the $35 \mathrm{~mm}$ and $70 \mathrm{~mm}$ images were enlarged and compared to it. The 9 -inch projection was used as a base because no map control existed on the perimeter of the photo area. The 9 -inch enlargement was placed into the rectifier-enlarger and projected onto a Cronaflex base sheet. Four points were selected and plotted for control on the outer edges of the projected image. About 30 other points for comparison studies were plotted on the base sheet. The $35 \mathrm{~mm}$ and $70 \mathrm{~mm}$ format photographs were then rectified to both three and four control points derived from the 9 -inch photographs. The 30 comparison

Tabiz 6. Results of Test II. AMalyzing Scales of 30 Test Lines on the

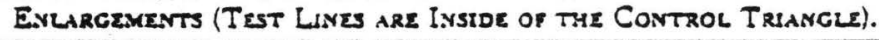

\begin{tabular}{|c|c|c|c|c|c|c|}
\hline \multirow[t]{2}{*}{ Format } & \multirow[t]{2}{*}{$\begin{array}{l}\text { Average } \\
\text { Scale }\end{array}$} & \multicolumn{5}{|c|}{ Discrepancy of Scale Factors } \\
\hline & & $\begin{array}{c}\text { Mean" } \\
\text { MM }\end{array}$ & $\begin{array}{l}\text { Standard } \\
\text { Deviation } \\
\text { MM }\end{array}$ & $\operatorname{Max}_{M}{ }^{\mu+}+"$ & $\begin{array}{c}\text { Max " -" } \\
\text { MM }\end{array}$ & $\begin{array}{l}\sigma_{0}^{* *} \\
M \mathrm{M}\end{array}$ \\
\hline $\begin{array}{c}9 \mathrm{in} \\
70 \mathrm{~mm} \\
35 \mathrm{~mm}\end{array}$ & $\begin{array}{l}1.039 \\
0.992 \\
1.009\end{array}$ & $\begin{array}{l}0.016 \\
0.020 \\
0.015\end{array}$ & $\begin{array}{l}0.023 \\
0.025 \\
0.019\end{array}$ & $\begin{array}{l}+0.046 \\
-0.057 \\
-0.058\end{array}$ & $\begin{array}{l}-0.067 \\
-0.046 \\
-0.027\end{array}$ & $\begin{array}{l}1.34 \\
2.02 \\
1.49\end{array}$ \\
\hline
\end{tabular}

- Mean Discrepancy $=$ Mean Difference in Scales Between Average Scale and Individual Scale Factors.

$\because \%$ Discrepancy $=($ Mean Discrepancyi itean Lenzeth of lines) $\times 100$ 
PHOTOCRAMMETRIC ENCINEERINC \& REMOTE SENSINC, 1975

points were plotted and the discrepancies in their locations were measured. Table 7 provides the comparison results which are in line with accepted theory of the accuracies of smaller format camera systems. It was found that the $70 \mathrm{~mm}$ format provided better results than the $33 \mathrm{~mm}$ format. It is interesting to note the differences between the discrepancies with respect to whether three or four control points were used in the rectifying process and whether the test points lie within or outside the controlled area. Points within the controlled area, on enlargements rectified with four control points, yielded the best accuracies. Ground positions of points located with the $70 \mathrm{~mm}$ format were about 6.5 feet from the point's location as determined by the finch format. The $35 \mathrm{~mm}$ format was in error by about 11 feet, assuming the 9 -inch format point locations were correct. Most environmental mapping requirements are in the neighborhood of tens of feet. This accuracy can be met easily with the smaller formats.

TEST IV. Field personnel compiling vegetation and soils maps don't always have available sophisticated rectifying equipment; therefore, an additional comparison was conducted projecting a mounted $35 \mathrm{~mm}$ slide onto the base map using a standard carousel type $35 \mathrm{~mm}$ slide projector. The image was displayed on an upright easel screen mounted on a table with a rotating top. Figure 2 illustrates the process using a $35 \mathrm{~mm}$ micro-film viewer. The image was rectified using three control points located on the outer edges of the format, and test points were plotted on the base sheet. Table 8 pro vides the results, which indicate that a point can be located within 8 feet of its correct position (correct position as derived from the F-inch format photo).

The results of Test IV are superior to those of Test III. This is party explained by the fact that the original exposure was used in Iest IV as opposed to a reproduced enlarged transparency in which the resolution had deteriorated.

The results of these four tests indicate that small formats can provide metric accuracy of
Table 7. REsults of Test III Small Format

projected Imaces Compared to ginch Base ENLARCEMENT.

Rectification Using Three Control Points

\begin{tabular}{ccccccc}
\hline $\begin{array}{c}\text { Format } \\
\text { Test Points } \\
\text { Inside } \\
\text { Control Area }\end{array}$ & $\begin{array}{c}\text { Test Points } \\
\text { Outside } \\
\text { Control Area }\end{array}$ & $\begin{array}{c}\text { All Points } \\
\text { In \& Outside }\end{array}$ \\
\hline $\begin{array}{c}\text { Mean } \\
\text { mm }\end{array}$ & $\begin{array}{c}\text { SD } \\
\mathrm{mm}\end{array}$ & $\begin{array}{c}\text { Mean } \\
\mathrm{mm}\end{array}$ & $\begin{array}{c}\text { SD } \\
\mathrm{mm}\end{array}$ & $\begin{array}{c}\text { Mean } \\
\mathrm{mm}\end{array}$ & $\begin{array}{c}\mathrm{SD} \\
\mathrm{mm}\end{array}$ \\
\hline $70 \mathrm{~mm}$ & 2.07 & 1.13 & 4.70 & 1.56 & 3.00 & 1.8 \\
\hline
\end{tabular}

Rectification Using Four Control Points

\begin{tabular}{lllllll}
\hline $70 \mathrm{~mm}$ & 2.00 & 0.75 & 3.00 & 1.58 & 2.20 & 1.06 \\
$35 \mathrm{~mm}$ & 4.71 & 3.87 & 3.34 & 1.61 & 3.86 & 245 \\
\hline
\end{tabular}

Scale $=1 \mathrm{~mm}$ on Buse Sheet $=3.2 \mathrm{Ft}$. on the Cround

tolerable limits for vegetation, soils, and other environmental mapping. The tests using the field-checked base map conclude that points within a small controlled area will be located as accurately with the smaller formats as with the 9 -inch format. The tests using 5000 foot photography and the $F$-inch photo as a base and locating the control on the perimeter of the photo show that points can be located to within about ten feet with the smaller formats (assuming the points located with the 9 -inch photographs are correct). As indicated from the results of Test IV, using a slide projector to transfer environmental data yields as accurate results as with a rectifierenlarger. This information is helpful to those conducting small scale research where large facilities and sophisticated equipment are not available.

Errors inherent in photographic analysis do qualify the findings of these tests. As previously indicated there was about 1 percent error between the base map and the rectified linch photographs. The base map also has an error of about 0.1 percent as compared to ground control. The points included both topographic and planimetric features, and relief displacement will distort the results. Because of deterioration in resolution of the smaller formats, point locations may not be

\begin{tabular}{|c|c|c|c|c|c|c|}
\hline \multirow[t]{2}{*}{ Format } & \multicolumn{2}{|c|}{$\begin{array}{c}\text { Test Points } \\
\text { Outside Control } \\
\text { Area }\end{array}$} & \multicolumn{2}{|c|}{$\begin{array}{c}\text { Test Points } \\
\text { Inside Control } \\
\text { Area }\end{array}$} & \multicolumn{2}{|c|}{ All Points } \\
\hline & Mean & $S D$ & Mean & $S D$ & Mean & SD \\
\hline $35 \mathrm{~mm}$ & $1.91 \mathrm{~mm}$ & $1.38 \mathrm{~mm}$ & $0.825 \mathrm{~mm}$ & $0.52 \mathrm{~mm}$ & $1.61 \mathrm{~mm}$ & $1.19 \mathrm{~mm}$ \\
\hline
\end{tabular}


exact. Control points used in the rectification process in every case were not sharp and distinct points; therefore, coincidence in rectification may be an error. Measuring errors and paper and film shrinkage also contribute to errors in this comparison.

\section{Cost ANalysis}

Based on the assumption that to do optimum environmental mapping, simultaneous photography with color and color infrared film is required, the costs of such F-inch, $70 \mathrm{~mm}$, and $35 \mathrm{~mm}$ camera systems were analyzed. A two-camera system was investigated for each format. With the 9 -inch camera system only one focal length lens was considered. This had 6-inch lenses which could be classified a "normal" focal length lens. For the $70 \mathrm{~mm}$ and $35 \mathrm{~mm}$ formats, however, the costs of not only normal focal length lenses but also wide angle and telephoto lenses were included. For a two-camera system for the -inch format a relatively large aircraft with two camera ports is required while the $70 \mathrm{~mm}$ and $35 \mathrm{~mm}$ camera systems a smaller aircraft with one "camera port" will suffice. The difference in initial cost and cost of operation of the different types of aircraft, although very important, is not included in the analysis.

The different format photos can be handled and viewed by various methods. These different means of transferring the photo data onto the base map will be discussed but no actual dollar values will be attached to the different systems. Generally speaking, the projection systems for the larger format sizes are more expensive.

\section{NTNE $X$ NINE INCH BORMATS}

For simultaneous photography with the s-inch format, two cameras are required. The cost figures given are for a Wild RC 10 camera system:

\begin{tabular}{lr} 
Two Camera Cost & $\$ 60,000$ \\
Two Lenses & 30,000 \\
Two Filters & 3,000 \\
Intervalometer & 8,000 \\
\hline Total Cost & $\$ 101,000$
\end{tabular}

Cost per simultaneous exposure on color and color IR film:
$2 \times$ Film
$2 \times$ Development
$2 \times$ Transparency
$2 \times$ Prints
Total Cost

$\$ 1.37$

1.36

8.38

6.40

$\$ 17.51$
The advantage of the 9 -inch system is that it gives greater resolution. The lenses are specifically designed to eliminate lens distortion. Focal piane flatness is assured by a vacuum sucking the film lat against the focal plane. The disadvantage of the system is the high cost of equipment and high operational costs. A large aircraft is required to carry the two cameras. Viewing for photo interpretation can be done with conventional stereoscopes, and stereoplotters. Transfer of environmental data to a base map can be accomplished with a zoom transfer scope, a sketchmaster, a Qby-Q-inch rectifying enlarger, or by tracing onto a piece of transparent material laid directly over the photo and then enlarging this transparency to match the scale of a base map. Nine-inch photography can be obtained by contract from aerial photography firms but differential film costs alone can pay tor the small format system. For example, an aerial photography mission of one light line requiring 100 color and 100 color infrared exposures could cost from $\$ 2500$ to $\$ 3000$. Vost firms do not have two 9 -inch format cameras, making simultaneous coverage unlikely. Although numerous variables affect the costs, one can see the cost savings involved with smaller format systems.

\section{MM SYSTEM}

The cost analysis is made for a two-camera Hasselblad system of the type described by Malar and Rinker but with two cameras instead of four:

$$
\begin{aligned}
& \text { Cost of Cameras-2 Hasselblad } \$ 1,500 \\
& \text { Lens: } \\
& 2 \times \text { normal } \\
& 2 \times \text { wide angle } \\
& 2 \times \text { telephoto } \\
& \text { Filters } \\
& \text { Intervalometer } \\
& \text { Other aerial accessory equipment } \\
& \text { (Bulk magazine, cassettes, }
\end{aligned}
$$
$2 \times$ film
$2 \times$ development
$\$ 0.15$
2x transparency
0.42
$2 x$ print
1.64
Total cost
\$ 2.85

The advantage of the $70 \mathrm{~mm}$ system is that the resolution is still quite good. Film in color 


\section{PHOTOGRAMMETRIC ENGINEERINC \& REMOTE SENSING, 1975}

and color IR is readily available. The disad. vantage of this system is that the film is not held flat in the focal plane and that the lenses are made primarily for image sharpness rather than for metric accuracy. The photos can be viewed in 3D with zoom stereoscopes. Environmental data can be transferred from the photo to a base map with a zoom transfer scope, or with a rectifying enlarger or a strip film projector. Although $70 \mathrm{~mm}$ strip film projectors are made, they are not very common. The $70 \mathrm{~mm}$ film can be cut and mounted onto 2 -inch slides to use with 2-inch slide projectors which are obtainable but are not extremely popular. With any of the projection methods the image can be projected to match a transparent base map mounted on a rear projector screen. When the projected image is made to match the scale of the base map, the environmental data on the projected image can then be traced onto the base map.

\section{MM FORMAT}

The cost analysis on the $35 \mathrm{~mm}$ system is made for the Nikon $F 2$ camera. Robot and Canon cameras were also investigated.

$$
\begin{array}{lc}
\begin{array}{l}
\text { Cost of Camera } \\
2 \text { Nikon Motormetric }
\end{array} & \$ 2,400 \\
\text { Lenses: } & 1,900 \\
2 \times \text { normal } & \\
2 \times \text { wide angle } & \\
2 \times \text { telephoto } & 12 \mathrm{ea} \\
\text { Filters } & 300 \\
\text { Intervalometer } & \\
\text { Other aerial accessory equipment } \\
\text { (Bulk magazine, cassettes, } \\
\begin{array}{l}
\text { batteries, bulk film loader, } \\
\text { recharge unit, etc.) }
\end{array} \\
\begin{array}{ll}
\text { Total Cost } & 1,800 \\
\hline 6,000
\end{array}
\end{array}
$$

The developed film can be handled like standard microfilm and viewed in a variety of $35 \mathrm{~mm}$ viewers and projectors.

Another important aspect of the $35 \mathrm{~mm}$ system is that it can be used to photograph at close range a data sheet at the beginning of each project or during light so later on the film is not mis-identified. This is similar to what is done in the movie industry at the beginning of each sec, or in microfilming at the beginning of each new series of articles.

The disadvantage of this format is that, like the $70 \mathrm{~mm}$ format, the lenses are primarily designed for image sharpness rather than metric accuracy. There is no vacuum to assure focal plane flatness. The $35 \mathrm{~mm}$ format has poorer resolution than the larger formats. Also at this stage of operation little $35 \mathrm{~mm}$ color infrared film is sold in bulk and it must be specially ordered in large quantities from the factory.

Although overlapping $35 \mathrm{~mm}$ photos can be viewed in $3 D$ by some zoom stereoscopes, $35 \mathrm{~mm}$ film is primarily viewed nonstereoscopically on $35 \mathrm{~mm}$ microfilm readers. Two such viewers side by side can be nicely used to view both color and color infrared film." With the $35 \mathrm{~mm}$ Kodak Motormatic Microfilm Viewer the viewing screen can be taken off and the image can be projected directly onto a rear projection screen which can be moved to different distances from the view. er and tilted so that the projected image can be matched to the base map (see Figure 2). The environmental data can then be traced onto the base map. This is similar to the rectification process except that the desirable data is manually transferred and no photographic enlargement is made. If desired the film can also be copied with $35 \mathrm{~mm}$ slide copiers or made into $35 \mathrm{~mm}$ slides and projected in the same way.

\section{Conciusion} infrared photos:
$2 \times$ film
$2 \times$ development
$2 \times$ transparencies
$\$ 0.04$
0.18
$2 \times$ print
0.36
Total Cost
s 0.80

The advantages of this system are that it is the least expensive in equipment and operation, the lightest in weight, and the most versatile. Aso a two-camera bank can be hand held. ${ }^{7}$ Various focal length lenses can be put on easily and quickly exchanged. The $35 \mathrm{~mm}$ format is the universal format not only for microfilm but also for commercial moving picture film. Most film acquisition, processing and production is readily accomplished.
The objective of this investigation was to analyze 9 -inch, $70 \mathrm{~mm}$, and $35 \mathrm{~mm}$ format photography with respect to resolution qual. ity, photo interpretation capability, medric accuracy, and cost. The application in mind was for environmental mapping. For such work it was assumed that both color and color infrared photography was highly desirable and that a two-camera system was the best method for obtaining the required photography.

For the analysis an area of environmentai interest to the Wisconsin State agencies was flown at different flying heights with $\vartheta$-inch, $70 \mathrm{~mm}$, and $35 \mathrm{~mm}$ photography. The area had a variety of soils, vegetation, and water types. 
Resolution panels and ground control were also located in the area.

The results of these investigations indicate that small format camera systems can in fact play a key roie in environmental mapping. The resolution comparison showed the superior quality of the Ginch format at higher Ilying heights. At llying heights of about 1000 feet the resolution of the three formats seemed equally satisfactory. Both the $35 \mathrm{~mm}$ and $70 \mathrm{~mm}$ camera systems provided nearly the same resolution quality at each flying height tested. The air-photo interpretation comparison revealed that for soils mapping the smaller formats were less desirable while for the vegetation mapping comparison the smaller formats were preferred. The metric accuracy tests using a rectifier-enlarger showed that within small tightly controlled areas the smaller formats provided just as accurate point locations as the 9 -inch format. However, when control is on the perimeter of the photograph, errors of about 10 feet can be expected with the smaller formats at lying heights of 5000 feet. The $35 \mathrm{~mm}$ images were also projected utilizing a slide projector, and metric accuracy results were better than with the restifying enlarger.

Costs analyses were made for 9 -inch, $70 \mathrm{~mm}$, and $35 \mathrm{~mm}$ camera systems capable of obtaining simultaneous color and color infrared photography. The costs of such systems are about $\$ 100,000$ for the 9 -inch format. with the standard lenses; and $\$ 7,500$ and $\$ 6,000$ respectively for the $70 \mathrm{~mm}$ and $35 \mathrm{~mm}$ systems including auxiliary lenses. Without the auxiliary lenses these small format sys. tems can cost as little as 33,500 . The cost of film and processing is about nine times greater with the g-inch system. The savings in cost of photos alone between the 9 -inch and the smaller format systems will pay for the smaller format systems within only several hundred to a few thousand photographs.

An additional factor that requires consideration is the convenience of use of the different format systems. For stereo viewing the g-inch format is preferrable with the $70 \mathrm{~mm}$ more desirable than the $35 \mathrm{~mm}$ format. How. ever, for flling, indexing, retrieving, projecting, and simultaneous viewing of different frames, the $35 \mathrm{~mm}$ is preferred. A marked ad. vantage of the $35 \mathrm{~mm}$ format over the $70 \mathrm{~mm}$ format is its compatibility with $35 \mathrm{~mm} \mathrm{mi}$ crofilm viewing and film handling equipment. The $70 \mathrm{~mm}$ viewing equipment is expensive and difficult to procure. For projecting onto a base map for transferring environmental data the $35 \mathrm{~mm}$ format equipment is easily obtained and easy to use. Both the $70 \mathrm{~mm}$ and
$35 \mathrm{~mm}$ camera systems are light weight, versatile, and easy to operate and emplace for aerial application. A variety of lenses can be obtained and easily changed during aerial operations.

The results of this comparison provide a relative quality and cost standard of the three camera systems, providing the user a basis from which to make sound decisions. The accuracy requirement of environmental mapping is in the magnitude of tens of feet. Small format systems can provide such an accuracy, and their initial and operating costs are about $1 / 10$ the cost of 9 -inch mapping camera systems. For those engaged in environmental mapping it is recommended that they closely look at the small format camera systems, specifically the $35 \mathrm{~mm}$ system, to ascertain which system can provide their mapping needs at the least cost.

\section{ACXNOWLDGMENTS}

Sincere appreciation is extended to Vern Schult and John Haverberg and all the other members of the Wisconsin Department of Transportation and Department of Natural Resources and the crew of the DC3 whose support and effort made this overall project possible; to NASA for support under Grant NGL 50.002.127 for Multidisciplinary Research in Remote Sensing at the University of Wisconsin; to Professor James L. Clapp and his staff for their administrative work; to Jean Clegg for her help on making and emplacing the resolution panels several times until a successful overflight was accomplished; to Richard Pearsall who took and coordinated the aerial photography; and to Larry Christenson who performed the base map field check.

\section{REFERECES}

1. Scherz, James P., "Errors in Photogrammet. ry," Photogrammetric Engineering, Vol. XI No. 4, April, 1974.

2. Strandberg, Cal H.,35MM Aerial Photography for Measurement Anclysis Presentation, U.S. Public Health Service-Division of Water Supply and Pollution Control-Demonstration Grant IVPD 20-01-1963, 1963.

3. Mariar, Thomas K., and J. N. Rinker, "A Small Four Canera System for Multi Emul. sion Studies," Photogrammetric Engineering. Vol. XXXIII, No. 11, November, 1967.

4. Klooster, Steven A., and James P. Scherz, "Water Quality of Photographic Analysis," Photogrammetric Engineering. Vol. XXXIII, XI. No. 8, August, 1974.

5. Ishaq, Achi, M., “Application of Remote Sensing to the Location of Hydrologically Active Source Areas," Ph.D. Thesis, University of 
Wisconsin, Madison, Wisconsin December. 1974.

6. Scherz, James P., "Remote Sensing Considera. tions for Water Quality Monitoring." Proceedings of Seventh International Symposium on Remote Sensing of Environment, 17.21 May, 1971, Ann Arbor, Michigan.

7. Rinehardt, Gregory L, and James P. Scherz, "A 35MM Aerial Photographic System," Procredings of the 38th Annual Meeting of the American Society of Photogrammetry, Washington, D.C., March, 1972.

8. Singh, Ramchandra, and James P. Scherz, "A
Catalog System for Remote Sensing Data." Photogrammetric Engineering, Vol. XI No.6. June, 1974.

9. Gustarson T. D. and M. S. Adams, "Aerial Photography as a Quantitative Tool for the Investigation of Aquatic Ecosystems," Proceed. ings of Symposium, "Remote Sensing for Water Resources Management" by: American Water Resources Association, Burlington, Ontario, Canada, June $11-14,1973$.

10. Wolf, Paul R., Elements of Photogrammetry, (New York: McGraw-Hill Book Company, 1974), pp. 57.58, 272-275.

\section{Notice to Contributors}

1. Manuscripts should be typed, doublespaced on $8 \$ \times 11$ or $8 \times 10 t$ white bond, on one side only. References, footnotes, captions-everything should be double-spaced. Margins should be $1 \frac{1}{2}$ inches.

2. Ordinarily two copies of the manuscript and two sets of illustrations should be submitted where the sec ond set of illustrations need not be prime quality; EXCEPT that five copies of papers on Remote Sensing and Photointerpretation are needed. all with prime quality illustrations to facilitate the review process.

3. Each article should include an ab- stract, which is a difest of the article. An abstract should be 100 to 150 words in length.

4. Tables should be designed to fit into a width no more than five inches.

5. Illustrations should not be more than twice the final print size: glossy prints of photos should be submitted. Letter. ing should be neat, and designed for the reduction anticipated. Please include a separate list of captions.

6. Formulas should be expressed as simply as possible, keeping in mind the diffculties and limitations encountered in setting type.

\section{Joumal Staff}

Editor in Chief, Dr. James B. Case

Newsietter Editor, M. Charlene Gill

Advertising Manager, Wm. E. Harmen, Jr. Managing Editor, Clare C. Case

Associate Editor, Remote Sensing \& Interpretation Division, Dr. Roger M. Hoffer Associate Editor, Photography Division, Abraham Anson

Associate Editor, Photogrammetric Surveys, H. M. Karcto

Cover Editor, Jomes R. Shepard

Engineering Reports Editor Gordon R. Heath

Chaiman of Article Review Board. Lawrence W. Fritz

Editorial Consultant, G. C. Tewinkel 
(Intentionally left blank)

81 
SMALL FORMAT AERIAL PHOTOGRAPHY:

\section{A SELECTED BIBLIOGRAPHY}

U.S. GEOLOGICAL SURVEY

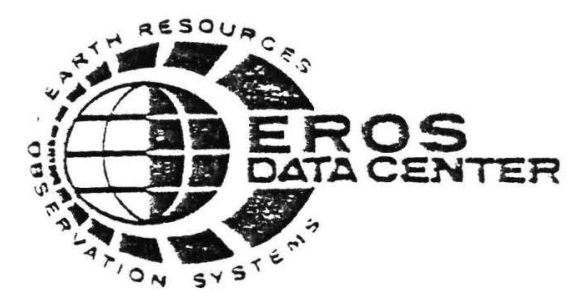




\section{SMAII FORMAT AERIAL PHOTOGRAPEY}

\section{Introduction}

There are many examples of the usefulness of aerial photographs in natural resource investigations. Unfortunately, suitable aerial photographs are not always available, and contracting for new aerial photographs to be flown by a commercial aerial survey firm can be expensive, especially for relatively small areas such as a single farm, a 100-acre wetland tract, or a city park. Do-it-yourself aerial photography using small format cameras (typically 35m) has been shown to be a viable alternative in many instances, providing valuable aerial photographs on a cost-effective basis.

This bibliography has been prepared to direct the reader to sources of information about successful applications of small format aerial photographs. It is by to means exhaustive, but serves to illustrate typical methods, materials, and analysis procedures in a number of application areas.

To facilitate access to items of limited distribution, the EROS Data Center Library call number has been included as part of the citation. Other items are found in technical journals of wide distribution. 


\section{REFERENCES}

Aeilts, David, 1976, Aerial photography: A space age farm and ranch tool for space age farmers and ranchers: Dakota Farmer, May 1976, p. 32-36 (EDC call aumber 264.Ae34a).

Benefits and techniques for low-altitude 35 aerial photography are discussed in short overview fashion along with cost considerations.

Benton, A. R., et al., 1976, Low-cost aerial photography for vegetation analysis: Journal of Applied Photographic Engineering, v. 37 , по. 1, p. 46-49.

Description of an economical approach to gathering information about vegetation resources using color-infrared film in a twin 70 m camera system. Several case studies are presented.

Clegg, R. E., and Scherz, J. P., 1975, A comparison of 90-inch, 70 m and 35 cameras: Photogrametric Engineering and Remote Sensing, จ. 41, Do. 12, p. 1487-1500.

Compares resolution, photo interpretation potential, and accuracy of 70 and 35 camera systems. A cost comparison of the two camera systems for obtaining simultaneous color and color-infrared photography is evaluated.

Eastman-Kodak Company, 1971, Photography from light planes and helicopters: Rochester, N.Y., Kodak publication no. M-5., Cat. 1475144 , $24 \mathrm{p}$. Illustrations, charts, and graphs for low-altitude oblique photography are given. Differences between aerial and ground photography are discussed briefly.

Fisher, J., and Steever, E., 1973, 35 Quadricamera: Photogrametric Engineering, v. 39, no. 6, p. 573-578.

Description of a four-camera system for studies of shorelines, marshlands, estuaries, and harbors. Designed around the Robot 35 m. camera system.

Grumstrump, P., and Meyer, M. P., 1977, Applications of large-scale 35 m color and color-infrared aerial photography to analysis of fish and wildife resources on disturbed lands: University of Minnesota Remote Sensing Laboratory, St. Paul, IN, 46 p. (EDC call number 264.G923a.)

A 35 motordrive aerial camera system with an exterior sidemount for small aircraft was tested over surface mines in Virginia. A number of film/filter/scale/altitude configurations and photointerpretation techniques were investigated. 
Hall, W. B., and Walsh, T. H., 1977, Color oblique stereo aerial (COSA) photographs for planning rapid geologic reconnaissance and other types of geologic programs: 1977 Wyoming Geological Association Guidebook, p. 741-760 (EDC call number 264.H149c).

An excellent technique sumary of the equipment and procedures used to take oblique stereo aerial photographs from light aircraft. Provides examples from the field of geology, but techniques discussed are applicable to natural resource survey as well.

Kiefer, R. W., 1970, Effects of date of photography on airphoto interpretation using color and color-infrared films, in Ghosh, S. R., editor, Proceedings of the International Symposium of Photography and Navigation: International Society of Photogrammetry, Commission I: Columbus, Ohio, May 20-28, p. 1000-1117 (EDC call number 530. . $542 e$ ).

Discusses a research project involving repetitious color and colorinfrared 35 aerial photography over an agricultural area in southern Wisconsin. Optimum dates of photography are proposed for different interpretative uses, such as soil studies, crop vigor assessment, and general agricultural management.

Klein, H. W., 1960, Mini-aerial photography: Journal of Forestry, v. 68, по. 8, p. 475-478.

Brief description of forestry applications of 35 m color aerial photographs.

Marlar, T. L., and Rinker, J. M., 1967, A small four-camera system for multi-emulsion studies: Photogrammetric Engineering, v. 33, no. 11, p. 1252-1257.

Describes a system that could be assembled from comercially available items to provide a simple, economical 4-camera system that would simultaneously expose four different emulsions.

Meyer, M. P., 1973, Operating manual-Montana 35 aerial photography systems (1st Revision): University of Minnesota Remote Sensing Laboratory, St. Paul, MN, 24 p. (EDC call number 540.M5750). Description of a 35 camera system used for resource photography including discussions about films, filters, and lenses, camera mount construction, Elight preparation operations, and slide preparations.

Meyer, M. P., and Gerbig, B. H., 1974, Remote sensing applications to forest and range resource surveys and land-use classification on the Malta District (BIM) Montana: University of Minnesota Remote Sensing Laboratory, St. Paul, MN, 36 p. (EDC call number 540.M575r). A feasible study concerning the use of 35 mn color infrared aerial photographs for monitoring vegetation trands, pests, wildlife habitat, and disease. Also deals with conventional aerial photo interpretation, mapping technique, and the utility of satellite data. 
Miller, W. A., 1974, Application of the 35 aerial photography system to resource management on National Reserve lands: Western International Commission for Higher Education, Boulder, CO, 50 p. (EDC cal1 number 854.M619a). Sumary report on how the 35 system can be used to provide a high quality, permanent photographic record to assist in monitoring resource programs; examples include inventory of surface resources, rangeland wildife habitat, forestry, watershed, mineral exploration, and surface protection.

Milfred, C. J., and Kiefer, R. W., 1976, Analysis of soil variability with repetitive aerial photography: Journal of the Soil Science Society of America, v. 40, p. 553-557 (EDC call number 560.M598a). Discusses how repetitive 35 m aerial photographs can be used to help identify and evaluate variations within soil mapping units especially as the variations relate to differences in crop growth and yield.

Rhody, B., 1976, A new, yersatile stereo camera system for large-scale helicopter photography of forest resources in central Europe: Photogrametria, v. 32, no. 5, p. 183-197. Description of a 70 twin camera system for large scale stereo photography. Details for the construction of an adjustable camera mount are given. Applications of the system for species identification, tree height, stem diameter measurements, and assessment of tree quality are presented. The system can be adapted to fixed-wing aircraft.

Rinehard, G. I., and Sherz, J. P., 1972, A 35 m aerial photographic system: Institute for Environmental Studies, Remore Sensing Program, The University of Wisconsin, Report number 13, 13 p. (EDC call number 264.R472t).

Describes a 35 system utilizing two motor-driven Nikon cameras Several operational problems are presented. A discussion on applications in water quality, vegetation and resource evaluation is included.

Sabins, F. F., 1973, Aerial camera mount for 70 m stereo: Photogrametric Engineering, v. 30, no. 6, p. 579-582. Description of a single camera mount, accessories, and a procedure whereby high quality aerial stereophotos can be obtained.

Scheirerl, R., and Meyer, M., Evaluation and imentory of waterfowl habitats of the Copper River Delta, Alaska, by remote sensing: University of Minnesota Remote Sensing Laboratory, St. Paul, IN, 46 p. (IDC call number 505.Sch25e).

Test of a 35 aerial photography system on the Copper River Delta, Alaska, to monitor waterfowl habitat and related vegetation and hydrologic changes. The 35 aerial photography system was found to be practical as a resource monitoring tool from the standpoint of 
resource data collection capabilities, modest cost of operation, and operational feasibility.

Strandberg, C. H., 1963, 35 aerial photography for measurement, analysis, presentation: T.S. Public Health Service, Division of Water Supply and Pollution Control: Demonstration Grant WPD 20-01-1963, 55 p. (EDC call number 085.St81t).

Problems in aerial photography including haze, aircraft speed, time of day, season, and effects of cloud cover are evaluated. A guide to 35 equipment is given along with a discussion of applicable interpretation techniques.

Woodcock, W. E., 1976, Aerial reconnaissance and photogrammetry with small cameras: Photogrametric Engineering and Remote Sensing, v. 42, nо. 4, p. 503-511.

Description of 35 and 70 cameras, film, aircraft, and camera mounts that can be used to acquire inexpensive reconnaissance aerial photography.

Zsilinsky, V. G., 1968, Supplemental aerial photography with miniature cameras: text of paper presented to Comission 4 at the 1lth Congress of the International Society of Photogrametry, Lausanne, Switzerland, 14 p. (EDC call number 264.28s).

An excelient guide to the technical aspects of taking, printing, and viewing of vertical 35 aerial photographs. 